DEPARTMENT OF THE INTERIOR

NITED STATES GEOLOGICAI, SURVEY

BEORAE OTTE PUTTE, DIRITOA

WATER-SUPPLY PAPER 245

\title{
MLE WATER SUPPLY OF THE UNITED STATES
}

$1907-8$

ART V. TPPER MISSISSIPPI RIVER ANI HUDSON BAT BASINS

PARED CNDER THE DIRECTION OF M. O. IEIGHTON

BX

A. H. HORTON, E. F. CHANDLER AND R. H. BOLSTER

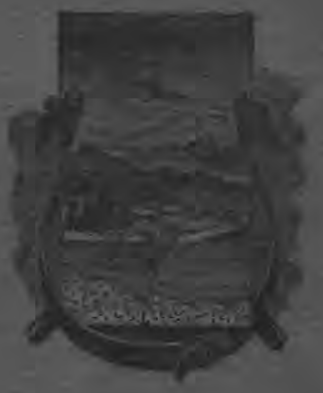

WASHINGTON

AOVERNMENT PRINTINGEOEFTOE 1910 
DEPARTMENT OF THE INTERIOR

UNITED STATES GEOLOGICAL SURVEY

GEORGE OTIS SMITH, DIRECTOR

WATER-SUPPLY PAPER 245

\title{
SURFACE WATER SUPPLY OF THE UNITED STATES
}

$1907-8$

\author{
PART T. IPPER MISSISSIPPI RITER AND \\ IIUDSON BAY BASINS
}

PREPARED UNDER THE DIRECTION OF M. O. LEIGHTON

BY

A. H. HORTON, E. F. CHANDLER AND R. H. BOLSTER

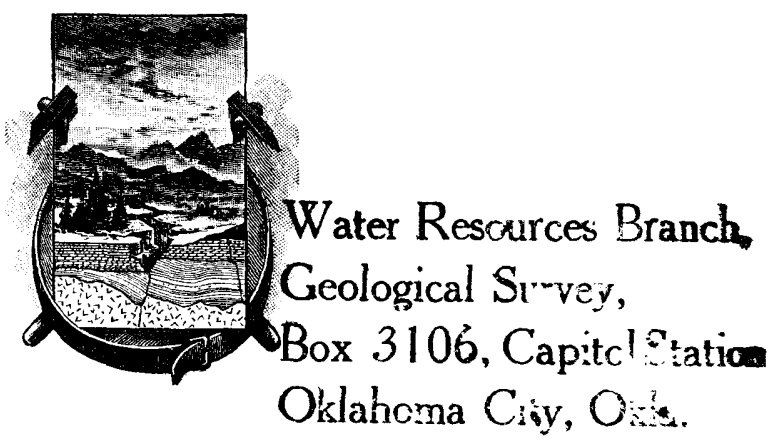

WASHINGTON

GOVERNMENT PRINTING OFFIOE

1910 


\section{CONTENTS.}

Introduction.................. P’age.

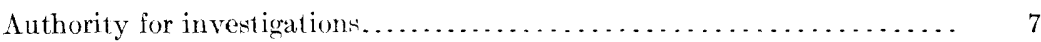

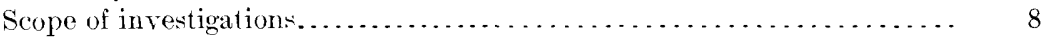

Purposes of the work ...................................... 9

Publications............................................. 10

Definition of terms......................................... 13

('onvenient equivalents.................................... 14

Explanation of tables........................................ 15

Field methods of measuring stream flow........................... 16

Office methods of computing and studying discharge and run-off......... 21

Acruracy and reliability of field data and comparative results........... 26

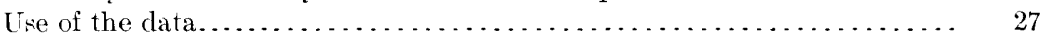

('ooperation and acknowledgments............................ 28

Division of work . . . . . . . . . . . . . . .

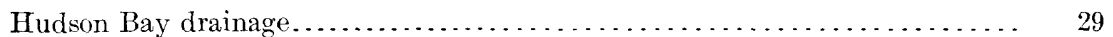

General features........................................ 29

St. Mary River drainage basin ................................ 29

Description .......................................... 29

St. Mary River near Babb, Mont........................... 30

St. Mary River near (ardkton, Alberta....................... 33

Swiftcurrent ('reek near Babb, Mont........................ 35

Red River drainage basin................................. 38

Description......................................... 38

Ottertail River near Fergus Falls, Minm...................... 41

Red River at Fargo, N. Dak............................ 44

Red River at Grand Forks, N. Dak..................... 46

Sheyenne River at Haggart, N. Dak ...................... $\quad 50$

Devils Lake at Devils I.ake, N. Dak....................... 51

Red lake River at (rookston, Min11....................... 54

Pembina River at Neche, $\mathrm{X}$. Dak ........................ 57

Mouse River at Minot, N. Dak.......................... 60

Evaporation at Lniversity, N. Dak........................ 64

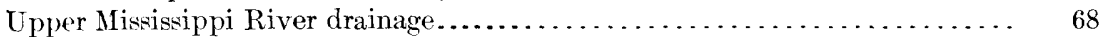

General description......................................... 68

Mississippi River at Anoka, Minn........................... 71

Chippewa River drainage basin ............................ $\quad{ }_{72}$

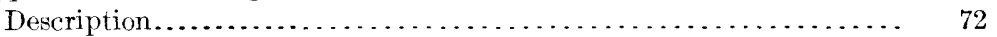

Flambeau River survey ............................... $\quad 74$

Chippewa River at Chippewa Falls, Wis.................... 74

Chippewa River near Eau (laire, Wis........................ $\cdot 83$

Red Cedar River at Menominee, Wis...................... 85 
Upper Mississippi River drainage-Continued.

Black River drainage basin. ........................... 88

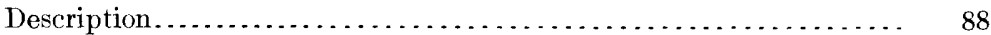

Black River survey............................... 89

Black River at Neillsville, Wis......................... 89

Wisconsin River drainage basin . . . . . . . . . . . . . . . . . . . . . . 92

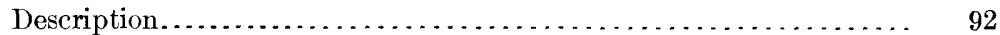

Wisconsin River survey $\ldots \ldots \ldots \ldots \ldots \ldots \ldots \ldots \ldots \ldots \ldots \ldots \ldots \ldots \ldots$

Eau Claire River survey............................. 94

Wisconsin River near Rhinelander, Wis.................... 94

Wisconsin River at Merrill, Wis......................... . 97

Wisconsin River near Necedah, Wis....................... 100

Wapsipinicon River drainage basin . . . . . . . . . . . . . . . . . . . 102

Description......................................... 102

Wapsipinicon River at Stone City, Iowa................... 103

Rock River drainage basin . . . . . . . . . . . . . . . . . . . . . . . 103

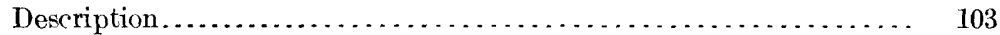

Rock River at Rockton, Ill.......................... . 105

Iowa River drainage basin . . . . . . . . . . . . . . . . . . . . . . 107

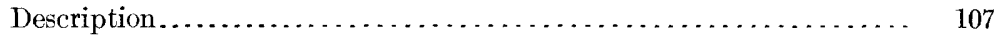

Cedar River at Cedar Rapids, Iowa...................... 108

Sangamon River drainage basin . . . . . . . . . . . . . . . . . . . . . 110

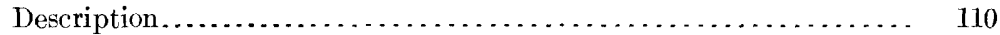

Sangamon River at Monticello, Ill . . . . . . . . . . . . . . . . . . . . 112

Sangamon River at Riverton, Ill........................ 113

Sangamon River near Chandlerville, Ill . . . . . . . . . . . . . . . . . 114

South Fork of Sangamon River near Taylorville, Ill. . . . . . . . . . . 115

Salt Creek near Kenney, Ill........................... 116

Kaskaskia River drainage basin. . . . . . . . . . . . . . . . . . 117

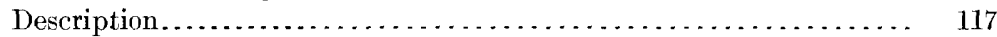

Kaskaskia River near Arcola, Ill . . . . . . . . . . . . . . . . . . . 118

Kaskaskia River at Shelbyville, Ill . . . . . . . . . . . . . . . . . 118

Kaskaskia River at Vandalia, Ill.......................... 119

Kaskaskia River at Carlyle, Ill........................ 121

Silver Creek near Lebanon, Ill........................... 122

Big Muddy River drainage basin. . . . . . . . . . . . . . . . . . . . . . . . 123

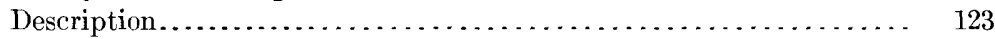

Big Muddy River near Cambon, Ill ....................... 124

Beaucoup Creek near Pinckneyville, Ill . . . . . . . . . . . . . . . 125

Miscellaneous measurements in Hudson Bay and upper Mississippi River drainages ............................................ 126

Miscellaneous measurements in St, Mary River drainage basin . . . . . . 126

Miscellaneous measurements in Red River drainage basin . . . . . . . . 126

Miscellaneous measurements in Wisconsin River drainage basin . . . . 126

Summary of mean discharge per square mile . . . . . . . . . . . . . . . 127

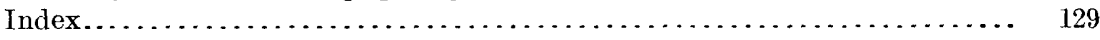




\section{ILLUSTRATIONS.}

Plate I. $A$, Current-meter rating station at Los Angeles, Cal.; $B$, Bridge station and cross section of stream illustrative of 0.2 and 0.8 depth

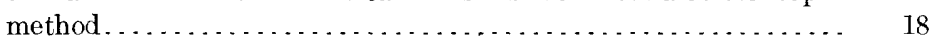

II. Price penta-recording meters ............................. 20

III. $A$, St. Mary canal and dam near Kimball, Alberta; $B$, Dam at Black River Falls, Wis., partly carried away by high water......... 30

IV. Dam and power house at St. Croix Falls, Wis . . . . . . . . . 70

V. Dam on Wisconsin River at Brokaw, Wis.................. 94

Figure 1. Discharge, area, and mean velocity curves of Chippewa River at Chippewa Falls, Wis............................ 23 


\title{
SURFACE WATER SUPPLY OF THE UPPER MISSISSIPPI RIVER AND HUDSON BAY BASINS, 1907-8.
}

\author{
By A. H. Horton, E. F. Chandler, and R. H. Bolster.
}

INTRODUCTION.

AUTHORITY FOR INVESTIGATIONS.

This volume contains results of flow measurements made on certain streams in the United States. The work was performed by the water-resources branch of the United States Geological Survey, either independently or in cooperation with organizations mentioned herein. These investigations are authorized by the organic law of the Geological Survey (Stat. L., vol. 20, p. 394), which provides, among other things, as follows:

Provided that this officer [the Director] shall have the direction of the Geological Survey and the classification of public lands and examination of the geological structure, mineral resources, and products of the national domain.

Inasmuch as water is the most abundant and most valuable mineral in nature, the investigation of water resources is included under the above provision for investigating mineral resources. The work has been supported since the fiscal year ending June 30, 1895, by appropriations in successive sundry civil bills passed by Congress under the following item:

For gaging the streams and determining the water supply of the United States, and for the investigation of underground currents and artesian wells, and for the preparation of reports upon the best methods of utilizing the water resources.

The various appropriations that have been made for this purpose are as follows:

Annual appropriations for the fiscal year ending June 30 -

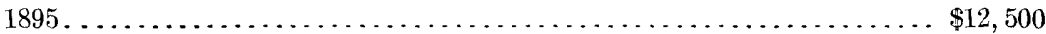

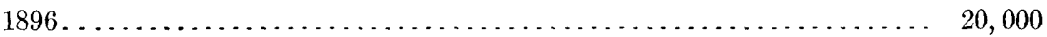

1897 to 1900 , inclusive. . . . . . . . . . . . . . . . . . . 50,000

1901 to 1902 , inclusive. . . . . . . . . . . . . . . . . . . . 100,000

1903 to 1906 , inclusive . . . . . . . . . . . . . . . . . . . . 200, 000

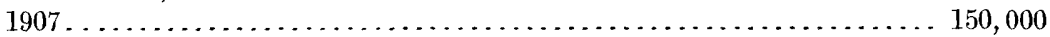

1908 to 1910 , inclusive. . . . . . . . . . . . . . . . . . . 


\section{SCOPE OF INVESTIGATIONS.}

These investigations are not complete nor do they include all the river systems or parts thereof that might purposefully be studied. The scope of the work is limited to that which can be provided with the appropriations available. The field covered and the character of the work are believed to be the best that could be accomplished under the controlling conditions. It would undoubtedly be of more scientific importance and ultimately of more practical value if the money now applied to wide areas were concentrated on a few small basins. Such a course is impossible because general appropriations made by Congress are applicable to all parts of the country. Each part demands its proportionate share of the benefits.

It is essential that records of stream flow shall be maintained during a period of years sufficient to cover all stages, in order that within reasonable limits the entire range of flow from the absolute maximum to the absolute minimum may be determined. The length of such a period manifestly varies for different streams and can not be absolutely determined. Experience has shown that the records should cover from five to ten years, or for some streams twenty years or more, the limit being determined by the relative importance of the stream and the interdependence of the results and other long-time records on adjacent streams.

In the performance of this work the Geological Survey endeavors to approach as nearly as possible the highest degree of precision which a rational expenditure of time and a judicious expenditure of a small amount of money will allow. In all engineering work there is a point of refinement beyond which it is needless and wasteful to proceed, and this principle applies with especial force to stream-flow measurements. It is confidently believed that with some unavoidable exceptions the stream-flow data presented in the publications of the survey are sufficiently accurate for all practical purposes. Many of the records are, however, of insufficient length, owing to the unforeseen reduction of appropriations and consequent abandonment of many stations. All persons are cautioned to exercise the greatest care in the utilization of such incomplete records.

Records of varying lengths have been obtained at about 1,400 different points in the United States, and in addition the surface water supply of small areas in Seward Peninsula and the Yukon-Tanana region, Alaska, has been investigated. During 1907 and 1908 regular gaging stations were maintained by the survey and cooperating organizations at about 740 points in the United States, and in addition numerous miscellaneous measurements were made. Data were also obtained in regard to precipitation, evaporation, storage reservoirs, river profiles, and water power in many sections of the country. 
These data will be made available in the regular surface water-supply papers and in special papers from time to time.

\section{PURPOSES OF THE WORK.}

Among the purposes for which the results contained in this volume are requisite are navigation, irrigation, domestic water supply, water power, swamp and overflow land drainage, and flood prevention. The demands of all these interests are immediate.

Navigation.-The Federal Government has expended more than $\$ 250,000,000$ for the improvement of inland navigation and prospective expenditures will approximate several times this amount. It is obvious that the determination of stream flow is necessary to the intelligent solution of the many problems involved.

Irrigation.-The United States is now expending $\$ 42,000,000$ on federal irrigation systems, and this amount is far exceeded by the private expenditures of this nature in the arid West. The integrity of any irrigation system is based absolutely on the amount of water available. Therefore investigations of stream flow in that portion of the country are of first importance in the redemption of the lands, as well as constituting an insurance of federal and private investments.

Domestic water supply. - The highest use of water is that of domestic supply, and while the federal interest in this aspect of the matter is less direct than in the aspects already named, this use of water, nevertheless, has so broad a significance with respect to the general welfare that the Federal Government is ultimately and intimately concerned.

Water power.- The time is rapidly approaching when the development of the water power of the country will be an economic necessity. Our stock of coal is being rapidly depleted and the cost of steam power is increasing accordingly. Industry will cease its growth if cheap power is not available, and in that event the United States as a nation will cease to progress. Water power is the only avenue now open. When the electric transmission of power was accomplished, the relation of our water powers to national economy changed entirely. Previous to the day of electric transmission the importance of a water power was largely confined to the locality at which it was generated, but it has now become a public utility in which the individual citizen is vitally interested. Inasmuch as the amount of water power that may be made available is dependent on the flow of rivers, the investigation of flow becomes a prerequisite in the judicious management of this source of energy.

Drainage of swamp and overflowed lands.-More than 70,000,000 acres of the richest land in this country are now practically worthless, or of precarious value, by reason of overflow and swamp conditions. When this land is drained it becomes exceedingly produc- 
tive and its value increases many fold. Such reclamation would add to the national assets at least $\$ 700,000,000$. The study of runoff is the first consideration in connection with drainage projects. If, by the drainage of a large area into any particular channel that channel becomes so gorged with water which it had not hitherto been called upon to convey that overflow conditions are created in places where previously the land was not subject to inundation, then drainage results merely in an exchange of land values. This is not the purpose of drainage improvement.

Flood prevention.-The damage from floods in the United States exceeds $\$ 100,000,000$ annually and in the year 1908 the aggregate damage, based on reliable data, approximated $\$ 250,000,000$. Such an annual tax on the property of great regions should be reduced in the orderly progress of government. It goes without saying that any consideration of flood prevention must be based on a thorough knowledge of stream flow, both in the contributing areas which furnish the water and along the great lowland rivers.

\section{PUBLICATIONS.}

The data on stream flow collected by the United States Geological Survey since its inception have appeared in the annual reports, bulletins, and water-supply papers. Owing to natural processes of evolution and to changes in governmental requirements, the character of the work and the territory covered by these different publications has varied greatly. For the purpose of uniformity in the presentation of reports a general plan has been agreed upon by the United States Reclamation Service, the United States Forest Service, the United States Weather Bureau, and the United States Geological Survey, according to which the area of the United States has been divided into twelve parts, whose boundaries coincide with certain natural drainage lines. The areas so described are indicated by the following list of papers on surface water supply for 1907 and 1908. The dividing line between the North Atlantic and South Atlantic drainage areas lies between York and James rivers.

Papers on surface water supply of the United States, 1907-8.

\begin{tabular}{|c|c|c|c|c|c|}
\hline Part. & No. & Title. & Part. & No. & Title. \\
\hline $\begin{array}{l}\text { I } \\
\text { II } \\
\text { III } \\
\text { V }\end{array}$ & $\begin{array}{l}241 \\
242 \\
243 \\
244 \\
245\end{array}$ & $\begin{array}{l}\text { North Atlantic coast. } \\
\text { South Atlantic coast and eastern Gulf } \\
\text { of Mexico. } \\
\text { Ohio River basin. } \\
\text { St. Lawrence River basin. } \\
\text { Cpper Mississippi River and Hudson } \\
\text { Bay basins. }\end{array}$ & 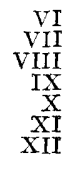 & $\begin{array}{l}246 \\
247 \\
248 \\
249 \\
250 \\
251 \\
252\end{array}$ & $\begin{array}{l}\text { Missouri River basin. } \\
\text { Lower Mississippi River basin. } \\
\text { Western Gulf of Mexico. } \\
\text { Colorado River basin. } \\
\text { Great Basin. } \\
\text { California. } \\
\text { North Pacific coast. }\end{array}$ \\
\hline
\end{tabular}


The following table gives the character of data regarding stream flow at regular stations to be found in the various publications of the United States Geological Survey exclusive of all special papers. Numbers of reports are inclusive and dates also are inclusive so far as the data are available.

\section{Stream-flow data in reports of the United States Geological Survey.}

[Ann. $=$ Annual Report; B.=Bulletin; W. $\mathrm{S} .=$ Water-Supply Paper.]

\begin{tabular}{|c|c|c|}
\hline Report. & Character of data. & Year. \\
\hline 10th Ann., pt. 2 & Deseriptivo information only. & \\
\hline 11th Ann., pt. 2. & Monthly discharge........... & $\begin{array}{l}188 * \text { to Sept., } \\
1890 \text {. }\end{array}$ \\
\hline 12th Ann.,pt. 2 & ....do. & 1884 to June 30 , \\
\hline 13th Ann., pt. 3 . & Mean discharge in second-feet. & 1884 to Dec. 31 , \\
\hline 14th Ann., pt. 2. & Monthly discharge (long-time records, 1871 to 1893 ).. & 1888 to Dee. 31 , \\
\hline B. $131 \ldots \ldots . . . . .2$ & Descriptions, measurements, gage heights, and ratings. & 1893 and 1894. \\
\hline B. $140 \ldots$ & $\begin{array}{l}\text { Descriptions, measurements, gage heights, ratings, and monthly } \\
\text { discharge (also many data covering earlier years). }\end{array}$ & 1895. \\
\hline W. S. 11 . & Gage heights (also gage heights for earlier years) ......... & 1896. \\
\hline 18th Ann., & $\begin{array}{l}\text { Descriptions, measurements, ratings, and monthly discharge } \\
\text { (also similar data for earlier rears). }\end{array}$ & 1895 and 1896. \\
\hline W. S. 15 . & $\begin{array}{l}\text { Descriptions, measurements, and gage heights, eastern United } \\
\text { States, eastern Mississippi River, and Missouri River above } \\
\text { junction with Kansas. }\end{array}$ & 1897. \\
\hline W.S. 16 . & $\begin{array}{l}\text { Descriptions, measurements, and gage heights, western Missis- } \\
\text { sippi River below junction of Missouri and Platte, and west- } \\
\text { ern United States. }\end{array}$ & 1897. \\
\hline 19th Ann., pt. 4. & $\begin{array}{l}\text { Descriptions, measurements, ratings, and monthly discharge } \\
\text { (also some long-time records). }\end{array}$ & 1897. \\
\hline W. S. 27 . & $\begin{array}{l}\text { Measurements, ratings, and gage heights, eastern United States } \\
\text { eastern Mississippi River, and Missouri River. }\end{array}$ & 1898. \\
\hline W. S. 28 & $\begin{array}{l}\text { Measurements, ratings, and gage heights, Arkansas River and } \\
\text { western United States. }\end{array}$ & 1898. \\
\hline 20th Ann., pt. 4 & Monthly discharge (also for many earlier years) ........ & 1898. \\
\hline $\begin{array}{l}\text { W. S. } 35 \text { to } 39 \ldots \\
\text { 21st Ann., pt. } 4 .\end{array}$ & 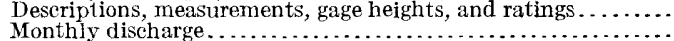 & $\begin{array}{l}1899 . \\
1899\end{array}$ \\
\hline 47 to 52. & Descriptions, measurements, gage heights, and ratings. & 1900. \\
\hline $22 \mathrm{~d} A \mathrm{nl}$ & Monthly discharge........ & 1900. \\
\hline W. & tions, measurements, gage heighis, and rating & 1901. \\
\hline & Monthly discharge... & 1901. \\
\hline W.S. 82 to 85 & Complete data.......... & 1902. \\
\hline W.S. 97 to 10 & ....do. & 1903. \\
\hline W.S. 124 to 1 & .... do. & 1904 . \\
\hline $\begin{array}{l}\text { W. S. } 165 \text { to } 178 \text {. } \\
\text { W.S. } 201 \text { to } 214 .\end{array}$ & xeent descrintion & 1905. \\
\hline W. S. 241 to 252 . & Complete data........... & $\begin{array}{l}1906 . \\
1907-8 .\end{array}$ \\
\hline
\end{tabular}

NotE.-No data regarding stream flow are given in the 15 th and 17 th annual reports.

The records at most of the stations discussed in these reports extend over a series of years. An index of the reports containing records prior to 1904 has been published in Water-Supply Paper 119. The first table which follows gives, by years and drainage basins, the numbers of the papers on surface water supply published from 1899 to 1908. Wherever the data for a drainage basin appear in two papers the number of one is placed in parentheses and the portion of the basin covered by that paper is indicated in the second table. For example, in 1904 the data for Missouri River were published in WaterSupply Papers 130 and 131, and the portion of the records contained in Water-Supply Paper 131, as indicated by the second table, is that relating to Platte and Kansas rivers. 
Numbers of water-supply papers rontaining results of stream measurements, 1899-19c8.

\begin{tabular}{|c|c|c|c|c|c|c|c|c|c|}
\hline & $1899 . a$ & $1900 . b$ & 1901. & 1902. & 1903. & 1904. & 1905. & 1906. & $1907-8$ \\
\hline $\begin{array}{l}\text { Atlantic coast and eastern } \\
\text { Gulf of Mexico: }\end{array}$ & & & & & & & & & \\
\hline $\begin{array}{l}\text { New England rivers..... } \\
\text { Hudson River to Dela- }\end{array}$ & 35 & 47 & 65,75 & 82 & 97 & 124 & 165 & 201 & 241 \\
\hline $\begin{array}{l}\text { ware River, inclusive. } \\
\text { Susquehanna River to }\end{array}$ & 35 & $47,(48)$ & 65,75 & 82 & 97 & 125 & 166 & 202 & 241 \\
\hline $\begin{array}{l}\text { York River, inclusive. } \\
\text { James'River to Yadkin }\end{array}$ & 35 & 48 & 65,75 & 82 & 97 & 126 & 167 & 203 & 241 \\
\hline $\begin{array}{l}\text { River, inclusive. } \\
\text { Santee River to Pearl }\end{array}$ & $(35), 36$ & 48 & 65,75 & $(82), 83$ & $(97), 98$ & 126 & 167 & 203 & 242 \\
\hline River, inclusive...... & 36 & 48 & 65,75 & 83 & 98 & 127 & 168 & 204 & 242 \\
\hline nce River........ & 36 & 49 & 65,75 & $(82), 83$ & 97 & 129 & 170 & 206 & 244 \\
\hline 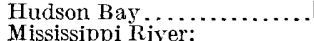 & $\cdots \ldots \ldots$ & .......... & 66,75 & 85 & 100 & 130 & 171 & 207 & 245 \\
\hline Ohio River... & 36 & $48,(49)$ & 65,75 & 83 & 98 & 128 & 169 & 205 & 243 \\
\hline Upper Mississippi River. & 36 & 49 & 65,75 & 83 & $98,(99)$ & $\begin{array}{c}128 \\
(130)\end{array}$ & 171 & 207 & 245 \\
\hline Missouri River. . . . . . . . . & $(36), 37$ & $49,(50)$ & 66,75 & 84 & 99 & $\begin{array}{l}130 \\
(131)\end{array}$ & 172 & 208 & 246 \\
\hline Lower Mississippi River. & 37 & 50 & $\begin{array}{r}(65) \\
66,75\end{array}$ & \}$(83), 84$ & $(98), 99$ & $\begin{array}{c}(128) \\
131\end{array}$ & $\begin{array}{r}(169) \\
173\end{array}$ & $\begin{array}{r}(205) \\
209\end{array}$ & 247 \\
\hline $\begin{array}{l}\text { Western Gulf of Mexico...... } \\
\text { Pacific coast and Great Basin: }\end{array}$ & 37 & 50 & 66,75 & 84 & 99 & 132 & 174 & 210 & 248 \\
\hline Colorado River..... & $(37), 38$ & 50 & 66,75 & 85 & 100 & $\left\{\begin{array}{r}133 \\
(134)\end{array}\right.$ & $(175)$ & $\begin{array}{l}211 \\
(213)\end{array}$ & $\begin{array}{r}249, \\
(251)\end{array}$ \\
\hline Great Basin ......... & $38,(39)$ & 51 & 66,75 & 85 & 100 & $\begin{array}{r}133 \\
(134)\end{array}$ & $\begin{array}{l}176 \\
(177)\end{array}$ & $\begin{array}{r}212 \\
(213)\end{array}$ & $\begin{array}{l}250, \\
(251)\end{array}$ \\
\hline 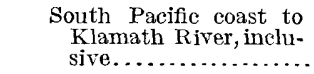 & $(38), 39$ & 51 & 66,75 & 85 & 100 & 134 & 177 & 213 & 251 \\
\hline North Pacific coast.. & 38 & 51 & 66,75 & 85 & 100 & 135 & $\left\{\begin{array}{r}(17 \pi), \\
178\end{array}\right.$ & 214 & 252 \\
\hline
\end{tabular}

a Rating tables and index to Water-Supply Papers 35-39 contained in Water-Supply Paper 39.

Rating tables and index to Water-Supply Papers $47-52$ and data on precipitatjon, wells, and irrigation in California and Utah contained in Water-Supply Paper 56.

Numbers of water-supply papers containing data covering portions of drainage basins.

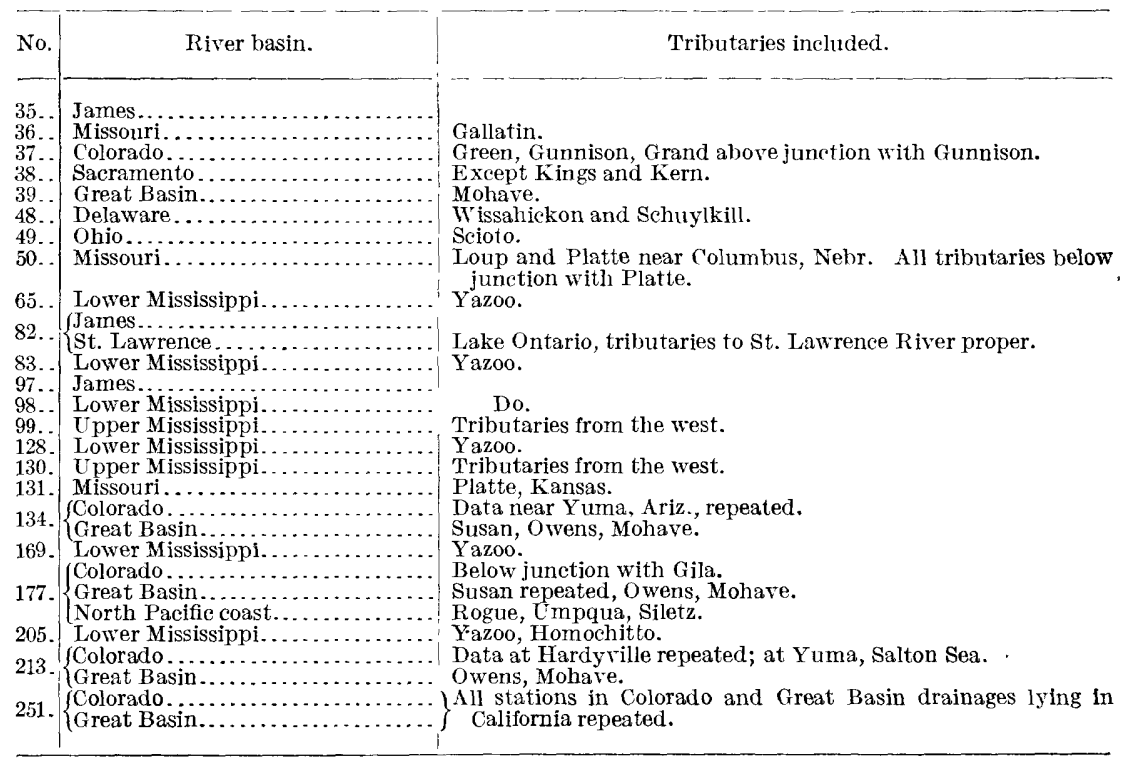

The order of treatment of stations in any basin in these papers is downstream. The main stem of any river is determined on the 
basis of drainage area, local changes in name and lake surface being disregarded. After all stations from the source to the mouth of the main stem of the river have been given, the tributaries are taken up in regular order from source to mouth. The tributaries are treated the same as the main stream, all stations in each tributary basin being given before taking up the next one below.

The exceptions to this rule occur in the records for Mississippi River, which are given in four parts, as indicated above, and in the records for large lakes, where it is often clearer to take up the streams in regular order around the rim of the lake than to cross back and forth over the lake surface.

DEFINITION OF TERMS.

The volume of water flowing in a stream-the "run-off" or "discharge"-is expressed in various terms, each of which has become associated with a certain class of work. These terms may be divided into two groups: (1) Those which represent a rate of flow, as secondfeet, gallons per minute, miner's inches, and run-off in second-feet per square mile, and (2) those which represent the actual quantity of water, as run-off in depth in inches and acre-feet. They may be defined as follows:

"Second-foot" is an abbreviation for cubic foot per second and is the rate of discharge of water flowing in a stream 1 foot wide, 1 foot deep, at a rate of 1 foot per second. It is generally used as a fundamental unit, from which others are computed by the use of the factors given in the following table of equivalents.

"Gallons per minute" is generally used in connection with pumping and city water supply.

The "miner's inch" is the rate of discharge of water that passes through an orifice 1 inch square under a head which varies locally. It is commonly used by miners and irrigators throughout the West and is defined by statute in each State in which it is used.

"Second-feet per square mile" is the average number of cubic feet of water flowing per second from each square mile of area drained, on the assumption that the run-off is distributed uniformly both as regards time and area.

"Run-off in inches" is the depth to which the drainage area would be covered if all the water flowing from it in a given period were conserved and uniformly distributed on the surface. It is used for comparing run-off with rainfall, which is usually expressed in depth in inches.

"Acre-foot" is equivalent to 43,560 cubic feet, and is the quantity required to cover an acre to the depth of 1 foot. It is commonly used in connection with storage for irrigation work. 
CONVENIENT EQUIVALENTS.

\section{The following is a list of convenient equivalents for use in hydraulic computations:}

1 second-foot equals 40 California miner's inches (law of March 23, 1901).

1 second-foot equals 38.4 Colorado miner's inches.

1 second-foot equals 40 Arizona miner's inches.

1 second-foot equals 7.48 United States gallons per second; equals 448.8 gallons per minute; equals 646,272 gallons for one day.

1 second-foot equals 6.23 British imperial gallons per second.

1 second-foot for one year covers 1 square mile 1.131 feet or 13.572 inches deep.

1 second-foot for one year equals $31,536,000$ cubic feet.

1 second-foot equals about 1 acre-inch per hour.

1 second-foot for one day covers 1 square mile 0.03719 inch deep.

1 second-foot for one 28-day month covers 1 square mile 1.041 inches deep.

1 second-foot for one 29-day month covers 1 square mile 1.079 inches deep.

1 second-foot for one 30-day month covers 1 square mile 1.116 inches deep.

1 second-foot for one 31-day month covers 1 square mile 1.153 inches deep.

1 second-foot for one day equals 1.983 acre-feet.

1 second-foot for one 28 -day month equals 55.54 acre-feet.

1 second-foot for one 29-day month equals 57.52 acre-feet.

1 second-foot for one 30-day month equals 59.50 acre-feet.

1 second-foot for one 31-day month equals 61.49 acre-feet.

100 California miner's inches equal 18.7 United States gallons per second.

100 California miner's inches equal 96.0 Colorado miner's inches.

100 California miner's inches for one day equal 4.96 acre-feet.

100 Colorado miner's inches equals 2.60 second-feet.

100 Colorado miner's inches equals 19.5 United States gallons per second.

100 Colorado miner's inches equal 104 California miner's inches.

100 Colorado miner's inches for one day equal 5.17 acre-feet.

100 United States gallons per minute equal 0.223 second-foot.

100 United States galoons per minute for one day equal 0.442 acre-font.

$1,000,000$ United States gallons per day equal 1.55 second-feet.

$1,000,000$ United States gallons equal 3.07 acre-feet.

$1,000,000$ cubic feet equal 22.95 acre-feet.

1 acre-foot equals 325,850 gallons.

1 inch deep on 1 square mile equals $2,323,200$ cubic feet.

1 inch deep on 1 square mile equals 0.0737 second-foot per year.

1 foot equals 0.3048 meter.

1 mile equals 1.60935 kilometers.

1 mile equals 5,280 feet.

1 acre equals 0.4047 hectare.

1 acre equals 43,560 square feet.

1 acre equals 209 feet square, nearly.

1 square mile equals 2.59 square kilometers.

1 cubic foot equals 0.0283 cubic meter.

1 cubic foot equals 7.48 gallons.

1 cubic foot of water weighs 62.5 pounds.

1 cubic meter per minute equals 0.5886 second-foot.

1 horsepower equals 550 foot-pounds per second.

1 horsepower equals 76.0 kilogram-meters per second.

1 horsepower equals 746 watts.

1 horsepower equals 1 second-foot falling 8.80 feet, 
$1 \frac{1}{3}$ horsepower equal about 1 kilowatt.

To calculate water power quickly: Sec. $\frac{\mathrm{ft} . \times \mathrm{fall} \text { in feet }}{11}=$ net horsepower on water wheel realizing 80 per cent of theoretical power.

EXPLANATION OF TABLES.

For each drainage basin there is given a brief description of general conditions covering such features as area, source, tributaries, topography, geology, conditions of forestation, rainfall, ice conditions, irrigation, storage, power possibilities, and other special features of importance or interest.

For each regular current-meter gaging station are given in general, and so far as available, the following data: Description of station, list of discharge measurements, table of daily gage heights, rating table, table of monthly and yearly discharges and run-off. For stations located at weirs or dams the gage-height and rating tables are omitted and a table of daily discharge is substituted. For stations where the flow is computed by shifting-channel methods, a table of daily discharge is given in place of rating tables, which are not used in these methods of computation.

In addition to statements regarding the location and installation of current-meter stations the descriptions give information in regard to any conditions, which may affect the constancy of the relation of gage height to discharge, covering such points as ice, logging, shifting conditions of flow, and backwater; also full information regarding diversions which decrease the total flow at the measuring section. Statements are also made regarding the accuracy and reliability of the data.

The discharge-measurement table gives the results of the discharge measurements made during the year, including the date, name of hydrographer, width and area of cross section, gage height, and discharge in second-feet.

The table of daily gage heights gives the daily fluctuations of the surface of the river as found from the mean of the gage readings taken each day. At most stations the gage is read in the morning and in the evening. The gage height given in the table represents the elevation of the surface of the water above the zero of the gage. All gage heights during ice conditions, backwater from obstructions, etc., are published as recorded, with suitable footnotes. The rating is not applicable for such periods unless the proper correction to the gage heights is known and applied. Attention is called to the fact that the zero of the gage is placed at an arbitrary datum and has no relation to zero flow or the bottom of the river. In general, the zero is located somewhat below the lowest known flow, so that negative readings shall not occur. 
The discharge measurements and gage heights are the base data from which the rating tables and monthly discharge tables are computed.

The rating table gives, either directly or by interpolation, the discharge in second-feet corresponding to every stage of the river recorded during the period for which it is applicable. It is published to enable engineers to determine the daily discharge by its application to the table of gage heights or to check results in the table of monthly discharge.

In the table of monthly discharge the column headed "Maximum" gives the mean flow, as determined from the rating table, for the day when the mean gage height was highest. As the gage height is the mean for the day, it does not indicate correctly the period when the water surface was at crest height and the corresponding discharge consequently larger than given in this column. Likewise, in the column of "Minimum" the quantity given is the mean flow for the day when the mean gage height was lowest. The column headed "Mean" is the average flow in cubic feet for each second during the month. On this the computations for the remaining columns, which are defined on page 13, are based.

\section{FIELD METHODS OF MEASURING STREAM FLOW.}

There are three distinct methods of determining the flow of openchannel streams: (1) By measurements of slope and cross section and the use of Chezy's and Kutter's formulas; (2) by means of a weir or dam; (3) by measurements of the velocity of the current and of the area of the cross section. The method chosen depends on the local plysical conditions, the degree of accuracy desired, the funds available, and the length of time that the record is to be continued.

Slope method.-Much information has been collected relative to the coefficients to be used in the Chezy formula, $v=c \sqrt{R} \bar{s}$. This has been utilized by Kutter, both in developing his formula for $c$ and in determining the values of the coefficient $n$ which appears therein. The results obtained by the slope method are in general only roughly approximate, owing to the difficulty in obtaining accurate data and the uncertainty of the value for $n$ to be used in Kutter's formula. The most common use of this method is in estimating the flood discharge of a stream when the only data available are the cross section, the slope as shown by marks along the bank, and a knowledge of the general conditions. It is seldom used by the United States Geological Survey. For full information regarding this method the reader is referred to the various text-books on hydraulies.

Weir method.--Relatively few stations are maintained at weirs or dams by the United States Geological Survey. Standard types of 
sharp-crested and broad-crested weirs within the limits for which accurate coefficients have been experimentally obtained give very accurate records of discharge if properly maintained. At practically all broad-crested weirs, however, there is a diversion of water either through or around the dam, usually for the purpose of development of water power. The flow is often complicated and the records are subject to errors from such sources as leakage through the dam, backwater at high stages, uncertainty regarding coefficient, crest which is not level, obstructions from logs or ice, use of flashboards, old turbines with imperfect ratings, and many others depending on the type of development and the uses of the diverted water.

In general, records of discharge at dams are usually accurate enough for practical use if no others are available. It has been the general experience of the United States Geological Survey, however, that records at current-meter gaging stations under unobstructed channel conditions are more accurate than those collected at dams, and where the conditions are reasonably favorable are practically as good as those obtained at sharp-crested weirs.

The determination of discharge over the different types of weirs and dams is treated fully in "Weir experiments, coefficients, and formulas" (Water-Supply Paper 200') and in the various textbooks on hydraulics. "Turbine water-wheel tests and power tables" (Water-Supply Paper 180) treats of the discharge through turbines when used as meters. The editions of both of these water-supply papers are practically exhausted. They can, however, be consulted at most of the larger libraries of the country or they can be obtained from the Superintendent of Documents, Washington, D. C., at a cost of 20 cents for No. 180 and 35 cents for No. 200. Remittances must be made by postal money order, express order, or New York draft.

Velocity method.-Streams in general present throughout their courses to a greater or less extent all conditions of permanent, semipermanent, and varying conditions of flow. In accordance with the location of the measuring section with respect to these physical conditions, current-meter gaging stations may in general be divided into four classes-(1) those with permanent conditions of flow; (2) those with beds which change only during extreme high water; (3) those with beds which change frequently but which do not cause a variation of more than about 5 per cent of the discharge curves from year to year; and (4) those with constantly shifting beds. In determining the daily flow different office methods are necessary for each class. The field data on which the determinations are based and the methods of collecting them are, however, in general the same. 
Great care is taken in the selection and equipment of gaging stations for determining discharge by velocity measurements, in order that the data may have the required degree of accuracy. They are located, as far as possible, at such points that the relation between gage height and discharge will always remain constant for any given stage. The experience of engineers of the Geological Survey has been that permanency of conditions of flow is the prime requisite of any current-meter gaging station when maintained for several years, unless funds are available to cover all changes in conditions of flow. A straight, smooth section without cross currents, backwater, boils, etc., at any stage is highly desirable, but on most streams is not attainable except at the cost of a cable equipment. Rough, permanent sections, if measurements are properly made by experienced engineers, taking measuring points at a distance apart of 2 to 5 per cent, or less, of the total width, will within reasonable limits yield better results for a given outlay of money than semipermanent or shifting sections with smooth, uniform current. So far as possible stations are located where the banks are high and not subject to overflow at high stages, and out of the influence of tributary streams, dams, or other artificial obstructions which might affect the relation between gage height and discharge.

A gaging station consists essentially of a gage for determining the daily fluctuations of stage of the river and some structure or apparatus from which discharge measurements are made, usually a bridge or cable.

The two factors required to determine the discharge of a stream past a section perpendicular to the mean direction of the current are the area of the cross section and the mean velocity of flow normal to that section.

In making a measurement with a current meter a number of points, called measuring points, are measured off above and in the plane of the measuring section at which observations of depth and velocity are taken. (See Pl. I, B.) These points are spaced equally for those parts of the section where the flow is uniform and smooth and are spaced unequally for other parts according to the discretion and judgment of the engineer. In general the points should not be spaced farther apart than 5 per cent of the distance between piers, nor farther apart than the approximate mean depth of the section at the time of measurement.

The measuring points divide the total cross section into elementary strips, at each end of which observations of depth and velocity are made. The discharge of any elementary strip is the product of the average of the depths at the two ends times the width of the strip times the average of the mean velocities at the two ends of the strip. The sum of the discharges of the elementary strips is the total 


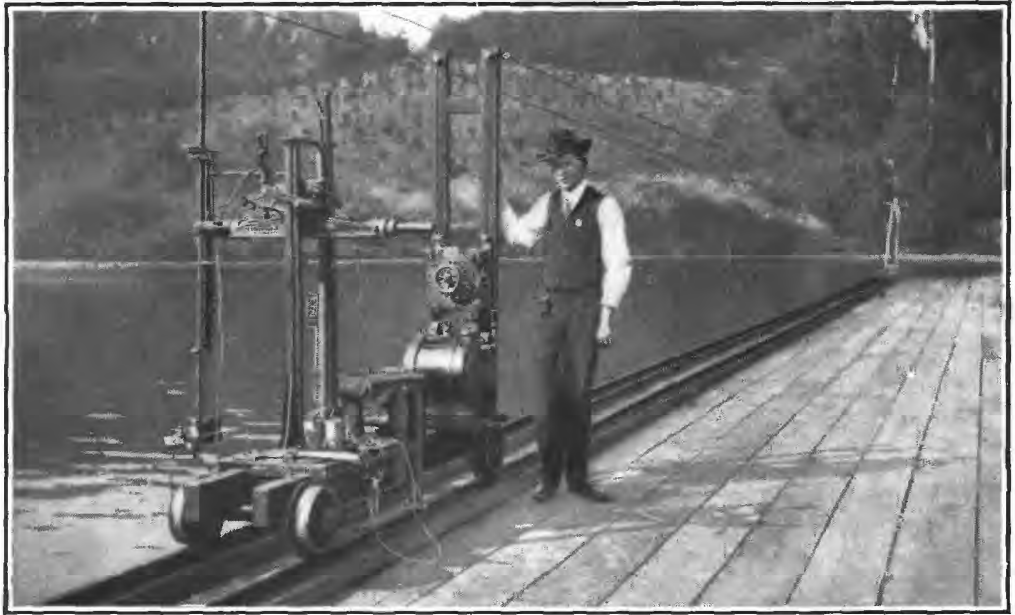

a. CURRENT-MEter Rating Station at los ANGELES, Cal.

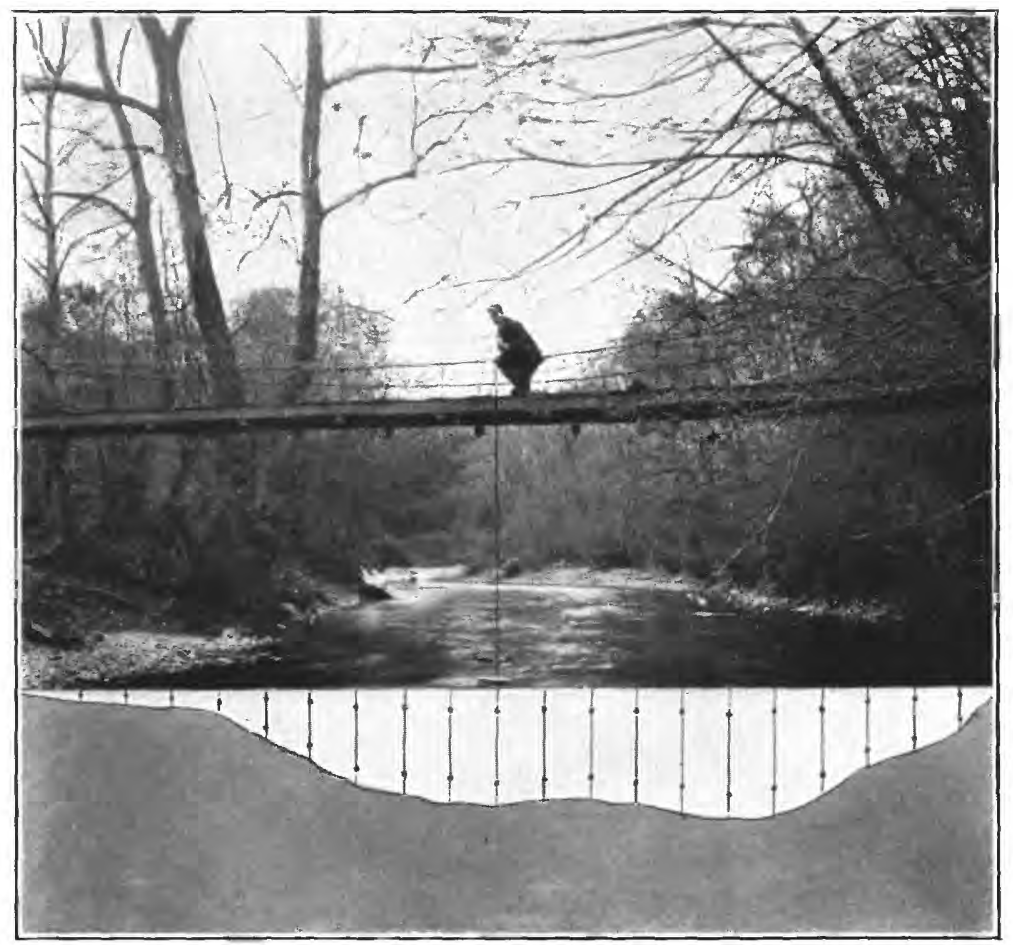

B. BRIDGE STATION AND CROSS SECTION OF STREAM.

lllustrating 0.2 and 0.8 depth method. 
discharge of the stream. (For a discussion of methods of computing the discharge of a stream see Engineering News, June 25, 1908.)

Depths for the determination of the area are usually obtained by sounding with the current meter and cable. In rough sections or swift current an ordinary weight and cable are used, particular care being taken that all observations shall be in the plane of the cross section.

Two methods of determining the velocity of flow of a stream are in general use-the float method and the current-meter method.

The float method with its various modifications of surface, subsurface, and tube or rod floats is now considered obsolete in the ordinary practice of the United States Geological Survey. The use of this method is limited to special conditions where it is impracticable to use the current meter, such as in places where large quantities of ice or débris which may damage the meter are flowing with the current, and for miscellaneous measurements or other work where a high degree of accuracy is not necessary. Tube floats are very satisfactory for use in canals with regular bottoms and even flow of current. Measurements by the float method are made as follows: The velocity of flow of the stream is obtained by observing the time which it takes floats set free at different points across the stream to pass between two range lines about 200 feet apart. The area used is the mean value obtained from several cross sections measured between the two range lines. The chief disadvantages of this method are difficulty in obtaining the correct value of mean area for the course used and uncertainty regarding the proper coefficient to apply to the observed velocity. For further information regarding this method the reader is referred to Water-Supply Paper 95 and to the various text-books covering the general subject of stream flow.

The Price current meter is now used almost to the exclusion of other types of meters by the United States Geological Survey in the determination of the velocity of flow of water in open channels, a use for which it is adapted under practically all conditions. Plate II shows in the center the new type of penta-recording current meter equipped for measurements at bridge and cable stations. On the sides the same type of meter is shown equipped for wading measurements to record by the acoustic method on the left and by the electric method on the right. Briefly, the meter consists of six cups attached to a vertical shaft which revolves on a conical hardened steel point when immersed in moving water. The number of revolutions is indicated electrically. The rating, or relation between the velocity of the moving water and the revolutions of the wheel, is determined for each meter by drawing it through still water for a given distance at different speeds and noting the number of revolutions for each run. (See Pl. I, A.) From these data a rating table is prepared 
which gives the velocity per second of moving water for any number of revolutions in a given time interval. The ratio of revolutions per second to velocity of flow in feet per second is very nearly a constant for all speeds and is approximately 0.45 .

Three classes of methods of measuring velocity with current meters are in general use-multiple point, single point, and integration.

The two principal multiple-point methods in general use are the vertical velocity curve and 0.2 and 0.8 depth.

In the vertical velocity curve method a series of velocity determinations are made in each vertical at regular intervals, usually about 10 to 20 per cent of the depth apart. By plotting these velocities as abscissas and their depths as ordinates and drawing a smooth curve among the resulting points the vertical velocity curve is developed. This curve shows graphically the magnitude and changes in velocity from the surface to the bottom of the stream. The mean velocity in the vertical is then obtained by dividing the area bounded by this velocity curve and its axis by the depth. This method of obtaining the mean velocity in the vertical is probably the best known, but on account of the length of time required to make a complete measurement its use is largely limited to the determination of coefficients for purposes of comparison and to measurements under ice.

In the second multiple-point method the meter is held successively at 0.2 and 0.8 depth and the mean of the velocities at these two points is taken as the mean velocity for that vertical. (See Pl. I, B.) On the assumption that the vertical velocity curve is a common parabola with horizontal axis, the mean of the velocities at 0.22 and 0.79 depth will give (closely) the mean velocity in the vertical. Actual observations under a wide range of conditions show that this multiple-point method gives the mean velocity very closely for open-water conditions and that in a completed measurement it seldom varies as much as 1 per cent from the value given by the vertical velocity curve method. Moreover, the indications are that it holds nearly as well for ice-covered rivers. It is very extensively used in the regular practice of the United States Geological Survey.

The single-point method consists in holding the meter either at the depth of the thread of mean velocity or at an arbitrary depth for which the coefficient for reducing to mean velocity has been determined or must be assumed.

Extensive experiments by means of vertical velocity curves show that the thread of mean velocity generally occurs between 0.5 and 0.7 total depth. In general practice the thread of mean velocity is considered to be at 0.6 depth, and at this point the meter is held in most of the measurements made by the single-point method. A large number of vertical velocity curve measurements, taken on many streams and under varying conditions, show that the average 


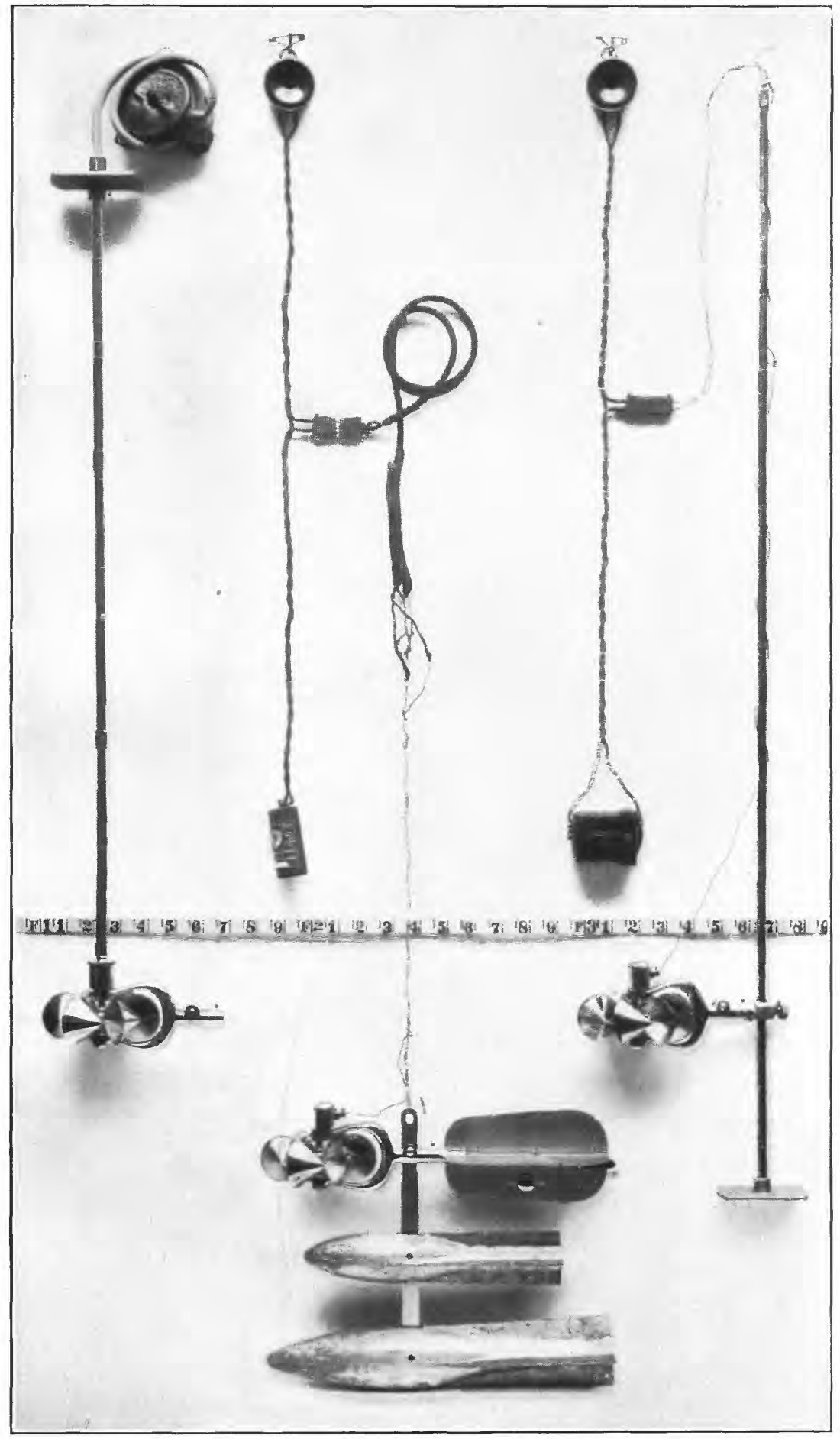

PRICE PENTA-RECORDING CURRENT METERS. 
coefficient for reducing the velocity obtained at 0.6 depth to mean velocity is practically unity. The variation of the coefficient from unity in individual cases is, however, greater that in the 0.2 and 0.8 method and the general results are not as satisfactory.

In the other principal single-point method the meter is held near the surface, usually 1 foot below, or low enough to be out of the effect of the wind or other disturbing influences. This is known as the subsurface method. The coefficient for reducing the velocity taken at the subsurface to the mean has been found to be in general from about 0.85 to 0.95 , depending on the stage, velocity, and channel conditions. The higher the stage the larger the coefficient. This method is especially adapted for flood measurements, or when the velocity is so great that the meter can not be kept in the correct position for the other methods.

The vertical integration method consists in moving the meter at a slow, uniform speed from the surface to the bottom and back again to the surface and noting the number of revolutions and the time taken in the operation. This method has the advantage that the velocity at each point of the vertical is measured twice. It is useful as a check on the point methods. In using the Price meter great care should be taken that the vertical movement of the meter is not rapid enough to vitiate the accuracy of the resulting velocity.

The determination of the flow of an ice-covered stream is difficult, owing to diversity and instability of conditions during the winter period and also to lack of definite information in regard to the laws of flow of water under ice. The method now employed is to make frequent discharge measurements during the frozen periods by the 0.2 and 0.8 and the vertical velocity curve methods, and to keep an accurate record of the conditions, such as the gage height to the surface of the water as it rises in a hole cut in the ice, and the thickness and character of the ice. From these data an approximate estimate of the daily flow can be made by constructing a rating curve (really a series of curves) similar to that used for open channels, but considering, in addition to gage heights and discharge, the varying thickness of ice. For information in regard to flow under ice cover, see Water-Supply Paper 187.

OFFICE METHODS OF COMPUTING AND STUDYING DISCIARGE AND RUN-OFF.

At the end of each year the field or base data for current-meter gaging stations, consisting of daily gage heights, discharge measurements, and full notes, are assembled. The measurements are plotted on cross-section paper and rating curves are drawn wherever feasible. The rating tables prepared from these curves are then applied to the tables of daily gage heights to obtain the daily discharges, and 
from these applications the tables of monthly discharge and run-off are computed.

Rating curves are drawn and studied with special reference to the class of channel conditions which they represent. (See p. 17.) The discharge measurements for all classes of stations when plotted with gage heights in feet as ordinates and discharges in second-feet as abscissas define rating curves which are more or less generally parabolic in form. In many cases curves of area in square feet and mean velocity in feet per second are also constructed to the same scale of ordinates as the discharge curve. These are used mainly to extend the discharge curves beyond the limits of the plotted discharge measurements, and for checking purposes to avoid errors in the form of the discharge curve and to determine and eliminate erroneous measurements.

For every published rating table the following assumptions are made for the period of application of the table: $(a)$ That the discharge is a function of and increases gradually with the stage; (b) that the discharge is the same whenever the stream is at a given stage, and hence such changes in conditions of flow as may have occurred during the period of application are either compensating or negligible, except that the rating as stated in the footnote of each table is not applicable for known conditions of ice, log jams, or other similar obstructions; (c) that the increased and decreased discharge due to change of slope on rising and falling stages is either negligible or compensating.

As already stated the gaging stations may be divided into several classes, as indicated in the following paragraphs:

The stations of class 1 represent the most favorable conditions for an accurate rating and are also the most economical to maintain. The bed of the stream is usually composed of rock and is not subject to the deposit of sediment and loose material. This class includes also many stations located in a pool below which is a permanent rocky riffle that controls the flow like a weir. Provided the control is sufficiently high and close to the gage to prevent cut and fill at the gaging point from materially affecting the slope of the water surface, the gage height will for all practical purposes be a true index of the discharge. Discharge measurements made at such stations usually plot within 2 or 3 per cent of the mean-discharge curve and the rating developed from that curve represents a very high degree of accuracy. For illustrative example of a station of this type see figure 1 and Water-Supply Paper 241.

Class 2 is confined mainly to stations on rough mountainous streams with steep slopes. The beds of such streams are as a rule comparatively permanent during low and medium stages and when the flow is sufficiently well defined by an adequate number of discharge 
INTRODUCTION.

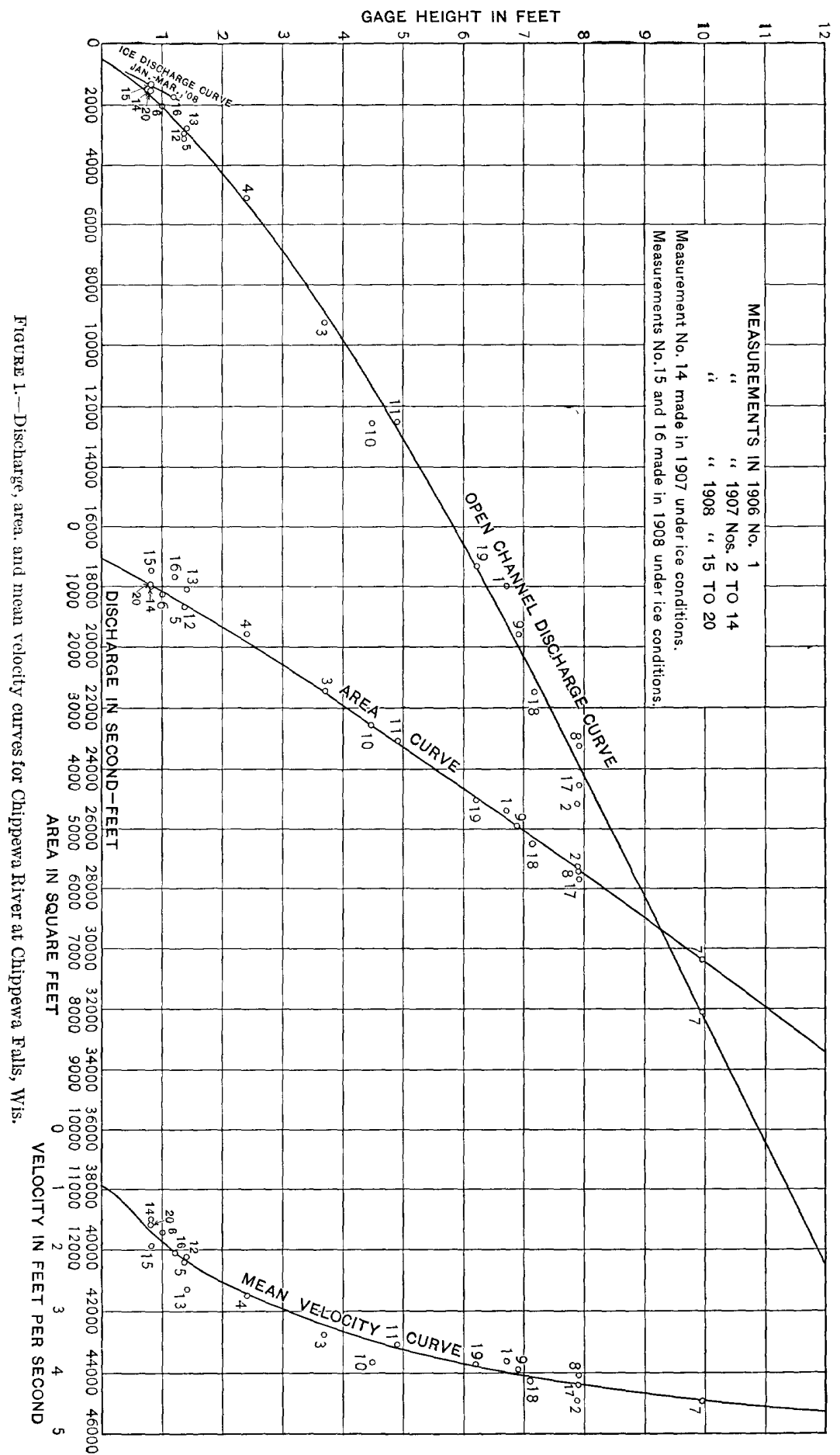


measurements before and after each flood the stations of this class give nearly as good results as those of class 1 . As it is scldom possible to make measurements covering the time of change at flood stage, the assumption is of ten made that the curves before and after the flood converged to a common point at the highest gage height recorded during the flood. IIence the only uncertain period occurs during the few days of highest gage heights covering the period of actual change in conditions of flow. For illustrative examples of stations of this type see Water-Supply Paper 246.

Class 3 includes most of the current-meter gaging stations maintained by the United States Geological Survey. (See fig. 1.) If sufficient measurements could be made at stations of this class, results would be obtained nearly equaling those of class 1 , but owing to the limited funds at the disposal of the Survey this is manifestly impossible, nor is it necessary for the uses to which discharge data are applied. The critical points are as a rule at relatively high or low stages. The percentage error, however, is greater at low stages. No absolute rule can be laid down for stations of this class. Each rating curve must be constructed mainly on the basis of the measurements of the current year, the engineer being guided largely by the past history of the station and the following general law: If all measurements ever made at a station of this class are plotted on cross-section paper, they will define a mean curve which may be called a standard curve. It has been found in practice that if after a change caused by high stage, a relatively constant condition of flow occurs at medium and low stages, all measurements made after the change will plot on a smooth curve which is practically parallel to the standard curve with respect to their ordinates, or gage heights. This law of the parallelism of ratings is the fundamental basis of all ratings and estimates at stations with semi-permanent and shifting channels. It is not absolutely correct but, with few exceptions, answers all the practical requirements of estimates made at low and medium stages after a change at a high stage. This law appears to hold equally true whether the change occurs at the measuring section or at some controlling point below. The change is of course fundamentally due to change in the channel caused by cut, or fill, or both, at and near the measuring section. For all except small streams the changes in section usually occur at the bottom. The following simple but typical examples illustrate this law:

(a) If 0.5 foot of planking were to be nailed on the bottom of a well-rated wooden flume of rectangular section there would result, other conditions of flow being equal, new curves of discharge, area, and velocity, each plotting 0.5 foot above the original curves when referred to the original gage. In other words, this condition would be analogous to a uniform fill or cut in a river channel which either 
reduces or increases all three values of discharge, area, and velocity for any gage height. In practice, however, such ideal conditions rarely exist.

(b) In the case of a cut or fill at the measuring section there is a marked tendency toward decrease or increase, respectively, of the velocity. In other words, the velocity has a compensating effect and if the compensation is exact at all stages the discharge at a given stage will be the same under both the new and the old conditions.

(c) In the case of uniform change along the crest of a weir or rocky controlling point, the area curve will remain the same as before the change, and it can be shown that here again the change in velocity curve is such that it will produce a new discharge curve essentially parallel to the original discharge curve with respect to their ordinates.

Of course in actual practice such simple changes of section do not occur. The changes are complicated and lack uniformity, a cut at one place being largely offset by a fill at another and vice versa. If these changes are very radical and involve large percentages of the total area-as, for example, on small streams-there may result a wide departure from the law of parallelism of ratings. In complicated changes of section the corresponding changes in velocity which tend to produce a new parallel discharge curve may interfere with each other materially, causing eddies, boils, backwater, and radical changes in slope. In such extreme conditions, however, the measuring section would more properly fall under class 4 and would require very frequent measurements of discharge. Special stress is laid on the fact that in the lack of other data to the contrary the utilization of this law will yield the most probable results.

Slight changes at low or medium stages of an oscillating character are usually averaged by a mean curve drawn among them parallel to the standard curve, and if the individual measurements do not vary more than 5 per cent from the rating curve the results are considered good for stations of this class. For illustrative example of a station of this type see Water-Supply Paper 242.

Class 4 comprises stations that have soft, muddy, or sandy beds. Good results can be obtained from such sections only by frequent discharge measurements, the frequency varying from a measurement every two or three weeks to a measurement every day, according to the rate of diurnal change in conditions of flow. These measurements are plotted and a mean or standard curve drawn among them. It is assumed that there is a different rating curve for every day of the rear and that this rating is parallel to the standard curve with respect to their ordinates. On the day of a measurement the rating curve for that day passes through that measurement. For days between successive measurements it is 
assumed that the rate of change is uniform, and hence the ratings for the intervening days are equally spaced between the ratings passing through the two measurements. This method must be modified or abandoned altogether under special conditions. Personal judgment and a knowledge of the conditions involved can alone dictate the course to pursue in such cases. For illustrative examples of a station of this type, showing the Bolster method of determining the daily discharge graphically, see Water-Supply Papers 247 and 249.

The computations have, as a rule, been carried to three significant figures. Computation machines, Crelle's tables, and the 20-inch slide rule have been generally used. All computations are carefully checked.

After the computations have been completed they are entered in tables and carefully studied and intereompared to eliminate or account for all gross errors so far as possible. Missing periods are filled in, so far as is feasible, by means of comparison with adjacent streams. The attempt is made to complete years or periods of discharge, thus eliminating fragmentary and disjointed records. Full notes accompanying such estimates follow the monthly discharge tables.

For most of the northern stations estimates have been made of the monthly discharge during frozen periods. These are based on measurements under ice conditions wherever available, daily records of temperature and precipitation obtained from the United States Weather Bureau climate and crop reports, observers' notes of conditions, and a careful and thorough intercomparison of results with adjacent streams. Although every care possible is used in making these estimates they are often very rough, the data for some of them being so poor that the estimates are liable to as much as 25 to 50 per cent error. It is believed, however, that estimates of this character are better than none at all, and serve the purpose of indicating in a relative way the proportionate amount of flow during the frozen period. These estimates are, as a rule, included in the annual discharge. The large error of the individual months has a relatively small effect on the annual total, and it is for many purposes desirable to have the yearly discharge computed, even though some error is involved in doing so.

\section{ACCURACY AND RELIABILITY OF FIELD DATA AND COMPARATIVE} RESUITS.

Practically all discharge measurements made under fair conditions are well within 5 per cent of the true discharge at the time of observation. Inasmuch as the errors of meter measurements are largely compensating, the mean rating curve, when well defined, is much more accurate than the individual measurements. Numerous 
tests and experiments have been made to test the accuracy of currentmeter work. These show that it compares very favorably with the results from standard weirs, and, owing to simplicity of methods, usually gives results that are much more reliable than those from stations at dams, where uncertainty regarding the coefficient and complicated conditions of flow prevail.

The work is, of course, dependent on the reliability of the observers. With relatively few exceptions, the observers perform their work honestly. Care is taken, however, to watch them closely and to inquire into any discrepancies. It is, of course, obvious that one gage reading a day does not always give the mean height for that day. As an almost invariable rule, however, errors from this source are compensating and virtually negligible in a period of one month, although a single day's reading may, when taken by itself, be considerably in error.

In order to give engineers and others information regarding the probable accuracy of the computed results, footnotes are added to the rating tables and an accuracy column is inserted in the monthly discharge table. In the rating tables "well defined" indicates in general that the rating is probably accurate within 5 per cent;"fairly well defined," within 10 per cent; "poorly defined" or "approximate" within 15 to 25 per cent. These notes are very general and are based on the plotting of the individual measurements with reference to the mean rating curve.

The accuracy column in the monthly discharge table does not apply to the maximum or minimum nor to any individual day, but to the monthly mean. It is based on the accuracy of the rating, the probable reliability of the observer, and knowledge of local conditions. In this column, A indicates that the mean monthly flow is probably accurate within 5 per cent; B, within 10 per cent; C, within 15 per cent; D, within 25 per cent. Special conditions are covered by footnotes.

USE OF THE DATA.

In general the policy is followed of making available for the public the base data which are collected in the field each year by the Survey engineers. This is done to comply with the law, but also for the express purpose of giving to any engineer the opportunity of examining the computed results and of changing and adjusting them as may seem best to him. Although it is believed that the rating tables and computed monthly discharges are as good as the base data up to and including the current year will warrant, it should always be borne in mind that the additional data collected at each station from year to year nearly always throw new light on data already collected and published, and hence allow more or less improvement in the computed results of earlier years. It is therefore expected that the engineer 
who makes serious use of the data given in these papers will verify all ratings and make such adjustments in earlier years as may seem necessary. The work of compiling, studying, revising, and republishing data for different drainage basins for five or ten year periods or more is carried on by the United States Geological Survey so far as the funds for such work are available.

The values in the table of monthly discharge are so arranged as to give only a general idea of the conditions of flow at the station, and it is not expected that they will be used for other than preliminary estimates. This is particularly true of the maximum and minimum figures, which in the very nature of the method of collecting these data are liable to large errors. The maximum value should be increased considerably for many stations in considering designs for spillways, and the minimum value should be considered for a group of, say, seven days and not for one day.

The rating table, provided the engineer accepts it, is published primarily to allow him to apply it directly to the daily gage heights and rearrange the daily discharges in order of magnitude or by some other method.

\section{COOPERATION AND ICKNOWLEDGMENTS.}

Assistance has been rendered or records furnished by the following to whom special acknowledgment is due: United States Weather Bureau, United States Reclamation Service, Wisconsin Valley Improvement Company, Great Northern Development Company, and Mr. Frank Dearborn. The State of Illinois cooperates in the stream gaging work being done in that State, the appropriation being under the control of the Internal Improvement Commission, Mr. Isham Randolph, chairman.

\section{DIVISION OF WORK.}

The field data for the upper Mississippi River drainage were collected under the direction of L. S. Smith, A. H. Horton, and J. C. Hoyt, assisted by G. A. Gray, R. J. Taylor, and Wm. M. O'Neill.

The field data for the Hudson Bay drainages were collected under the direction of J. E. Stewart, district engineer, assisted by E. F. Chandler, A. F. Huch, and J. B. Pierson.

The ratings, special estimates and studies of the completed data were made by A. H. Horton, R. H. Bolster, Robert Follansbee, and E. F. Chandler.

The computations and preparation of the completed data for publication were made under the direction of R. H. Bolster, assistant engineer, assisted by Robert Follansbee, G. C. Stevens, H. D. Padgett, R. C. Rice, J. G. Mathers, and M. I. Walters. The entire report was edited by Mrs. B. D. Wood. 


\section{HUDSON BAY DRAINAGE.}

\section{GENERAL FEATURES.}

All the waters that reach Hudson Bay from the United States pass through Lake Winnipeg and thence into the bay through Nelson River. The two principal tributaries of Lake Winnipeg, and thus, indirectly, of Nelson River, are the Saskatchewan and Red River. The Saskatchewan drains the major portions of the provinces of Alberta and Saskatchewan and the northwestern part of Assiniboia, in the Dominion of Canada, and, through St. Mary River, a small area in northwestern Montana in the United States. Red River drains a large basin in the United States, covering portions of Minnesota and North and South Dakota. Both rivers are large and important.

\section{ST. MARY RIVER DRAINAGE BASIN.}

DESCRIPTION.

St. Mary River heads in northern Montana, near the Canadian boundary line, on the eastern slope of the main range of the Rocky Mountains, in a region of perpetual snow, and in the midst of numerous glaciers. It starts from the great Blackfoot Glacier, probably the largest in the Rocky Mountains within the United States, and receives affluents from at least a dozen lesser glaciers. These small streams unite within a short distance from their source and flow into a lake hemmed in by high mountains known as Upper St. Mary Lake Below this lake, and separated from it by a narrow strip of land, is Lower St. Mary Lake. The aggregate length of these two lakes is about 22 miles. The river flows out of the lower lake, the elevation of which is 4,460 feet above sea level, and within 2 miles is joined by Swiftcurrent Creek, which is fed by waters of Grinnell Glacier and four small glaciers. From the confluence of these streams to the international boundary, a distance of 12 miles, the St. Mary flows in a northerly direction, receiving Kennedy Creek a few miles before crossing the boundary. Entering the province of Alberta it empties into Belly River, its waters eventually finding their way through the Saskatchewan into Hudson Bay.

That portion of the drainage area below the region of glaciers has a heavy forest covering, consisting of spruce and fir timber on the higher slopes, and a dense growth of willows and aspen on the lower portions.

The mean annual rainfall is about 60 inches, of which the greater part occurs in the form of snow during the winter months. The altitude of the drainage basin within the United States ranges from 4,000 feet to 10,000 feet.

The only diversion from the St. Mary in the United States is that which is being made by the U. S. Reclamation Service in connection 
with the Milk River project. It is proposed to reservoir Lower St. Mary Lake and divert 850 second-feet of water into the Milk River drainage basin. Both Upper and Lower St. Mary lakes can be made into storage reservoirs. A view of St. Mary canal and dam near Kimball, Alberta, is shown in Plate III, $A$. Water-power possibilities are not important in the basin as the many small streams which form the river are frozen over during the winter months.

The following gaging stations have been maintained in this drainage basin:

St. Mary River at Main, Mont., 1901-1902.

St. Mary River near Babb (formerly Dam Site), Mont., 1902-1908.

St. Mary River near Cardston, Alberta, 1902-1908.

Swiftcurrent Creek near Babb (formerly Wetzel), Mont., 1902-1908.

Kennedy Creek near Babb (formerly Wetzel), Mont., 1903-1906.

\section{ST. MARY RIVER NEAR BABB, MONT.}

This station, which was established April 9, 1902, for the purpose of securing run-off data in connection with irrigation projects on the Blackfoot Indian Reservation and in the Milk River Valley, is located about 4,500 feet below Lower St. Mary Lake, and about 2,500 feet above the mouth of Swiftcurrent Creek, the nearest tributary. The run-off at this point is that from Upper and Lower St. Mary lakes. The drainage area is 177 square miles. There is no diversion above the station. The United States Reclamation Service has appropriated 850 second-feet of water from this stream which will be diverted near the station. A reservoir will also be formed at Lower St. Mary Lake.

The datum of the gage has remained constant since the station has been established. The records at this station are excellent except during the winter months, when ice conditions affect the results.

Discharge measurements of St. Mary River near Babb, Mont., in 1907 and 1908.

\begin{tabular}{|c|c|c|c|c|c|}
\hline Date. & Hydrographer. & Width. & $\begin{array}{l}\text { Area of } \\
\text { section. }\end{array}$ & $\begin{array}{c}\text { Gage } \\
\text { height. }\end{array}$ & $\begin{array}{c}\text { Dis- } \\
\text { charge. }\end{array}$ \\
\hline $\begin{array}{l}1907 . \\
\text { March } 20\end{array}$ & & Feet. & $S q . f t$ & Feet. & Sec.-ft. \\
\hline $\begin{array}{l}\text { March } 20 . . . \\
\text { March } 30 a . .\end{array}$ & $\begin{array}{c}\text { W. S. Hanna } \ldots \ldots \ldots \ldots \ldots \\
\ldots \ldots \ldots \ldots \ldots \ldots\end{array}$ & $\ldots$ & $\begin{array}{l}72 \\
75\end{array}$ & $\begin{array}{l}1.75 \\
1.65\end{array}$ & $\begin{array}{l}167 \\
162\end{array}$ \\
\hline May 14... & J. E. Stewart. & 95 & 184 & 3.05 & 691 \\
\hline June $5 .$. & J. B. Pierson.. & 106 & 369 & 4.88 & 2,230 \\
\hline July $1 .$. & $\ldots \ldots \ldots \ldots \ldots \ldots$ & 106 & 432 & 5. 60 & 3,010 \\
\hline August 7 & $\ldots \ldots \ldots \ldots \ldots \ldots$ & $9 \tilde{z}$ & 245 & 3.58 & 1,120 \\
\hline September $6 . .$. & Follansbee and Pierson. . & 90 & 192 & 3.11 & 761 \\
\hline $\begin{array}{r}1908 . \\
\text { April } 17 . .\end{array}$ & A. F. Huch. & 76 & $8 \overline{5}$ & 1.85 & 171 \\
\hline June 19 . & .... do ..... & 110 & 419 & 4.84 & 3,140 \\
\hline July 25. & Stewart and Huch.. & 95 & 230 & 3.30 & 1,020 \\
\hline August 21 & ....do............. & 80 & 136 & 2.17 & 525 \\
\hline August & $\ldots \ldots \ldots \ldots \ldots \ldots$, & 165 & 197 & 2.17 & 501 \\
\hline October & A. F. Huch... & 65 & 130 & 1.49 & 199 \\
\hline
\end{tabular}

$a$ Snowdrift in stream at left bank.

$b$ Wading measurement, above the gage.

$c$ Wading measurement. one-fourth mile below the gage. 


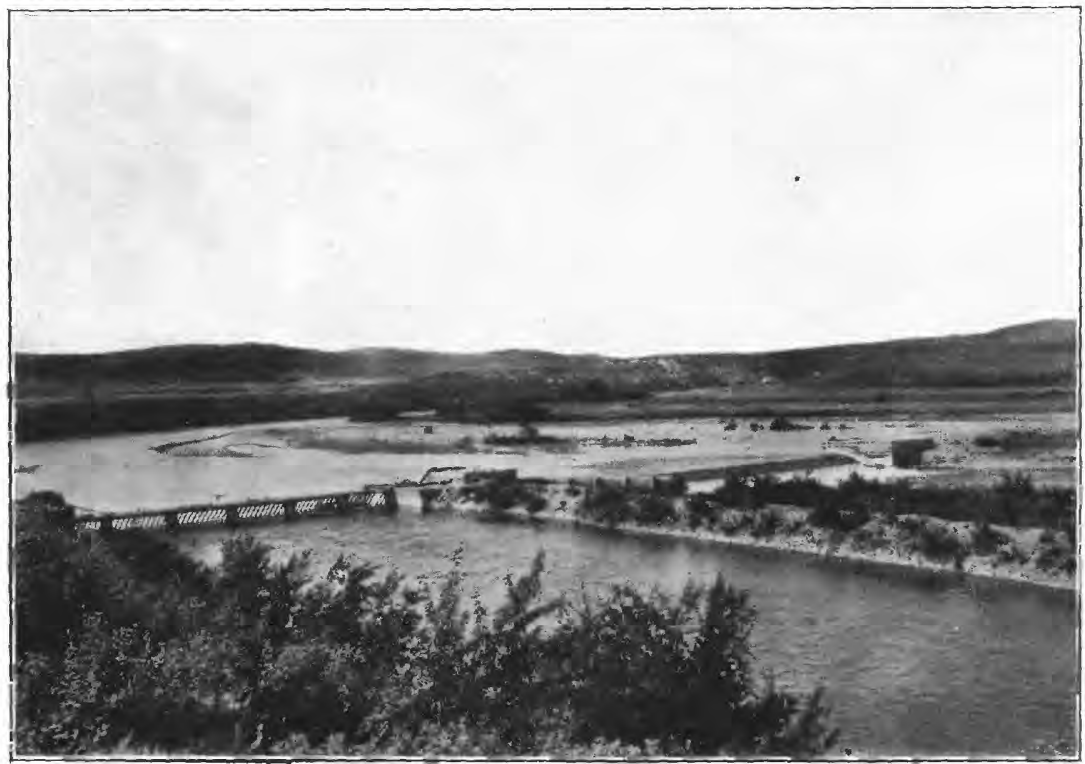

A. ST, MARY CANAL AND DAM NEAR KIMBALL, ALBERTA.

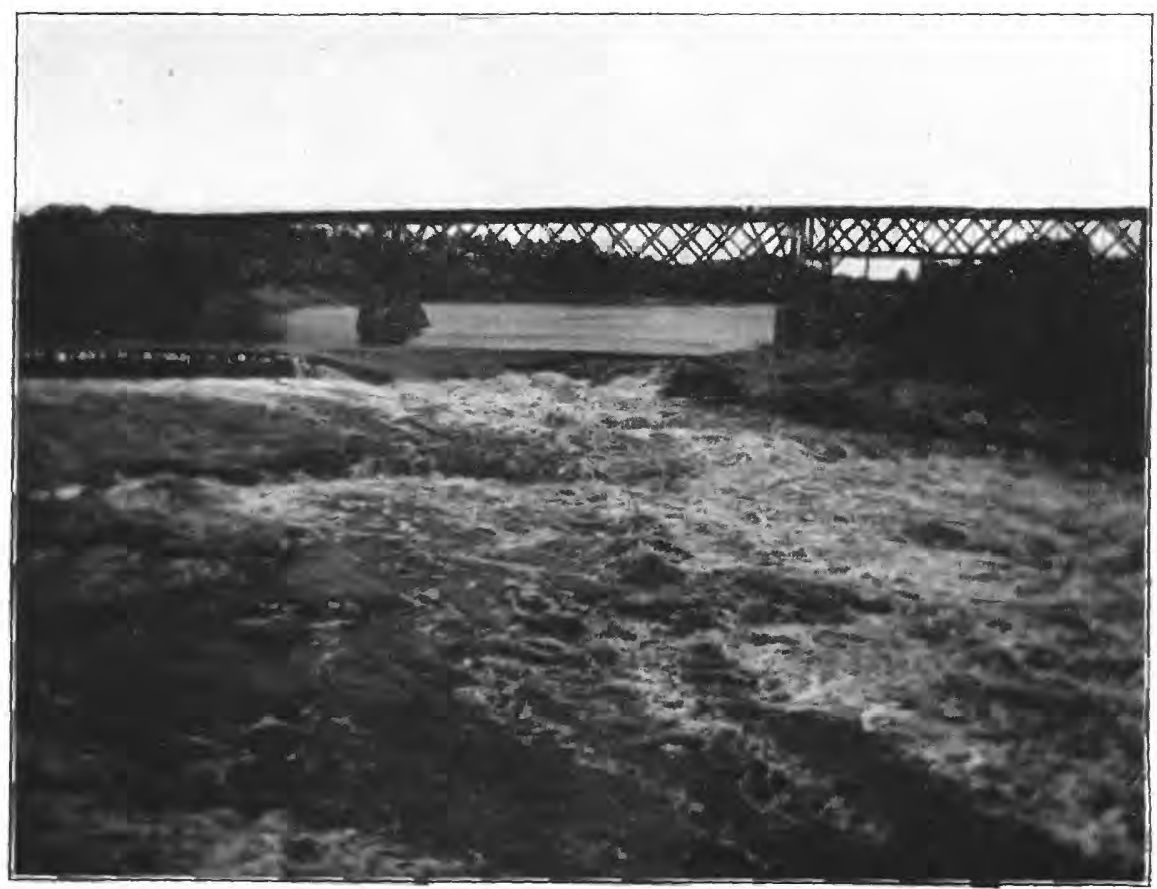

B. DAM AT BLACK RIVER FALLS, WIS., PARTLY CARRIED AWAY BY HIGH WATER. 
Daily gage height, in feet, of St. Mary River near Babb, Mont., for 1907 and 1908.

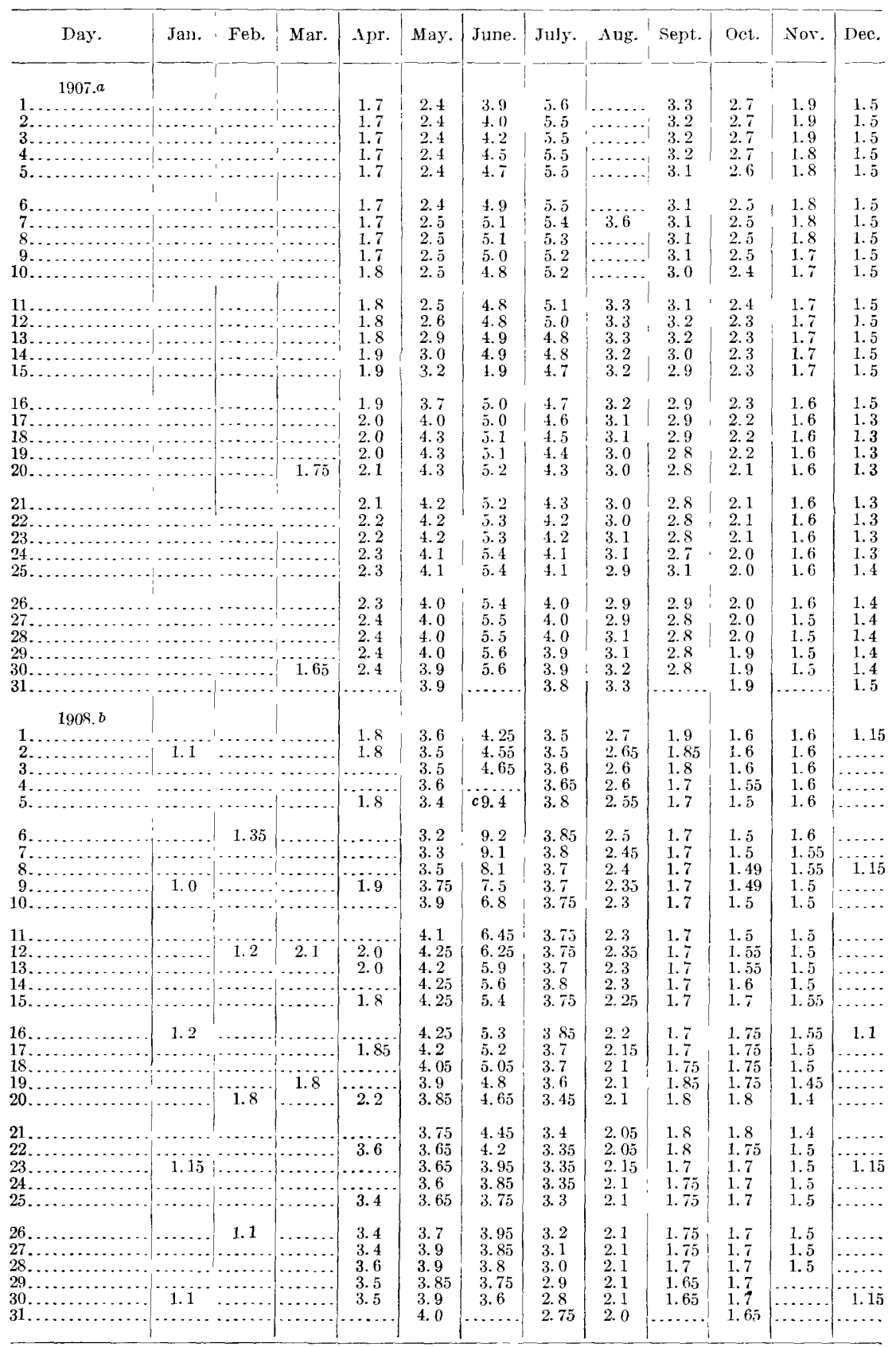

$a$ Tce conditions prevailed January 1 to March 31, 1907.

$b$ Ice conditions prevailed from January 1 to about March 31 and November 29 to December $31,1908$. During the former period readings were to under surface of ice and during the lat ter period they were to water surface in a hole cut in the ice.

$c$ Gage height estimated. 
Rating tables for St. Mary River near Babb, Mont.

JANUARY 1, 1907, TO JUNE 3, 1908.

\begin{tabular}{|c|c|c|c|c|c|c|c|}
\hline $\begin{array}{l}\text { Gage } \\
\text { height. }\end{array}$ & $\begin{array}{l}\text { J)is- } \\
\text { charge. }\end{array}$ & $\begin{array}{c}\text { Gage } \\
\text { height. }\end{array}$ & $\begin{array}{l}\text { Dis- } \\
\text { charge. }\end{array}$ & $\begin{array}{c}\text { Gage } \\
\text { height. }\end{array}$ & $\begin{array}{c}\text { Dis- } \\
\text { charge. }\end{array}$ & $\begin{array}{c}\text { Gage } \\
\text { height. }\end{array}$ & $\begin{array}{l}\text { Jis- } \\
\text { cllarge. }\end{array}$ \\
\hline Feet. & Sec. $f t$. & Fect. & Sec.-ft. & Feet. & Sec.-ft. & Fect. & Scc.-jt. \\
\hline 1. 10 & 19 & 2. 10 & 270 & 3.10 & 765 & 4.20 & 1,625 \\
\hline 1. 20 & 31 & 2.20 & 3077 & 3.20 & 835 & 4.40 & 1,800 \\
\hline 1.30 & 47 & 2.30 & 346 & 3.39 & 905 & 4. 60 & 1,980 \\
\hline 1.40 & 67 & 2. 40 & 388 & 3.40 & 980 & 4.80 & 2,160 \\
\hline 1.50 & 90 & 2.50 & 433 & 3.50 & 1,055 & 5.00 & 2,350 \\
\hline 1.60 & 115 & 2. 60 & 481 & 3.60 & 1,130 & 5.20 & 2,550 \\
\hline 1.70 & 142 & 2. 70 & 532 & 3.70 & 1,210 & 5. 40 & 2,760 \\
\hline 1.80 & 171 & 2.80 & .585 & 3.80 & 1,290 & 5. 60 & 2,980 \\
\hline 1.90 & 202 & 2. 90 & 640 & 3. 90 & 1,370 & 5.80 & 3,220 \\
\hline 2.00 & 235 & 3.00 & 700 & 4.00 & 1,455 & 6.00 & 3,460 \\
\hline
\end{tabular}

Noтk.--The above table is not applicable for ice or obstructed-channel conditions. It is based on six discharge measurements made during 1907 , one made during 1908 , and the form of previous rating curves. It is well defined above gage height 1.7 feet.

JUNE 5 TO DECEMBER $31,1908$.

\begin{tabular}{|c|c|c|c|c|c|c|c|}
\hline $\begin{array}{l}\text { Gage } \\
\text { height. }\end{array}$ & $\begin{array}{l}\text { Dis- } \\
\text { charge. }\end{array}$ & $\begin{array}{l}\text { Gage } \\
\text { height. }\end{array}$ & $\begin{array}{l}\text { Dis- } \\
\text { charge. }\end{array}$ & $\begin{array}{c}\text { Gage } \\
\text { height. }\end{array}$ & $\begin{array}{l}\text { Dis- } \\
\text { charge. }\end{array}$ & $\begin{array}{c}\text { Gage } \\
\text { height. }\end{array}$ & $\begin{array}{l}\text { Dis- } \\
\text { charge. }\end{array}$ \\
\hline Feet. & Sec.-ft. & Fect. & Sec.-ft. & Feet. & Sec.-ft. & Feet. & Sec.-ft. \\
\hline 1.00 & $\begin{array}{r}70 \\
70\end{array}$ & 2.10 & 466 & 3.20 & 1.140 & 4.60 & 2,400 \\
\hline 1.10 & 94 & 2.20 & 516 & 3.30 & 1,220 & 4.80 & 2,610 \\
\hline 1.20 & 120 & 2.30 & 568 & 3.40 & 1,300 & 5.00 & 2,830 \\
\hline 1.30 & 148 & 2.40 & 623 & 3.50 & 1,380 & 5.20 & 3,050 \\
\hline 1. 40 & 178 & 2.50 & 680 & 3.60 & 1,460 & 5. 40 & 3,270 \\
\hline 1.50 & 211 & 2. 60 & $7 \pm 0$ & 3.70 & 1,540 & 5.60 & 3,490 \\
\hline 1. 60 & 247 & 2.70 & 800 & 3.80 & 1,630 & 5.80 & 3,710 \\
\hline 1.70 & 286 & 2.80 & 865 & 3.90 & 1,720 & 6.00 & 3,950 \\
\hline 1.80 & 328 & 2.90 & 930 & 4.00 & 1,810 & 7.00 & 5,150 \\
\hline 1.90 & 372 & 3.00 & 1,000 & 4. 20 & 2,000 & 8.00 & 6,300 \\
\hline 2.00 & 418 & 3.10 & 1,070 & 4. 40 & 2,200 & 9.00 & 7,500 \\
\hline
\end{tabular}

Note.-The above table is not applicable for ice or obstructed-channel conditions. It is based on three discharge measurements made during 1908 and the form of previous rating curves. It is well defined between gage heights 1.5 and 2.5 feet, and is believed to be accurately located above gage height 2.5 feet.

Monthly discharge of St. Mary River near Babb, Mont., for 190' and 1908.

[Urainage area, 177 square miles.]

\begin{tabular}{|c|c|c|c|c|c|c|c|}
\hline \multirow[b]{2}{*}{ Month. } & \multicolumn{4}{|c|}{ Discharge in second-feet. } & \multicolumn{2}{|c|}{ Run-off. } & \multirow[b]{2}{*}{$\begin{array}{l}\text { Accu- } \\
\text { racy. }\end{array}$} \\
\hline & Maximum. & Minimum. & Mean. & $\begin{array}{l}\text { Per } \\
\text { square } \\
\text { mile. }\end{array}$ & $\begin{array}{l}\text { Depth in } \\
\text { inches } \\
\text { on drain- } \\
\text { age area. }\end{array}$ & $\begin{array}{l}\text { Total in } \\
\text { acre-feet. }\end{array}$ & \\
\hline $190 \pi$. & & & & & & & \\
\hline Jannlary $a \ldots \ldots$. & & & 80 & 0.452 & 0.52 & 4,920 & D. \\
\hline February i. ...... & - & & 110 & .622 & .65 & 6,110 & D. \\
\hline March $a . .$. & $\therefore$ 政 & & 80 & .452 & .52 & 4,920 & D. \\
\hline April ... & 388 & 112 & 234 & 1.32 & 1.47 & 13,900 & B. \\
\hline May. & 1,710 & 388 & 1,010 & 5.71 & 6.58 & 62,100 & A. \\
\hline June...... . & 2,980 & 1,370 & 2,370 & 13.4 & 14.92 & 141,000 & A. \\
\hline$\ldots \ldots \ldots \ldots \ldots$ & 2,980 & 1,290 & 2,090 & 11.8 & 13.61 & 129,000 & A. \\
\hline August..... & 1,290 & 640 & 893 & 5.05 & 5.82 & 54,900 & A. \\
\hline$\ldots \ldots \ldots \ldots$. & 905 & 532 & 694 & 3.94 & 4.40 & 41,300 & A. \\
\hline October.... & 532 & 202 & 343 & 1.94 & 2.24 & 21,100 & B. \\
\hline November... & 202 & 90 & 136 & .769 & .86 & 8,090 & C. \\
\hline December... & 90 & 47 & 74.5 & .421 & 49 & 4,580 & D. \\
\hline The year.. & 2,980 & & 676 & 3.82 & 52.08 & 492,000 & \\
\hline
\end{tabular}

a Ice conditions and discharge estimated. 
Monthly discharge of St. Mary River near Babb, Mont., for 1907 and 1908-Continued.

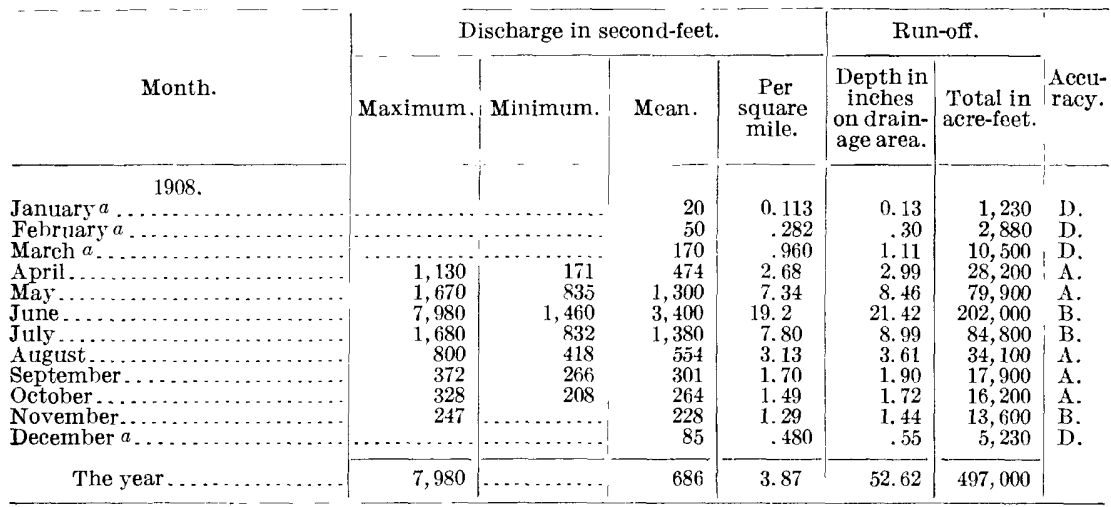

a Ice conditions and discharge estimated.

ST. MARY RIVER NEAR CARDSTON, ALBERTA.

This station was established September 4, 1902, near Shaws ranch, one-fourth mile north of the boundary line between the United States and Canada and 17 miles south of Cardston, Alberta, for the purpose of obtaining data for use in connection with irrigation projects in the Milk River valley.

The station is 6 miles below the mouth of Kennedy Creek, the last tributary entering from the United States. With the exception of Boundary Creek, a small stream entering a short distance above the station, the drainage area lies within the United States. The total drainage area is 452 square miles.

The only diversion above the station is that which is being made at Babb by the United States Reclamation Service in connection with the Milk River project. About 850 second-feet of water will be diverted into the Milk River drainage basin.

During high water in June, 1908, the gage was destroyed and the channel changed. A new gage was put in July 17, 1908, about onefourth mile below the old station. There is no relation between the two gages. Results at this station are good except during the winter months, when they are affected by ice.

Discharge measurements of St. Mary River near Cardston, Alberta, in $190 \%$ and 1908.

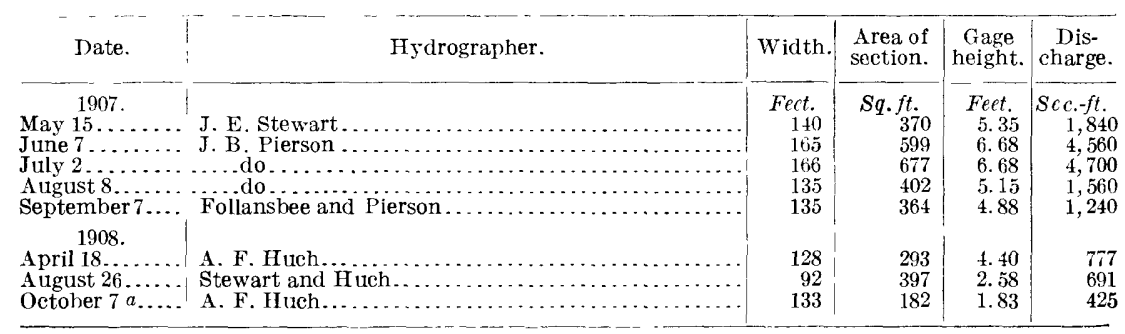

$a$ Wading measurement, 400 feet below cable. 
Daily gage height, in feet, of St. Mary River near Cardston, Alberta, for 1907 and 1908.

\begin{tabular}{|c|c|c|c|c|c|c|c|c|c|c|c|c|c|}
\hline Day. & & 1. & , & & Apr. & May. & June. & July. & Aug. & Sept. & Oct. & Nov. & Dec. \\
\hline $\begin{array}{l}1 . . \\
2 . . \\
3 \ldots \\
4 \ldots \\
5 . .\end{array}$ & & & & & $\begin{array}{l}3.2 \\
3.35 \\
3.5 \\
3.45 \\
3.45\end{array}$ & $\begin{array}{l}4.05 \\
4.05 \\
4.1 \\
4.1 \\
4.1\end{array}$ & $\begin{array}{l}6.5 \\
6.6 \\
6.5 \\
6.4\end{array}$ & $\begin{array}{l}6.75 \\
6.7 \\
6.65 \\
6.6 \\
6.6\end{array}$ & $\begin{array}{l}5.45 \\
5.4 \\
5.3 \\
5.3 \\
5.25\end{array}$ & $\begin{array}{l}4.95 \\
4.95 \\
4.85 \\
4.85 \\
4.85\end{array}$ & \begin{tabular}{l}
4.65 \\
4.65 \\
\hdashline 4.45 \\
4.4
\end{tabular} & $\begin{array}{l}3.6 \\
3.55 \\
3.55 \\
3.55 \\
3.5\end{array}$ & $\begin{array}{l}\text { 3. } 25 \\
\text { 3. } 25 \\
\text { 3. } 25 \\
\text { 3. } 2\end{array}$ \\
\hline $\begin{array}{r}6 . \\
7 . \\
8 . \\
9 . \\
10 .\end{array}$ & & & & & $\begin{array}{l}3.35 \\
3.3 \\
3.35 \\
3.45 \\
3.6\end{array}$ & $\begin{array}{l}4.15 \\
4.45 \\
4.35 \\
4.6 \\
4.85\end{array}$ & \begin{tabular}{l|}
6.7 \\
6.75 \\
6.7 \\
6.5
\end{tabular} & $\begin{array}{l}6.4 \\
6.3 \\
6.2 \\
6.1 \\
6.1\end{array}$ & $\begin{array}{l}5.2 \\
5.2 \\
5.15 \\
5.1\end{array}$ & $\begin{array}{l}4.85 \\
4.85 \\
4.8 \\
4.7 \\
4.75\end{array}$ & $\begin{array}{l}4.4 \\
4.35 \\
4.35 \\
4.3 \\
4.3\end{array}$ & $\begin{array}{l}3.5 \\
3.45 \\
3.4 \\
3.35 \\
3.3\end{array}$ & $\begin{array}{l}\text { 3. } 15 \\
\text { 3. } 15 \\
\text { 3. } 1 \\
\text { 3. } 1 \\
\text { 3. } 0\end{array}$ \\
\hline ... & & & & & $\begin{array}{l}3.75 \\
3.85 \\
\because 3.95 \\
3.95\end{array}$ & $\begin{array}{l}5.05 \\
5.25 \\
5.3 \\
5.35 \\
5.45\end{array}$ & $\begin{array}{l}6.4 \\
6.35 \\
6.3 \\
6.25 \\
6.2\end{array}$ & $\begin{array}{l}6.1 \\
6.0 \\
6.1\end{array}$ & $\begin{array}{l}5.05 \\
5.05 \\
5.0 \\
4.95 \\
4.9\end{array}$ & $\begin{array}{l}4.8 \\
4.8 \\
4.8\end{array}$ & $\begin{array}{l}4.25 \\
4.2\end{array}$ & $\begin{array}{l}3.3 \\
3.25 \\
3.25 \\
3.2\end{array}$ & $\begin{array}{l}2.9 \\
2.9 \\
2.8\end{array}$ \\
\hline i. & & & & & $\begin{array}{l}4.0 \\
4.05 \\
4.05 \\
4.05 \\
4.05\end{array}$ & $\begin{array}{l}6.0 \\
6.2 \\
6.15 \\
6.1\end{array}$ & \begin{tabular}{l|}
6.15 \\
6.1 \\
6.1 \\
6.15 \\
6.2
\end{tabular} & $\begin{array}{l}5.95 \\
5.9 \\
5.9 \\
5.85 \\
5.8\end{array}$ & $\begin{array}{l}4.9 \\
4.8 \\
4.75 \\
4.6 \\
4.55\end{array}$ & $\begin{array}{l}4.85 \\
4.9 \\
4.95 \\
4.9 \\
4.9\end{array}$ & $\begin{array}{l}3.95 \\
3.95 \\
3.9\end{array}$ & $\begin{array}{l}3.15 \\
3.15 \\
3.1 \\
3.1 \\
3.1\end{array}$ & 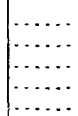 \\
\hline \%. & & & & 4.0 & $\begin{array}{l}4.1 \\
4.1 \\
4.15 \\
4.15 \\
4.15\end{array}$ & $\begin{array}{l}6.0 \\
6.0 \\
5.85 \\
5.7 \\
5.6\end{array}$ & $\begin{array}{l}6.95 \\
7.05 \\
6.75 \\
6.65\end{array}$ & \begin{tabular}{l|}
5.8 \\
5.85 \\
5.8 \\
5.75
\end{tabular} & $\begin{array}{l}4.55 \\
4.5 \\
4.4 \\
7.6\end{array}$ & $\begin{array}{l}4.85 \\
4.85 \\
4.85 \\
4.85 \\
4.85\end{array}$ & $\begin{array}{l}\text { 3. } 85 \\
\text { 3.85 } \\
\text { 3.8 }\end{array}$ & $\begin{array}{l}\text { 3. } 05 \\
3.0 \\
3.0 \\
3.0 \\
3.0\end{array}$ & \\
\hline . & & & & 3.2 & $\begin{array}{l}4.2 \\
\ldots .1 \\
4.1 \\
4.1 \\
4.05 \\
\cdots \cdots\end{array}$ & $\begin{array}{l}5.6 \\
5.5 \\
5.5 \\
5.5 \\
5.7 \\
6.0\end{array}$ & \begin{tabular}{l|}
6.6 \\
6.75 \\
6.8 \\
6.9 \\
6.8
\end{tabular} & $\begin{array}{l}5.7 \\
5.6 \\
5.65 \\
5.5 \\
5.5 \\
5.45\end{array}$ & $\begin{array}{l}4.55 \\
4.6 \\
4.9 \\
4.9 \\
5.0 \\
4.95\end{array}$ & $\begin{array}{l}4.8 \\
4.8 \\
4.8 \\
4.8 \\
4.7 \\
\ldots \ldots\end{array}$ & $\begin{array}{l}3.8 \\
\dddot{3.7} \\
3.7 \\
3.65 \\
3.6\end{array}$ & $\begin{array}{l}3.1 \\
3.1 \\
3.15 \\
3.15 \\
3.2\end{array}$ & \\
\hline Day & A & May. & June. & & Day & Apr. & May. & Jun & $\mathrm{D}$ & & Apr. & May. & June. \\
\hline 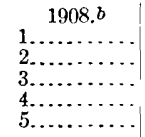 & $\begin{array}{l}3.55 \\
3.30\end{array}$ & $\begin{array}{l}4.95 \\
5.00 \\
5.00 \\
5.05 \\
5.10\end{array}$ & $\begin{array}{c}6.95 \\
6.80 \\
6.60 \\
7.35 \\
\cdots . . .\end{array}$ & $\begin{array}{l}11 . \\
12 . \\
13 . \\
14 . \\
15 .\end{array}$ & 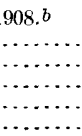 & $\begin{array}{l}3.80 \\
3.90\end{array}$ & $\begin{array}{l}5.85 \\
6.00 \\
6.05 \\
6.05 \\
6.10\end{array}$ & & $\begin{array}{l}1 \\
21 . \\
22 . \\
23 . \\
24 . \\
25 .\end{array}$ & $\cdots$ & 5.35 & $\begin{array}{l}5.60 \\
5.55 \\
5.50 \\
5.50 \\
5.50\end{array}$ & \\
\hline $\begin{array}{l}6 \ldots \ldots \ldots \ldots \\
7 \ldots \ldots \ldots \ldots \\
8 \ldots \ldots \ldots \ldots \\
9 \ldots \ldots \ldots \ldots \\
10 \ldots \ldots \ldots \ldots\end{array}$ & $\begin{array}{l}3.30 \\
3.30 \\
3.25 \\
3.20 \\
3.25\end{array}$ & $\begin{array}{l}5.40 \\
5.70 \\
5.80 \\
5.85\end{array}$ & & $\begin{array}{l}16 . \\
17 . \\
18 . \\
19 . \\
20 .\end{array}$ & $\cdots$ & $\begin{array}{l}3.95 \\
4.10 \\
4.40 \\
4.90\end{array}$ & $\begin{array}{l}6.10 \\
6.00 \\
5.70 \\
5.70\end{array}$ & & $\begin{array}{l}29 . \\
30 . \\
31 .\end{array}$ & . & \begin{tabular}{l|}
5.30 \\
5.25 \\
5.20 \\
5.10 \\
5.00
\end{tabular} & $\begin{array}{l}5.90 \\
6.30 \\
6.10 \\
5.80 \\
5.80 \\
6.20\end{array}$ & \\
\hline
\end{tabular}

$a$ Ice conditions prevailed from January 1 to about March 31, 1907. December 15 to 31, 1907, open channel in center of river but no water at gage.

$b$ Ice conditions prevailed from January 1 to April 1 and from December 11 to 30, 1908. Gage and cable washed out by high water June 5 and replaced by new equipment July 27, 1908. The new gage was placed at a different section and to a new datum. The crest stage of the flood was estimated 12.75 feet.

Rating table for St. Mary River near Cardston, Alberta, for January 1, 1907, to June 4, 1908.

\begin{tabular}{|c|c|c|c|c|c|c|c|}
\hline $\begin{array}{l}\text { Gage } \\
\text { height. }\end{array}$ & $\begin{array}{c}\text { Dis- } \\
\text { charge. }\end{array}$ & $\begin{array}{c}\text { Gage } \\
\text { height. }\end{array}$ & $\begin{array}{c}\text { Dis- } \\
\text { charge. }\end{array}$ & $\begin{array}{c}\text { Gage } \\
\text { height. }\end{array}$ & $\begin{array}{c}\text { Dis- } \\
\text { charge. }\end{array}$ & $\begin{array}{c}\text { Gage } \\
\text { height. }\end{array}$ & $\begin{array}{c}\text { Dis- } \\
\text { charge. }\end{array}$ \\
\hline Feet. & Sec.-ft. & Feet. & Sec.-ft. & Feet. & sec.-ft. & Feet. & Sec.fft. \\
\hline 3.00 & 174 & 4. 00 & 560 & 5. 00 & 1,390 & 6. 00 & 3,040 \\
\hline 3.10 & 198 & 4.10 & 620 & 5. 10 & 1,510 & 6.20 & 3,490 \\
\hline 3.20 & 225 & 4. 20 & 685 & 5. 20 & 1,640 & 6. 40 & 3,960 \\
\hline 3.30 & 255 & 4. 30 & 755 & 5. 30 & 1,780 & 6. 60 & 4,450 \\
\hline 3.40 & 288 & 4. 40 & 830 & 5.40 & 1,930 & 6.80 & 4,960 \\
\hline 3.50 & 325 & 4.50 & 910 & b. 50 & 2,090 & 7.00 & 5,490 \\
\hline 3. 60 & 365 & 4.60 & 995 & 5. 60 & 2,260 & 7.20 & 6,040 \\
\hline 3. 70 & 410 & 4.70 & 1,085 & 5. 70 & 2,440 & & \\
\hline 380 & 455 & 4.80 & 1.180 & 5. 80 & 2,630 & & \\
\hline 3.90 & 505 & 4.90 & 1,280 & 5. 90 & 2,830 & & \\
\hline
\end{tabular}

Note.-The above table is not applicable for ice or obstructed-channel conditions. It is based on 33 discharge measurements made during 1902 to 1908 , and is well defined. 
Monthly discharge of St. Mary River near Cardston, Alberta, for 1907 and 1908.

[Drainage area, 452 square miles.]

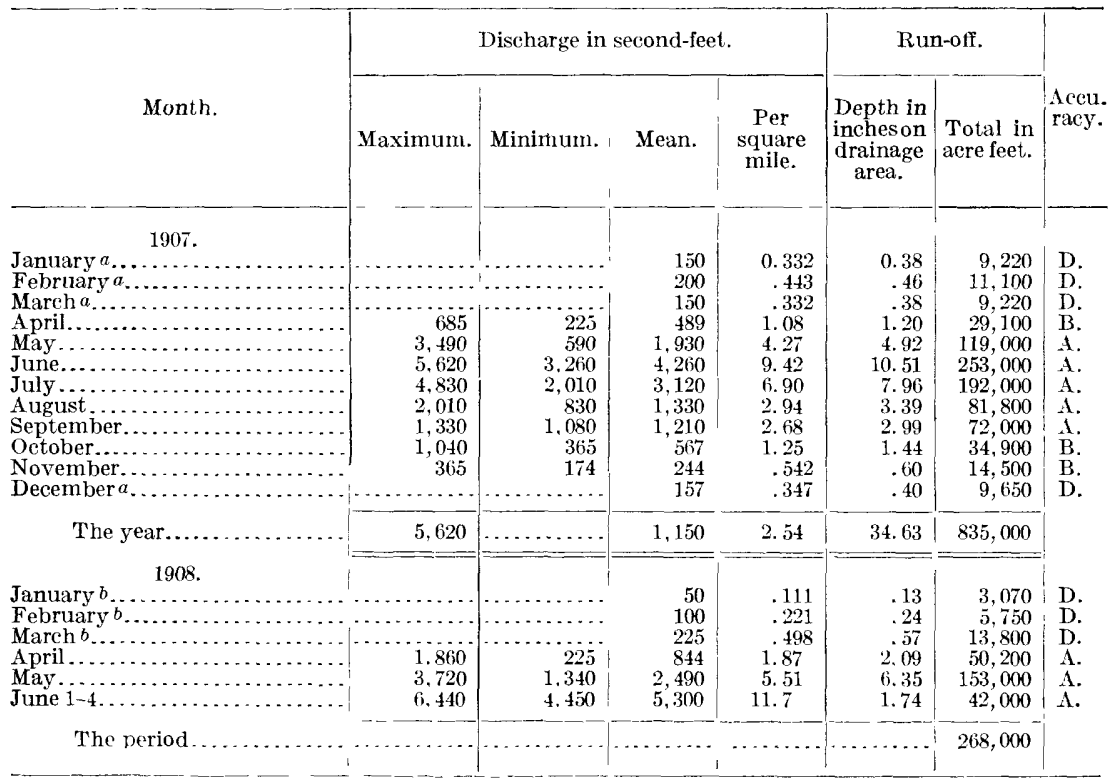

$a$ Ice conditions and discharge estimated January to Mareh and December 15-31, 1907. $b$ lce conditions and discharge estimated.

Note.-Discharge June 5 to December 31,1908 withheld pending the taking of further discharge nleasurements to properly define the rating curve for the new section.

\section{SWIFTCURRENT CREEK NEAR BABB, MONT.}

This station is located about 1 mile from the mouth of the stream, at a point where it leaves the foothills. It was established April 8, 1902, to obtain data for use in connection with irrigation projects on the Blackfoot Indian Reservation and in the Milk River valley. The drainage area above this station is 101 square miles.

There is no diversion or storage above this station. It is possible to construct storage reservoirs on this stream, and because of the great fall which the stream has, considerable power can be developed. Although the current is swift, the flow during the winter months is to some extent affected by ice.

The gage first established was washed away by high water in June, 1902, and the station was reestablished July 30, 1902, at a point 1,800 feet above the first gage. It was again moved September 27 , 1902 , to a point about 900 feet farther up stream, and set at a different datum. It remained at this location until it was destroyed by the high water June 5, 1908. July 26, 1908, the gage was reestablished at a new datum, about 100 feet above its former location. 
Discharge measurements of Swiftcurrent Creek near Babb, Mont., in 1907 and 1908.

\begin{tabular}{|c|c|c|c|c|c|}
\hline Date. & Hydrographer. & Width. & $\begin{array}{l}\text { Area of } \\
\text { section. }\end{array}$ & $\begin{array}{c}\text { Gage } \\
\text { height. }\end{array}$ & $\begin{array}{c}\text { Dis- } \\
\text { charge. }\end{array}$ \\
\hline 1907. & & Feet. & $S q \cdot f t$ & Feet. & Sec. $-f t$. \\
\hline March 21 & W. S. Hanna... & $\cdots \cdots$ & 51 & 2.18 & 120 \\
\hline $\begin{array}{l}\text { May } 14 . . \\
\text { June } 6 \ldots\end{array}$ & J. B. Pierson.. & $\begin{array}{l}57 \\
62\end{array}$ & $\begin{array}{l}137 \\
181\end{array}$ & $\begin{array}{l}3.70 \\
4.85\end{array}$ & $\begin{array}{r}612 \\
1,460\end{array}$ \\
\hline July & .... do. . & 62 & 202 & 4.85 & 1.500 \\
\hline $\mathrm{Au}$ & ....do & 55 & 88 & 3.45 & 375 \\
\hline Se & and Pierson. & 54 & 94 & & 350 \\
\hline October $26 b \ldots$ & L. R. Stockman........ & 46 & 77 & 2.60 & 104 \\
\hline $\begin{array}{r}1908 . \\
\text { April } 18 . . .\end{array}$ & A. F. Huch........ & & 89.2 & 3.52 & \\
\hline July $26 b$. & Stewart and Huch.. & 70 & 107 & 3.45 & 408 \\
\hline Aug & & 62 & 94.7 & 3.12 & 250 \\
\hline $\mathrm{Au}$ & & 65 & 80 & 2.80 & 134 \\
\hline October 8 & A. F. Huch. & 60 & 74 & 2.67 & 95. \\
\hline
\end{tabular}

$a$ Ice along both shores.

$b$ Wading measurements.

Daily gage height, in feet, of Swiftcurrent Creek near Babb, Mont., for 1907 and 1908.

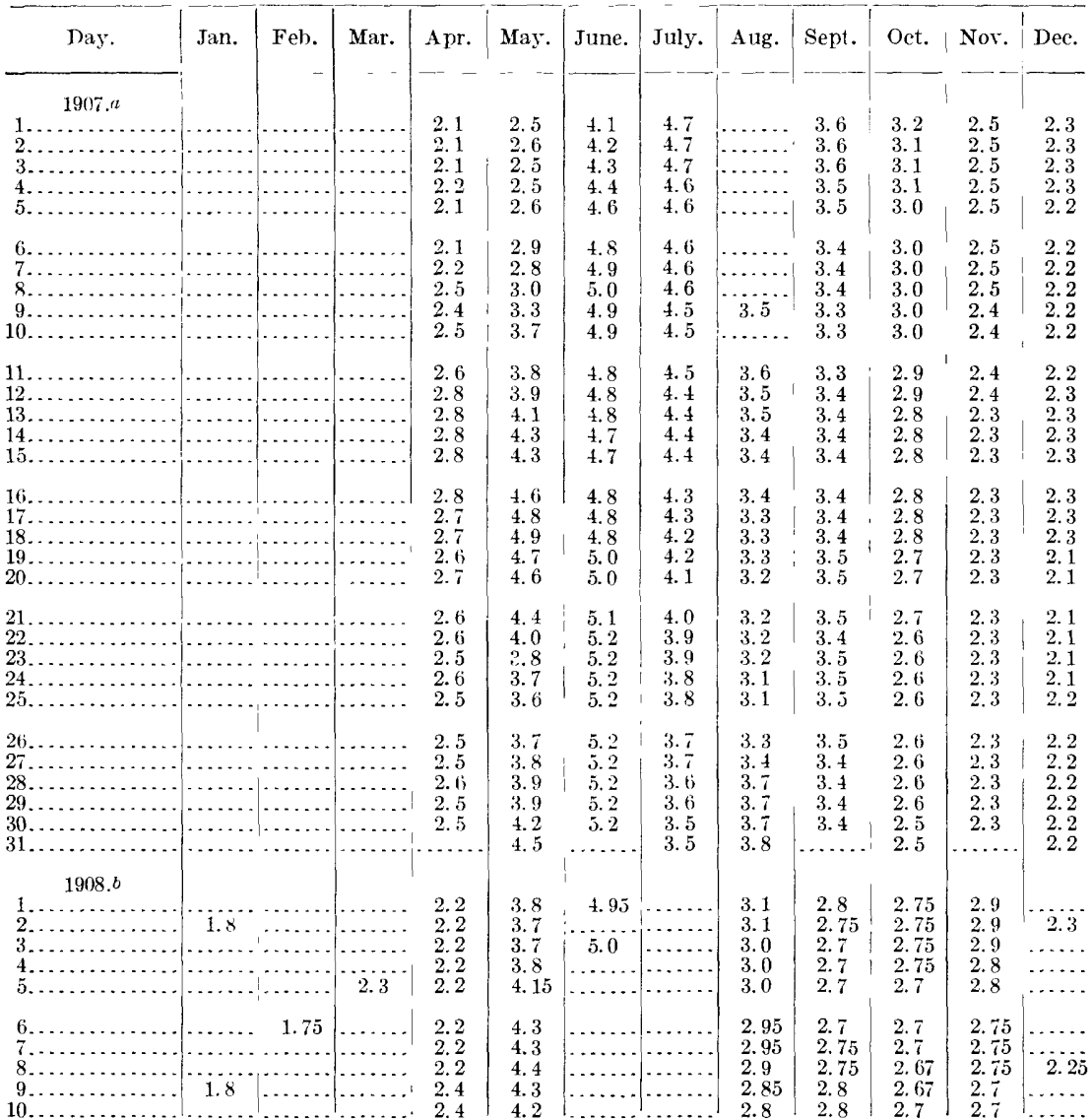

a Ice conditions prevailed from January 1 to about March 31, 1907.

$b$ Ice conditions prevailed from January 1 to about March 31 and from November 29 to December 31 , 1908. On June 4 the high water washed out both gage and cable. They were replaced July 26, 1908, the gage being located at a slightly different section. 
Daily gage height, in feet, of Swiftcurrent Creek near Babb, Mont., for $190 \%$ and 1908 -Continued.

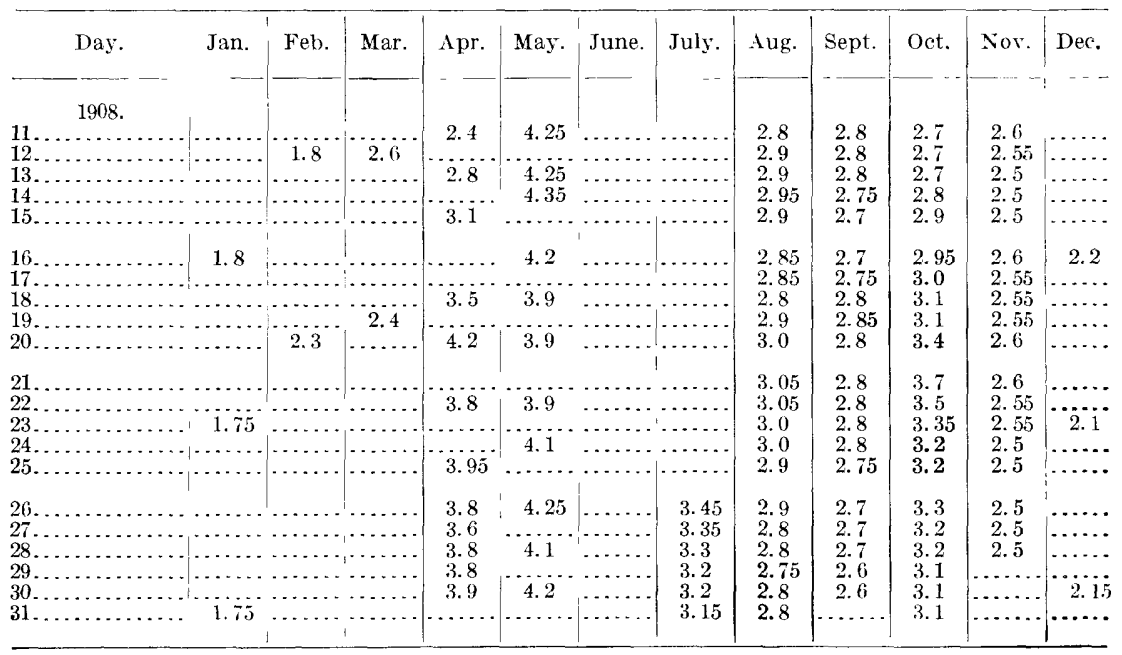

Rating tables for Swiftcurrent Creek near Babb, Mont.

JANUARY 1 TO MAY 31, 1907.

\begin{tabular}{|c|r|r|r|r|r|}
\hline $\begin{array}{c}\text { Gage } \\
\text { height. }\end{array}$ & $\begin{array}{c}\text { I is- } \\
\text { charge. }\end{array}$ & $\begin{array}{c}\text { Gage } \\
\text { height. }\end{array}$ & $\begin{array}{c}\text { Dis- } \\
\text { charge. }\end{array}$ & $\begin{array}{c}\text { Gage } \\
\text { height. }\end{array}$ & $\begin{array}{c}\text { Dis- } \\
\text { charge. }\end{array}$ \\
\hline & & & & & \\
\hline Feet. & Sec.ft. & Feet. & Sec.ft. & Feet. & Sec. $f t$. \\
2.10 & 90 & 3.10 & 310 & 4.10 & 850 \\
2.20 & 106 & 3.20 & 377 & 4.20 & 920 \\
2.30 & 124 & 3.30 & 417 & 4.30 & 995 \\
2.40 & 144 & 3.40 & 460 & 4.40 & 1,070 \\
2.50 & 166 & 3.50 & 506 & 4.50 & 1,150 \\
2.60 & 190 & 3.60 & 554 & 4.60 & 1,230 \\
2.70 & 216 & 3.70 & 605 & 4.70 & 1,320 \\
2.80 & 244 & 3.80 & 660 & 4.80 & 1,420 \\
2.90 & 274 & 3.90 & 720 & 4.90 & 1.520 \\
3.00 & 306 & 4.00 & 785 & 5.00 & 1,620 \\
& & & & & \\
\hline
\end{tabular}

NotE.-The above table is not applicable for ice or obstructed-channel conditions. It is based on two discharge measurements made during 1906 and two made during 1907 . It is not well defined.

JUNE 1, 1907, TO JUNE 3, 1908.

\begin{tabular}{|r|r||r|r|r|r|}
\hline $\begin{array}{c}\text { Gage } \\
\text { height. }\end{array}$ & $\begin{array}{c}\text { Dis- } \\
\text { charge. }\end{array}$ & $\begin{array}{c}\text { Gage } \\
\text { height. }\end{array}$ & $\begin{array}{c}\text { Dis- } \\
\text { charge. }\end{array}$ & $\begin{array}{c}\text { Gage } \\
\text { height. }\end{array}$ & $\begin{array}{c}\text { Dis- } \\
\text { charge. }\end{array}$ \\
& - & & & \\
Feet. & Sec.ft. & Feet. & Sec.-ft. & Feet. & Sec.-ft. \\
2.10 & 29 & 3.20 & 280 & 4.20 & 880 \\
2.20 & 39 & 3.30 & 321 & 4.30 & 965 \\
2.30 & 51 & 3.40 & 366 & 4.40 & 1,050 \\
2.40 & 65 & 3.50 & 415 & 4.50 & 1,140 \\
2.50 & 82 & 3.60 & 470 & 4.60 & 1,230 \\
2.60 & 102 & 3.70 & 530 & 4.70 & 1,320 \\
2.70 & 124 & 3.80 & 590 & 4.80 & 1,420 \\
2.80 & 149 & 3.90 & 655 & 4.90 & 1,520 \\
2.90 & 177 & 4.00 & 725 & 5.00 & 1.620 \\
3.00 & 208 & 4.10 & 800 & 5.20 & 1,840 \\
3.10 & 242 & & & & \\
\hline
\end{tabular}

NotE.-The above table is not applicable for ice or obstructed-channel conditions. It is based on five discharge measurements made during 1908 and is fairly well defined above gage height 2.5 feet. 
Rating tables for Swiftcurrent Creek near Babb, Mont.--Continued.

JULY 26 TO DECEMBER 31, 1908.

\begin{tabular}{|r|r||r|r|r|r|}
\hline $\begin{array}{c}\text { Gage } \\
\text { height. }\end{array}$ & $\begin{array}{c}\text { Dis- } \\
\text { charge. }\end{array}$ & $\begin{array}{c}\text { Gage } \\
\text { height. }\end{array}$ & $\begin{array}{c}\text { Dis- } \\
\text { eharge. }\end{array}$ & $\begin{array}{c}\text { Gage } \\
\text { height. }\end{array}$ & $\begin{array}{c}\text { Dis- } \\
\text { charge. }\end{array}$ \\
\hline Feet. & Sec. ft. & Feet. & Sec.-ft. & Feet. & Sec. ft. \\
2.20 & 21 & 2.80 & 133 & 3.30 & 329 \\
2.30 & 32 & 2.90 & 165 & 3.40 & 380 \\
2.40 & 45 & 3.00 & 200 & 3.50 & 434 \\
2.50 & 61 & 3.10 & 239 & 3.60 & 491 \\
2.60 & 80 & 3.20 & 282 & 3.70 & 551 \\
2.70 & 104 & & & & \\
\hline
\end{tabular}

Note. - The above table is not applicable for ice or obstructed-channel condilions. It is based on four discharge ineasurements made during 1908 after the establishment of the new gage and is well defined between gage heights $2 . \overline{\text { and }} 3.5$ feet.

Monthly discharge of Swiftcurrent Creek near Babb, Mont., for 190\% and 1908.

[Drainage area, 101 square miles.]

\begin{tabular}{|c|c|c|c|c|c|c|c|}
\hline \multirow[b]{2}{*}{ Month. } & \multicolumn{4}{|c|}{ Discharge in second-feet. } & \multicolumn{2}{|c|}{ Run-off. } & \multirow[b]{2}{*}{$\begin{array}{l}\text { Accu- } \\
\text { racy. }\end{array}$} \\
\hline & Maximum. & Minimum. & Mean. & $\begin{array}{l}\text { Per } \\
\text { square } \\
\text { mile. }\end{array}$ & $\begin{array}{c}\text { Depth in } \\
\text { inches on } \\
\text { drainage } \\
\text { area. }\end{array}$ & $\begin{array}{l}\text { Total in } \\
\text { acre feet. }\end{array}$ & \\
\hline 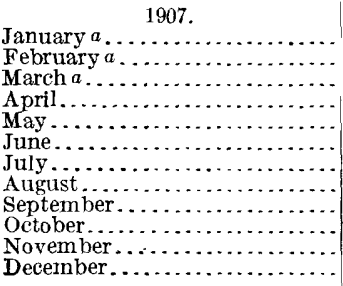 & $\begin{array}{r}244 \\
1,520 \\
1,840 \\
1,320 \\
590 \\
470 \\
280 \\
82 \\
51\end{array}$ & $\begin{array}{r}90 \\
90 \\
166 \\
800 \\
415 \\
242 \\
321 \\
82 \\
51 \\
29\end{array}$ & \begin{tabular}{r|}
50 \\
65 \\
50 \\
171 \\
713 \\
1,510 \\
912 \\
387 \\
387 \\
157 \\
61.1 \\
41.3
\end{tabular} & $\begin{array}{r}0.495 \\
.644 \\
.495 \\
1.69 \\
7.06 \\
15.0 \\
9.03 \\
3.83 \\
3.83 \\
1.55 \\
.605 \\
.409\end{array}$ & $\begin{array}{r}0.57 \\
.67 \\
.57 \\
1.89 \\
8.14 \\
16.69 \\
10.41 \\
4.42 \\
4.27 \\
1.79 \\
.68 \\
.47\end{array}$ & $\begin{array}{r}3,070 \\
3.610 \\
3,070 \\
10,200 \\
43,800 \\
89,800 \\
56,100 \\
23,800 \\
23,000 \\
9,650 \\
3,640 \\
2,540\end{array}$ & $\begin{array}{l}\text { D. } \\
\text { D. } \\
\text { D. } \\
\text { C. } \\
\text { B. } \\
\text { A. } \\
\text { A. } \\
\text { A. } \\
\text { A. } \\
\text { B. } \\
\text { C. } \\
\text { D. }\end{array}$ \\
\hline The year.............. & 1,840 & $\ldots \ldots \ldots \ldots$ & 375 & 3. 72 & 50.57 & 272,000 & \\
\hline 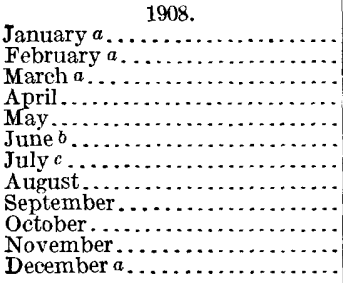 & $\begin{array}{r}880 \\
1,220 \\
730 \\
239 \\
149 \\
551 \\
165\end{array}$ & $\begin{array}{r}39 \\
530 \\
1,570 \\
260 \\
118 \\
80 \\
97 \\
35 \\
\ldots \ldots \ldots \ldots\end{array}$ & $\begin{array}{l}15 \\
25 \\
50 \\
333 \\
821 \\
1,940 \\
547 \\
171 \\
118 \\
208 \\
91.9 \\
18\end{array}$ & $\begin{aligned} .149 \\
.248 \\
.495 \\
3.30 \\
8.13 \\
19.2 \\
5.42 \\
1.69 \\
1.17 \\
2.06 \\
.910 \\
.178\end{aligned}$ & $\begin{array}{r}.17 \\
.27 \\
.57 \\
3.68 \\
9.37 \\
21.42 \\
6.25 \\
1.95 \\
1.30 \\
2.38 \\
1.02 \\
.21\end{array}$ & $\begin{array}{r}922 \\
1,440 \\
3,070 \\
19,800 \\
50,500 \\
115,000 \\
33,600 \\
10,500 \\
7,020 \\
12,800 \\
5,470 \\
1,110\end{array}$ & $\begin{array}{l}\text { D. } \\
\text { D. } \\
\text { D. } \\
\text { C. } \\
\text { B. } \\
\text { C. } \\
\text { C. } \\
\text { A. } \\
\text { A. } \\
\text { A. } \\
\text { A. } \\
\text { D. }\end{array}$ \\
\hline The year. & . & $\ldots .$. & 362 & 3.58 & 48.59 & 261,000 & \\
\hline
\end{tabular}

$a$ Ice conditions and discharge estimated.

$b$ Discharge obtained by using the same rate of run-off per square mile as St. Mary River near Babb.

$c$ July 1-25, 1908, obtained from comparative hydrographs of the three stations in this vicinity.

\section{RED RIVER DRAINAGE BASIN.}

\section{DESCRIPTION.}

Red River rises in Minnesota, its most remote source being a small lake near the southwest corner of Clearwater County, about 13 miles west of Lake Itasca, at an elevation of about 1,550 feet above sea level. From this point it flows south 60 miles (measured in a direct line) through a succession of small lakes to Ottertail Lake (elevation 
about 1,315 feet), and thence it flows westward 42 miles to Breckenridge, Minn., and Wahpeton, N. Dak. (elevation 943 feet). From this point it runs northward 285 miles, measured in a direct line, to the southern end of Lake Winnipeg, passing the Canadian boundary at Pembina at a distance of 190 miles and the city of Winnipeg at about 250 miles. On account of the meanderings of the river, the length of its channel is nearly double the length of the direct line.

Lake Winnipeg is about 250 miles long, and from its northern end Nelson River flows northeastward 400 miles to Hudson Bay.

The upper portion of Red River is called Ottertail River, that name being variously applied down as far as Ottertail Lake, Fergus Falls, or Breckenridge and Wahpeton as a lower limit; the portion flowing northward from Wahpeton to Lake Winnipeg is universally called Red River.

From Wahpeton to Lake Winnipeg the fall of the main portion of the river is small, the low-water elevation at Pembina being 750 feet, and the elevation of Lake Winnipeg 710 feet. From Wahpeton to Pembina the river forms the boundary between the States of Minnesota and North Dakota, and in this stretch it occupies the middle of the broad, smooth plain well known as the Red River valley. This plain is 40 to 50 miles wide and has no slope perceptible to the eye, the rise away from the river being only 3 to 6 feet to the mile. Red River valley was occupied during the glacial epoch by a lake, known to geologists as Lake Agassiz; at that time, the outlet to the north being filled by the ice sheet, the valley filled until the overflow passed away through Lake Traverse and Bigstone Lake into the head of Minnesota River, 65 miles south of Breckenridge. The whole district is now deeply covered with glacial drift, or, in the lake bottom, with an even layer of silt. No rock in place is found.

The principal tributaries of Red River are as follows: On the east side, Pelican, Buffalo, Wild Rice, Red Lake, and Snake rivers, and Two Rivers; on the west side, Bois des Sioux, Wild Rice, Sheyenne, Goose, Park, and Pembina rivers. The Bois des Sioux forms the Minnesota-North Dakota boundary from Wahpeton to the southeast corner of North Dakota, but is otherwise of no importance, being merely a prairie stream having very small flow except during a few weeks in the spring. These tributaries drain a district bounded on the south by the Minnesota River drainage area; on the east by the areas of the upper Mississippi River and of Rainy River (which flows into Lake Winnipeg); on the west by the area of James River (which flows into the Missouri), by the Devils Lake area (an inland basin), and by the area of Mouse River, which enters Red River at Winnipeg.

At the margins of this drainage area elevations range between 1,200 and 1,600 feet, but the boundaries are not precisely defined. Along much of the eastern side the country is so level that the 
numerous swamps and marshes drain with equal facility to either side; along the western side there are wide belts whose drainage systems were destroyed by the accumulation of drift and moraines left by the ice at the glacial epoch; and in these belts the surface water collects in innumerable hollows, kettle holes, and sloughs, and stands till it evaporates. If the rainfall were greater these many sinkholes and lakelets would overflow, and natural erosion would perfect the drainage system and make it again apparent to the eye. Large areas of swamp or undrained land are being gradully reclaimed by extensive artificial drainage systems, which have the effect of bringing the water more quickly to the stream after storms or the spring thaw; and it is possible that the regimen of some of the streams is being greatly altered by the construction of ditches.

So far as can be determined from the best existing maps the drainage area tributary to Red River above the point where it crosses the Canadian boundary at Pembina comprises about 34,500 square miles, of which 16,400 are in Minnesota, 500 in South Dakota, 15,600 in North Dakota, and 2,000 in Manitoba (in the Pembina River drainage area).

East of a north-and-south line drawn about 50 miles east of the main Red River, the whole country may be said to be heavily timbered; west of such a line it is open prairie, treeless except along the streams.

The mean annual rainfall of the Red River drainage area increases uniformly from east to west, being 15 to 18 inches at the western boundary; 19 to 24 inches at stations in the middle of the valley; and 24 to 26 inches at the eastern boundary. On account of the larger rainfall on the eastern side of the area the run-off per square mile from the tributaries on this side is from two to ten times as great as that from the tributaries on the west side. About 75 per cent of the total rainfall occurs in the six months from April 1 to September 30 .

The basin lies so far north that the streams are icebound from the middle of November until late in March or early in April, and the winter flow is small but uniform, for thaws sufficient to cause winter floods never occur. Destructive floods sometimes occur in the spring, however, if the snow accumulation is large and if the ground is frozen so deeply that little of the water percolates downward.

The headwaters of the tributaries on the eastern side, nearly every one of which passes through numerous lakes, afford many opportunities for inexpensive storage; on the west side a few localities for limited storage are also found on Pembina and Sheyenne rivers; on Red River itself below Breckenridge there is no opportunity for storage.

The lake-regulated tributaries on the eastern side also present opportunities for power development, and a number of power plants are now in operation; but the flow of the prairie tributaries from the 
west is so irregular that no important power development is possible without extensive storage to carry over the low-water periods of late summer, fall, and winter. On the Red below and above Fergus Falls, on the Pelican, the Wild Rice, the Red Lake, and the Clearwater, and on the smaller streams there are many other opportunities for profitable power development under heads of 10 to 25 feet.

Red Lake River and its tributaries are extensively used for logging, and some logging is also done on Wild Rice River.

Red River is navigable from Grand Forks down to Winnipeg. Theoretically it is navigable from Grand Forks up to Breckenridge except during low water, but in recent years there has been no traffic except in the lower 25 miles of this portion, and many fixed bridges have been cheaply built, practically closing it to navigation. Red Lake River is navigable in its lower course and also in the upper 40 miles, there being regular traffic from Thief River Falls to Red Lake.

The records of the gaging stations in this area provide data of value for general statistical and comparative use in questions involving the seasonal or total flow of the whole river or any of its tributaries. The chief questions that will arise on the main river involve the prevention of flood damage and navigation; on the tributaries, water power, flood damage, and opportunities for drainage development.

The following gaging stations have been maintained in this river basin:

Ottertail River near Fergus Falls, Minn., 1904-1908.

Red River at Fargo, N. Dak., 1901-1908.

Red River at Grand Forks, N. Dak., 1901-1908. (Gage height record 1895-1901.)

Red River at Emerson, Manitoba, 1902.

Sheyenne River at Haggart, N. Dak., 1902-1907.

Devils Lake near Devils Lake, N. Dak., 1901-1908.

Red Lake River at Crookston, Minn., 1901-1908.

Pembina River at Neche, N. Dak., 1903-1908.

Mouse River near Foxholm, N. Dak., 1904-1906.

Mouse River at Minot, N. Dak., 1903-1908.

Des Lacs River at Foxholm, N. Dak., 1904-1906.

\section{OTTERTAIL RIVER NEAR FERGUS FALLS, MINN.}

This station, which was established May 9, 1904, is located at Threemile Bridge, about $3 \frac{1}{2}$ miles northeast of Fergus Falls, Minn., but because of the loop in the river it is 8 miles higher up the valley than Fergus Falls.

The records furnish information of especial value in connection with the future development of water power, for which this stream is particularly available.

Ottertail Lake, which has an area of about 22 square miles, is 20 miles above the station, and this, with other smaller lakes farther above, steadies the flow. The recorded range of gage heights at the station is only 1.45 feet. 
The gravel channel at the station is remarkably permanent. There have been no changes in the gage datum or discharge curve since the establishment of the station, and the results are excellent for the entire open season. No records have been kept for the winter season, which lasts from about December 1 to April 1.

Discharge measurements of Ottertail River near Fergus Falls, Minn., in 1907 and 1908.

\begin{tabular}{|c|c|c|c|c|c|}
\hline Date. & IIydrographer. & Width. & $\begin{array}{l}\text { Area of } \\
\text { section. }\end{array}$ & $\begin{array}{c}\text { Gage } \\
\text { height. }\end{array}$ & $\begin{array}{l}\text { Dis- } \\
\text { charge. }\end{array}$ \\
\hline $\begin{array}{l}1907 . \\
\text { July } 19 \\
\text { August } 1 \ldots\end{array}$ & $\begin{array}{l}\text { E. F. Chandler ............ } \\
\text { Follansbee and Chandler. }\end{array}$ & $\begin{array}{c}\text { Feet. } \\
93 \\
92\end{array}$ & $\begin{array}{r}S q . f t . \\
197 \\
164\end{array}$ & \begin{tabular}{c|} 
Feet. \\
3.51 \\
3.26
\end{tabular} & $\begin{array}{r}\text { Sec. }-f t \text {. } \\
603 \\
427\end{array}$ \\
\hline $\begin{array}{l}1908 . \\
\text { June } 26 . \\
\text { October } 26 .\end{array}$ & $\begin{array}{l}\text { E. F. Chandler. . } \\
\text {. . . do . . . . . }\end{array}$ & $\begin{array}{l}92.5 \\
90\end{array}$ & $\begin{array}{r}243 \\
\cdot 136\end{array}$ & $\begin{array}{l}4.05 \\
2.97\end{array}$ & $\begin{array}{l}894 \\
293\end{array}$ \\
\hline
\end{tabular}

Daily gage height, in feet, of Ottertail River near Fergus Falls, Minn., for $190 \%$ and 1908.

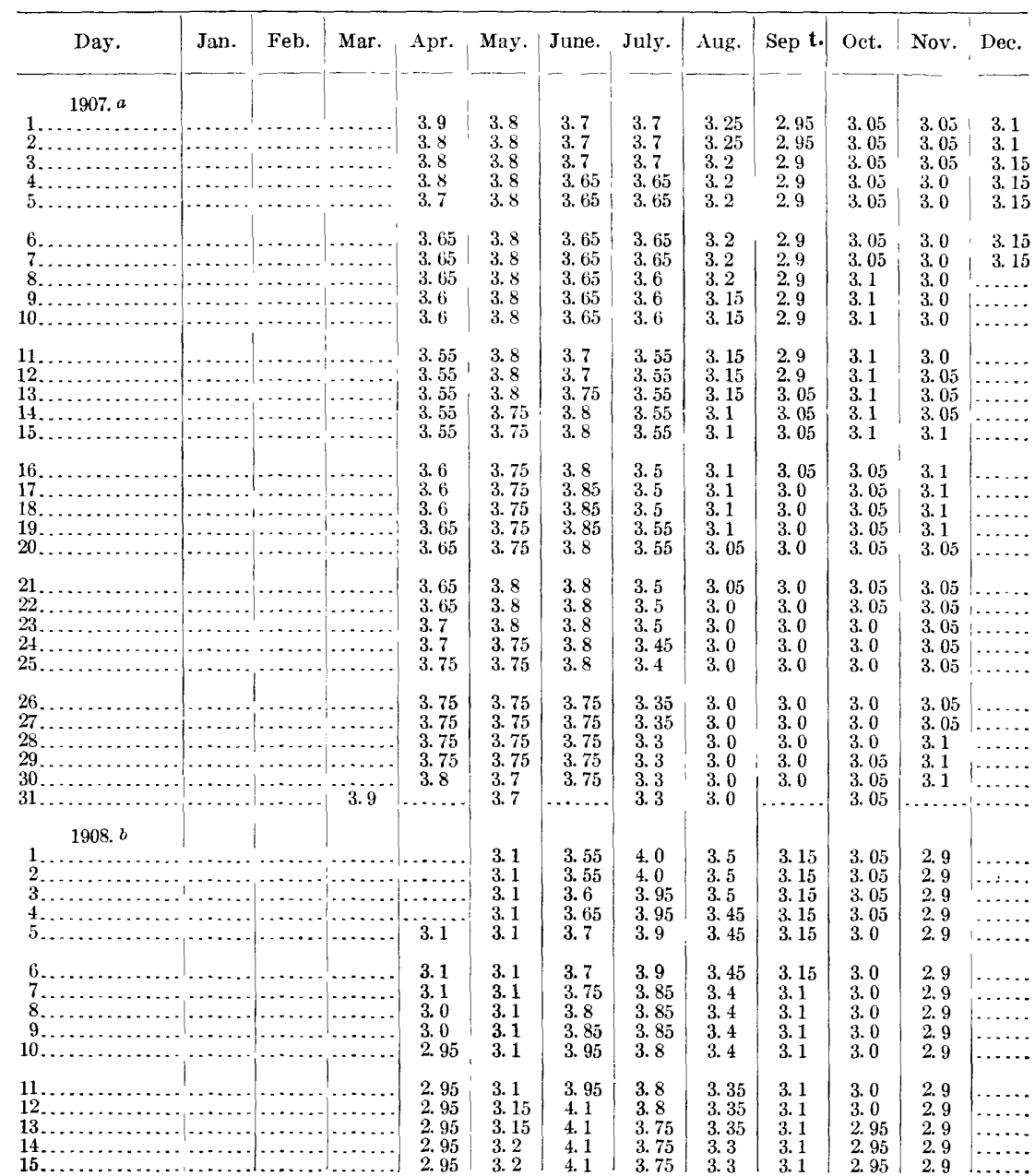


Daily gage height, in feet, of Ottertail River near Fergus Falls, Minn., for 1907 and 1908-Continued.

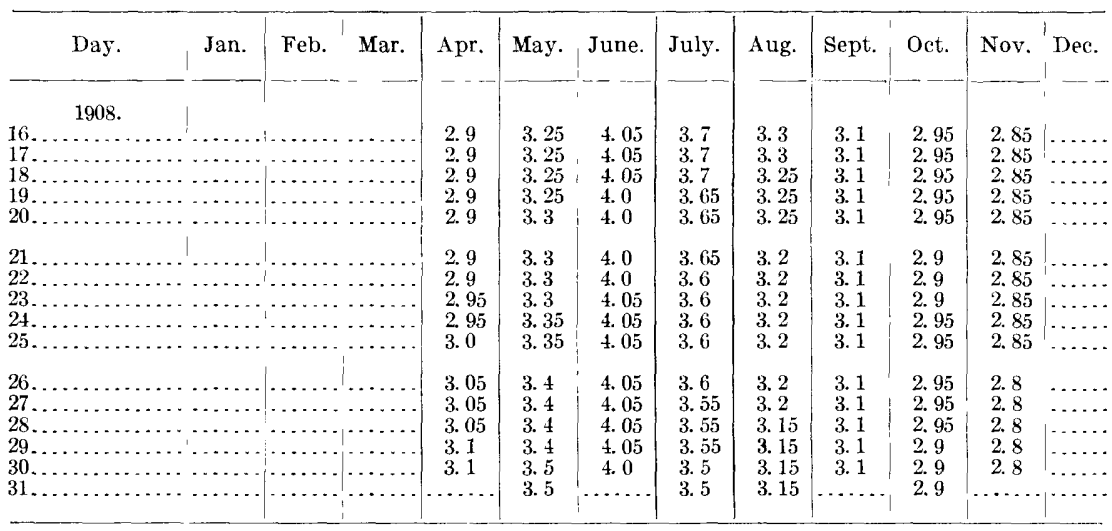

Rating table for Ottertail River near Fergus Falls, Minn., for 1905 to 1908.

\begin{tabular}{|r|r|r|r|r|r|r|r|}
$\begin{array}{r}\text { Gage } \\
\text { height. }\end{array}$ & $\begin{array}{c}\text { Dis- } \\
\text { charge. }\end{array}$ & $\begin{array}{c}\text { Gage } \\
\text { height. }\end{array}$ & $\begin{array}{c}\text { Dis- } \\
\text { charge. }\end{array}$ & $\begin{array}{c}\text { Gage } \\
\text { height. }\end{array}$ & $\begin{array}{c}\text { Dis- } \\
\text { charge. }\end{array}$ & $\begin{array}{c}\text { Gage } \\
\text { height. }\end{array}$ & $\begin{array}{c}\text { Dis- } \\
\text { charge. }\end{array}$ \\
\hline & & & & & & & \\
Fect. & Sec.ft. & Feet. & Sec.-ft. & Feet. & Sec.ft. & Feet. & Sec. $-f t$. \\
2.80 & 236 & 3.20 & 402 & 3.60 & 607 & 4.00 & 855 \\
2.90 & 274 & 3.30 & 449 & 3.70 & 665 & 4.10 & 921 \\
3.00 & 315 & 3.40 & 499 & 3.80 & 726 & & \\
3.10 & 357 & 3.50 & 552 & 3.90 & 789 & & \\
\hline
\end{tabular}

NotE.-The above table is not applicable for ice or obstructed-channel conditions. It is based on 14 discharge measurements made during 1904 to 1908 , and is well defined.

Monthly discharge of Ottertail River near Fergus Falls, Minn., for $190 \%$ and 1968.

[Drainage area 1,310 square miles.]

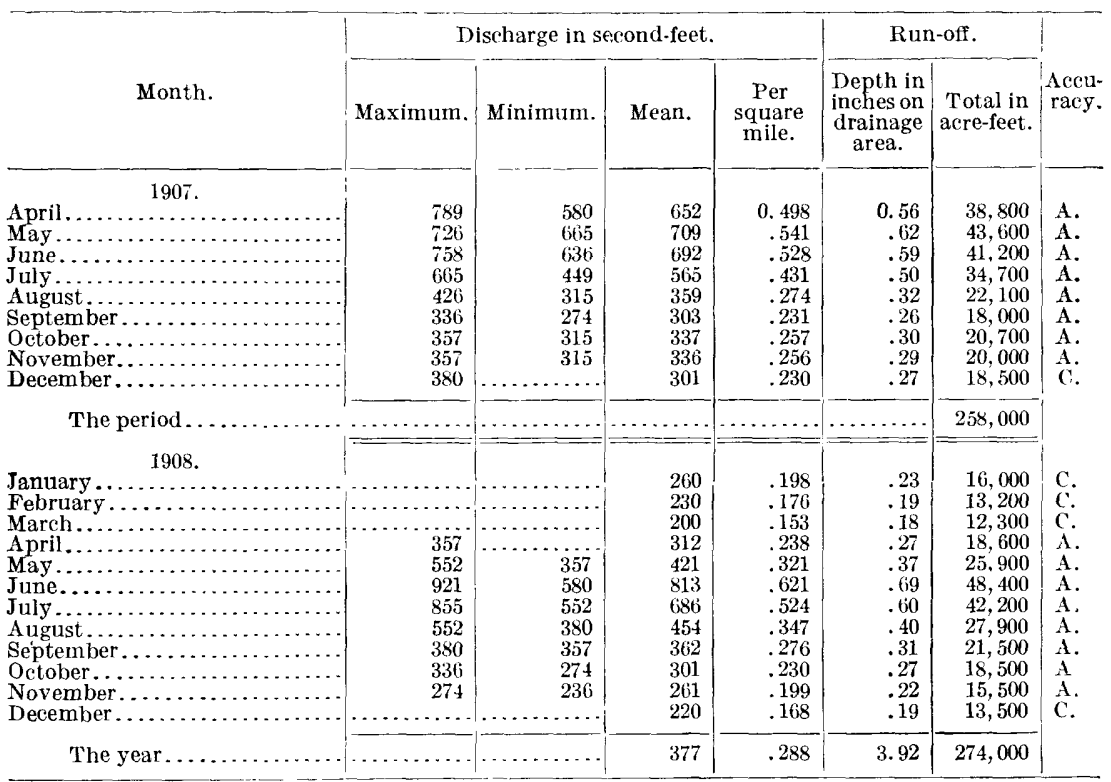

Note.--Ice conditions December 8-31, 1907; January 1 to A pril 5, and December 1-31, 1908. Diseharge has been estimated for these periods. 
RED RIVER AT FARGO, N. DAK.

This station, which is located at the highway bridge connecting Front street, Fargo, N. Dak., with Moorhead, Minn., was established May 23, 1901. Discharge measurements are made a half-mile farther upstream, at the footbridge at the Fargo waterworks pumping station, except at very high stage, when the Front Street Bridge or the Northern Pacific Railway bridge is used.

The drainage area above this station is about 6,020 square miles, 3,770 being in Minnesota, 500 in South Dakota, and 1,750 in North Dakota. The nearest tributary is Sheyenne River, which enters Red River, 10 miles below.

The gage datum has not been changed since the establishment of the station. The channel is in clay and silt, and slight changes in depth occur from time to time, but no large ones. The fall is so small that any accidental obstruction in the channel is likely to cause an appreciable effect for a long distance upstream, and to affect the rating. Hence, unless frequent discharge measurements are made slight errors will enter, but there have been no very great changes in the rating curves for eight years, and the records are fairly good except when affected by ice conditions.

The stream is smoothly closed by ice for about four months of the year. At the spring break-up, on account of the comparatively sluggish current and the fact that the river flows northward into a colder district, a pronounced backwater effect is usually caused by ice jams and partial ice jams, and the river is raised disproportionately high for several days or several weeks. At that season therefore the records can only be approximate unless daily discharge measurements are made.

Discharge measurements of Red River at Fargo, N. Dak., in 1907 and 1908.

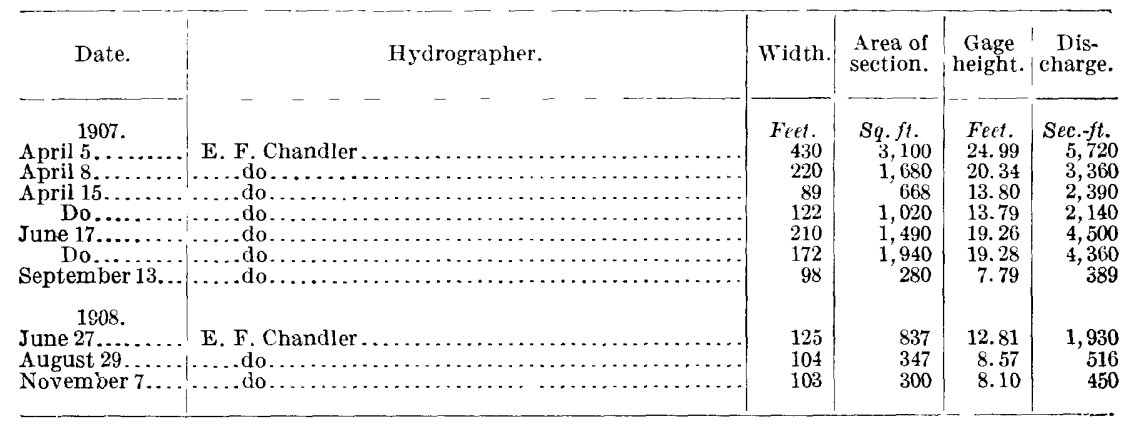

NuTE.-Measurements made at various sections. 
Daily gage height, in feet, of Red River at Fargo, N. Dak., for 1907 and 1908.

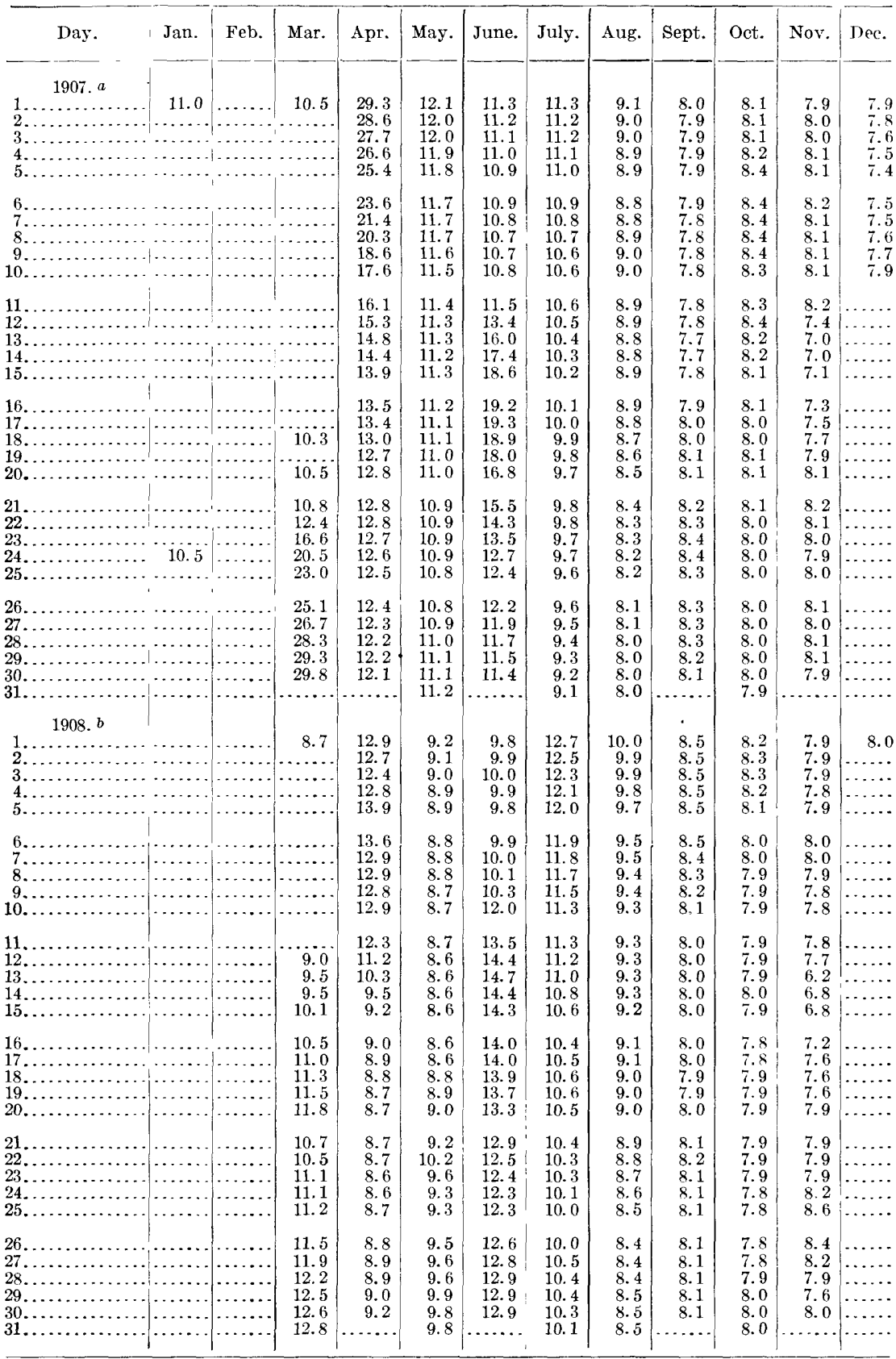

$a$ Ice conditions January to A pril, and December 10-31, 1907. There was considerable backwater during April due to ice gorges.

$b$ Ice conditions January 1 to April 6, and November 13 to December 31, 1908. 
Rating table for Red River at Fargo, N. Dak., for 1907 and 1908.

\begin{tabular}{|c|c|c|c|c|c|c|c|}
\hline $\begin{array}{c}\text { Gage } \\
\text { height. }\end{array}$ & $\begin{array}{c}\text { Dis- } \\
\text { charge. }\end{array}$ & $\begin{array}{c}\text { Gage } \\
\text { height. }\end{array}$ & $\begin{array}{c}\text { Dis- } \\
\text { charge. }\end{array}$ & $\begin{array}{c}\text { Gage } \\
\text { height. }\end{array}$ & $\begin{array}{c}\text { Dis- } \\
\text { charge. }\end{array}$ & $\begin{array}{c}\text { Gage } \\
\text { height. }\end{array}$ & $\begin{array}{c}\text { Dis- } \\
\text { charge. }\end{array}$ \\
\hline $\begin{array}{l}\text { Feet. } \\
7.00 \\
7.10 \\
7.20 \\
7.30 \\
7.40 \\
7.50 \\
7.60 \\
7.70 \\
7.80 \\
7.90 \\
8.00 \\
8.10 \\
8.20 \\
8.30\end{array}$ & $\begin{array}{r}\text { Sec. } f t . \\
220 \\
239 \\
258 \\
278 \\
298 \\
318 \\
339 \\
360 \\
381 \\
403 \\
425 \\
447 \\
469 \\
492\end{array}$ & $\begin{array}{l}\text { Feet. } \\
8.40 \\
8.50 \\
8.60 \\
8.70 \\
8.80 \\
8.90 \\
9.00 \\
9.10 \\
9.20 \\
9.30 \\
9.40 \\
9.50 \\
9.60 \\
9.70\end{array}$ & $\begin{array}{r}\text { Sec. } f t . \\
515 \\
539 \\
563 \\
588 \\
613 \\
639 \\
665 \\
691 \\
717 \\
744 \\
771 \\
799 \\
827 \\
856\end{array}$ & $\begin{array}{r}\text { Feet. } \\
9.80 \\
9.90 \\
10.00 \\
10.20 \\
10.40 \\
10.60 \\
10.80 \\
11.00 \\
11.20 \\
11.40 \\
11.60 \\
11.80 \\
12.00 \\
12.20\end{array}$ & $\begin{array}{r}\text { Sec.-ft. } \\
885 \\
915 \\
945 \\
1,008 \\
1,072 \\
1,137 \\
1,203 \\
1,270 \\
1,338 \\
1,406 \\
1,474 \\
1,542 \\
1,610 \\
1,679\end{array}$ & $\begin{array}{r}\text { Feet. } \\
12.40 \\
12.60 \\
12.80 \\
13.00 \\
14.00 \\
15.00 \\
16.00 \\
17.00 \\
18.00 \\
19.00 \\
20.00\end{array}$ & $\begin{array}{r}\text { Sec.-ft. } \\
1,749 \\
1,819 \\
1,889 \\
1,960 \\
2,330 \\
2,710 \\
3,100 \\
3,500 \\
3,900 \\
4,300 \\
4,700\end{array}$ \\
\hline
\end{tabular}

NoTE.-The above table is not applicable for ice or obstructed-channel conditions. It is based on discharge measurements made during 1901 to 1908 and is well defined between gage heights 7.0 feet and 20. 0 feet. Above gage height 16.0 feet the rating curve is a tangent, the difference being 40 per tenth.

Monthly discharge of Red River at Fargo, N. Dak., for 1907 and 1908.

[Drainage area, 6,020 square miles.]

\begin{tabular}{|c|c|c|c|c|c|c|c|}
\hline \multirow[b]{2}{*}{ Month. } & \multicolumn{4}{|c|}{ Discharge in second-feet. } & \multicolumn{2}{|c|}{ Run-off. } & \multirow[b]{2}{*}{$\begin{array}{l}\text { Accu- } \\
\text { racy. }\end{array}$} \\
\hline & Maximum. & Minimum. & Mean. & $\begin{array}{c}\text { Per } \\
\text { square } \\
\text { mile. }\end{array}$ & $\begin{array}{c}\text { Depth in } \\
\text { inches on } \\
\text { drainage } \\
\text { area. }\end{array}$ & $\begin{array}{c}\text { Total in } \\
\text { acre-feet. }\end{array}$ & \\
\hline 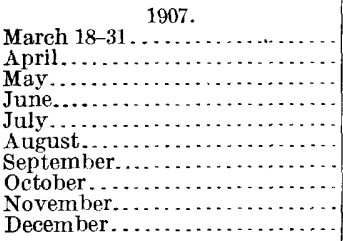 & $\begin{array}{r}1,640 \\
4,420 \\
1,370 \\
691 \\
515 \\
515 \\
469 \\
403\end{array}$ & $\begin{array}{r}1,200 \\
1,170 \\
691 \\
425 \\
360 \\
403 \\
220 \\
\ldots\end{array}$ & $\begin{array}{r}2,970 \\
2,920 \\
1,370 \\
2,200 \\
1,010 \\
568 \\
428 \\
456 \\
400 \\
315\end{array}$ & $\begin{array}{r}0.493 \\
.485 \\
.228 \\
.365 \\
.168 \\
.094 \\
.071 \\
.076 \\
.066 \\
.052\end{array}$ & $\begin{array}{l}0.26 \\
.54 \\
.26 \\
.41 \\
.19 \\
.11 \\
.08 \\
.09 \\
.07 \\
.06\end{array}$ & $\begin{array}{r}82,500 \\
174,000 \\
84,200 \\
131,000 \\
62,100 \\
34,900 \\
25,500 \\
28,000 \\
23,800 \\
19,400\end{array}$ & $\begin{array}{l}\text { B. } \\
\text { B. } \\
\text { A. } \\
\text { A. } \\
\text { A. } \\
\text { B. } \\
\text { B. } \\
\text { B. } \\
\text { B. } \\
\text { C. }\end{array}$ \\
\hline The period........ & $\ldots$ & & $\cdots$ & & $\ldots$. & 665,000 & \\
\hline 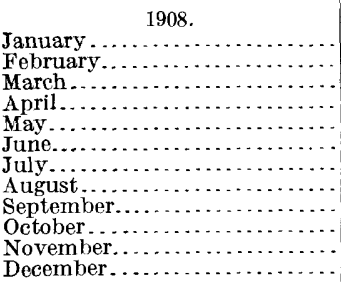 & $\begin{array}{r}1,010 \\
2,600 \\
1,850 \\
945 \\
539 \\
492 \\
450\end{array}$ & $\begin{array}{r}563 \\
563 \\
885 \\
945 \\
515 \\
403 \\
381 \\
\ldots \ldots \ldots\end{array}$ & $\begin{array}{r}290 \\
250 \\
500 \\
1,100 \\
691 \\
1,720 \\
1,230 \\
696 \\
462 \\
414 \\
360 \\
300\end{array}$ & $\begin{array}{l}.048 \\
.042 \\
.083 \\
.183 \\
.115 \\
.286 \\
.204 \\
.116 \\
.077 \\
.069 \\
.060 \\
.050\end{array}$ & $\begin{array}{l}.06 \\
.05 \\
.10 \\
.20 \\
.13 \\
.32 \\
.24 \\
.13 \\
.09 \\
.08 \\
.07 \\
.06\end{array}$ & $\begin{array}{r}17,800 \\
14,400 \\
30,700 \\
65,500 \\
42,500 \\
102,000 \\
75,600 \\
42,800 \\
27,500 \\
25,500 \\
21,400 \\
18,400\end{array}$ & $\begin{array}{l}\text { C. } \\
\text { C. } \\
\text { C. } \\
\text { B. } \\
\text { A. } \\
\text { A. } \\
\text { A. } \\
\text { A. } \\
\text { B. } \\
\text { B. } \\
\text { B. } \\
\text { C. }\end{array}$ \\
\hline The year....... & 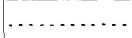 & & 668 & .111 & 1.55 & 484,000 & \\
\hline
\end{tabular}

NoTE.-Discharge estimated for March 18 to April 30, 1907, being based on three measurements. Also estimated for periods December 10, 1907, to April 6, 1908, and November 13 to December 31 , 1908.

\section{RED RIVER AT GRAND FORKS, N. DAK.}

This station is located at the Northern Pacific Railway bridge between Grand Forks, N. Dak., and East Grand Forks, Minn. It was established May 26, 1901, but gage height records had been kept for many years previously at the same point by the United States Engineers, whose gage datum is precisely 5.00 feet above the datum of the 
Geological Survey gage. Discharge measurements are usually made from the Great Northern Railway bridge, 1,000 feet above the gage.

The gage is one-half mile below the mouth of Red Lake River. The drainage area at this station includes about 13,420 square miles in Minnesota, 500 in South Dakota, and 11,080 in North Dakota, a total of $2 \dot{5,000}$ square miles. Red Lake River is the most important tributary, draining 5,680 square miles of the total area, and being much more steady in its flow than Red River, so that at low stages (in winter, and often in late summer and fall) Red Lake River brings from one-half to three-fifths of all the water passing this station. The datum of the gage has not been changed since its establishment. The channel is in clay and silt, and is subject to small gradual changes, but unusually precise gage records have been kept; the range of the river in height is so great-47 feet between the extremes of low and high water-that a change of 0.1 foot in gage height causes only a small percentage change in flow, and as frequent discharge measurements have been made the records are satisfactory, being as a rule excellent through the open season.

The river flows under smooth ice cover from about November 15 to April 10; the flow during the winter fluctuates little, and since 1895 enough discharge measurements have been made each winter to give fairly satisfactory summaries for the winter.

When the ice breaks up in the spring, because the river has only a gentle current and because it flows north into cooler regions where the river is not yet open, the gage reading is usually excessively and disproportionately high for a few days or weeks, so that the figures for quantity of flow must depend largely upon estimation; actual measurements when the river appeared entirely open and clear of ice at this point have sometimes shown the gage reading to be 5 feet greater than would have been needed for the same discharge later in the season, after the whole length of the river was entirely open.

Discharge measurements of Red River at Grand Forks, N. Dak., in 1907 and 1908.

\begin{tabular}{|c|c|c|c|c|c|}
\hline Date. & Hydrographer. & Width. & $\begin{array}{l}\text { Area of } \\
\text { section. }\end{array}$ & $\begin{array}{c}\text { Gage } \\
\text { height. }\end{array}$ & $\begin{array}{l}\text { Dis- } \\
\text { charge. }\end{array}$ \\
\hline 1907. & & Feet. & $S q \cdot f t$ & Feet. & Sec.ft. \\
\hline $\begin{array}{l}\text { January } 28 a \text {. } \\
\text { March } 4 a \ldots \ldots\end{array}$ & $\begin{array}{l}\text { E. F. Chandler. } \\
\text { W. H. Clark.... }\end{array}$ & $\begin{array}{l}195 \\
190\end{array}$ & $\begin{array}{l}852 \\
930\end{array}$ & $\begin{array}{l}8.07 \\
8.18\end{array}$ & $\begin{array}{l}1,180 \\
1,220\end{array}$ \\
\hline April 8. . & .....do. & 550 & 12,400 & 39.25 & 29,400 \\
\hline April 22. & E. F. Chandler.. & 240 & 3,510 & 19.37 & 8,740 \\
\hline November $11 b$. & $\ldots \ldots$ do $\ldots . . . .$. & 158 & 934 & 6.81 & 1,670 \\
\hline $\begin{array}{c}1908 . \\
\text { January } 20 a\end{array}$ & E. F. Chandler. & 140 & 641 & 6.76 & \\
\hline March & .....do.......... & 140 & 686 & 7.76 & \\
\hline Mare & ...do. & 23 & 2, & 14.16 & 3,680 \\
\hline April & .... do.. & 524 & 8,120 & 31.10 & 18,800 \\
\hline May & .... do. & 195 & 2,010 & 13.16 & 4,990 \\
\hline Jun & & 19 & 2,220 & 13.85 & 5,2 \\
\hline July & $\ldots \mathrm{dc}$ & 160 & 1,170 & 8.62 & 2,610 \\
\hline October 2 & .... do......... & 150 & 759 & 6.06 & 1,240 \\
\hline
\end{tabular}


Daily gage height, in feet, of Red River at Grand Forks, N. Dak., for 1907 and 1908.

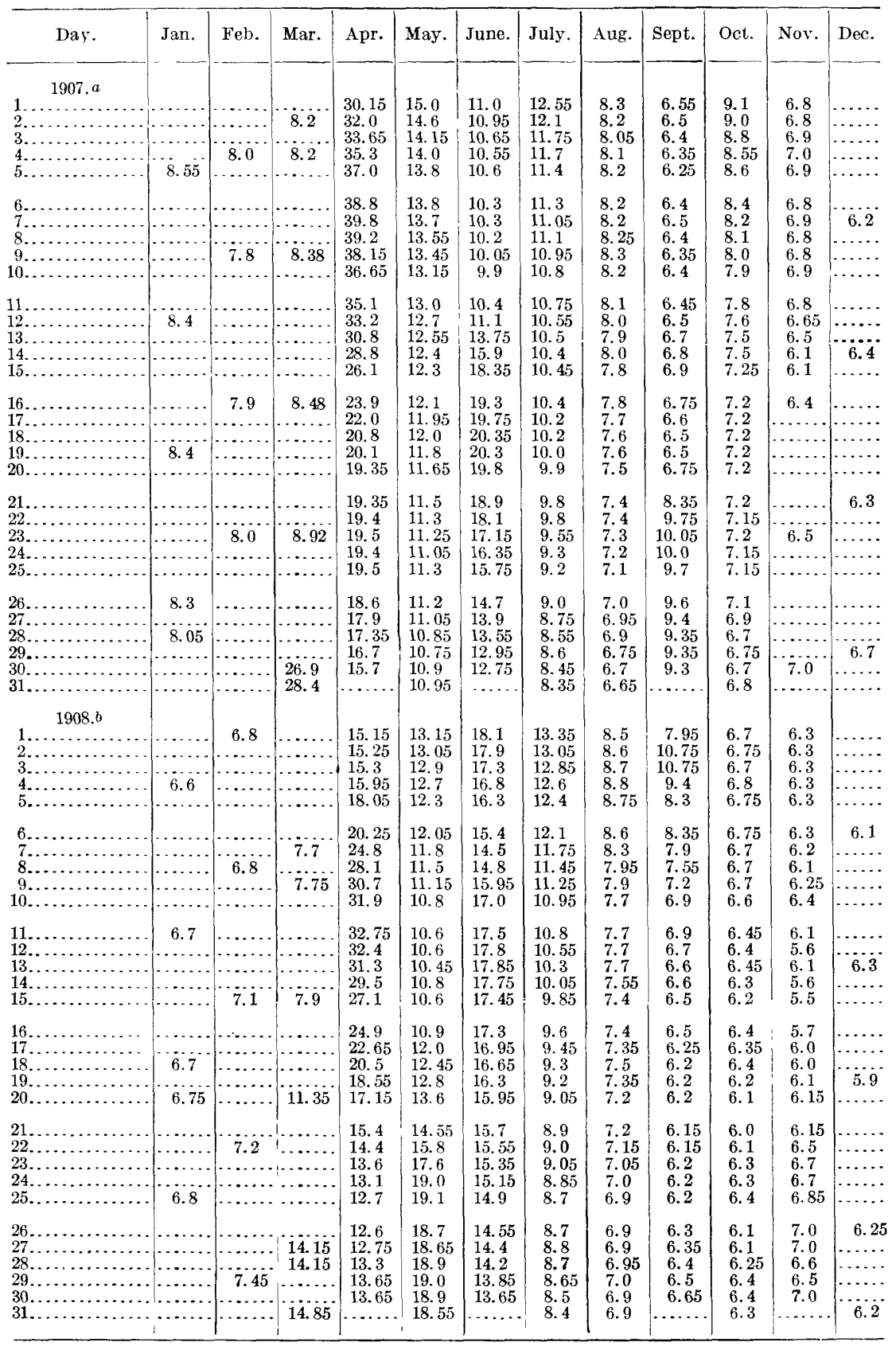

$a$ River frozen January 1 to April 4, and November 17 to December 31, 1907. Considerable backwater from ice gorging during April.

$b$ Ice conditions January 1 to April 4, and November 10 to December 31, 1908. 
Rating table for Red River at Grand Forks, N. Dak., for 1907 and 1908.

\begin{tabular}{|c|c|c|c|c|c|c|c|}
\hline $\begin{array}{c}\text { Gage } \\
\text { height. }\end{array}$ & $\begin{array}{l}\text { Dis- } \\
\text { charge. }\end{array}$ & $\begin{array}{l}\text { Gage } \\
\text { height. }\end{array}$ & $\begin{array}{c}\text { Dis- } \\
\text { charge. }\end{array}$ & $\begin{array}{c}\text { Gage } \\
\text { height. }\end{array}$ & $\begin{array}{c}\text { Dis- } \\
\text { charge. }\end{array}$ & $\begin{array}{c}\text { Gage } \\
\text { height. }\end{array}$ & $\begin{array}{c}\text { Dis- } \\
\text { charge. }\end{array}$ \\
\hline Feet. & Sec.-ft. & Feet. & Sec.-ft. & Feet. & Sec. $-f t$ & Feet. & Sec. $-f t$. \\
\hline 6.00 & 1,270 & 7.40 & 1,880 & 8.80 & 2,530 & 11.40 & 3,930 \\
\hline 6.10 & 1,310 & 7.50 & 1,925 & 8.90 & 2,580 & 11.60 & 4,050 \\
\hline 6.20 & 1,350 & 7.60 & 1,970 & 9.00 & 2,630 & 11.80 & 4,170 \\
\hline 6. 30 & 1,390 & 7.70 & 2,015 & 9.20 & 2,730 & 12.00 & 4,290 \\
\hline 6. 40 & 1,430 & 7. 80 & 2,060 & 9.40 & 2,830 & 13.00 & 4,920 \\
\hline 6.50 & 1,475 & 7.90 & 2,105 & 9.60 & 2,930 & 14.00 & 5.600 \\
\hline 6.60 & 1,520 & 8.00 & 2,150 & 9.80 & 3,030 & 15.00 & 6,300 \\
\hline 6.70 & 1,565 & 8.10 & 2,195 & 10.00 & 3,140 & 16.00 & 7,030 \\
\hline 6.80 & 1,610 & 8. 20 & 2,240 & 10.20 & 3,250 & 17.00 & 7,800 \\
\hline 6.90 & 1,655 & 8. 30 & 2,285 & 10.40 & 3,360 & 18.00 & 8,600 \\
\hline 7.00 & 1,700 & 8.40 & 2,330 & 10.60 & 3,470 & 19.00 & 9,430 \\
\hline 7.10 & 1,745 & 8.50 & 2,380 & 10.80 & 3,580 & 20.00 & 10,300 \\
\hline 7.20 & 1,790 & 8.60 & 2,430 & 11.00 & 3,690 & 21.00 & 11,190 \\
\hline 7. 30 & 1,835 & 8.70 & 2,480 & 11.20 & 3,810 & & \\
\hline
\end{tabular}

Note. - The above table is not applicable for ice or obstructed-channel conditions. It is based on 8 discharge measurements made during 1907 to 1909 and the form of the 1906 curve. It is well defined.

Monthly discharge of Red River at Grand Forks, N. Dak., for $190 \%$ and 1908.

[Drainage area, 25,000 square miles.]

\begin{tabular}{|c|c|c|c|c|c|c|c|}
\hline \multirow[b]{2}{*}{ Month. } & \multicolumn{4}{|c|}{ Discharge in second-feet. } & \multicolumn{2}{|c|}{ Run-off. } & \multirow{2}{*}{$\begin{array}{l}\text { Ac- } \\
\text { cura- } \\
\text { cy. }\end{array}$} \\
\hline & Maximum. & Minimum. & Mean. & $\begin{array}{l}\text { Per } \\
\text { square } \\
\text { mile. }\end{array}$ & $\begin{array}{l}\text { Depth in } \\
\text { inches on } \\
\text { drainage } \\
\text { area. }\end{array}$ & $\begin{array}{l}\text { Total in } \\
\text { acre-feet. }\end{array}$ & \\
\hline 1907. & & & & & & & \\
\hline 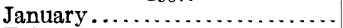 & & & 1,400 & 0.056 & 0,06 & 86,100 & C. \\
\hline February. & & & 1,090 & .044 & .05 & 60,500 & $\mathrm{C}$ \\
\hline 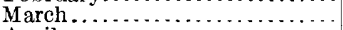 & 14,700 & 1,210 & 3,070 & .123 & .14 & 189,000 & $\mathrm{D}$. \\
\hline 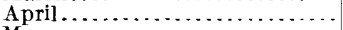 & 29,400 & 7,320 & 14,800 & .592 & .66 & 881,000 & B. \\
\hline 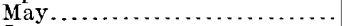 & 6,300 & 3,550 & 4,550 & .182 & .21 & 280,000 & A. \\
\hline June....................... & 10,600 & 3,080 & 6,000 & .240 & .27 & 357,000 & A. \\
\hline 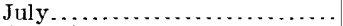 & 4,630 & 2,310 & 3,290 & .132 & .15 & 202,000 & A. \\
\hline 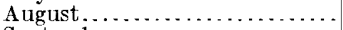 & 2,280 & 1,540 & 2,000 & .080 & .09 & 123,000 & A. \\
\hline 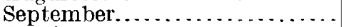 & 3,170 & 1,370 & 1,950 & .078 & .09 & 116,000 & A. \\
\hline 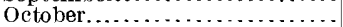 & 2,680 & 1,560 & 1,970 & .079 & .09 & 121,000 & A. \\
\hline November. & 1,700 & ....... & 1,440 & .058 & .06 & 85,700 & B. \\
\hline 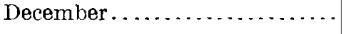 & & & 1,200 & .048 & .06 & 73,800 & $\overline{\mathrm{C}}$ \\
\hline The year. & . & $\mid \ldots \ldots \ldots$ & 3,560 & .143 & 1.93 & $2,580,000$ & \\
\hline 1908. & & & & & & & \\
\hline January $\ldots \ldots \ldots \ldots \ldots \ldots \ldots \ldots$ & ....... & $\ldots \ldots \ldots \ldots$ & 890 & .036 & .04 & 54,700 & C. \\
\hline 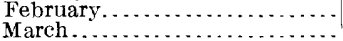 & $\cdots$ & $\cdots$ & 800 & .032 & .03 & 46,000 & C. \\
\hline $\begin{array}{l}\text { March ...... } \\
\text { April ..... }\end{array}$ & 20,500 & & 1,960 & .078 & .09 & 121,000 & C. \\
\hline May........ & 9,520 & 3,390 & $\begin{array}{l}9,850 \\
5,790\end{array}$ & $\begin{array}{r}.394 \\
.232\end{array}$ & .44 & $\begin{array}{l}586,000 \\
356,000\end{array}$ & B. \\
\hline 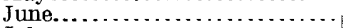 & 8,680 & 5,360 & $\begin{array}{l}5,190 \\
7,140\end{array}$ & $\begin{array}{l}.232 \\
.286\end{array}$ & .32 & $\begin{array}{l}000,000 \\
425,000\end{array}$ & $\begin{array}{l}\text { A. } \\
\text { A. }\end{array}$ \\
\hline 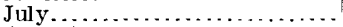 & 5,150 & 2,330 & 3,290 & .132 & .15 & 202,000 & A. \\
\hline August .......... & 2,530 & 1,660 & 1,970 & .079 & .09 & 121,000 & A. \\
\hline September.... & 3,550 & 1,330 & 1,760 & .070 & .08 & 105,000 & A. \\
\hline October...... & 1,610 & 1,270 & 1,440 & .058 & .07 & 88,500 & A. \\
\hline November.... & 1,390 & $\ldots \ldots \ldots$ & 1,250 & .050 & .06 & 74,400 & C. \\
\hline December... & $\cdots$ & $\cdots$ & 830 & .033 & .04 & 51,000 & C. \\
\hline The year. & 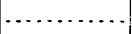 & & 3,080 & .123 & 1. 68 & $2,230,000$ & \\
\hline
\end{tabular}

Note.-Tce conditions January 1 to April 4 and November 17 to December 31,1907 ; January 1 to $\mathbf{A}$ pril 4 and November 10 to December 31,1908. There was considerable backwater due to ice gorging during $A$ pril, 1907. Discharges for ice periods have been estimated on the basis of ice measurements made.

$$
22110 \text {-IRR } 245-10-4
$$




\section{SHEYENNE RIVER AT HAGGART, N. DAK.}

This station is located at a private wagon bridge about one-fourth mile north of the railway at Haggart, on the Northern Pacific Railway, 6 miles west of Fargo, N. Dak. The station was established March 22, 1902, and discontinued July 1, 1907.

Sheyenne River rises in the central portion of North Dakota, 175 miles northwesterly from this station, and flows easterly, passing only a few miles south of Devils Lake and Stump Lake. These are now inland basins, but in recent geologic times of greater precipitation they overflowed and drained regularly into Sheyenne River. At this point the river turns south, then around in a wide curve to the east, and then north to the station, and empties into the Red River 10 miles below this station. The length along the general course of its valley is 330 miles. Its most important tributary, Maple River, is received 3 miles below this station.

The theoretical drainage area above the mouth of the Sheyenne River is about 6,930 square miles, and above this station is about 5,400 square miles. But the whole basin is within the glacial area of rolling prairie, drift covered in irregular slopes and ridges with imperfect drainage systems, so that it is probable that there is half to three-fourths of the entire drainage area from which no water ever reaches the river except in years of unusually large or sudden rainfall.

There has been no change in the gage datum. The station conditions, such as the sluggish character of the stream and large effect therefore caused by small temporary obstructions, the silting channel, and the possible occasional effect of backwater from the inflow of the Maple River 3 miles below, make it impossible to maintain precise records without frequent measurements, but the summaries are fairly correct.

The following discharge measurement was made April 8, 1907 :

Width, 67 feet; area, 346 square feet; gage height, 9.31 feet: discharge, 652 secondfeet. Ice was running at the time of measurement.

Daily gage height, in feet, of Sheyenne River at Haggart, N. Dak., for 190\%.

\begin{tabular}{|c|c|c|c|c|c|c|c|c|c|c|c|}
\hline Day. & April. & May. & June. & Day. & April. & May. & June. & Day. & April. & May. & June. \\
\hline $\begin{array}{l}1 \ldots \ldots \\
2 \ldots \ldots \\
3 \ldots \ldots \\
4 \ldots \ldots \\
5 \ldots \ldots\end{array}$ & $\begin{array}{l}18.2 \\
17.6 \\
15.2 \\
13.8 \\
11.2\end{array}$ & $\begin{array}{l}7.0 \\
7.4 \\
7.7 \\
8.2 \\
8.4\end{array}$ & $\begin{array}{l}5.6 \\
5.5 \\
5.4 \\
5.4 \\
5.3\end{array}$ & $\begin{array}{l}11 \ldots . . \\
12 \ldots \\
13 \ldots \\
14 \ldots \\
15 \ldots\end{array}$ & $\begin{array}{l}9.1 \\
8.5 \\
8.2 \\
7.6 \\
7.2\end{array}$ & $\begin{array}{l}7.4 \\
7.3 \\
7.1 \\
7.0 \\
6.7\end{array}$ & $\begin{array}{l}5.3 \\
5.6 \\
6.0 \\
6.0 \\
5.7\end{array}$ & $\begin{array}{l}21 \ldots \\
22 \ldots \\
23 \ldots \\
24 \ldots \\
25 \ldots\end{array}$ & $\begin{array}{l}6.4 \\
6.4 \\
6.4 \\
6.3 \\
6.3\end{array}$ & $\begin{array}{l}6.4 \\
6.4 \\
6.4 \\
6.3 \\
6.3\end{array}$ & $\begin{array}{l}5.8 \\
5.7 \\
5.6 \\
5.5 \\
5.4\end{array}$ \\
\hline $\begin{array}{r}6 \ldots \ldots \\
7 \ldots \ldots \\
8 \ldots \ldots \\
9 \ldots \ldots \\
10 \ldots \ldots\end{array}$ & $\begin{array}{l}9.8 \\
9.8 \\
9.4 \\
9.4 \\
9.3\end{array}$ & $\begin{array}{l}8.4 \\
8.3 \\
8.1 \\
7.7 \\
7.5\end{array}$ & $\begin{array}{l}5.3 \\
5.3 \\
5.2 \\
5.2 \\
5.1\end{array}$ & $\begin{array}{l}16 \ldots \\
17 \ldots \\
18 \ldots \\
19 \ldots \\
20 \ldots\end{array}$ & $\begin{array}{l}6.7 \\
6.6 \\
6.5 \\
6.5 \\
6.4\end{array}$ & $\begin{array}{l}6.7 \\
6.6 \\
6.6 \\
6.5 \\
6.5\end{array}$ & $\begin{array}{l}5.6 \\
5.4 \\
5.5 \\
5.7 \\
5.8\end{array}$ & $\begin{array}{l}26 \ldots . . \\
27 \ldots \\
28 \ldots \\
29 \ldots \\
30 \ldots \\
31 \ldots \ldots\end{array}$ & $\begin{array}{r}6.3 \\
6.3 \\
6.3 \\
6.3 \\
6.5\end{array}$ & $\begin{array}{l}6.2 \\
6.2 \\
6.1 \\
6.1 \\
6.0 \\
5.7\end{array}$ & $\begin{array}{r}5.4 \\
5.3 \\
5.3 \\
5.3 \\
5.2 \\
\ldots \ldots . .\end{array}$ \\
\hline
\end{tabular}

Note.-Floating ice from April 1 to 8. 
Rating table for Sheyenne River at Haggart, N. Dak., for 1905 to $190 \%$.

\begin{tabular}{|c|c|c|c|c|c|}
\hline $\begin{array}{c}\text { Gage } \\
\text { height. }\end{array}$ & $\begin{array}{c}\text { Dis- } \\
\text { charge. }\end{array}$ & $\begin{array}{c}\text { Gage } \\
\text { height. }\end{array}$ & $\begin{array}{c}\text { Dis- } \\
\text { charge. }\end{array}$ & $\begin{array}{c}\text { Gage } \\
\text { height. }\end{array}$ & $\begin{array}{c}\text { Dis- } \\
\text { charge. }\end{array}$ \\
\hline Feet. & Sec.-feet. & Feet. & Sec.-feet. & Feet. & Sec--feet. \\
5.00 & 200 & 5.30 & 233 & 5.60 & 269 \\
5.10 & 211 & 5.40 & 245 & 5.70 & 281 \\
5.20 & 222 & 5.50 & 257 & & \\
\hline
\end{tabular}

Note.-The above table is not applicable for ice or obstructed channel conditions. It is based on discharge measurements made during 1902 to 1906 and is fairly well defined. Above gage height 5.7 feet the rating curve is a tangent, the difference being 13 per tenth.

Monthly discharge of Sheyenne River at Haggart, N. Dak., for 190\%.

[Drainage area, 5,400 square miles.]

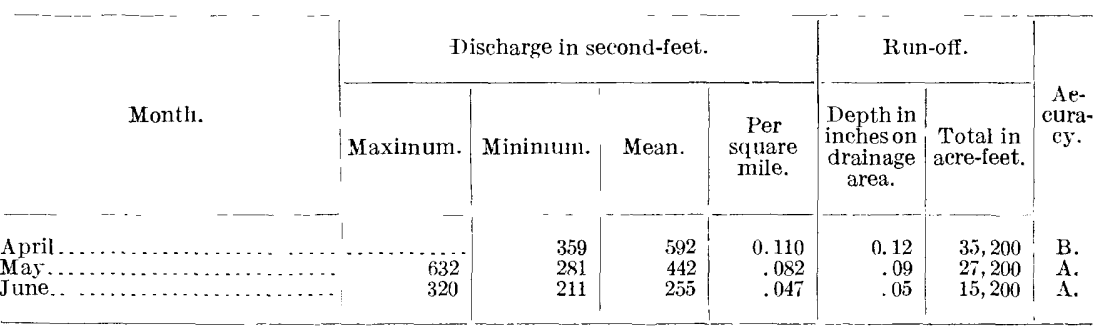

DEVILS LAKE AT DEVILS LAKE, N. DAK.

Devils Jake, in the north-central portion of North Dakota, offers an interesting example of the rainfall-evaporation-run-off ratio. This lake has no outlet, its surface elevation depending entirely upon the relation between evaporation from its surface, the rainfall upon it, and inflow from the surrounding country.

On the south the lake is borlered by hills 100 to 200 feet in height, and it is not far to the divide between the Devils Lake drainage area and the valley of Sheyenne River, which flows nearly parallel to the lake on the south at a distance of 6 to 12 miles. On the north a gently rolling prairie rises gradually, and on the northwest no other drainage area is reached for a distance of more than 50 miles. The total area draining to Devils Lake is theoretically somewhat more than 1,900 square miles.

This area is all included within the region covered by glacial drift; and small lakes, hollows, and pools are thickly scattered over it. The fall is slight, nearly the whole area being included between the elevations of 1,440 and 1,600 feet above sea level. The rainfall is but little in excess of the evaporation, the total run-off for the entire year as found at river stations in this State being rarely more than 2 inches, and often only a fraction of 1 inch, as computed from the theoretical drainage areas. With so small run-off and so small fall, the drainage channels and river systems are therefore as yet very imperfectly developed. Much of the water that runs into the small lakes or col 'ses is held there until it evaporates, and from large por- 
tions of the total drainage area no water ever reaches Devils Lake except in years of exceptionally great or sudden rainfall. The area which actually drains into Devils Lake in ordinary years is probably not more than a third or a half of the theoretical 1,900 square miles.

When the region was first settled, about twenty-five years ago, the surveys showed Devils Lake to have a total length of 35 miles, a width ranging from 1 mile to 15 miles, and an area of approximately 120 square miles; on account of its many bays and slender arms, the total shore line measured more than 200 miles. With settlement and the conversion into farms of the prairies formerly tenanted by vast herds of buffalo, the sod was broken, the soil cultivated, and the flow of rainfall from its surface retarded. The lake thus lost a large portion of its annual supply, and its level was continuously lowered by evaporation, until the reduction in surface area had brought the evaporation to equality with the inflow. The present area of the lake is not precisely known, but is estimated as not more than a half of the 120 square miles formerly seen. The lake seems to be now approximately in a condition of equilibrium, which ought to be maintained unless some change in the extent or method of agriculture should use still more fully the water that otherwise would run into the lake from the surrounding country.

It is a shallow lake, the greatest depth found at present stage being said to be only about 30 feet. Many old beaches are seen surrounding it at elevations of from 15 to 30 feet above the present surface; at a still farther elevation of a few feet, it is said that the lake would overflow the rim of its basin at the eastern end and find outlet into Stump Lake or Sheyenne River. It is certain that the lake had an outlet in some direction in quite recent geologic times, for the waters, though quite saline and brackish, have as yet small solid content compared with many such lakes, containing slightly more than 1 per cent by weight of the salts of sodium, calcium, and magnesium, or only one-third as much as ordinary sea water.

Since June 8, 1901, a gage has been maintained on Devils Iake by the United States Geological Survey, the same being a staff gage attached to the piles of the pier at the Chautauqua grounds steamer landing, 6 miles southwest of the city of Devils Lake. This gage is read occasionally by Capt. E. E. Heerman.

A standard United States Geological Survey bench mark post is set in the bank directly behind the gage and about 8 rods distant. The gage zero is $1,416.2$ feet above sea level, and the bench mark is 22.90 feet above the gage zero.

Descriptions of this station were published with some records, in Water-Supply Papers No. 66, page 14, and No. 85, page 238, except that the elevation of the bench mark above the gage zero as previously published is in error. 
The normal rainfall over the area draining into Devils Lake is between 15 and 18 inches a year, according to the more or less extended records of Weather Bureau stations, five in number, in or at the margins of the area, taken in comparison with others near by in adjoining areas. At each of these stations nearly complete rainfall records have been at some time maintained for a period of at least ten years.

The list of observed gage heights of the water surface of the lake since the establishment of the gage, with a few fairly well authenticated previous records, is given below:

Gage height, in feet, of Devils Lake near Devils Lake, N. Dak.

\begin{tabular}{|c|c|c|c|}
\hline Date. & $\begin{array}{l}\text { Gage } \\
\text { height. }\end{array}$ & Date. & $\begin{array}{c}\text { Gage } \\
\text { height. }\end{array}$ \\
\hline & Feet. & 1904 & Feet. \\
\hline$\ldots \ldots \ldots \ldots \ldots \ldots$, & 26.75 & April 24 & 12.7 \\
\hline$\ldots \ldots \ldots \ldots$ & 22.9 & April $30 \ldots$ & 12.8 \\
\hline 1896 , August & 13.0 & 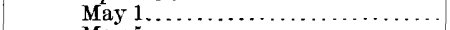 & 12.7 \\
\hline $1901-$ & & $\ldots \ldots \ldots \ldots \ldots \ldots \ldots$ & 12.75 \\
\hline June $7 \ldots \ldots \ldots \ldots \ldots \ldots \ldots \ldots$ & 12.15 & $\ldots \ldots \ldots \ldots \ldots$ & 12.8 \\
\hline June $8 \ldots \ldots \ldots \ldots \ldots \ldots$ & 12.4 & $\ldots \ldots \ldots \ldots \ldots \ldots \ldots \ldots$ & 13.2 \\
\hline June $23 \ldots \ldots \ldots \ldots \ldots \ldots$ & 12.35 & $\ldots \ldots \ldots \ldots \ldots$ & 13.4 \\
\hline . & 12.25 & June $20 \ldots \ldots \ldots \ldots \ldots$ & 13.4 \\
\hline August 17 & 12.05 & July 5. & 13.4 \\
\hline$\ldots \ldots \ldots \ldots$ & 11.9 & August 23 . & 13.0 \\
\hline September $19 \ldots \ldots \ldots \ldots \ldots \ldots$ & 11.65 & September $6 \ldots \ldots \ldots \ldots \ldots \ldots$ & 13.0 \\
\hline September $26 \ldots \ldots \ldots \ldots \ldots \ldots \ldots$ & 12.15 & October $3 \ldots \ldots \ldots \ldots \ldots \ldots \ldots$ & 12.8 \\
\hline October $8 \ldots \ldots \ldots \ldots \ldots \ldots \ldots \ldots$ & 12.1 & $\ldots \ldots \ldots \ldots \ldots$ & 12.75 \\
\hline October $21, \ldots \ldots \ldots \ldots \ldots \ldots$ & 12.05 & November $29 \ldots \ldots \ldots \ldots \ldots$ & 12.65 \\
\hline $1902-$ & & $1905-$ & \\
\hline April 25 & 13.55 & July 15 & 13.3 \\
\hline$\ldots \ldots \ldots \ldots \ldots$ & 13.6 & July 16 . & 13.5 \\
\hline May $5 \ldots \ldots \ldots \ldots \ldots \ldots \ldots \ldots \ldots$ & 13.8 & November $29 \ldots \ldots \ldots \ldots \ldots \ldots$. & 12.65 \\
\hline 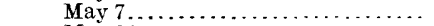 & 13.85 & $1900-$ & \\
\hline May $24 \ldots \ldots \ldots \ldots \ldots \ldots \ldots$ & 13.95 & April 8. & 12.8 \\
\hline June $5 \ldots \ldots \ldots \ldots \ldots \ldots \ldots \ldots$ & 14.0 & 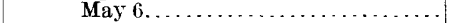 & 12.65 \\
\hline June $10 \ldots \ldots \ldots \ldots \ldots \ldots \ldots$ & 13.95 & $\ldots \ldots \ldots \ldots \ldots \ldots \ldots$ & 13.0 \\
\hline June $13 \ldots \ldots \ldots \ldots \ldots \ldots \ldots$. & 14.1 & June 21 & 12.95 \\
\hline June $22 \ldots \ldots \ldots \ldots \ldots \ldots$ & 14.0 & July 8. & 13.0 \\
\hline June $27, \ldots \ldots \ldots \ldots \ldots \ldots$ & 13.95 & August 22 . & 12.4 \\
\hline . $\ldots \ldots \ldots \ldots \ldots \ldots$ & 13.7 & Septem ber 24 . & 12.15 \\
\hline August $7 \ldots \ldots \ldots \ldots \ldots \ldots \ldots$ & 13.5 & October $11 \ldots$ & 11.85 \\
\hline August $23 \ldots \ldots \ldots \ldots \ldots \ldots \ldots$ & 13.7 & November $16 . \ldots \ldots \ldots \ldots \ldots$ & 11.6 \\
\hline September $13 \ldots \ldots \ldots \ldots \ldots$ & 13.2 & $1907-$ & \\
\hline September $28 \ldots \ldots \ldots \ldots \ldots$ & 13.2 & May 7 & 12.35 \\
\hline October $12 \ldots \ldots \ldots \ldots \ldots \ldots$ & 13.1 & June 2 . & 12.35 \\
\hline October $22 \ldots \ldots \ldots \ldots \ldots \ldots \ldots$ & 13.05 & July 1. & 12.4 \\
\hline November $15, \ldots \ldots \ldots \ldots \ldots . . . .$. & 13.0 & July 9 & 12.5 \\
\hline $1903-$ & & Jul & 12.3 \\
\hline$\ldots \ldots \ldots \ldots \ldots$ & 13.1 & August & 12.1 \\
\hline$\ldots \ldots \ldots \ldots$ & 13.1 & Iugust 8. & 11.95 \\
\hline$\ldots \ldots \ldots \ldots$ & 13.1 & August 28 . & 11.8 \\
\hline June 17 . & 12.9 & November $15 .$. & 11.3 \\
\hline$\ldots \ldots \ldots \ldots \ldots$ & 12.8 & $1908-$ & \\
\hline$\ldots \ldots \ldots \ldots \ldots$ & 12.6 & April 21. & 11.7 \\
\hline$\ldots \ldots \ldots \ldots \ldots \ldots$ & 12.55 & June $27 \ldots .$. & 11.35 \\
\hline July $19, \ldots \ldots \ldots \ldots \ldots \ldots \ldots \ldots$ & 12.4 & July 12. & 11.3 \\
\hline$\ldots \ldots \ldots \ldots \ldots \ldots$ & 12.3 & $\ldots \ldots \ldots \ldots \ldots \ldots$ & 11.2 \\
\hline$\ldots \ldots \ldots \ldots \ldots$ & 12.2 & August $3 \ldots$ & 11.1 \\
\hline Augu & 12.1 & August $12 \ldots$ & 10.9 \\
\hline August 29 . & 12.2 & August 20 . & 10.8 \\
\hline September $10 \ldots \ldots \ldots \ldots \ldots \ldots$ & 12.1 & August 29. & $10-7$ \\
\hline$\ldots \ldots \ldots \ldots \ldots$ & 11.9 & November - .................. & 10.2 \\
\hline November $15 \ldots \ldots \ldots \ldots \ldots \ldots \ldots$ & 11.75 & & \\
\hline
\end{tabular}

The gage height at the close of the season of 1908 is the lowest ever recorded, being 1.10 feet below the record of the lowest preceding year. This was due, at least in part, to the unusually small rainfall in the drainage area of Devils Lake during 1908. But the drainage 
area has during the past two years been more fully opened to settlement than before, and much new prairie has been broken; it is therefore reasonable to suppose that this will cause permanently a small decrease in the run-off, so that the lake will never entirely regain its former height, unless in a year of abnormally great rainfall.

RED LAKE RIVER AT CROOKSTON, MINN.

This station is located at Crookston, Minn., at the "Sampson's Addition" bridge, one block west of the Great Northern Railway depot. It was established May 19, 1901.

This river is the most important tributary of the Red. The station record has great value in connection with questions of flood damages or navigation on Red River, is necessary to determine the value of the water powers on the main stream and its tributaries, and will show the effect of drainage-ditch construction on the river regimen.

The drainage area above the station is about 5,520 square miles, of which 1,980 square miles lie above the outlet of Red Lake. This is the largest fresh-water lake wholly within the United States, and has an area of 441 square miles. From this portion of the whole drainage area the run-off is therefore very steady. By dredging the outlet, it is possible to use the lake for storage, if it should be profitable.

Red Lake River is a logging stream, and subject to brief abrupt variations when the logs are being sluiced down, but as all the mills are above the station at Crookston, except one at East Grand Forks, which is 25 miles below, the log jams never interfere with the station records.

The station is one-eighth mile below the power house of the Crookston Light, Water and Power Company, through the wheels of which the entire daily flow at low stages passes in about half of the day. At such times the sudden opening or closing of the gates at the mill causes abrupt changes in gage height at the station; but as the gage is read several times daily, it is not supposed that these fluctuations often affect seriously the daily mean.

There has been no change in gage datum nor appreciable change in channel conditions since the establishment of the station, and the open-season records are excellent.

The power-house dam above the station causes the river to remain partially open at the gage through most of the winter in some years, but within a short distance below it freezes smoothly over for about four months. Since 1906, winter discharge measurements have also been made, so that fair estimates of winter flow have been deduced. 
Discharge measurements of Red Lake River at Crookston, Minn., in 1907 and 1908.

\begin{tabular}{|c|c|c|c|c|c|}
\hline Date. & Hydrographer. & Width. & $\begin{array}{l}\text { Area of } \\
\text { section. }\end{array}$ & $\begin{array}{c}\text { Gage. } \\
\text { height. }\end{array}$ & $\begin{array}{c}\text { Dis- } \\
\text { charge. }\end{array}$ \\
\hline & & $\begin{array}{l}\text { Feet. } \\
178\end{array}$ & $S q . f t$. & Feet. & Sec.-ft. \\
\hline $\begin{array}{l}\text { February } 11 a \ldots \\
\text { March } 18 a \ldots\end{array}$ & $\begin{array}{l}\text { E. F. Chandler..... } \\
\ldots \text {. do................ }\end{array}$ & $\begin{array}{l}178 \\
174\end{array}$ & $\begin{array}{l}200 \\
426\end{array}$ & $\begin{array}{l}5.20 \\
5.98\end{array}$ & $\begin{array}{l}458 \\
648\end{array}$ \\
\hline August $3 \ldots . . .$. & Follansbee and Chandler. & 173 & 297 & 4.15 & 612 \\
\hline November $18 b$. & E. F. Chandler........... & 158 & 334 & 4.45 & 621 \\
\hline $\begin{array}{c}1908 . \\
\text { February } 10 \mathrm{a} .\end{array}$ & E. F. Chandler. & 138 & 379 & 5.99 & \\
\hline February $24 a$. & .... do......... & 138 & 325 & 5.52 & 408 \\
\hline June 25 & ..... do & 182 & 911 & 7.50 & 2,640 \\
\hline December $23 a$. & ..... do. & 150 & 331 & 4.54 & 495 \\
\hline
\end{tabular}

a Measurements through ice.

bIce conditions.

Daily gage height, in feet, of Red Lake River at Crookston, Minn., for 1907 and 1908.

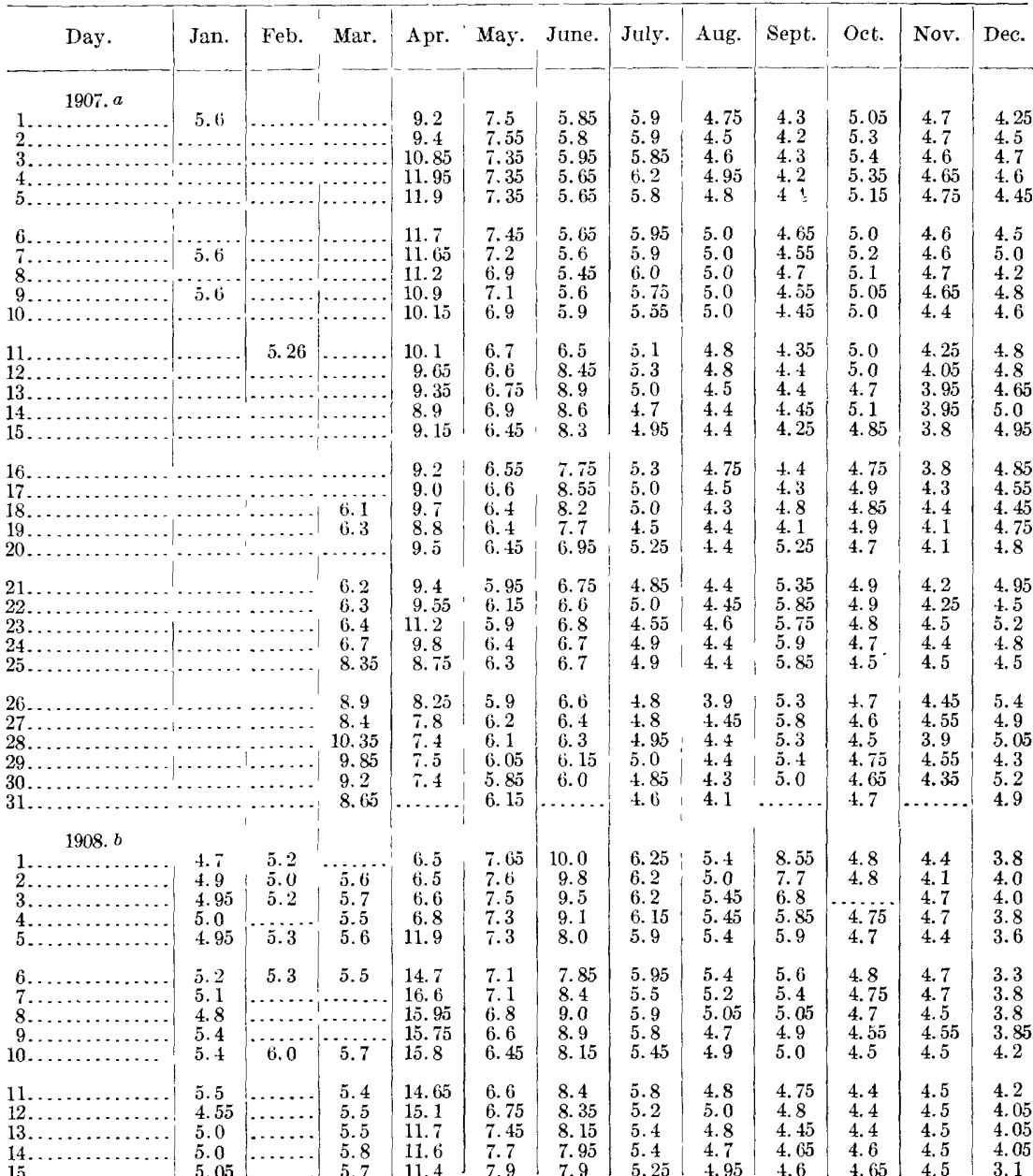

$a$ Ice conditions January 1 to about March 31 and November 15 to December 31, 1907.

$b$ Iee conditions, or partial ice conditions, January 1 to April 5 and November 9 to December 31, 1908. 
Daily gage height, in feet, of Red Lake River at Crookston, Minn., for 1907 and 1908-Continued.

\begin{tabular}{|c|c|c|c|c|c|c|c|c|c|c|c|c|}
\hline Day. & Jan. & Feb. & Mar. & Apr. & May. & June. & July. & Aug. & Sept. & Oct. & Nov. & Dec. \\
\hline 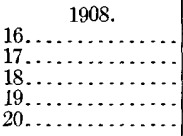 & $\begin{array}{l}5.05 \\
5.05 \\
5.05 \\
5.10 \\
5.15\end{array}$ & 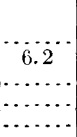 & $\begin{array}{r}5.5 \\
5.7 \\
\cdots .0 \\
6.0 \\
5.8\end{array}$ & $\begin{array}{l}11.1 \\
10.35 \\
9.2 \\
8.65 \\
7.85\end{array}$ & $\begin{array}{l}7.8 \\
8.0 \\
8.1 \\
9.2 \\
9.85\end{array}$ & $\begin{array}{l}7.8 \\
7.8 \\
7.65 \\
7.7 \\
7.3\end{array}$ & $\begin{array}{l}5.25 \\
5.35 \\
5.1 \\
5.1 \\
5.0\end{array}$ & $\begin{array}{l}5.4 \\
4.9 \\
4.9 \\
4.9 \\
5.0\end{array}$ & $\begin{array}{l}4.75 \\
4.6 \\
4.4 \\
4.45 \\
4.45\end{array}$ & $\begin{array}{l}4.1 \\
4.6 \\
4.4 \\
4.65 \\
4.3\end{array}$ & $\begin{array}{l}4.5 \\
4.5 \\
4.5 \\
4.5 \\
4.5\end{array}$ & $\begin{array}{l}4.35 \\
4.2 \\
4.3 \\
4.45 \\
4.3\end{array}$ \\
\hline $\begin{array}{l}21 \ldots \ldots \ldots \\
22 \ldots \ldots \ldots \\
23 \ldots \ldots \ldots \ldots \\
24 \ldots \ldots \ldots \ldots \\
25 \ldots \ldots \ldots \ldots\end{array}$ & $\begin{array}{l}5.15 \\
5.15 \\
5.15 \\
5.15 \\
4.85\end{array}$ & $\begin{array}{l}\cdots \\
5.5 \\
5.52\end{array}$ & $\begin{array}{c}6.0 \\
6.1 \\
\ldots \ldots \\
\cdots \\
6.2\end{array}$ & $\begin{array}{l}7.35 \\
7.0 \\
6.9 \\
6.65 \\
6.9\end{array}$ & $\begin{array}{l}10.2 \\
12.1 \\
12.2 \\
12.1 \\
10.9\end{array}$ & $\begin{array}{l}7.6 \\
7.6 \\
7.5 \\
7.3 \\
7.4\end{array}$ & $\begin{array}{l}5.15 \\
5.2 \\
5.2 \\
5.15 \\
5.1\end{array}$ & $\begin{array}{l}4.85 \\
4.95 \\
4.95 \\
5.0 \\
4.55\end{array}$ & $\begin{array}{l}4.55 \\
4.6 \\
4.55 \\
4.6 \\
4.6\end{array}$ & $\begin{array}{l}4.4 \\
4.9 \\
4.5 \\
4.55 \\
4.0\end{array}$ & $\begin{array}{l}4.5 \\
4.4 \\
4.4 \\
4.4 \\
4.4\end{array}$ & $\begin{array}{l}4.5 \\
4.55 \\
4.55 \\
4.5 \\
4.5\end{array}$ \\
\hline $\begin{array}{l}26 \ldots \ldots \\
27 \ldots \ldots \\
28 \ldots \ldots \\
29 \ldots \ldots \\
30 \ldots \ldots \\
31 \ldots \ldots \\
\end{array}$ & $\begin{array}{l}5.0 \\
5.0 \\
5.1 \\
5.15 \\
5.15 \\
\ldots . .\end{array}$ & $\begin{array}{c}5.55 \\
\ldots \ldots \ldots \\
\ldots \ldots\end{array}$ & $\begin{array}{l}6.3 \\
6.4 \\
6.3 \\
6.4 \\
6.4 \\
6.5\end{array}$ & $\begin{array}{l}7.3 \\
8.0 \\
8.15 \\
7.7 \\
7.4 \\
\ldots . .\end{array}$ & $\begin{array}{l}11.1 \\
11.35 \\
11.15 \\
10.85 \\
10.55 \\
10.4\end{array}$ & $\begin{array}{c}7.2 \\
7.0 \\
6.7 \\
6.5 \\
6.3 \\
\cdots . . .\end{array}$ & $\begin{array}{l}4.8 \\
5.4 \\
4.95 \\
5.2 \\
5.0 \\
5.15\end{array}$ & $\begin{array}{l}5.2 \\
5.0 \\
5.15 \\
5.25 \\
5.2 \\
8.3\end{array}$ & $\begin{array}{l}4.7 \\
4.75 \\
4.9 \\
4.85 \\
4.8 \\
\ldots \ldots\end{array}$ & $\begin{array}{l}4.85 \\
4.5 \\
4.7 \\
4.7 \\
4.65 \\
4.6\end{array}$ & $\begin{array}{r}4.4 \\
4.4 \\
4.4 \\
4.4 \\
4.4 \\
\ldots . .\end{array}$ & $\begin{array}{l}4.55 \\
4.2 \\
4.7 \\
4.7 \\
4.9 \\
4.8\end{array}$ \\
\hline
\end{tabular}

Rating table for Red Lake River at Crookston, Minn., for $190 \%$ and 1908.

\begin{tabular}{|r|r|r|r|r|r|r|r|}
\hline $\begin{array}{c}\text { Gage } \\
\text { height. }\end{array}$ & $\begin{array}{c}\text { Dis- } \\
\text { charge. }\end{array}$ & $\begin{array}{c}\text { Gage } \\
\text { height. }\end{array}$ & $\begin{array}{c}\text { Dis- } \\
\text { charge. }\end{array}$ & $\begin{array}{c}\text { Gage } \\
\text { height. }\end{array}$ & $\begin{array}{c}\text { Dis- } \\
\text { charge. }\end{array}$ & $\begin{array}{c}\text { Gage } \\
\text { height. }\end{array}$ & $\begin{array}{r}\text { Dis- } \\
\text { charge. }\end{array}$ \\
\hline Feet. & Sec.ft. & Feet. & Sec.-ft. & Feet. & Sec.-ft. & Feet. & Sec.-ft. \\
3.80 & 475 & 5.20 & 1,203 & 6.60 & 2,046 & 9.00 & 3,840 \\
3.90 & 515 & 5.30 & 1,260 & 6.70 & 2,112 & 9.20 & 4,000 \\
4.00 & 560 & 5.40 & 1,317 & 6.80 & 2,180 & 9.40 & 4,160 \\
4.10 & 605 & 5.50 & 1,374 & 6.90 & 2,250 & 9.60 & 4,320 \\
4.20 & 655 & 5.60 & 1,432 & 7.00 & 2,320 & 9.80 & 4,480 \\
4.30 & 705 & 5.70 & 1,491 & 7.20 & 2,464 & 10.00 & 4,640 \\
4.40 & 760 & 5.80 & 1,550 & 7.40 & 2,610 & 11.00 & 5,460 \\
4.50 & 815 & 5.90 & 1,610 & 7.60 & 2,758 & 12.00 & 6,300 \\
4.60 & 870 & 6.00 & 1,670 & 7.80 & 2,908 & 13.00 & 7,150 \\
4.70 & 925 & 6.10 & 1,731 & 8.00 & 3,060 & 14.00 & 8,000 \\
4.80 & 980 & 6.20 & 1,792 & 8.20 & 3,216 & 15.00 & 8,900 \\
4.90 & 1,035 & 6.30 & 1,854 & 8.40 & 3,372 & 16.00 & 9,800 \\
5.00 & 1,090 & 6.40 & 1,917 & 8.60 & 3,528 & 17.00 & 10,700 \\
5,10 & 1,146 & 6.50 & 1,981 & 8.80 & 3,684 & & \\
\hline
\end{tabular}

NotE.-The above table is not applicable for ice or obstructed-channel conditions. It is based on discharge measurements made during 1904 to 1908 and is well defined.

Monthly discharge of Red Lake River at Crookston, Minn., for 1907 and 1908.

[Drainage area, 5,520 square miles.]

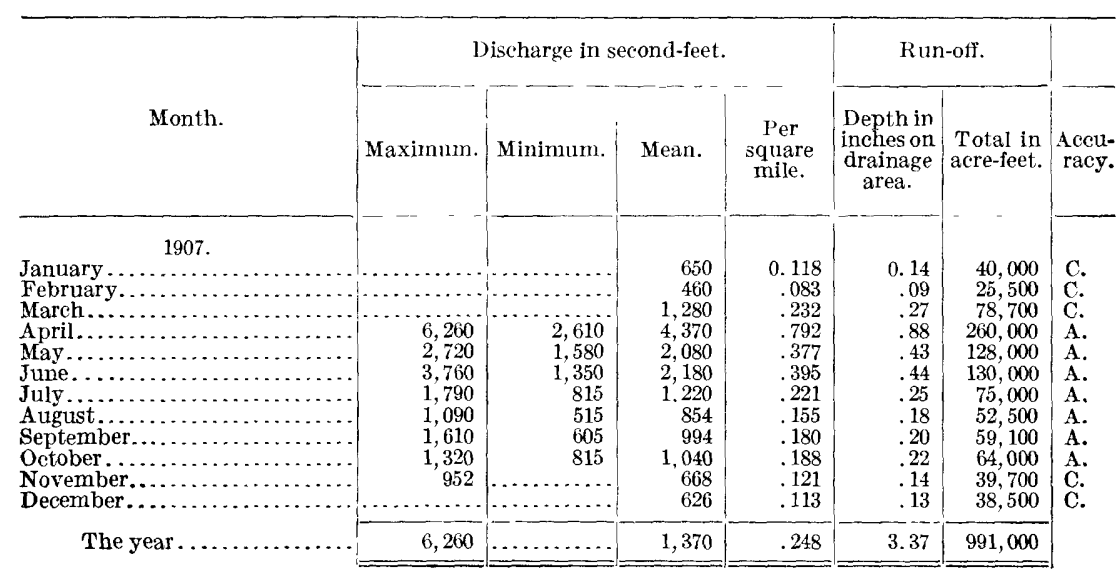


Monthly discharge of Red Lake River at Crookston, Minn., for 1907 and 1908 -Continued.

\begin{tabular}{|c|c|c|c|c|c|c|c|}
\hline \multirow[b]{2}{*}{ Month. } & \multicolumn{4}{|c|}{ Discharge in second-feet. } & \multicolumn{2}{|c|}{ Run-off. } & \multirow[b]{2}{*}{$\begin{array}{l}\text { Accu- } \\
\text { racy. }\end{array}$} \\
\hline & Maximum. & Minimum. & Mean. & $\begin{array}{l}\text { Per } \\
\text { square } \\
\text { mile. }\end{array}$ & $\begin{array}{c}\text { Depth in } \\
\text { inches on } \\
\text { drainage } \\
\text { area. }\end{array}$ & $\begin{array}{l}\text { Total in } \\
\text { acre-feet. }\end{array}$ & \\
\hline 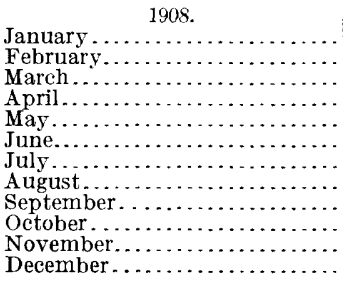 & $\begin{array}{r}\ldots \ldots \\
10,300 \\
6,470 \\
4,640 \\
1,820 \\
3,290 \\
3,490 \\
1,040 \\
\ldots \ldots \ldots \\
\ldots \ldots \ldots \ldots\end{array}$ & \begin{tabular}{|r|}
$\ldots \ldots \ldots$ \\
$\ldots \ldots \ldots$ \\
$\ldots \ldots \ldots$ \\
1,950 \\
1,850 \\
980 \\
842 \\
760 \\
605 \\
$\ldots \ldots \ldots \ldots$ \\
$\ldots \ldots \ldots \ldots$
\end{tabular} & $\begin{array}{r}467 \\
508 \\
620 \\
4,660 \\
3,750 \\
3,050 \\
1,340 \\
1,190 \\
1,180 \\
860 \\
803 \\
437\end{array}$ & $\begin{array}{l}.085 \\
.092 \\
.112 \\
.844 \\
.679 \\
.553 \\
.243 \\
.216 \\
.214 \\
.156 \\
.145 \\
.079\end{array}$ & $\begin{array}{l}.10 \\
.10 \\
.13 \\
.94 \\
.78 \\
.62 \\
.28 \\
.25 \\
.24 \\
.18 \\
.16 \\
.09\end{array}$ & $\begin{array}{r}28,700 \\
29,200 \\
38,100 \\
277,000 \\
231,000 \\
181,000 \\
82,400 \\
73,200 \\
70,200 \\
52,900 \\
47,800 \\
26,900\end{array}$ & $\begin{array}{l}\text { C. } \\
\text { C. } \\
\text { C. } \\
\text { B. } \\
\text { A. } \\
\text { A. } \\
\text { A. } \\
\text { A. } \\
\text { A. } \\
\text { A. } \\
\text { C. } \\
\text { C. }\end{array}$ \\
\hline The year.............. & 10,300 & & 1,570 & .285 & 3.87 & $1,140,000$ & \\
\hline
\end{tabular}

Note.-Ice conditions existed, January 1 to March 25 and November 15 to December 31, 1907; from January 1 to A pril 5 and November 9 to December 31, 1908. Discharge for ice periods has been estimated from occasional measurements and some gage heights and is only fair.

\section{PEMBINA RIVER AT NECHE, N. DAK.}

This station, which was established April 29, 1903, is located at the Great Northern Railway bridge, two-thirds mile north of Neche, N. Dak. Discharge measurements are made from the highway bridge, 20 rods below.

The records of this stream are necessary to determine the value of the many water-power sites on the Pembina, and are valuable in connection with problems of navigation and flood damages on Red River and in drainage investigations.

The total drainage area above this station is about 2,940 square miles, of which 2,020 are in Manitoba, as the stream rises in Manitoba, and flows for about 90 miles close to and nearly parallel with the international boundary, before crossing into North Dakota, 50 miles above its mouth at Pembina.

A loose-rock dam, about 3 feet high, at the railway water-tank intake pipe, one-third mile below the gage, raises the water at the gage from 1 to 2 feet at low stage. As the dam is changed somewhat by the ice each spring, the lower portion of the rating curve requires revision each year. Hence, unless several low-stage discharge measurements are made each season the summaries for the low-water season are merely approximate or fair. The gage datum has not been changed, and the curve for high stage remains constant. 
Discharge measurements of Pembina River at Neche, N. Dak, in $190 \%$ and 1908.

\begin{tabular}{|c|c|c|c|c|c|}
\hline Date. & Hydrographer. & Width. & $\begin{array}{l}\text { Area of } \\
\text { section. }\end{array}$ & $\begin{array}{c}\text { Gage } \\
\text { height. }\end{array}$ & $\begin{array}{l}\text { Dis- } \\
\text { charge. }\end{array}$ \\
\hline 1907. & & Feet. & $S q . f t$ & Feet. & Sec.ft. \\
\hline May $13 \ldots \ldots$. & 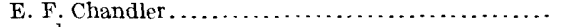 & 86 & 886 & 13.08 & 1,940 \\
\hline July $13 \ldots \ldots . .$. & 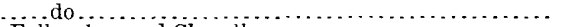 & 65 & 168 & 3.68 & 159 \\
\hline August $2 \ldots \ldots$. & Follansbee and Chandler... & 52 & 113 & 2.72 & 75 \\
\hline September $14 \ldots$ & 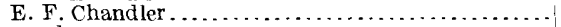 & 65 & 168 & 3.46 & 36 \\
\hline Doa...... & $\ldots \ldots \ldots \ldots \ldots . . . . . .$. & 44 & 43 & 3.46 & 37 \\
\hline $\begin{array}{r}1908 . \\
\text { January } 27 .\end{array}$ & E. F. Chandler. & 39 & 11.7 & 2.13 & 3.8 \\
\hline A pril $3 b \ldots$ & .... do.......... & $\ldots \ldots$ & & 3.40 & 3.0 \\
\hline June 24 .. & $\ldots .$. do $\ldots . . . .$. & 66.5 & 172 & 4. 13 & 191 \\
\hline July $24 a$. & .....do....... & 55 & 54 & 3.18 & 53 \\
\hline Do.. & ....do....... & 59.5 & 110 & 3.18 & 51 \\
\hline
\end{tabular}

$a$ Wading measurements.

$b$ Ice conditions, and discharge estimated.

Daily gage height, in feet, of Pembina River at Neche, N. Dak., for 1907 and 1908.

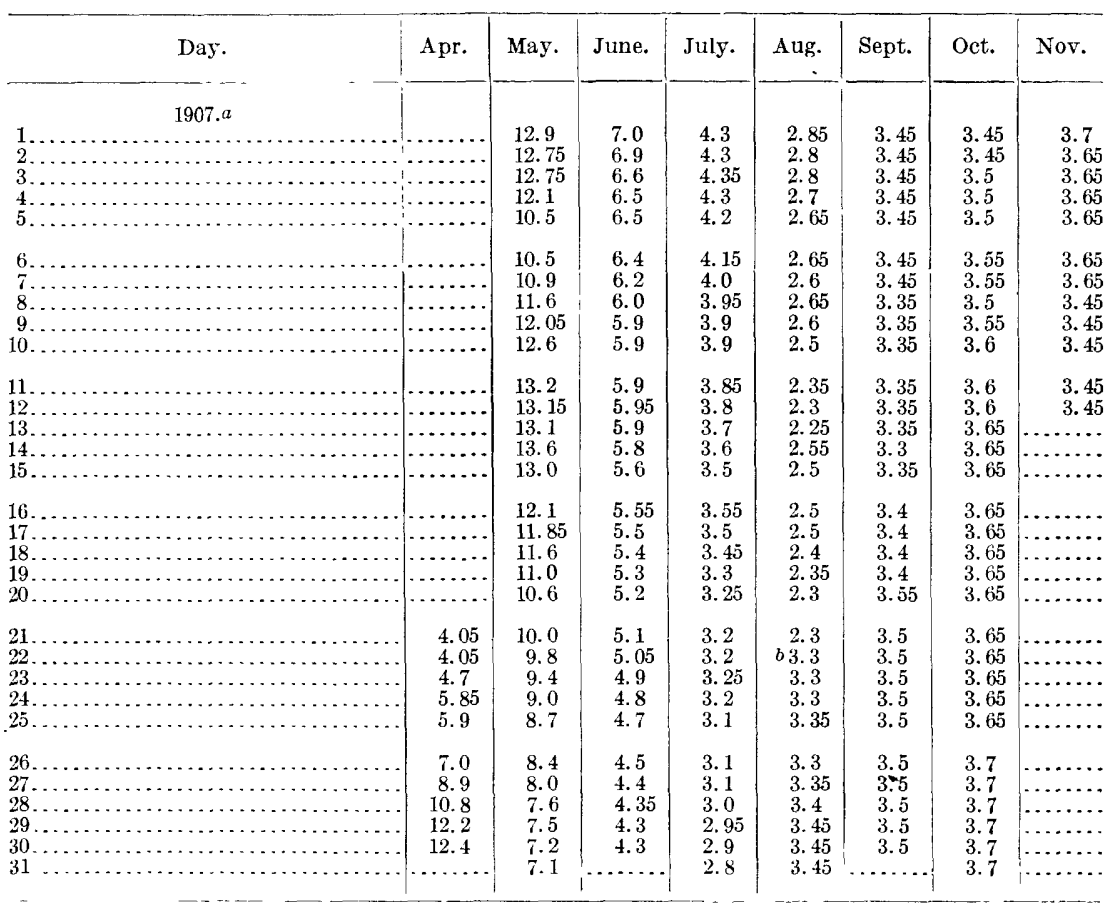

a Ice broke up April 27, 1907; river frozen November 8 to December 31, 1907. $b$ Dam rebuilt and raised, August $22,1907$. 
Daily gage height, in feet, of Pembina River at Neche, N. Dak., for 190\% and 1908-Con.

\begin{tabular}{|c|c|c|c|c|c|c|c|c|c|c|c|c|c|c|c|}
\hline Day. & Apr. & May. & June. & July. & A11g. & Sept. & $O C+$ & Day. & Apr. & May. & June. & July. & Aug. & Sept. & Oct. \\
\hline $1908 . a$ & & & & & & & & $1908, a$ & & & & & & & \\
\hline & & 4.85 & 5.6 & 3.8 & 3.0 & 3.3 & 3.2 & 16. & 4.7 & 5.85 & 4.0 & 3.45 & 3.2 & 3.25 & \\
\hline 2. & & 4.85 & 5.5 & 3.8 & 3.0 & 3.3 & 3.2 & 17 & 4. 7 & 5.85 & 3.95 & 3.4 & 3.25 & 3.25 & 4.4 \\
\hline 3 & 3.4 & 4.8 & 5.4 & 3.8 & 3.05 & 3.3 & 3.1 & 18 & 4.7 & 5.8 & 3.95 & 3.35 & 3.2 & 3.25 & 4.4 \\
\hline & $\cdots$ & 4.8 & 5.25 & 3. 75 & 3.1 & 3.25 & 3.1 & & 4. 7 & 5.8 & 3.95 & 3.3 & 3.2 & 3.25 & 4.4 \\
\hline 5 & 3.9 & 4.8 & 5.0 & 3.75 & 3.1 & 3.25 & 3.15 & 20 & 4.7 & 5.8 & 3.9 & 3.3 & 3.2 & 3.25 & 4.4 \\
\hline 6. & 3.9 & 4.75 & 4.9 & 3.75 & 3.1 & 3.25 & 3.1 & 21 & 4.65 & 5. 75 & 3.9 & 3.3 & 3.25 & 3.25 & 4.45 \\
\hline & 5.9 & 4.85 & 4.8 & 3.75 & 3.05 & 3.2 & 3.2 & 22 & 4.65 & 5.75 & 3.9 & 3.3 & 3.2 & 3.25 & 4.45 \\
\hline & 6.95 & 4.95 & 4.65 & 3. 7 & 3.0 & 3.2 & 3.15 & 23. & 4.6 & 5.7 & 3.9 & 3.3 & 3.15 & 3.25 & 4.4 \\
\hline 9 & 7.0 & 5.5 & 4.45 & 3.7 & 3.0 & 3.2 & 3.1 & 24 & 4.9 & 5.7 & 3.9 & 3.2 & 3.15 & 3.25 & 4. 4 \\
\hline 10 & 7.7 & 5.6 & 4.3 & 3.7 & 3.0 & 3.2 & 3.1 & 25 & 5.2 & 5.7 & 3.85 & 3.2 & 3.15 & 3.4 & 4.45 \\
\hline 11. & 7.0 & 6.1 & 4.15 & 3.65 & 3.3 & 3.2 & $b 4.1$ & 26 & 5.3 & 5.75 & 3.85 & 3.1 & 3.15 & 3.4 & 4.45 \\
\hline 12. & 6.5 & 6.0 & 4.05 & 3.65 & 3.3 & 3.2 & 4.1 & 27 & 5.1 & 5.8 & 3.85 & 3.1 & 3.2 & 3.3 & 4.45 \\
\hline 13. & 6.0 & 5.9 & 4.0 & 3.6 & 3.3 & 3.2 & 4.1 & 28. & 5.0 & 5.9 & 3.8 & 3.1 & 3.2 & 3.3 & 4.45 \\
\hline 14 & 5.7 & 5.85 & 4.0 & 3.55 & 3.3 & 3.2 & 4.1 & 29. & 4.9 & 5.75 & 3.8 & 3.05 & 3.25 & 3.3 & 4.4 \\
\hline 15 & 5.5 & 5.85 & 4.0 & 3.5 & 3.25 & 3.25 & 4. 1 & 30. & 4.85 & 5.7 & 3.8 & 3.05 & 3.3 & 3.2 & 4.4 \\
\hline & & & & & & & & & $\cdots$ & & $\cdots$ & 3.0 & 3.3 & $\cdots$ & 4.4 \\
\hline
\end{tabular}

$a$ Ice conditions $\mathrm{J}_{\text {anuary }} 1$ to April 5 and November 8 to December 31, 1908.

$b$ Dam raised October $11,1908$.

Rating tables for Pernbina River at Neche, N. Dak.

APRIL 20 TO AUGUST 21, 1907.

\begin{tabular}{|r|r||r|r||r|r||r|r|}
\hline $\begin{array}{c}\text { Gage } \\
\text { height. }\end{array}$ & $\begin{array}{c}\text { Dis- } \\
\text { charge. }\end{array}$ & $\begin{array}{c}\text { Gage } \\
\text { height. }\end{array}$ & $\begin{array}{c}\text { Dis- } \\
\text { charge. }\end{array}$ & $\begin{array}{c}\text { Gage } \\
\text { height. }\end{array}$ & $\begin{array}{c}\text { Dis- } \\
\text { charge. }\end{array}$ & $\begin{array}{c}\text { Gage } \\
\text { height. }\end{array}$ & $\begin{array}{c}\text { Dis- } \\
\text { charge. }\end{array}$ \\
\hline Feet. & Sec. $-f t$. & Feet. & Sec. $f t$. & Feet. & Sec. $f t$. & Feet. & Sec.-ft. \\
2.30 & 49 & 3.30 & 115 & 4.30 & 263 & 5.30 & 455 \\
2.40 & 54 & 3.40 & 125 & 4.40 & 282 & 5.40 & 475 \\
2.50 & 59 & 3.50 & 136 & 4.50 & 301 & 5.50 & 495 \\
2.60 & 64 & 3.60 & 148 & 4.60 & 320 & 5.60 & 515 \\
2.70 & 70 & 3.70 & 161 & 4.70 & 339 & 5.70 & 535 \\
2.80 & 76 & 3.80 & 176 & 4.80 & 358 & 5.80 & 555 \\
2.90 & 83 & 3.90 & 192 & 4.90 & 377 & 5.90 & 575 \\
3.00 & 90 & 4.00 & 209 & 5.00 & 396 & 6.00 & 595 \\
3.10 & 98 & 4.10 & 227 & 5.10 & 415 & & \\
3.20 & 106 & 4.20 & 245 & 5.20 & 435 & & \\
\hline
\end{tabular}

Note. - The above table is not applicable for ice or obstructed-channel conditions. It is based on three discharge measurements made during the above period and form of previous curves, and is well defined. Above gage height 6 feet the rating curve is a tangent, the difference being 21 per tenth.

AUGUST 22 TO DECEMBER 31, 1907.

\begin{tabular}{|c|r||c|c|c|c|c|c|}
\hline $\begin{array}{c}\text { Gage } \\
\text { height. }\end{array}$ & $\begin{array}{c}\text { Dis- } \\
\text { charge. }\end{array}$ & $\begin{array}{c}\text { Gage } \\
\text { height. }\end{array}$ & $\begin{array}{c}\text { Dis- } \\
\text { charge. }\end{array}$ & $\begin{array}{c}\text { Gage } \\
\text { height. }\end{array}$ & $\begin{array}{c}\text { Dis- } \\
\text { charge. }\end{array}$ & $\begin{array}{c}\text { Gage } \\
\text { height. }\end{array}$ & $\begin{array}{c}\text { Dis- } \\
\text { charge. }\end{array}$ \\
\hline Fect. & Sec.-ft. & Feet. & Sec.-ft. & Feet. & Sec. $f t$. & Feet. & Sec. ft. \\
3.30 & 23 & 3.50 & 41 & 3.60 & 53 & 3.70 & 60 \\
3.40 & 31 & & & & & & \\
\hline
\end{tabular}

Note.-The above table is not applicable for ice or obstructed-channel conditions. It is based on two discharge measurenents made during above period and form of previous curves, and is not well defined.

JANUARY 1 TO OCTOBER 10, 1908.

\begin{tabular}{|r|r|r|r|r|r|r|r|}
\hline $\begin{array}{c}\text { Gage } \\
\text { height. }\end{array}$ & $\begin{array}{c}\text { Dis- } \\
\text { charge. }\end{array}$ & $\begin{array}{c}\text { Gage } \\
\text { height. }\end{array}$ & $\begin{array}{c}\text { Dis- } \\
\text { charge. }\end{array}$ & $\begin{array}{c}\text { Gage } \\
\text { height. }\end{array}$ & $\begin{array}{c}\text { Dis- } \\
\text { charge. }\end{array}$ & $\begin{array}{c}\text { Gage } \\
\text { height. }\end{array}$ & $\begin{array}{c}\text { Dis- } \\
\text { charge. }\end{array}$ \\
\hline Feet. & Sec.-ft. & Feet. & Sec.-ft. & Feet. & Sec.ft. & Feet. & Sec. ft. \\
3.00 & 36 & 3.60 & 105 & 4.20 & 204 & 4.80 & 320 \\
3.10 & 45 & 3.70 & 120 & 4.30 & 222 & 4.90 & 340 \\
3.20 & 55 & 3.80 & 136 & 4.40 & 241 & 5.00 & 360 \\
3.30 & 66 & 3.90 & 152 & 4.50 & 260 & & \\
3.40 & 78 & 4.00 & 169 & 4.60 & 280 & & \\
3.50 & 91 & 4.10 & 186 & 4.70 & 300 & & \\
\hline
\end{tabular}

Note.-The above table is not applicable for ice or obstructed-channel conditions. It is based on four discharge measurements made during 1908 and form of previous curve, and is well defined. Above gage height 5 feet the rating curve is a tangent, the difference being 21 per tenth. 
Monthly discharge of Pembina River at Neche, N. Dak., for 1907 and 1908.

[Diainage area, 2,940 square miles.]

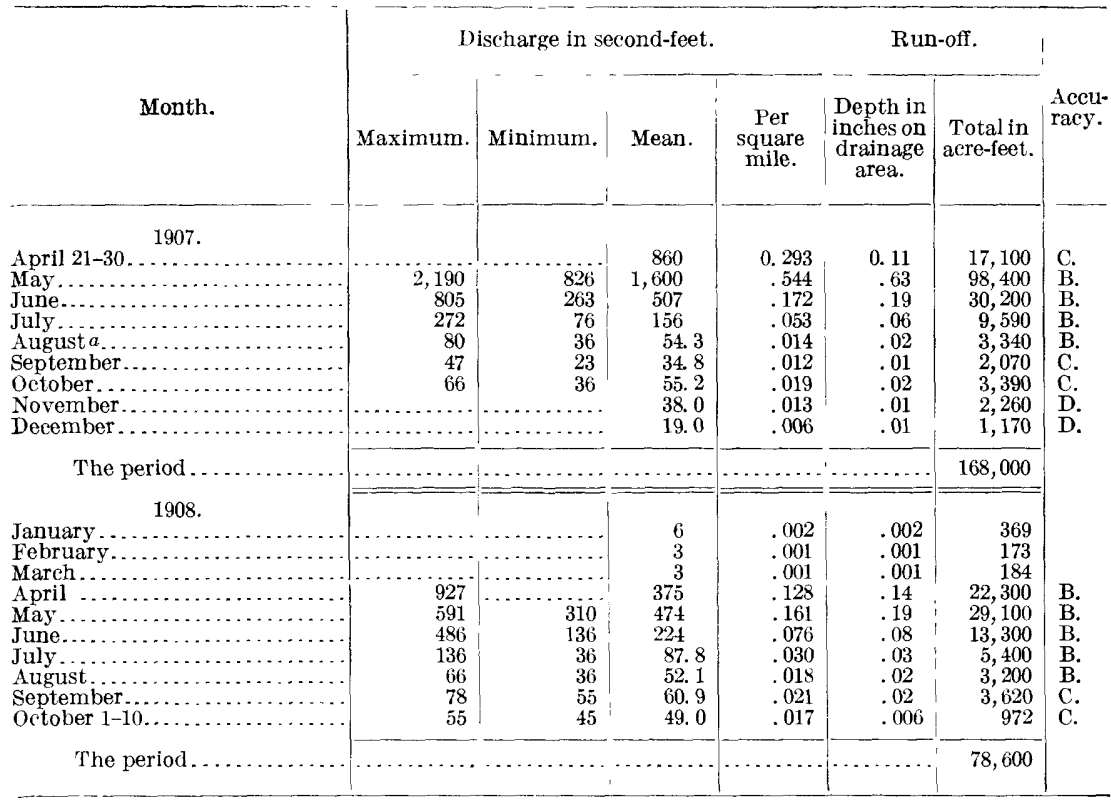

$a$ Discharge corrected August 22 to 28, 1907, for effect of construction work on dam.

Note.-Diseharge estimated for April 21-30, 1907, when ice was breaking up. Also estimated for period November 1, 1907, to April 4, 1908, being based on one measurement and an estimated measurement. The discharge January 1 to April 4, 1908, is only a rough approximation and is given merely to indicate in a general way the relatively low flow which probably oceurred during this period.

\section{MOUSE RIVER AT MINOT, N. DAK.}

The Mouse (or Souris) River rises in the southeastern part of the province of Assiniboia, Canada, and flows southeastward 150 miles to the northern boundary of North Dakota; thence it continues in a southeasterly direction for 80 miles to the southwestern part of McHenry County, thence northeast 40 miles, thence it completes a loop by swinging to the north and northwest, and in 50 miles reaches the Canadian boundary again. Thence it flows north and east 120 miles through the province of Manitoba to Assiniboine River, which discharges into Red River 120 miles farther east, at Winnipeg.

The drainage area above the point where the river enters the Cnited States is about 7,200 square miles, nine-tenths of this area being in Assiniboia and the remainder a narrow strip along the northern edge of North Dakota. Above the point where the river leaves the United States the total drainage area is about 12,000 square miles.

The Mouse has only three important tributaries in North DakotaDes Lacs River, draining about 700 square miles, and Cut Bank and 
Willow creeks, draining each about 1,100 square miles. All these streams flow from a rolling prairie whose surface was left uneven by the ice of the glacial epoch and whose drainage is imperfectly developed. Hence in ordinary years the run-off from only a small portion of the drainage area, perhaps one-fourth, reaches the streams, but the water stands in scattered pools and lakelets that dry away through the season. In unusually wet or stormy years, these pools and sloughs overflow, causing abnormal increases in the flow of the river.

The whole area is deeply covered with glacial drift, except a portion of the "Mouse River loop," which is covered with silt and is more level, having been in the glacial epoch the bottom of Lake Souris, an arm of Lake Agassiz, which filled the Red River valley at that time.

The elevation of this drainage basin is 1,450 feet above sea level at the lowest point in North Dakota and about 2,000 feet at its western margin in North Dakota.

In the upper portion of its course the river occupies a valley a hundred feet deep and a mile wide; after turning north around the loop, it runs through a prairie scarcely above the water level. The whole stretch in North Dakota is very sluggish on account of its small fall, and in the last 40 miles before the river reenters Canada its total fall is only 8 feet.

The area is without forests or trees except small scattered clumps or groves on the steep hillsides and fringes along the streams. The mean annual rainfall is from 13 to 17 inches, half of which falls in the three months of May, June, and July.

During the winter the streams are closed for at least four months, and the flow beneath the ice is very small. Thaws sufficient to cause any considerable rise or flood in winter are unknown.

The stations in the Mouse River basin were established to determine the possibility of irrigation, and the records have shown that (except in years so wet that the irrigation would be of little value) the flow of the streams is too small to justify as expensive construction as would be necessary for extensive irrigation works in a country of such small slope. The station records are now found to be essential for investigating the methods of reclamation by drainage in the Mouse River loop, and for flood prevention.

The tributaries present some storage possibilities, as, for example, at Des Lacs Lakes on Des Lacs River, but losses by evaporation would be so great that this storage would probably be useless except for flood prevention.

The gaging station, which is located north of the Great Northern Railway roundhouse, at Minot, N. Dak., was established May 5, 1903.

Des Lacs River enters 7 miles above the station. 
The gage datum has not been changed, and channel conditions remain nearly constant, but the gage height at low stage is controlled by a 3-foot dam at the Soo Railway water tank, a mile below the gage, which at extreme low water raises the water at the gage about 2 feet. The dam was rebuilt and changed during the summer of 1904, but has since been unchanged. It is a tight plank dam with level crest, to which weir formulas have been found to apply satisfactorily, so that a very good rating curve for all ordinary stages has been developed, and the monthly discharge is accurate.

Discharge measurements of Mouse River at Minot, N. Dak., in $190^{\text {'y }}$ and 1908.

\begin{tabular}{|c|c|c|c|c|c|}
\hline Date. & Hydrographer. & Width. & $\begin{array}{l}\text { Area of } \\
\text { section. }\end{array}$ & $\begin{array}{c}\text { Gage } \\
\text { height. }\end{array}$ & $\begin{array}{c}\text { Dis- } \\
\text { charge. }\end{array}$ \\
\hline $\begin{array}{c}1907 . \\
\text { May } 12 \ldots\end{array}$ & F. F. Chandler... & $\begin{array}{l}\text { Feet. } \\
109\end{array}$ & $\underset{89 . f t}{850}$ & $\begin{array}{l}\text { Feet. } \\
11.23\end{array}$ & $\begin{array}{l}\text { Sec.-ft. } \\
1,360\end{array}$ \\
\hline May $27 . .$. & .... do............ & 174 & 1,490 & 15.88 & 2,170 \\
\hline July $1 \ldots .$. & ....do........... & 86 & 386 & 6.61 & 672 \\
\hline August $6 \ldots .$. & ....do.......... & 76 & 214 & 4. 50 & 149 \\
\hline December $21 a$. & ....do........... & 42 & 50 & 3.80 & 9.6 \\
\hline $\begin{array}{c}1908 . \\
\text { May } 30 \ldots \text {. }\end{array}$ & E. F. Chandler. & & 226 & 4.67 & \\
\hline Do $b$ & .... do............ & 57.5 & $\begin{array}{r}220 \\
89\end{array}$ & $\begin{array}{l}4.07 \\
4.67\end{array}$ & $\begin{array}{l}112 \\
156\end{array}$ \\
\hline October $11 b$ & |... do .............. & 48 & 40 & 3.82 & 13.1 \\
\hline Dob... & 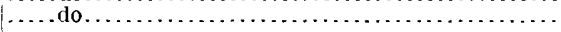 & 26 & 11. 4 & 3. 82 & 11.7 \\
\hline
\end{tabular}

a River frozen at point of measurement, but clear at gage.

$b$ Wading measurement.

Daily gage height, in feet, of Mouse River at Minot, N. Dak., for $190 \%$ and 1908.

\begin{tabular}{|c|c|c|c|c|c|c|c|c|c|c|c|c|c|}
\hline Day. & Apr. & May. & June. & July. & Aug. & Sept. & Day. & Apr. & May. & June. & July. & Aug. & Sept. \\
\hline 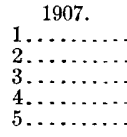 & $\begin{array}{l}4.0 \\
4.0 \\
4.0 \\
4.0 \\
4.0\end{array}$ & $\begin{array}{l}6.8 \\
7.0 \\
7.2 \\
7.4 \\
7.8\end{array}$ & $\begin{array}{l}15.7 \\
15.3 \\
15.0 \\
14.7 \\
14.0\end{array}$ & $\begin{array}{l}6.8 \\
7.5 \\
7.9 \\
7.7 \\
7.4\end{array}$ & $\begin{array}{l}4.9 \\
4.8 \\
4.8 \\
4.7 \\
4.5\end{array}$ & $\begin{array}{l}4.1 \\
4.1 \\
4.1 \\
4.1 \\
4.1\end{array}$ & $\begin{array}{c}1907 . \\
16 \ldots \ldots \\
17 \ldots \ldots \\
18 \ldots \ldots \\
19 \ldots \ldots \\
20 \ldots \ldots\end{array}$ & $\begin{array}{l}4.5 \\
4.6 \\
4.6 \\
4.6 \\
4.8\end{array}$ & $\begin{array}{l}12.8 \\
13.2 \\
13.6 \\
13.8 \\
14.1\end{array}$ & $\begin{array}{l}5.7 \\
5.7 \\
5.6 \\
5.6 \\
5.5\end{array}$ & $\begin{array}{l}5.4 \\
5.3 \\
5.3 \\
5.2 \\
5.2\end{array}$ & $\begin{array}{l}4.35 \\
4.35 \\
4.35 \\
4.3 \\
4.3\end{array}$ & $\begin{array}{l}4.0 \\
4.0 \\
4.0 \\
4.0 \\
4.0\end{array}$ \\
\hline $\begin{array}{r}6 \ldots \ldots \ldots \\
7 \ldots \ldots \\
8 \ldots \ldots \\
9 \ldots \ldots \\
10 \ldots \ldots\end{array}$ & $\begin{array}{l}4.0 \\
4.0 \\
4.1 \\
4.1 \\
4.1\end{array}$ & $\begin{array}{r}8.0 \\
8.4 \\
9.0 \\
9.6 \\
10.0\end{array}$ & $\begin{array}{r}13.0 \\
12.0 \\
11.0 \\
10.0 \\
8.7\end{array}$ & $\begin{array}{l}6.0 \\
5.9 \\
6.0 \\
6.7 \\
6.7\end{array}$ & \begin{tabular}{|l|}
4.5 \\
4.5 \\
4.45 \\
4.45 \\
4.4
\end{tabular} & $\begin{array}{l}4.1 \\
4.1 \\
4.05 \\
4.05 \\
4.05\end{array}$ & $\begin{array}{l}21 . \\
22 . \\
23 . \\
24 . \\
25 .\end{array}$ & $\begin{array}{l}4.8 \\
4.8 \\
5.0 \\
5.2 \\
5.4\end{array}$ & $\begin{array}{l}14.5 \\
14.9 \\
15.0 \\
15.2 \\
15.5\end{array}$ & $\begin{array}{l}5.4 \\
5.3 \\
5.2 \\
5.2 \\
5.1\end{array}$ & $\begin{array}{l}5.2 \\
5.6 \\
5.9 \\
5.9 \\
5.7\end{array}$ & $\begin{array}{l}4.25 \\
4.25 \\
4.2 \\
4.2 \\
4.2\end{array}$ & $\begin{array}{l}4.0 \\
3.95 \\
3.95 \\
3.95 \\
3.9\end{array}$ \\
\hline $\begin{array}{l}11 \ldots \ldots \\
12 \ldots \ldots \\
13 \ldots \ldots \\
14 \ldots \ldots \\
15 \ldots\end{array}$ & $\begin{array}{l}4.2 \\
4.2 \\
4.3 \\
4.4 \\
4.4\end{array}$ & $\begin{array}{l}10.6 \\
11.4 \\
11.8 \\
12.2 \\
12.5\end{array}$ & $\begin{array}{l}6.5 \\
6.0 \\
5.8 \\
5.8 \\
5.7\end{array}$ & $\begin{array}{l}6.2 \\
5.7 \\
5.5 \\
5.5 \\
5.4\end{array}$ & $\begin{array}{l}4.4 \\
4.4 \\
4.4 \\
4.35 \\
4.35\end{array}$ & $\begin{array}{l}4.0 \\
4.0 \\
4.0 \\
4.0 \\
4.0\end{array}$ & $\begin{array}{l}26 \ldots \\
27 \ldots \\
28 \ldots \\
29 \ldots \\
30 \ldots \\
31 \ldots\end{array}$ & $\begin{array}{l}5.6 \\
5.8 \\
6.0 \\
\text { 6. } 2 \\
6.4\end{array}$ & $\begin{array}{l}15.7 \\
15.9 \\
16.0 \\
16.0 \\
16.0 \\
15.8\end{array}$ & $\begin{array}{l}5.1 \\
5.6 \\
6.0 \\
6.7 \\
6.8\end{array}$ & $\begin{array}{l}5.5 \\
5.2 \\
5.2 \\
5.2 \\
5.1 \\
5.0\end{array}$ & $\begin{array}{l}4.15 \\
4.15 \\
4.1 \\
4.1 \\
4.1 \\
4.1\end{array}$ & $\begin{array}{l}3.9 \\
3.9 \\
3.9 \\
3.9 \\
3.9\end{array}$ \\
\hline
\end{tabular}


Daily gage height, in feet, of Mouse River at Minot, N. Dak., for 1907 and 1908-Con.

\begin{tabular}{|c|c|c|c|c|c|c|c|c|}
\hline Day. & Apr. & May. & June. & July. & Aug. & Sept. & Oct. & Nov. \\
\hline 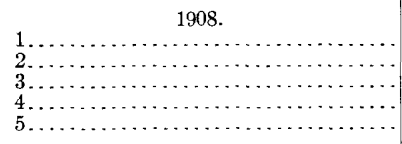 & $\begin{array}{l}4.7 \\
4.8 \\
4.8 \\
5.0 \\
5.0\end{array}$ & $\begin{array}{l}4.65 \\
4.55 \\
4.5 \\
4.5 \\
4.45\end{array}$ & $\begin{array}{l}4.6 \\
\text { 4. } 65 \\
\text { 4. } 65 \\
4.7 \\
4.75\end{array}$ & $\begin{array}{l}4.7 \\
4.6 \\
4.6 \\
4.6 \\
4.6\end{array}$ & $\begin{array}{l}4.45 \\
4.45 \\
4.4 \\
4.4 \\
4.35\end{array}$ & $\begin{array}{l}4.3 \\
4.25 \\
4.25 \\
4.25 \\
4.25\end{array}$ & $\begin{array}{l}3.95 \\
3.95 \\
3.95 \\
3.95 \\
3.95\end{array}$ & $\begin{array}{l}3.95 \\
3.95 \\
4.0 \\
4.0 \\
4.0\end{array}$ \\
\hline $\begin{array}{r}6 \ldots \ldots \ldots \\
7 \ldots \ldots \\
8 \ldots \ldots \ldots \\
9 \ldots \ldots \ldots \\
10 \ldots \ldots\end{array}$ & $\begin{array}{l}5.0 \\
5.1 \\
5.5 \\
6.0 \\
5.5\end{array}$ & $\begin{array}{l}4.45 \\
4.4 \\
4.4 \\
4.4 \\
4.45\end{array}$ & $\begin{array}{l}4.8 \\
4.85 \\
4.9 \\
4.95 \\
4.95\end{array}$ & $\begin{array}{l}4.6 \\
4.55 \\
4.55 \\
4.4 \\
4.4\end{array}$ & $\begin{array}{l}4.35 \\
4.35 \\
4.35 \\
4.35 \\
4.35\end{array}$ & $\begin{array}{l}4.25 \\
4.25 \\
4.25 \\
4.2 \\
4.2\end{array}$ & $\begin{array}{l}3.95 \\
3.9 \\
3.9 \\
3.9 \\
3.9\end{array}$ & $\begin{array}{l}4.0 \\
4.0 \\
4.0 \\
4.0 \\
4.0\end{array}$ \\
\hline $\begin{array}{l}11 \ldots \ldots \ldots \\
12 \ldots \ldots \\
13 \ldots \ldots \ldots \\
14 \ldots \ldots \\
15 \ldots \ldots\end{array}$ & $\begin{array}{l}5.0 \\
5.5 \\
6.5 \\
6.0 \\
5.85\end{array}$ & $\begin{array}{l}4.45 \\
4.5 \\
4.5 \\
4.5 \\
4.45\end{array}$ & $\begin{array}{l}4.95 \\
4.9 \\
4.9 \\
4.85 \\
4.9\end{array}$ & $\begin{array}{l}4.45 \\
4.5 \\
4.5 \\
4.5 \\
4.5\end{array}$ & $\begin{array}{l}4.35 \\
4.35 \\
4.3 \\
4.25 \\
4.25\end{array}$ & $\begin{array}{l}4.2 \\
4.2 \\
4.2 \\
4.2 \\
4.2\end{array}$ & $\begin{array}{l}3.9 \\
3.9 \\
3.9 \\
3.85 \\
3.85\end{array}$ & $\begin{array}{l}\text { 3. } 95 \\
3.95 \\
3.95 \\
3.95 \\
3.95\end{array}$ \\
\hline $\begin{array}{l}16 \ldots \ldots \\
17, \ldots \ldots \\
18 \ldots \ldots \\
19 \ldots \ldots \\
20 \ldots \ldots \\
\end{array}$ & $\begin{array}{l}5.75 \\
5.65 \\
5.0 \\
5.4 \\
5.4\end{array}$ & $\begin{array}{l}4.5 \\
4.5 \\
4.45 \\
4.5 \\
4.55\end{array}$ & $\begin{array}{l}4.9 \\
4.9 \\
5.6 \\
5.6 \\
5.6\end{array}$ & $\begin{array}{l}4.45 \\
4.5 \\
4.55 \\
4.55 \\
4.45\end{array}$ & $\begin{array}{l}4.25 \\
4.3 \\
4.3 \\
4.35 \\
4.3\end{array}$ & $\begin{array}{l}4.2 \\
4.1 \\
4.1 \\
4.1 \\
4.1\end{array}$ & $\begin{array}{l}3.85 \\
3.85 \\
3.85 \\
3.85 \\
3.85\end{array}$ & $\begin{array}{l}3.95 \\
3.95 \\
4.0 \\
4.0 \\
4.0\end{array}$ \\
\hline $\begin{array}{l}21 \ldots \ldots \ldots \ldots \\
22 \ldots \ldots \ldots \\
23 \ldots \ldots \\
24 \ldots \ldots \\
25 \ldots \ldots\end{array}$ & $\begin{array}{l}5.35 \\
5.25 \\
5.15 \\
5.0 \\
4.95\end{array}$ & $\begin{array}{l}4.55 \\
4.6 \\
4.55 \\
4.6 \\
4.6\end{array}$ & $\begin{array}{l}5.5 \\
5.3 \\
5.3 \\
5.1 \\
5.0\end{array}$ & $\begin{array}{l}4.45 \\
4.4 \\
4.35 \\
4.35 \\
4.35\end{array}$ & $\begin{array}{l}4.3 \\
4.3 \\
4.3 \\
4.3 \\
4.3\end{array}$ & $\begin{array}{l}4.1 \\
4.1 \\
3.95 \\
3.95 \\
4.1\end{array}$ & \begin{tabular}{l|}
3.9 \\
3.9 \\
3.95 \\
3.95 \\
3.95
\end{tabular} & $\begin{array}{l}4.0 \\
4.0 \\
3.95 \\
3.95 \\
3.95\end{array}$ \\
\hline $\begin{array}{l}26 \ldots \\
27 \ldots \\
27 \ldots \\
29 \ldots \\
30 \ldots \\
31 \ldots\end{array}$ & $\begin{array}{l}4.95 \\
4.95 \\
4.85 \\
4.75 \\
4.7\end{array}$ & $\begin{array}{l}\text { 4. } 6 \\
4.65 \\
4.65 \\
4.6 \\
4.6 \\
4.65\end{array}$ & $\begin{array}{l}4.9 \\
4.8 \\
4.75 \\
4.75 \\
4.7\end{array}$ & $\begin{array}{l}4.35 \\
4.35 \\
4.4 \\
4.4 \\
4.35 \\
4.4\end{array}$ & $\begin{array}{l}4.25 \\
4.25 \\
4.3 \\
4.3 \\
4.3 \\
4.35\end{array}$ & $\begin{array}{l}4.1 \\
4.1 \\
4.1 \\
4.1 \\
4.1\end{array}$ & $\begin{array}{l}3.95 \\
4.0 \\
4.0 \\
4.0 \\
4.0 \\
4.0\end{array}$ & $\begin{array}{l}3.95 \\
3.95 \\
3.95 \\
\cdots \cdots \\
\cdots \cdots\end{array}$ \\
\hline
\end{tabular}

Note - The gage heights were affected by ice conditions during 1907-8 about as follows: January 1 to March 31, and during part of November and all of December, 1907; January 1 to March 31, November 14 to 18 and November 29 to December 31,1908 .

Rating table for Mouse River at Minot, N. Dak., for $190 \%$ and 1908.

\begin{tabular}{|c|c|c|r|r|r|r|r|}
\hline $\begin{array}{c}\text { Gage } \\
\text { height. }\end{array}$ & $\begin{array}{c}\text { Dis- } \\
\text { charge. }\end{array}$ & $\begin{array}{c}\text { Gage } \\
\text { height. }\end{array}$ & $\begin{array}{c}\text { Dis- } \\
\text { charge. }\end{array}$ & $\begin{array}{c}\text { Gage } \\
\text { height. }\end{array}$ & $\begin{array}{c}\text { Dis- } \\
\text { charge. }\end{array}$ & $\begin{array}{c}\text { Gage } \\
\text { height. }\end{array}$ & $\begin{array}{c}\text { Dis- } \\
\text { charge. }\end{array}$ \\
\hline Feet. & Sec.-ft. & Feet. & Sec.-ft. & Fect. & Sec.-ft. & Feet. & Sec.-ft. \\
3.80 & 9.2 & 5.20 & 294 & 6.60 & 666 & 9.00 & 1,038 \\
3.90 & 20 & 5.30 & 321 & 6.70 & 687 & 9.20 & 1,064 \\
4.00 & 35 & 5.40 & 349 & 6.80 & 707 & 9.40 & 1,088 \\
4.10 & 52 & 5.50 & 378 & 6.90 & 726 & 9.60 & 1,112 \\
4.20 & 70 & 5.60 & 407 & 7.00 & 744 & 9.80 & 1,136 \\
4.30 & 89 & 5.70 & 436 & 7.20 & 778 & 10.00 & 1,160 \\
4.40 & 109 & 5.80 & 464 & 7.40 & 810 & 11.00 & 1,280 \\
4.50 & 130 & 5.90 & 492 & 7.60 & 841 & 12.00 & 1,400 \\
4.60 & 152 & 6.00 & 519 & 7.80 & 871 & 13.00 & 1,530 \\
4.70 & 174 & 6.10 & 546 & 8.00 & 900 & 14.00 & 1,700 \\
4.80 & 196 & 6.20 & 572 & 8.20 & 928 & 15.00 & 1,910 \\
4.90 & 219 & 6.30 & 597 & 8.40 & 956 & 16.00 & 2,190 \\
5.00 & 243 & 6.40 & 621 & 8.60 & 984 & & \\
5.10 & 268 & 6.50 & 644 & 8.80 & 1,012 & & \\
\hline
\end{tabular}

Note.--The above table is not applicable for ice or obstructed-channel conditions. It is based on discharge measurements made during 1903 to 1908 and is well defined. 
Monthly discharge of Mouse River at Minot, N. Dak., for 1907 and 1908.

[Drainage area, 8,400 square miles.]

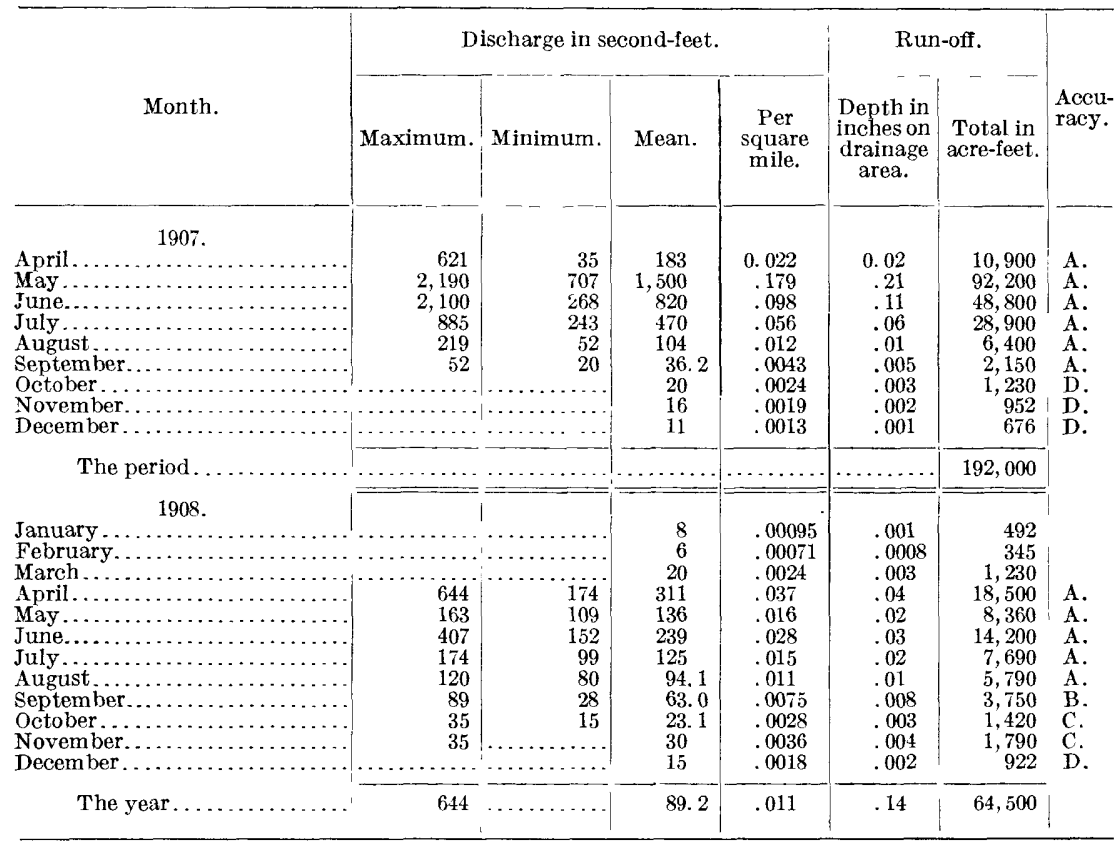

Note.-Discharge has been estimated for period October 1, 1907, to March 31,1908 , and is very approximate, there being only one measurement during the period. Discharge for November 29 to December 31 , 1908 , has been estimated and is only fair. No accuracy values given for January to March; values are only roughly approximate.

EVAPORATION AT INIVERSITY, N. DAK.

The evaporation gage at University, N. Dak., was established April 17, 1905. Daily observations have been made through the whole of the open seasons of 1905 to 1908 , except the first few days of each season before the streams were entirely clear of floating ice cakes, which would interfere with the gage. It is located on a pool in a ravine called English Coulee, which runs through the campus of the University of North Dakota, which is immediately west of Grand Forks, N. Dak., and 2 miles west of the Minnesota boundary.

The coulée drains about 60 square miles of very level prairie. Occasionally, for a few days or hours during the spring thaws, it carries a very large flow. For example, on April 3, 1904, it reached a measured maximum of approximately 1,500 second-feet. Except for such brief freshets, however, the flow is small, varying from 1 secondfoot or less to 10 or 20 second-feet. In very dry weather for several weeks at a time there may be merely a succession of pools with no perceptible flow.

The gage is placed on the largest of these pools, which at extreme low stage has a central depth of 6 feet and an area of at least 30 square 
rods. It is unshaded and there are no large trees in the vicinity. The water surface is ordinarily about 15 feet below the level of the surrounding open prairie, but the banks of the ravine slope so gently (from a top width of 10 or 20 rods or more) that the wind has nearly its normal effect at the gage.

A heavy galvanized-iron tank, 3 feet square and 18 inches deep, is placed in the center of an anchored raft, so that the water in the tank is at the same level as the water surface outside. The tank is filled nearly to the top, to a height precisely marked by the pointed tip of a vertical rod in the center of the tank. Once each day, after the change produced by evaporation or rainfall, the water level is restored to the original height, the precise amount of water transferred being measured with a cup of such size that one cupful of water is equivalent to 0.01 inch depth in the tank.

A standard rain gage is located on the open prairie about 10 rods distant. On days of rainfall the difference (which is usually small) between the quantity measured by the rain gage and the surplus in the tank is considered the total evaporation for the day.

It has been found that the arrangement of this tank is such that the temperature of the water in the tank is always nearly identical with that of the water outside, the difference usually being imperceptible and rarely more than a degree. The temperature of the water and the air have been observed daily, at the same hour as the observation of evaporation, which was regularly between 6 and $7 \mathrm{p}$. m., and the amount of rainfall in the preceding 24 hours (if any) was recorded at the same time.

The evaporation shows great variation from day to day, between a minimum of zero in cold, damp weather, and an ordinary maximum of 0.20 inch to 0.30 inch per day in hot, dry, windy weather. These daily variations can not be satisfactorily discussed without detailed comparison with complete records of wind velocity, cloudiness, and humidity, of which reliable regular observations were not continuously made. The records are therefore arranged in the most convenient form for reference or study, if summarized in ten-day periods.

In the following tables for each ten-day period (one-third of a month) the facts shown are, first, the total evaporation; second, the total rainfall; third, the approximate mean temperature of the water; fourth, the mean observed air temperature. In the years of 1905 and 1906, the air temperatures are not the mean temperatures for the whole day, but merely the temperatures at the hour of observation (usually 6 or 7 p. m.), and are not entirely consistent, since the hour of observation varied slightly; but the increase of evaporation with rise of temperature is clearly shown. The air temperatures as given for the year 1907 are of more value, being the averages of the maximum and minimum thermometer readings for each day.

$22110-$ IRR $245-10-5$ 
Evaporation, rainfall, and temperature at University, N. Dak.

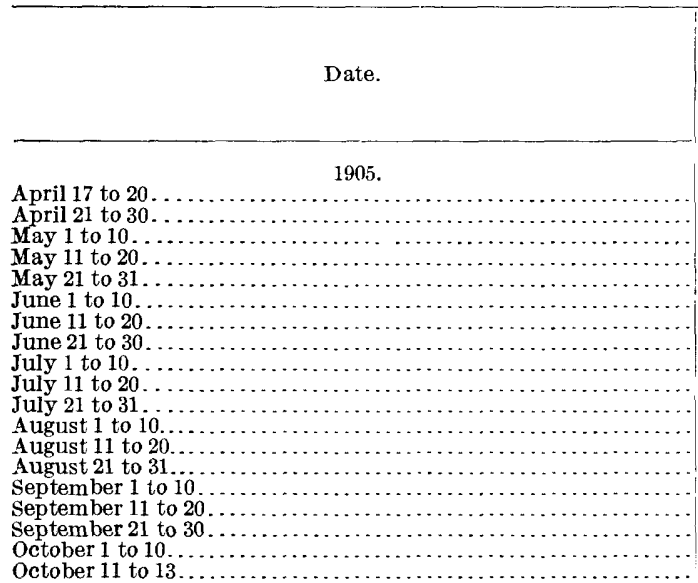

Total, April 17 to October 13.

1906.

April 1 to 10

April 11 to 20

April 21 to 30

May 1 to 10 to 20

May 21 to 31

June 1 to 10

June 11 to 20

June 21 to 30

July 1 to 10

July 11 to 20 .

July 21 to 31 .

August 1 to 10 .

August 11 to 20

August 21 to 31 .

September 1 to 10 .

September 11 to 20

September 21 to 30

October 1 to 10 .

October 11 to 20 .

October 21 to 30

Total, April 1 to October 30

\begin{tabular}{|c|c|c|c|}
\hline \multirow{2}{*}{$\begin{array}{l}\text { Evapo- } \\
\text { ration. }\end{array}$} & \multirow{2}{*}{ Rainfall. } & \multicolumn{2}{|c|}{ Temperature of - } \\
\hline & & Water. & Air. \\
\hline Inches. & Inches. & ${ }^{\circ} F$. & $\circ F$. \\
\hline 0.35 & 0.00 & 32 & 46 \\
\hline 1.43 & .20 & 40 & 56 \\
\hline .67 & 2.57 & 42 & 47 \\
\hline 1. 01 & .73 & 48 & 60 \\
\hline 1.80 & .05 & 53 & 65 \\
\hline 1. 41 & 1. 83 & 56 & 68 \\
\hline 1. 27 & 1. 39 & 59 & 62 \\
\hline 1. 21 & .83 & 59 & 65 \\
\hline 1.64 & .01 & 68 & 71 \\
\hline 2.03 & 2. 31 & 73 & 74 \\
\hline 1.79 & 3. 16 & 69 & 69 \\
\hline 1. 29 & .72 & 71 & 75 \\
\hline 1.37 & 2.55 & 66 & 71 \\
\hline $\begin{array}{l}1.36 \\
1.36\end{array}$ & 1. 27 & 69 & 73 \\
\hline 1.11 & .27 & 61 & 66 \\
\hline 1.05 & .66 & 60 & 61 \\
\hline 1. 59 & .69 & 61 & 66 \\
\hline 1.08 & .01 & 53 & 58 \\
\hline .29 & .00 & 44 & 48 \\
\hline 23.75 & 19. 25 & & \\
\hline .80 & .35 & 43 & 49 \\
\hline 1.32 & 1.44 & $\begin{array}{l}+8 \\
52\end{array}$ & 52 \\
\hline 1.40 & .30 & 60 & 60 \\
\hline 1. 01 & 49 & 55 & 51 \\
\hline 1. 31 & 1. 40 & 60 & 61 \\
\hline 1. 36 & 1.17 & 57 & 57 \\
\hline 1. 16 & .97 & 67 & 68 \\
\hline & 1.39 & 72 & 70 \\
\hline & .73 & 68 & 64 \\
\hline 1.50 & .20 & 74 & 71 \\
\hline 1.42 & 1. 59 & 72 & 67 \\
\hline 1. 91 & .77 & 73 & 72 \\
\hline 1.36 & 15 & 73 & 72 \\
\hline 2. 02 & .30 & 79 & 76 \\
\hline & .64 & 68 & 63 \\
\hline 1.91 & .34 & 75 & 75 \\
\hline 1.04 & 1.07 & 65 & 62 \\
\hline 1.09 & .20 & 61 & 66 \\
\hline .98 & .06 & 52 & 52 \\
\hline .61 & .52 & 51 & 54 \\
\hline .33 & .00 & 39 & 40 \\
\hline $2 \pi .04$ & 14.08 & & \\
\hline .46 & 05 & 39 & 34 \\
\hline 83 & .11 & v & 33 \\
\hline 1. 16 & 45 & 48 & 45 \\
\hline 1. 49 & 07 & 51 & 53 \\
\hline 1.43 & 2.32 & 51 & 57 \\
\hline 1. 51 & .81 & 69 & 65 \\
\hline 1.61 & 1.50 & 76 & 66 \\
\hline 1.95 & 49 & 79 & 67 \\
\hline 2.05 & 1.47 & 79 & 6 \\
\hline 1.99 & .95 & 79 & 65 \\
\hline 1. 36 & .52 & 74 & 6 \\
\hline a 1.63 & .21 & 72 & 60 \\
\hline$a 1.54$ & 1.14 & 70 & 63 \\
\hline a 1.12 & .53 & 66 & 5 \\
\hline 1.04 & 2. 58 & 64 & 5 \\
\hline 1.01 & .75 & & 44 \\
\hline .83 & .42 & & 51 \\
\hline .58 & .00 & & 41 \\
\hline .57 & .22 & & 3 \\
\hline .17 & 0 & & 36 \\
\hline 24.33 & 14. 64 & & \\
\hline
\end{tabular}

April 22 to 30

1907.

May 1 to 10 .

May 11 to 20 .

May 21 to 31 .

June 1 to 10 .

June 21 to 30

July 1 to 10 .

July 11 to 20 .

July 21 to 31

August 1 to 10.

August 11 to 20

August 21 to 31 .

September 1 to 10 .

September 11 to 20 .

October 1 to 10 .

October 11 to 20 .

October 21 to 31

November 1 to 10 .

Total, April 22 to November 10.

$a$ Subject to possible small errors. on account of occasional malicious disturbance of gage, requirlng estimates of evaporation on a few days. 
Evaporation, rainfall, and temperature at University, N. Dak.-Continued.

\begin{tabular}{|c|c|c|c|c|}
\hline \multirow{2}{*}{ Date. } & \multirow{2}{*}{$\begin{array}{l}\text { Evapo- } \\
\text { ration. }\end{array}$} & \multirow{2}{*}{ Rainfall. } & \multicolumn{2}{|c|}{ Temperature of -} \\
\hline & & & Water. & lir. \\
\hline 1908. & Inches. & Inches. & ${ }^{\circ} F$ & ${ }^{\circ} F$ \\
\hline April 15 to $20 \ldots \ldots \ldots \ldots \ldots \ldots \ldots$ & .7 & .30 & 35 & 48 \\
\hline 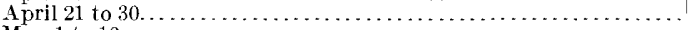 & 1. 49 & .38 & 43 & 47 \\
\hline May 1 to $10 \ldots . . . . . . . .$. & 1. 65 & .00 & 53 & 45 \\
\hline 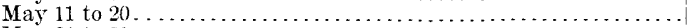 & 1. 32 & 3.32 & 54 & 55 \\
\hline 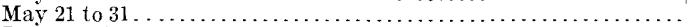 & .86 & .45 & 56 & 54 \\
\hline 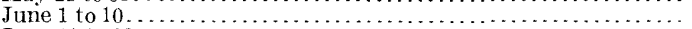 & .79 & .40 & 64 & 63 \\
\hline 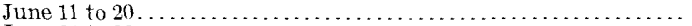 & .74 & 1.60 & 65 & 65 \\
\hline 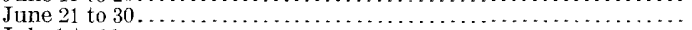 & 1.69 & .70 & 71 & 69 \\
\hline 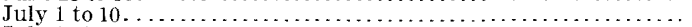 & 2.21 & .02 & 75 & 67 \\
\hline 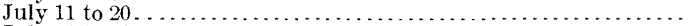 & 1.99 & 1. 00 & $\because$ & 68 \\
\hline$\ldots \ldots \ldots \ldots \ldots \ldots \ldots$ & 2.12 & 1. 45 & 76 & 72 \\
\hline$\ldots \ldots \ldots \ldots \ldots \ldots \ldots \ldots \ldots \ldots$ & 2.22 & .00 & 71 & 68 \\
\hline 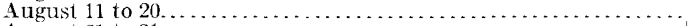 & 1.89 & .00 & 69 & 62 \\
\hline$\ldots \ldots \ldots \ldots \ldots \ldots \ldots \ldots \ldots$ & 1. 66 & 2.41 & 65 & 64 \\
\hline 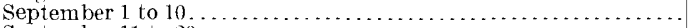 & 1.70 & .00 & 68 & 65 \\
\hline 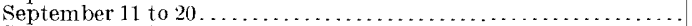 & 1. 47 & .00 & 68 & 70 \\
\hline September 21 to $30 \ldots . .$. & 1.07 & .50 & 39 & 50 \\
\hline$\ldots \ldots \ldots \ldots \ldots \ldots \ldots \ldots \ldots$ & $.6 \vec{\imath}$ & .15 & 47 & 51 \\
\hline$\ldots \ldots \ldots \ldots \ldots \ldots \ldots \ldots \ldots \ldots$ & .62 & .21 & 44 & 51 \\
\hline 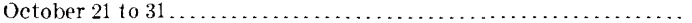 & .29 & .26 & 35 & 35 \\
\hline 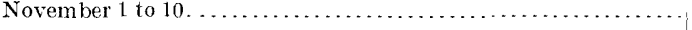 & .19 & .01 & 32 & 35 \\
\hline Total, April 15 to November 10. & $2 خ .11$ & 13.16 & & \\
\hline
\end{tabular}

To summarize in the briefest form for the four rear's 1905 to 1908:

During the warm seasons of 180 dars, 213 days, 203 days, and 210 days the total evaporations were 23.75 inches, 27.04 inches, 24.33 inches, and 27.41 inches respectively; expressed in daily averages, these figures are equivalent to means of 0.132 inch, 0.127 inch, 0.120 inch and 0.131 inch per day for the four seasons, the smaller average for 1907 resulting from the fact that that year was colder than the normal.

During nearly all the remainder of each year water surfaces were frozen, and it was not convenient to make reliable evaporation observations. There is a very considerable evaporation from ice surfaces, and if-including the many days when the ice surface is thawing and being rapidly dissipated in vapor, and the few days of the open season before observations were begun-the mean evaporation for this period be estimated as between 0.030 and 0.070 inch per day, the total evaporation during the time not observed would be between 5 and 11 inches, making the total annual evaporation between 30 and 36 inches.

The latitude of this place is $48^{\circ}$, its elevation above sea level 820 feet, and its normal rainfall about 20 inches a year.

The conditions at the gage are such that the results may be considered as fairly representative of those to be obtained at any stream or reservoir in the region. 


\section{UPPER MISSISSIPPI RIVER DRAINAGE.}

\section{GENERAL DESCRIPTION.}

Mississippi River drains the greater part of the territory of the United States lying between the Allegheny and the Rocky Mountains. Its basin, irregular in shape, occupying the central part of the United States, is best described as an oblong, with the major axis, 1,700 miles in length, running southeastward from the northwestern part of Montana, through North Dakota, Nebraska, Missouri, and Tennessee, into the northwestern corner of Alabama. On each side of this line the basin spreads out from 300 to 500 miles, while on the east is a large proturberance from the general outline extending to the Alleghenies. The basin comprises about 1,240,000 square miles, and includes wholly or in part 30 States, besides a small area in the Dominion of Canada. Of the total area, about 527,000 square miles drain to the Missouri, about 171,500 square miles to the upper Mississippi above the mouth of the Missouri, and about 204,000 square miles to the Ohio. The mean annual flow of the Missouri is about 100,000 second-feet; of the upper Mississippi, about 125,000 second-feet; of the Ohio, about 300,000 second-feet.

Immediately beneath the covering of drift at the sources of the Mississippi lie the oldest rocks known to the geologist. Its mouth is surrounded by the soft marshes of its own delta now forming. Between these two extremes rocks of all geologic ages are represented.

All varieties of topography are likewise exhibited in the drainage basin, mountain and prairie, arid plain, and alluvial bottom covered with vegetation being fully represented; but the greater part of its broad extent is very uniform in contour.

For convenience in publication the basin of the Mississippi River has been divided into upper Mississippi, Missouri River, lower Mississippi, and Ohio drainage basins. The upper Mississippi basin, as considered in this discussion, is that portion lying above the mouth of the Missouri. The upper Mississippi basin therefore occupies the north-central part of the United States, including Minnesota, Wisconsin, Iowa, Illinois, Indiana, Missouri, and a few square miles in South Dakota and the northern peninsula of Michigan. Thesources of this branch of the great river are almost exactly in the center of the continent on an east and west line.

The Mississippi rises, not in Lake Itasca, so long considered the source, but in a smaller lake which drains into Lake Itasca, called Hernando de Soto, situated in the northeastern part of Becker County, Minn. From these lakes to the mouth of Crow Wing River it flows almost in a circle, as at this point it is only 75 miles from its sources, while the distance following the river is about 450 miles. Leaving the lakes its course is northward, but below the junction with the 
Crow Wing it turns to the south and continues in this direction until it finally reaches the Gulf of Mexico.

The total length of the river is about 2,555 miles; from the source to the mouth of the Ohio is about 1,500 miles. ${ }^{a}$

The important tributaries of the upper Mississippi beginning at the source and following down the west bank are: Leech Lake, Willow, Pine, Crow Wing, Sauk, Minnesota, ('annon, Turkey, Wapsipinicon, Iowa, Des Moines, and Missouri rivers. On the east bank are: Prairie, Elk, Rum, St. Croix, Chippewa, Black, La Crosse, Wisconsin, Rock, Illinois, Kaskaskia, Big Muddy, and Ohio sivers.

From Lake Ifernando de Soto to the Falls of St. Anthony the river flows almost exclusively through a drift-covered region. Down to Pokegama Falls it occupies a valley which is in some places narrow, in others broad and savanna-like, with many rapids in the narrower and with gentle or sluggish currents in the broader portions. In this part of its course it drains a number of lakes, among which Bemidji, Cass, Winnibigoshish, and Leech are the most important. The total fall from the head of the stream to the mouth of Leech Lake River, which is nearly as large as the main stream, is about 420 feet. The first rock in place is at Pokegama Falls, and thence to the mouth of Crow Wing River, which enters from the west, the average width of the stream is 300 feet, the valley is less winding, and the current is good, with many rapids of small extent.

Below the mouth of the Crow Wing the river flows in a general southeasterly direction for about 475 miles. Within this stretch are several rapids - the chief being Little Falls and Sauk Rapids-and many timbered islands. The banks are abrupt, of clay or sandy loam, and lead to mearlows that stand 60 feet above the river. At the falls of St. Anthony the river pitches down a vertical fall and rapids amounting to 75 feet in half a mile, and in so doing leaves the prairie and clay banks for a channel that lies between rocky bluffs of limestone and sandstone, which continue for many miles down the river, gradually increasing to a height of 500 feet as the bed sinks below the general prainie level. The sides of the bluffs are not vertical, bare surfaces of rock, but are composed of easily eroded stone and drift, which form well-wooded or grassy slopes.

Minnesota River, formerly called St. Peters River, enters the Mississippi about 10 miles below St. Anthony Falls, and below its mouth the breadth of the main stream averages 1,000 feet. From this point to the mouth of the Missouri it is a broad, placid stream with innumerable islands, the entire width of the valley averaging 1 mile. In many

$a$ The Twenty-Second Annual Report of the United States Geological Survey, Pt. IV, p. 210, contains a detailed description of the Mississippi from the sources to St. Paul, taken from the Reports of the Chief of Engineers, I. S. Army. The hydrographic investigations of the United States Engineer Corps on the upper Mississippi extend over a period of thirt $y-1$ wo years, from 1866 to 1898 , and form, according to the Report of the Chief of Engineers for 1897, "the largest continuous record over large drainage areas that has been made in the United States." 
places, especially where tributaries enter, fertile flats lie between the river and the bluffs. Fifty-five miles below the mouth of the Minnesota is Lake Pepin, an expansion of the river apparently caused by the immense quantities of sand brought down by the Chippewa. At two places exceptions occur to the otherwise placid character of the river. At Rock Island, Ill., 384 miles from St. Paul, there are rapids by which the river falls 20.4 feet in 12 miles; and at Keokuk, Iowa, 509 miles from St. Paul, is the foot of the Des Moines Rapids, where in a distance of 11 miles the river falls 21.85 feet.

The elevation of the sources of the river is approximately 2,000 feet; at St. Paul, Minn., the elevation is 690 feet; at Clinton, Iowa, 570 ; at St. Louis, Mo., 385; at Cairo, Ill., the elevation is 275 feet.

The headwaters of the main stream and its tributaries which lie in Wisconsin and Minnesota may be said to be in a forested area; that part of the drainage basin outside of Minnesota and Wisconsin is deforested; a great portion consists of prairie land.

The mean annual rainfall in the upper Mississippi basin is about 30 inches, ranging from 35 inches at the northern boundary to about 40 inches in the southern part of the basin. The winter conditions in Wisconsin, Minnesota, and Iowa are severe, snowfall is heavy and lasts for considerable periods, ice forms to a thickness of 1 to 2 feet, and lasts for three to four months. In other parts of the drainage basin the winters are milder.

According to some authorities, the basin of the upper Mississippi contains from 5,000 to 6,000 lakes, nearly all of which are near the sources of the main river and its northern tributaries, and which, with the numerous swamps, produce a natural storage steadying the flow of the river. By building dams of ordinary height it is possible to create large reservoirs at many of these lakes. The Army Engineer Corps has built and is successfully operating a few reservoirs at the headwaters of the Mississippi River as an aid to navigation.

The basin affords numerous opportunities for water-power development, especially on those tributaries in the States of Wisconsin and Minnesota. (See Pls. III, $B$, IV, and V.) There are valuable power sites on the main stream, the more important of which are utilized or about to be.

The following gaging stations have been maintained on the Mississippi River and the minor tributaries. Those on the principal tributaries are given elsewhere.

Mississippi River near Sauk Rapids, Minn., 1903-1906.

Mississippi River at Anoka, Minn., 1905-1908.

Mississippi River at St. Paul, Minn., 1895-1901.

Crow Wing River at Pillager, Minn., 1903.

Minnesota River near Mankato, Minn., 1903-1906.

Crow River near Dayton, Minn., 1906.

Maquoketa River at Manchester, Iowa, 1903. 


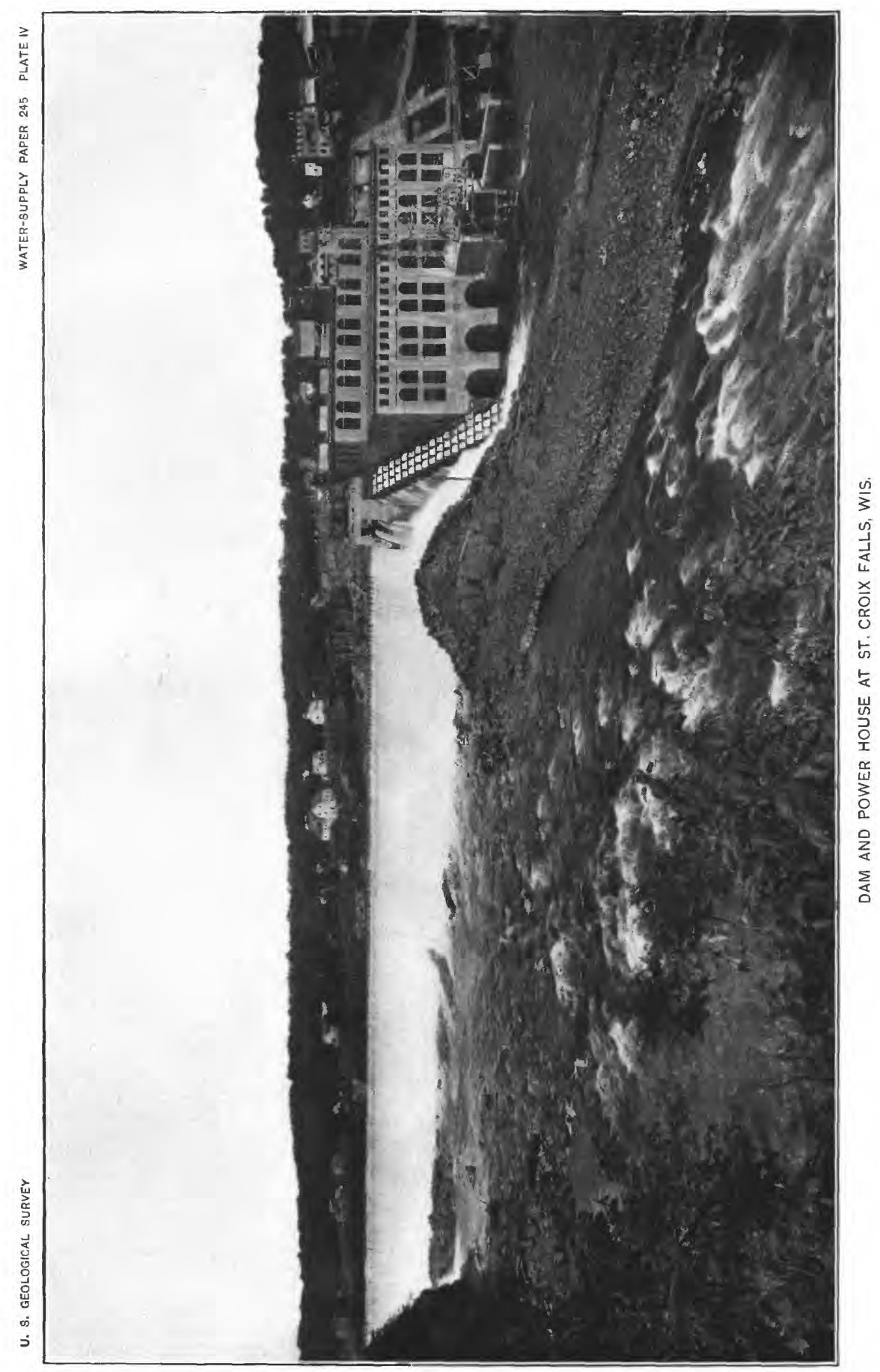




\section{MISSISSIPPI RIVER AT ANOKA, MINN.}

This station, which is located at the highway bridge in the southwestern part of Anoka, Minn., was established May 8, 1905, to obtain data for use in studying water power, water supply, pollution, flood control, storage, and navigation problems.

The drainage area above the section is about 17,300 square miles. Rum River enters on the left bank about one-half mile below the station.

Winter conditions are severe at this station. Ice forms to a thickness of about 2 feet and lasts from three to four months, but the section is generally open at one or two places during the ice period. Logging operations, for which the river is extensively used, may affect the gage readings to a small extent. Portions of the river bed are occasionally covered with sunken logs, but these probably have little or no effect on the gage heights.

The gage reader at this station has been paid by the Great Northern Development Company of Duluth, Minn., since August, 1906.

The gage was originally established in 1896 by the army engineers. The datum of the gage has remained unchanged.

No measurements have been taken at this station since 1906 .

Daily gage height, in feet, of Mississippi River at Anoka, Minn., for 1907 and 1908.

[Ross Cutler and Bernard Witte, observers.]

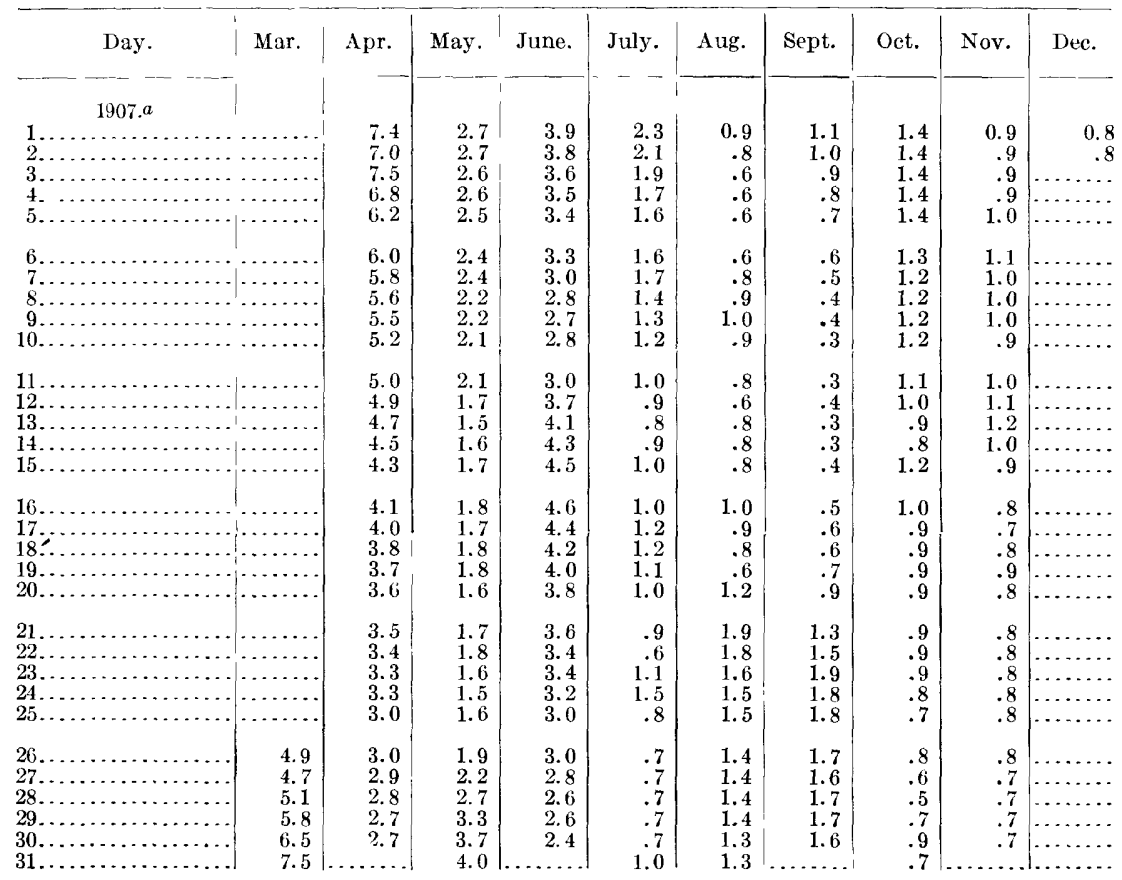

$a$ Ice conditions January 1 to March 25 and December 3 to $31,1907$. 
Daily gage height, in feet, of Mississippi River at Anska, Minn., for 1907 and 1908-Con.

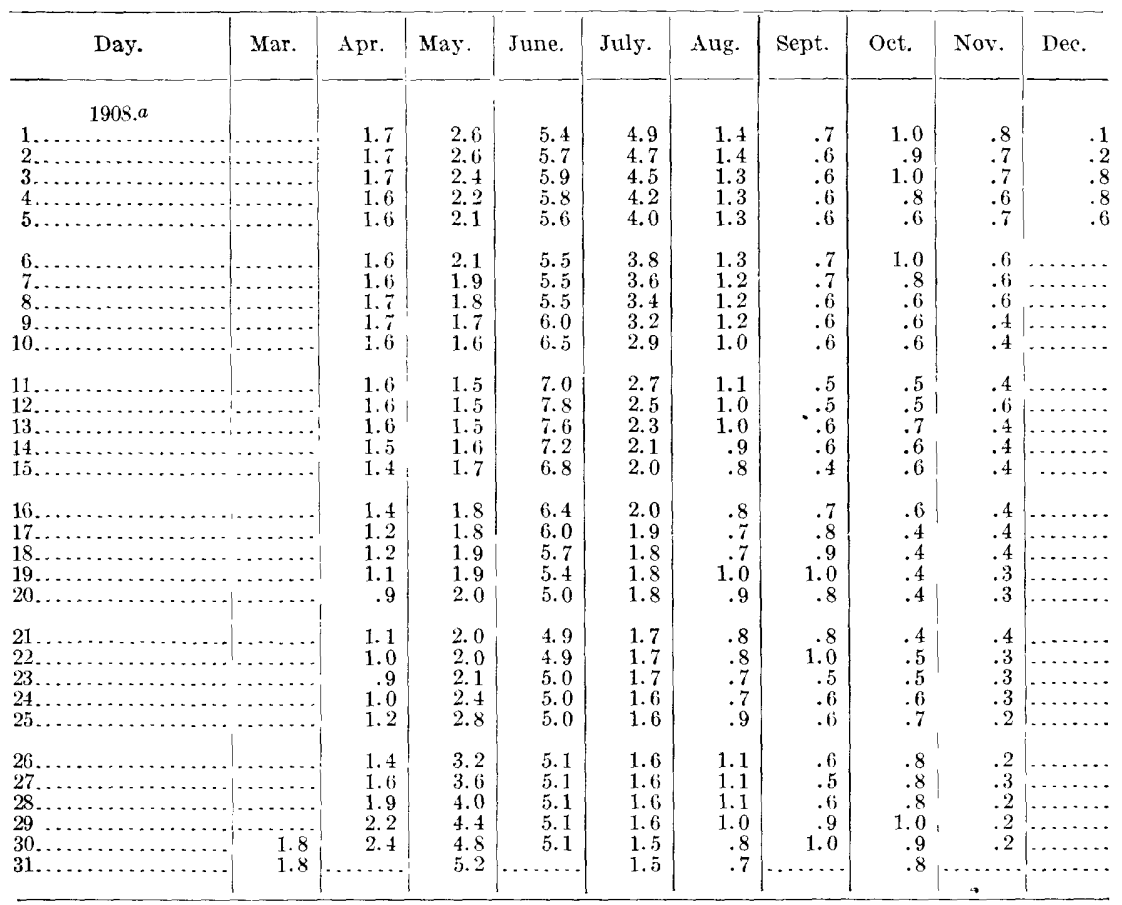

$a$ Ice conditions January 1 to March 28 and November 30 to December 31, 1908.

\section{CHIPPEWA RIVER DRAINAGE BASIN.}

\section{DESCRIPTION.}

Chippewa River drainage system has its sources in more than a hundred lakes, large and small, with many connecting swamps, lying in the northwestern part of the State of Wisconsin, near the Michigan boundary and only 20 miles from Lake Superior. The main line of drainage runs very nearly along the central line of the basin, but the name of Chippewa River is not applied to the continuation of the main stream. The river dirides 112 miles from the mouth. One branch, the prolongation of the line of drainage, called the Flambeau, rises in the lakes near the Michigan line, at an elevation of a little over 1,600 feet above sea level; the other branch, the Chippewa, is formed in the central part of Sawyer County, by the union of East and West branches, both of which rise in the southwestern part of Ashland County. The course of the river is general southwestward to its junction with the Mississippi at the foot of Lake Pepin. The Flambeau drains about 1.983 square miles, while the Chippewa above its junction with the Flambeau drains only about 1,777 square miles.

The important tributaries of the Chippewa are as follows: From the west, beginning at the sources, West Branch and Red Cedar 
rivers; from the east are East Branch, Thornapple, Flambeau, Jump, Yellow, and Eau Claire rivers.

The total length of the Chippewa is 267 miles. The total drainage area is about 9,573 square miles, of which over 6,000 square miles include the most unsettled region of northern Wisconsin.

The drainage basin is regular in outline and shape, being about 180 miles long and about 60 miles in average width. The entire area above Chippewa Falls is covered with glacial drift, and the underlying crystalline rocks appear only in the river bed. In the southern part of the bed the rivers have eroded deeply into the drilt and rock, but in the northern districts they have not cut much below the surface. The country is level or rolling.

With but few exceptions all the many and important water powers on Chippewa River are found in the region of crystalline rocks, but on account of the deep glacial drift the powers on the upper streams occur as bowlder rapids.

The lakes in this drainage basin are situated in two widely separated groups; one in the extreme northeastern part at the headwaters of the Flambeau, the other in the northwestern part at the headwaters of Chippewa and Red Cedar rivers. The remainder of the area is almost devoid of lakes. The wooded regions, however, include very large areas of cedar and tamarack swamps. The sources of Chippewa River have an elevation of about 1,500 feet above sea level; at Chippewa Falls it is 806 feet; and at the mouth of the river the elevation is about 665 feet. The elevation of the sources of Flambeau River is about 1,650 feet; at Ladysmith the elevation is 1,115 feet.

This drainage basin contains the richest forests of both hard and soft woods. Although lumbering has been carried on actively for many years, considerable pine timber still remains, chiefly at the upper headwaters, but it is fast disappearing. The upper half of the drainage basin may be considered forested area.

The mean annual rainfall is about 30 inches. The winters are severe. The snowfall is heavy and lasts for long periods; ice forms on the streams about 2 feet in thickness and remains for three to four months.

This drainage area affords an unusual number of excellent sites for reservoirs. According to surveys made by the United States Fngineer Corps in 1880, twelve reservoir sites were located and surveyed, whose total capacity was approximately 25 billion cubic feet. The highest dam necessary was about 26 leet. The operation of these reservoirs, it was estimated, would increase the ordinary low-water flow of the river by 3,245 second-feet for ninety days, thus about doubling the present available water power of the river. The main obstacle to building such reservoirs at the present time by the Government is the fact that, owing to the settling of this region, the land that would be flooded has become very valuable. Private enterprise has developed some of the smaller of these reservoirs. 
Several valuable developed water powers and numerous undeveloped power sites are located on this river and its tributaries. The Dells Paper and Pulp Company's plant near Eau Claire has a turbine installation of over 8,000 horsepower, and plans have been made to increase the head from 26 to 32 feet by increasing the height of the dam. On the Flambeau and Red Cedar exceptionally good power sites exist. Near Ladysmith, on the Flambeau, are two developments, one of which has a rated turbine installation of 3,000 horsepower. In a 30-mile stretch of Red Cedar River there are six sites for water power capable of developing about 13,000 horsepower. On account of the numerous lakes in the drainage basin of the Chippewa, with the possibility of using them for storage, this river system is destined to become a great center of power, but the development of the numerous power sites is retarded by the fact that at the present time the section is not thickly settled and railroad facilities are lacking in many portions.

The river and its tributaries are used extensively for running logs, but in the areas where there are railroads, the logs are moved by rail, as it has been found that the rivers can not compete with railroad transportation for $\mathrm{log}$ running. The extension of railroad facilities in this section will tend to relieve the river of its burden of logs and correspondingly add to the value of the river for water power.

The use of the river for flooding logs modifies the normal flow of the river very materially.

The following gaging stations have been maintained in this drainage basin:

Chippewa River at Chippewa Falls, Wis., 1899-1908.

Chippewa River near Eau ('laire, Wis., 1902-1908.

Flambeau River near Ladysmith, Wis., 1903-1906.

Red cedar River at Menominee, IV is., 1907-1908.

FLAMBEAU RIVER SURVEY.

In order to point out the power possibilities along Flambeau River, a survey was male during 1906 from Flambeau to a point near the western border of Lac Du Flambeau Indian Reservation; the section from the mouth to Flambeau had been surveyed by the Geological Survey in 1902. From the data collected sheets have been prepared showing a profile of the water surface, a plan of the river, contour along the bank, and prominent natural or artificial features. The results of this survey have been published on separate sheets, and may be had on application to the Director of the Geological Survey.

\section{CHIPPEWA RIVER AT CHIPPEWA FALLS, WIS.}

This station is located at the highway bridge at Chippewa Falls, Wis. The gage was originally established by the Chippewa Lumber and Boom Company, in April, 1899, and records of gage heights since that time have been obtained by that company. The gage heights 
as originally recorded are in feet and inches, but have been reduced to feet and hundredths. On June 1, 1906, the United States Geological Survey began taking discharge measurements at this place to determine the amount of water arailable for water power and storage, and to obtain data of value in general statistical and comparative studies of run-off. The United States Weather Bureau has obtained gage-height records for this station beginning with 1904, and the gage heights as furnished by them have been used for March to September, 1905, 1907, and 1908.

The dam of the Chippewa Lumber and Boom Company is about 2,500 feet abore the station.

The winters are severe in this vicinity, and ice forms on the river about 2 feet in thickness; but considerable open water is found at the measuring section, owing to the swift water and the proximity of the dam. The river fluctuates very rapidly at times during the "sawing season" on account of the storage and release of water at a reservoir at IIolcombe, some 30 miles above. The stored water is used to flood $\log \mathrm{s}$ to the sawmill.

The normal flow of the stream is much modified by logging and the power plants at Chippewa Falls, which cause great and rapid fluctuations in stage from day to day. The datum of the gage has remained unchanged.

Conditions of flow appear to be permanent, and an excellent rating curve has been developed. (See fig. 1.)

Information in regard to this station prior to 1908 is contained in Bulletin XX of the Wisconsin Geological and Natural IIistory Survey, entitled "Water powers of Wisconsin," by Leonard S. Smith.

Discharge measurements of (hippeua River at thippewa Falls, Wis., 1906 to 1908.

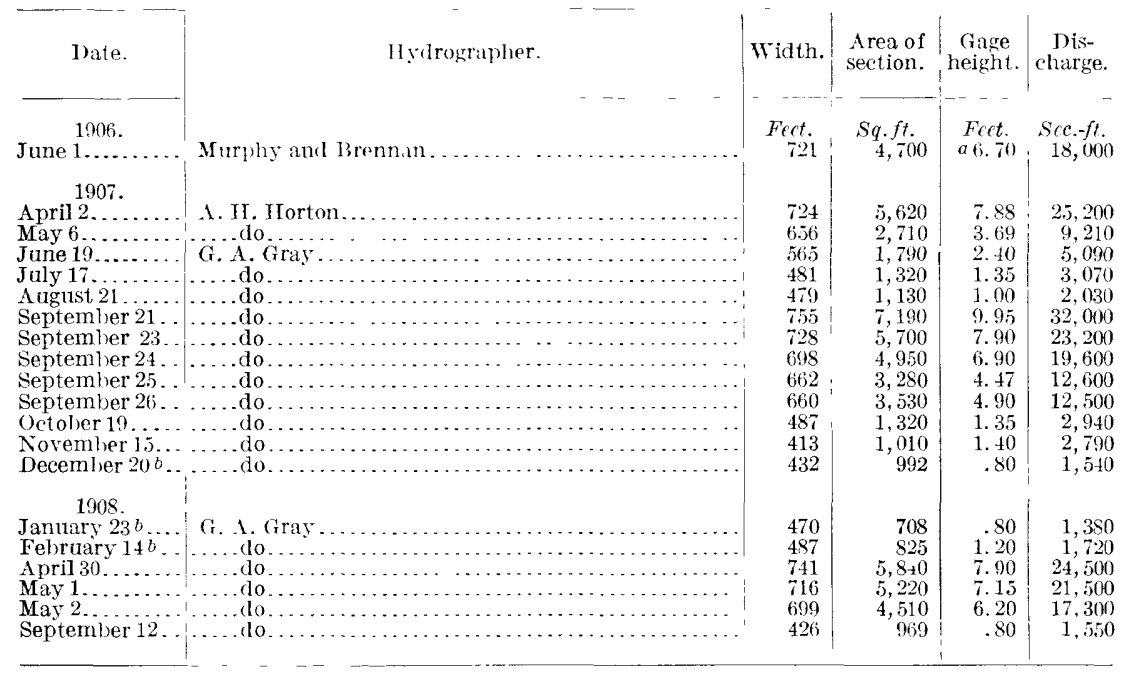


Daily gage height, in feet, of (hippewa River at Chippeua Falls, Wis., for 1899 to 1908.

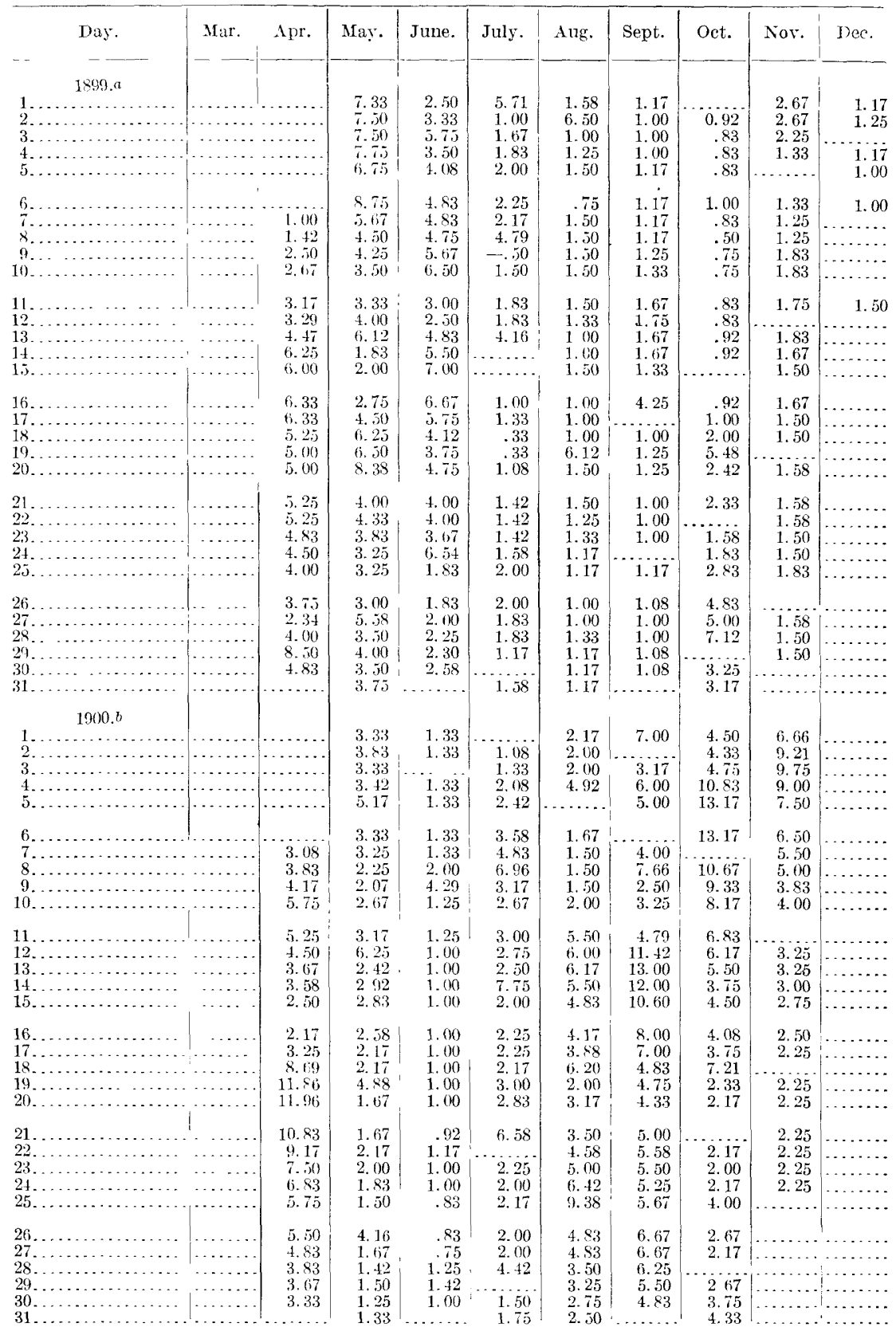

$a$ Ice conditions January 1 to $A$ pril 9 and ahout Decemier 1 to 31,1899 .

$b$ Ice conlitions January 1 to April 7 and probably November 25 to December $31,1900$. 
Daily gage height, in feet, of Chippewa River at Chippewa Falls, Wis., for 1899 to $19(18$ - Continued.

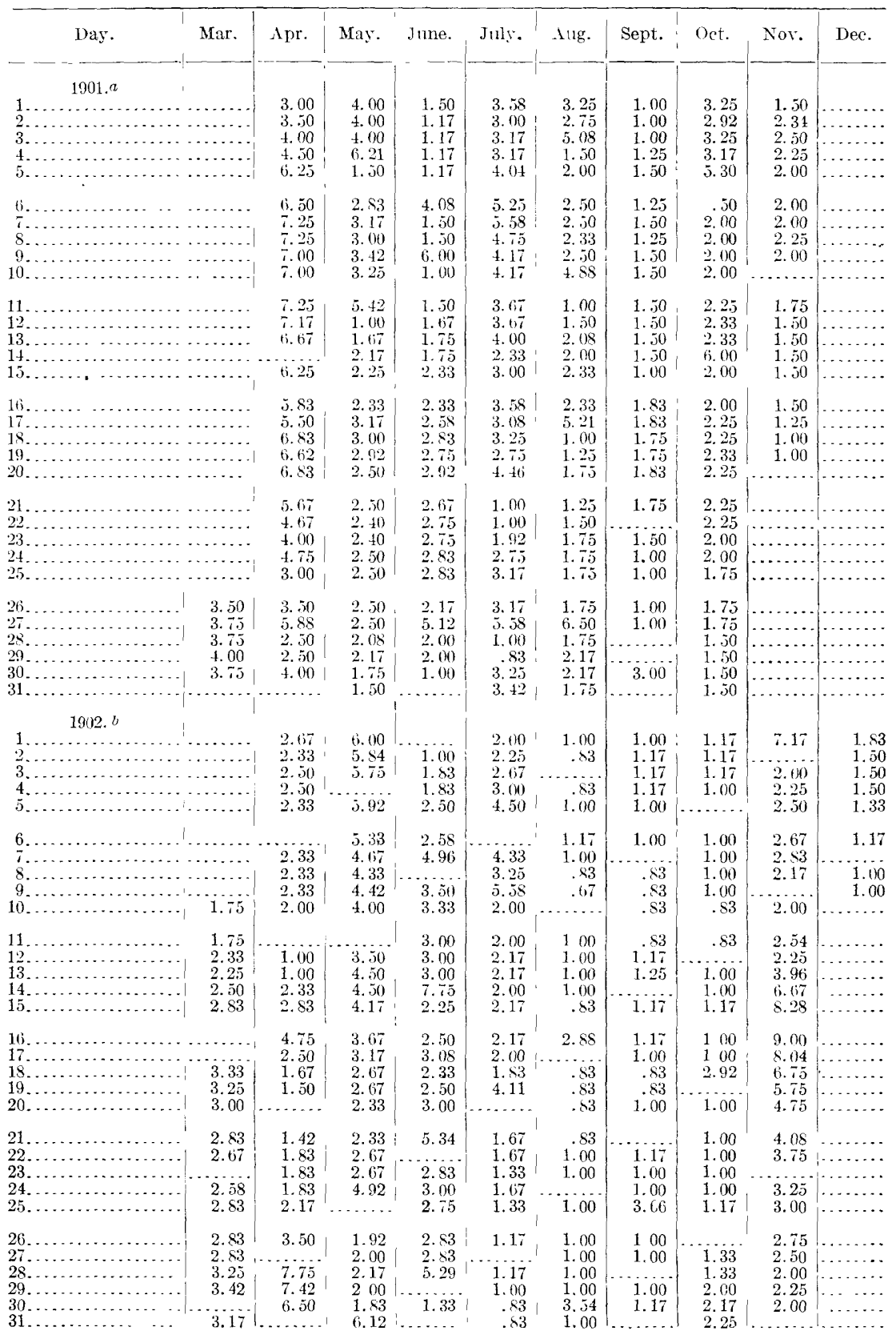

$a$ Ice conditions probably prevailed from January 1 to March 25 and November 20 to Jecember 31, 1901. ${ }^{b}$ Ice conditions prevailed from January 1 to March 9 and December 10 to 31,1902 . There may also have been some slight effect from ice during the rest of March and December. 
Daily gage height, in feet, of Chippewa River at Chippewa Falls, Wis., for 1899 to 1908-Continued.

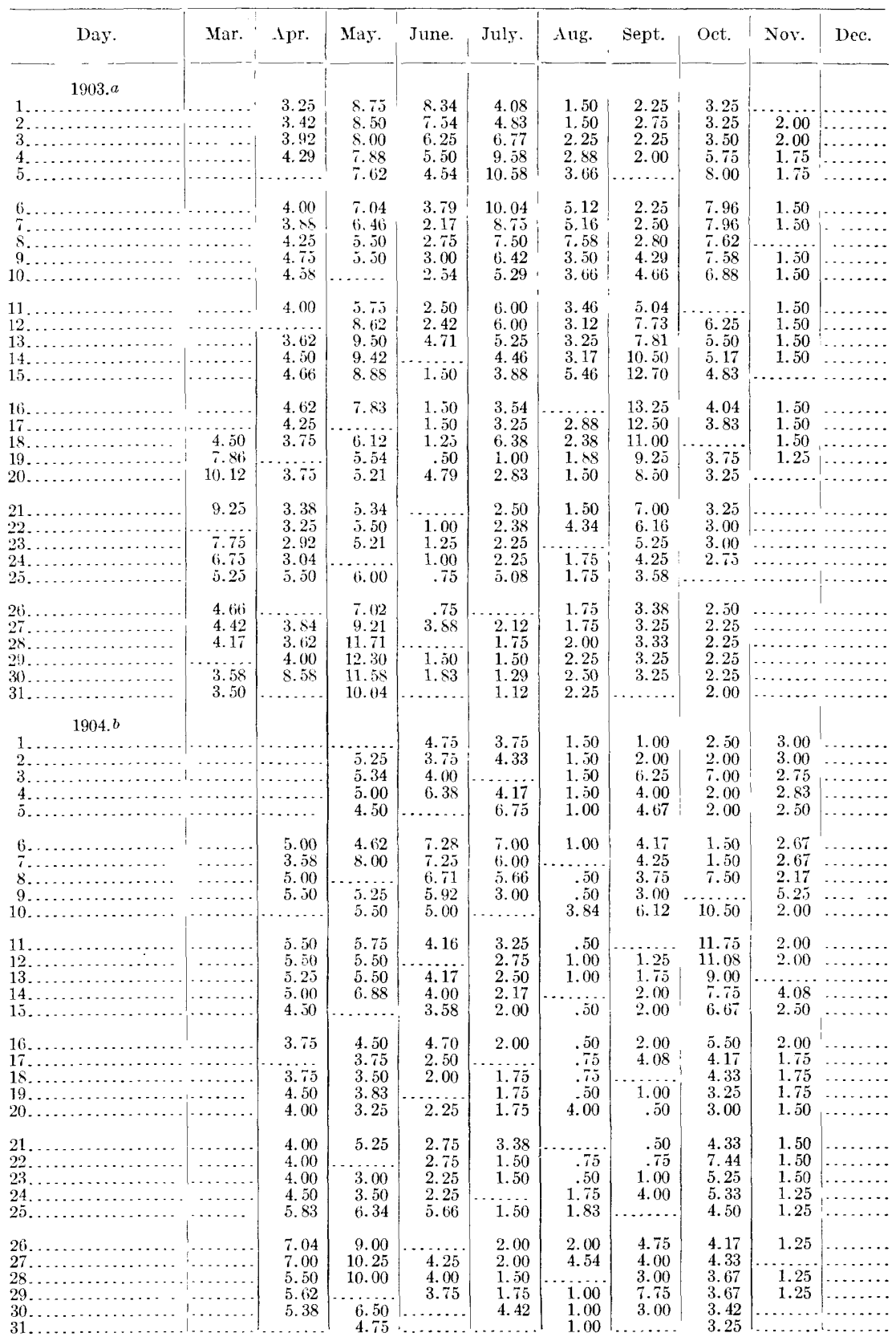

a Ice conditions prevailed from January 1 to March 19 and probably from Norember 19 to December 31, 1903.

$b$ Ice conditions prevailed from January 1 to April 6 and from November 30 to December 31,1904 . 
Daily gage height, in feet. of Chippeua River at Chippewa Falls, Wis., for 1899 to 1908 -Continued.

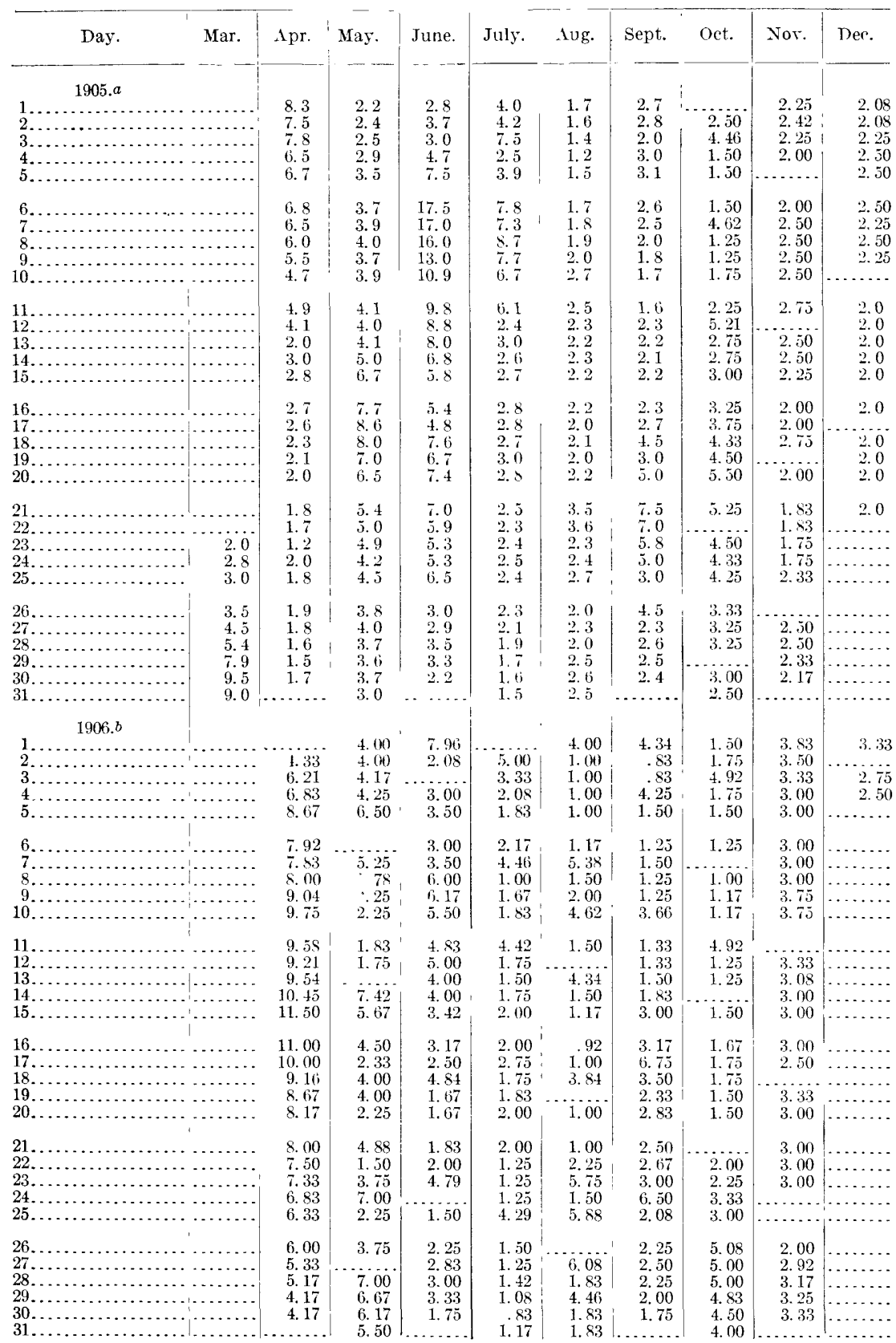

$a$ No notes regarding ice conditions are arailable. Ice conditions are assumed to have prevailed from January 1 to March 22 and December 22 to 31,1905 .

$b$ The above gage heights for 1906 supersede those published in Water-Supply Paper 207, and are considered to give somewhat better results when compared with the discharge at Fau Claire. Ice conditions prevailed from January 1 to March 31 and throughout the greater portion of December, 1906. 
Daily gage height, in feet, of Chippewa Falls at Chippewa Falls, Wis., for 1899 to 1908-Continued.

[N. O. Swift, observer, 1907 and 1908.]

\begin{tabular}{|c|c|c|c|c|c|c|c|c|c|c|}
\hline Day. & Mar. & Apr. & May. & June. & July. & Aug. & Sept. & Oct. & Nov. & Dee. \\
\hline $\begin{array}{c} \\
1 \\
1 \ldots \ldots \\
2 \ldots \ldots \\
3 \ldots \ldots \\
4 \ldots \ldots \\
5 \ldots \ldots\end{array}$ & & $\begin{array}{l}9.5 \\
8.0 \\
7.5 \\
7.3 \\
8.0\end{array}$ & $\begin{array}{l}3.9 \\
4.0 \\
3.9 \\
4.2 \\
4.0\end{array}$ & $\begin{array}{l}4.0 \\
3.9 \\
3.5 \\
3.4 \\
3.3\end{array}$ & $\begin{array}{l}2.2 \\
2.1 \\
2.2 \\
2.3 \\
3.2\end{array}$ & $\begin{array}{l}1.0 \\
1.1 \\
1.2 \\
1.0 \\
1.2\end{array}$ & $\begin{array}{r}0.8 \\
.9 \\
.8 \\
.7 \\
.8\end{array}$ & $\begin{array}{l}2.8 \\
2.8 \\
2.0 \\
1.7 \\
1.9\end{array}$ & $\begin{array}{l}1.3 \\
1.4 \\
1.4 \\
1.4 \\
1.3\end{array}$ & $\begin{array}{r}0.9 \\
.9 \\
.9 \\
.9 \\
.9\end{array}$ \\
\hline $\begin{array}{r}6 \ldots \ldots \\
7 \ldots \ldots \\
8 \ldots \ldots \\
9 \ldots \ldots \\
10 \ldots\end{array}$ & & $\begin{array}{l}7.9 \\
7.5 \\
6.9 \\
6.6 \\
5.5\end{array}$ & $\begin{array}{l}3.9 \\
3.8 \\
3.9 \\
3.8 \\
3.7\end{array}$ & $\begin{array}{l}2.5 \\
3.0 \\
3.3 \\
2.7 \\
2.5\end{array}$ & $\begin{array}{l}3.5 \\
2.9 \\
2.4 \\
2.3 \\
2.1\end{array}$ & $\begin{array}{l}1.3 \\
1.2 \\
1.3 \\
1.2 \\
1.3\end{array}$ & $\begin{array}{l}.7 \\
.8 \\
.7 \\
.6 \\
.7\end{array}$ & $\begin{array}{l}1.7 \\
1.8 \\
1.5 \\
1.4 \\
1.5\end{array}$ & $\begin{array}{l}1.4 \\
1.5 \\
1.3 \\
1.1 \\
1.1\end{array}$ & $\begin{array}{l}1.0 \\
1.0 \\
1.0 \\
1.0 \\
1.0\end{array}$ \\
\hline $\begin{array}{l}14 \ldots \ldots \\
15 \ldots \ldots\end{array}$ & . & $\begin{array}{l}5.4 \\
5.0 \\
5.2 \\
4.4 \\
4.3\end{array}$ & $\begin{array}{l}3.7 \\
5.5\end{array}$ & $\begin{array}{l}2.5 \\
2.8\end{array}$ & $\begin{array}{l}2.2 \\
1.9 \\
1.7 \\
1.6 \\
1.4\end{array}$ & $\begin{array}{l}1.2 \\
1.1 \\
1.3 \\
1.1 \\
1.0\end{array}$ & $\begin{array}{l}.8 \\
.9 \\
.8 \\
.7 \\
.8\end{array}$ & $\begin{array}{l}1.3 \\
1.3 \\
1.3 \\
1.7 \\
1.7\end{array}$ & $\begin{array}{l}1.3 \\
1.3 \\
1.3 \\
1.4 \\
1.4\end{array}$ & $\begin{array}{l}1.0 \\
1.0 \\
1.0 \\
1.0 \\
1.0\end{array}$ \\
\hline $\begin{array}{l}16 \ldots \ldots \\
17 \ldots \ldots \\
18 \ldots \ldots \\
19 \ldots \ldots \\
20 \ldots \ldots\end{array}$ & $\begin{array}{l}2.0 \\
1.8 \\
1.7 \\
2.2\end{array}$ & $\begin{array}{l}4.2 \\
3.9 \\
3.8 \\
3.6 \\
3.5\end{array}$ & $\begin{array}{l}5.9 \\
6.6\end{array}$ & $\begin{array}{l}2.4 \\
2.5 \\
2.3\end{array}$ & $\begin{array}{l}1.5 \\
1.6 \\
1.4 \\
1.6 \\
1.7\end{array}$ & $\begin{array}{r}1.1 \\
1.0 \\
.9 \\
1.0 \\
1.2\end{array}$ & $\begin{array}{r}.9 \\
1.0 \\
1.1 \\
4.0 \\
8.3\end{array}$ & $\begin{array}{l}1.8 \\
1.5 \\
1.3 \\
1.3 \\
1.4\end{array}$ & $\begin{array}{l}1.4 \\
1.5 \\
1.4 \\
1.4 \\
1.4\end{array}$ & $\begin{array}{l}1.0 \\
1.0 \\
1.0 \\
1.0 \\
1.0\end{array}$ \\
\hline $\begin{array}{l}21 \ldots \\
22, \ldots \\
23 \ldots \\
24 \ldots \\
25 \ldots\end{array}$ & $\begin{array}{l}2.3 \\
2.5 \\
3.5 \\
4.0 \\
4.5\end{array}$ & $\begin{array}{l}3.4 \\
3.3 \\
2.9 \\
2.8 \\
3.6\end{array}$ & $\begin{array}{l}5.2 \\
4.8 \\
4.5 \\
4.3 \\
4.7\end{array}$ & $\begin{array}{l}2.2 \\
2.1 \\
2.2 \\
2.4 \\
3.4\end{array}$ & $\begin{array}{l}1.3 \\
1.9 \\
1.8 \\
1.6 \\
1.5\end{array}$ & $\begin{array}{l}1.3 \\
1.2 \\
1.1 \\
1.0 \\
1.1\end{array}$ & $\begin{array}{r}10.0 \\
9.5 \\
8.4 \\
7.3 \\
4.3\end{array}$ & $\begin{array}{l}1.5 \\
1.5 \\
1.5 \\
1.5 \\
1.3\end{array}$ & \begin{tabular}{l|}
1.3 \\
1.3 \\
1.3 \\
1.2 \\
1.2
\end{tabular} & $\begin{array}{l}.9 \\
.9 \\
.9 \\
.9 \\
.9\end{array}$ \\
\hline $\begin{array}{l}26 \ldots \\
27 \ldots \\
28 \ldots \\
29 \ldots \\
30 \ldots \\
31 \ldots\end{array}$ & $\begin{array}{r}6.5 \\
7.0 \\
9.0 \\
10.0 \\
11.0 \\
10.9\end{array}$ & $\begin{array}{l}4.0 \\
3.8 \\
3.9 \\
3.8 \\
4.0 \\
\cdots . .\end{array}$ & $\begin{array}{l}4.9 \\
4.4 \\
4.7 \\
3.5 \\
4.0 \\
4.1\end{array}$ & $\begin{array}{l}3.0 \\
2.7 \\
2.9 \\
2.4 \\
2.3\end{array}$ & $\begin{array}{l}1.3 \\
1.2 \\
1.1 \\
1.0 \\
1.7 \\
1.0\end{array}$ & $\begin{array}{r}1.0 \\
.9 \\
1.0 \\
.9 \\
.8 \\
.9\end{array}$ & $\begin{array}{l}6.9 \\
4.2 \\
4.7 \\
2.7 \\
4.4 \\
\cdots \cdots\end{array}$ & $\begin{array}{l}1.1 \\
1.1 \\
1.1 \\
1.1 \\
1.2 \\
1.3\end{array}$ & \begin{tabular}{r|r}
1.1 \\
1.1 \\
1.0 \\
1.0 \\
.9 \\
$\cdots \cdots$
\end{tabular} & $\begin{array}{r}.9 \\
.9 \\
.9 \\
1.0 \\
1.0 \\
1.0\end{array}$ \\
\hline
\end{tabular}

\begin{tabular}{|c|c|c|c|c|c|c|c|c|c|c|c|c|}
\hline Day. & Jan. & Feb. & Mar. & Apr. & May. & June. & July. & Aug. & Sept. & Oet. & Nor. & Dec. \\
\hline $\begin{array}{l}\quad 190 \\
1 \ldots \ldots \\
2 \ldots \ldots \\
3 \ldots \ldots \\
4 \ldots \ldots \\
5 \ldots \ldots \\
\ldots \ldots\end{array}$ & $\begin{array}{l}1.0 \\
1.0 \\
1.0 \\
1.0 \\
1.0\end{array}$ & $\begin{array}{r}0.8 \\
.8 \\
.8 \\
.8 \\
.8\end{array}$ & $\begin{array}{r}0.9 \\
.9 \\
.9 \\
.9 \\
.9\end{array}$ & $\begin{array}{l}1.5 \\
1.4 \\
1.5 \\
1.6 \\
1.8\end{array}$ & $\begin{array}{l}7.6 \\
7.1 \\
6.4 \\
6.0 \\
5.4\end{array}$ & $\begin{array}{l}6.5 \\
5.5 \\
5.1 \\
4.3 \\
4.2\end{array}$ & $\begin{array}{l}2.0 \\
2.1 \\
2.2 \\
2.0 \\
1.9\end{array}$ & $\begin{array}{l}1.5 \\
1.6 \\
1.7 \\
1.8 \\
1.9\end{array}$ & $\begin{array}{l}1.1 \\
1.0 \\
1.1 \\
1.0 \\
1.1\end{array}$ & $\begin{array}{r}1.3 \\
1.2 \\
1.1 \\
.7 \\
1.1\end{array}$ & $\begin{array}{l}1.3 \\
1.4 \\
1.4 \\
1.3 \\
1.3\end{array}$ & $\begin{array}{l}1.3 \\
1.3 \\
1.3 \\
1.3 \\
1.3\end{array}$ \\
\hline $\begin{array}{r}6 . \\
7 . \\
8 . \\
9 . \\
10 .\end{array}$ & $\begin{array}{l}1.0 \\
1.0 \\
1.0 \\
1.0 \\
.9\end{array}$ & $\begin{array}{l}.8 \\
.7 \\
.6 \\
.5 \\
.4\end{array}$ & $\begin{array}{l}.9 \\
.9 \\
.8 \\
.7 \\
.7\end{array}$ & $\begin{array}{l}2.0 \\
2.9 \\
3.5 \\
3.0 \\
3.4\end{array}$ & $\begin{array}{l}5.0 \\
4.7 \\
4.3\end{array}$ & 34 & 2.0 & $\begin{array}{l}1.3 \\
1.4\end{array}$ & $\begin{array}{r}.7 \\
.6 \\
1.0 \\
1.1 \\
1.3\end{array}$ & $\begin{array}{r}1.0 \\
1.1 \\
1.0 \\
.9 \\
1.0\end{array}$ & 1.3 & $\begin{array}{l}1.3 \\
1.3 \\
1.3 \\
1.3 \\
1.3\end{array}$ \\
\hline . & $\begin{array}{l}.9 \\
.9 \\
.8 \\
.8 \\
.8\end{array}$ & $\begin{array}{r}.4 \\
.5 \\
.7 \\
1.1 \\
1.1\end{array}$ & $\begin{array}{l}.7 \\
.7 \\
.7 \\
.7 \\
.7\end{array}$ & $\begin{array}{l}3.8 \\
3.9 \\
4.3 \\
4.4 \\
4.5\end{array}$ & 3.9 & & $\begin{array}{l}1.7 \\
1 . \\
1 .\end{array}$ & $\begin{array}{l}1.3 \\
1.4\end{array}$ & $\begin{array}{r}1.2 \\
1.1 \\
.8 \\
.9 \\
.8\end{array}$ & $\begin{array}{r}.8 \\
1.2 \\
1.1 \\
1.0 \\
1.1\end{array}$ & $\begin{array}{l}1.1 \\
1.0 \\
9\end{array}$ & $\begin{array}{l}1.2 \\
1.2 \\
1.2 \\
1.2 \\
1.2\end{array}$ \\
\hline $0 \ldots \ldots$ & $\begin{array}{l}.8 \\
.7 \\
.7 \\
.8 \\
.8\end{array}$ & $\begin{array}{r}1.0 \\
1.0 \\
.9 \\
.9 \\
.8\end{array}$ & $\begin{array}{l}.8 \\
.8 \\
.8 \\
.8 \\
.9\end{array}$ & $\begin{array}{l}5.6 \\
5.5 \\
5.6 \\
5.7 \\
6.0\end{array}$ & $\begin{array}{l}4.6 \\
6.3\end{array}$ & 2.7 & $\begin{array}{l}1.3 \\
1.4 \\
1.7\end{array}$ & $\begin{array}{l}1.3 \\
1.4 \\
1.3\end{array}$ & $\begin{array}{r}.9 \\
.7 \\
.8 \\
1.0 \\
.7\end{array}$ & $\begin{array}{r}1.0 \\
.9 \\
.7 \\
.9 \\
1.0\end{array}$ & $\begin{array}{r}.9 \\
.9 \\
.9\end{array}$ & $\begin{array}{l}1 . \\
1 . \\
1 .\end{array}$ \\
\hline .... & $\begin{array}{l}.8 \\
.8 \\
.8 \\
.8 \\
.8\end{array}$ & $\begin{array}{l}.7 \\
.7 \\
.8 \\
.9 \\
.9\end{array}$ & $\begin{array}{l}1.0 \\
1.2 \\
1.4 \\
1.7 \\
1.8\end{array}$ & $\begin{array}{l}5.9 \\
5.7 \\
5.3 \\
5.0 \\
5.3\end{array}$ & $\begin{array}{l}7.6 \\
7.7 \\
7.8\end{array}$ & $\begin{array}{l}2.7 \\
4.0\end{array}$ & $\begin{array}{l}1.5 \\
1.4 \\
1.9\end{array}$ & $\begin{array}{l}1.3 \\
1.0\end{array}$ & $\begin{array}{r}1.0 \\
.9 \\
1.0 \\
.9 \\
1.0\end{array}$ & $\begin{array}{r}.9 \\
1.0 \\
1.1 \\
1.2 \\
1.1\end{array}$ & $\begin{array}{l}.9 \\
.8 \\
.8 \\
.8 \\
.9\end{array}$ & $\begin{array}{l}1 . \\
1 . \\
1 . \\
1 .\end{array}$ \\
\hline 29. & $\begin{array}{l}.8 \\
.8 \\
.8 \\
.8 \\
.8 \\
.8\end{array}$ & $\begin{array}{r}.9 \\
.9 \\
.9 \\
.9 \\
\cdots \\
\cdots\end{array}$ & $\begin{array}{l}1.7 \\
1.7 \\
1.6 \\
1.5 \\
1.5 \\
1.4\end{array}$ & $\begin{array}{l}6.4 \\
7.2 \\
8.3 \\
8.9 \\
8.4\end{array}$ & $\begin{array}{l}7.9 \\
8.0 \\
7.7 \\
7.0 \\
6.3 \\
6.4\end{array}$ & $\begin{array}{c}2.9 \\
3.0 \\
2.1 \\
2.3 \\
1.9 \\
\cdots \cdots\end{array}$ & $\begin{array}{l}1.5 \\
1.4 \\
1.5 \\
1.4 \\
2.1 \\
2.4\end{array}$ & $\begin{array}{l}1.1 \\
1.2 \\
1.1 \\
1.0 \\
1.1 \\
1.0\end{array}$ & $\begin{array}{r}.9 \\
.8 \\
1.2 \\
1.1 \\
1.0\end{array}$ & $\begin{array}{l}1.2 \\
1.3 \\
1.2 \\
1.3 \\
1.4 \\
1.4\end{array}$ & $\begin{array}{l}1.3 \\
1.3\end{array}$ & $\begin{array}{l}1 . \\
1 .\end{array}$ \\
\hline
\end{tabular}

a River frozen January 1 to March 16, and from about December 6 to $31,1907$.

$b$ Riverf rozen Jamuary 1 to March 20 and during December, 1908. Ręadings during the frozen periods are to water surface. 
Rating tables for Chippewa River at Chippewa Falls, Wis.

1899 TO 1908.

\begin{tabular}{|c|c|c|c|c|c|c|c|}
\hline $\begin{array}{l}\text { Gage } \\
\text { height. }\end{array}$ & $\begin{array}{l}\text { Dis- } \\
\text { charge. }\end{array}$ & $\begin{array}{c}\text { Gage } \\
\text { height. }\end{array}$ & $\begin{array}{c}\text { Dis- } \\
\text { charge. }\end{array}$ & $\begin{array}{l}\text { Crage } \\
\text { leight. }\end{array}$ & $\begin{array}{c}\text { Dis- } \\
\text { charge. }\end{array}$ & $\begin{array}{c}\text { Gage } \\
\text { height. }\end{array}$ & $\begin{array}{c}\text { Dis- } \\
\text { charge. }\end{array}$ \\
\hline Fect. & Scc. $-f t$. & Feet. & Sec.ft. & Fett. & Sec.fft. & Feet. & Sec. $f t$. \\
\hline 0.00 & 500 & 1. 50 & 3,110 & 3.00 & 6,850 & 6.00 & 16,550 \\
\hline .10 & 600 & 1.60 & 3,340 & 3.20 & 7,420 & 7.00 & 20,350 \\
\hline .20 & 710 & 1.70 & 3,570 & 3.40 & 8,000 & 8.00 & 24,250 \\
\hline .30 & 840 & 1. 80 & 3,800 & 3.60 & 8,600 & 9.00 & 28,250 \\
\hline .40 & 980 & 1.90 & 4,040 & 3.80 & 9,200 & 10.00 & 32,300 \\
\hline .50 & 1,130 & 2.00 & 4,280 & 4.00 & 9,800 & 11.00 & 36,400 \\
\hline .60 & 1,290 & 2.10 & 4,520 & 4. 20 & 10,420 & 12.00 & 40,600 \\
\hline .70 & 1,460 & 2.20 & 4,760 & 4. 40 & 11,050 & 13.00 & 44.800 \\
\hline .80 & 1,640 & 2.30 & 5,010 & 4. 60 & 11,690 & 14.00 & 49,100 \\
\hline .90 & 1,830 & 2.40 & 5,260 & 4. 80 & 12.340 & 15.00 & 53,400 \\
\hline 1.00 & 2,030 & 2.50 & 5,510 & 5.00 & 13,000 & 16.00 & 57,800 \\
\hline 1.10 & 2,240 & 2. 60 & 5,770 & 5.20 & 13,680 & 17.00 & 62,200 \\
\hline 1.20 & 2450 & 2.70 & 6,030 & 5. 40 & 14,380 & 18.00 & 66,700 \\
\hline 1.30 & 2,670 & 2.80 & 6,300 & 5. 60 & 15,090 & & \\
\hline 1.40 & 2,890 & 2.90 & 6,570 & 5.80 & 15,810 & & \\
\hline
\end{tabular}

Note.-The above table is not applicable for ice or obstructed-channel conditions. It is based on 16 dis.harge measurements made during 1906 to 1908 and is well defined hetween gage heights 1.0 foot and 11 feet. Comparisons with the discharge at Eau Claire indicate that this table is applicable to Chippewa Falls gage heights with equal accuracy for all years 1903 to 1908 (except 1905) and hence it is assumed to apply correctly for 1899 to 1902 . (See fig. 1.)

JANUARY 1, 1908, TO MARCH 20, 1908.

\begin{tabular}{|c|r||r|r|}
\hline $\begin{array}{c}\text { Gage } \\
\text { height. }\end{array}$ & $\begin{array}{c}\text { Dis- } \\
\text { charge. }\end{array}$ & $\begin{array}{c}\text { Gage } \\
\text { height. }\end{array}$ & $\begin{array}{c}\text { Dis- } \\
\text { charge. }\end{array}$ \\
\hline Fect. & Sec.-ft. & Feet. & Sec.ft. \\
0.40 & 900 & .80 & 1,300 \\
.50 & 1,000 & .90 & 1,400 \\
.60 & 1,100 & 1.00 & 1,500 \\
.70 & 1,200 & 1.10 & 1,600 \\
\hline
\end{tabular}

Note.-The above table is applicalle only for ice conditions from January 1 to March 20,1908 . It is based on two discharge measurements made during 1908 and is approximate only.

Monthly discharge of Chippewa River at Chippewa Falls, Wis., for 1899 to 1908.

[Drainage area, 5,300 square miles.]

\begin{tabular}{|c|c|c|c|c|c|c|}
\hline \multirow{2}{*}{ Month. } & \multicolumn{4}{|c|}{ Discharge in second-feet. } & \multirow{2}{*}{$\begin{array}{c}\text { Run-off } \\
\text { (depth in } \\
\text { inches on } \\
\text { drainage } \\
\text { area). }\end{array}$} & \multirow{2}{*}{$\begin{array}{l}\text { Accu- } \\
\text { racy. }\end{array}$} \\
\hline & Maximum. & Minimum. & Mean. & $\begin{array}{c}\text { Per } \\
\text { square } \\
\text { mile. }\end{array}$ & & \\
\hline $1899 . a$ & & & & & & \\
\hline April $10-30 \ldots \ldots \ldots \ldots \ldots \ldots \ldots . . . . . .$. & 26,200 & 5,110 & 12,700 & 2. 40 & 1.87 & A. \\
\hline 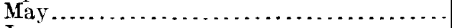 & 27,200 & 3,870 & 13,100 & 2.47 & 2.85 & A. \\
\hline June . . . . . . . . . . . . . . . & 20,400 & 3,870 & 10,600 & 2.00 & 2.23 & A. \\
\hline$\ldots \ldots \ldots \ldots \ldots \ldots$ & 15,500 & 120 & 3,910 & .738 & .85 & A. \\
\hline lugust.......... & 18,400 & 1,550 & 3,540 & .668 & .77 & A. \\
\hline September... & 10,600 & 1,800 & 2,710 & .511 & .57 & 1. \\
\hline October..... & 20,800 & 1,130 & 4,700 & .887 & 1. 02 & A. \\
\hline November.... & 5,950 & 2,560 & 3,480 & .657 & .73 & A. \\
\hline $1900 . a$ & & & & & & \\
\hline$\ldots \ldots \ldots \ldots \ldots \ldots \ldots \ldots \ldots$ & 40,400 & 4,690 & 16,000 & 3.02 & 2.70 & A. \\
\hline $\begin{array}{l}\text { May....... } \\
\text { June...... }\end{array}$ & $\begin{array}{l}17,500 \\
10,700\end{array}$ & $\begin{array}{l}2,560 \\
1,550\end{array}$ & $\begin{array}{l}7,180 \\
2,610\end{array}$ & $\begin{array}{l}1.35 \\
.492\end{array}$ & $\begin{array}{r}1.56 \\
.55\end{array}$ & A. \\
\hline July..... & 23,300 & 2,120 & 6,810 & 1. 28 & 1.48 & A. \\
\hline August... & 29,800 & 3,110 & 9,800 & 1.85 & 2.13 & A. \\
\hline September & 44,800 & 5,510 & 17,700 & 3.34 & 3.73 & A. \\
\hline October. & 45,500 & 4,280 & 15,600 & 2.94 & 3.39 & A. \\
\hline November 1 & 31,300 & 4,880 & 11,500 & 2.17 & 1.94 & A, \\
\hline
\end{tabular}

$a$ Discharge estimated for days when the gage was not read.

$22110-$ IRR $245-10-6$ 
Monthly discharge of Chippewa River at Chippewa Falls, Wis., for 1899 to 1908-Con.

\begin{tabular}{|c|c|c|c|c|c|c|}
\hline \multirow[b]{2}{*}{ Month. } & \multicolumn{4}{|c|}{ Discharge in second-feet. } & \multirow{2}{*}{$\begin{array}{c}\text { Run-off } \\
\text { (depth in } \\
\text { inches in } \\
\text { drainage } \\
\text { area). }\end{array}$} & \multirow[b]{2}{*}{$\begin{array}{l}\text { Accu- } \\
\text { racy. }\end{array}$} \\
\hline & Maximum. & Minimum. & Mean. & $\begin{array}{c}\text { Per } \\
\text { square } \\
\text { mile. }\end{array}$ & & \\
\hline 1901.a & & & & & & \\
\hline 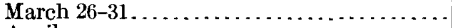 & 9,800 & 7,950 & 8,870 & 1. 67 & .37 & A. \\
\hline April.............. & 21,300 & 5,510 & 14,800 & 2.79 & 3. 11 & A. \\
\hline$\ldots \ldots \ldots \ldots \ldots$ & 17,300 & 3,110 & 6,480 & 1. 22 & 1.41 & A. \\
\hline$\ldots \ldots \ldots \ldots \ldots \ldots$ & 16,600 & 2,030 & 5,210 & .983 & 1. 10 & A. \\
\hline$\ldots \ldots \ldots \ldots \ldots \ldots$ & 15,000 & 1,700 & 7,900 & 1.49 & 1.72 & A. \\
\hline (n... & 18,400 & 2,030 & 5,490 & 1. 03 & 1. 19 & A. \\
\hline 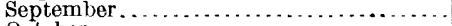 & 6,850 & 2,030 & 3,030 & .572 & .64 & A. \\
\hline$\ldots \ldots \ldots \ldots \ldots \ldots \ldots$ & 16,600 & 1,130 & 5,260 & .992 & 1. 14 & A. \\
\hline November $1-19 \ldots \ldots \ldots \ldots \ldots \ldots \ldots \ldots \ldots$ & 5,510 & 2,030 & 3,710 & .700 & .49 & A. \\
\hline $1902 . a$ & & & & & & \\
\hline & 8,060 & 3,680 & 6,330 & 1.19 & $\therefore 97$ & A. \\
\hline & 23,300 & 2,030 & 6,830 & 1. 29 & 1.44 & A. \\
\hline $\begin{array}{l}\text { May } \\
\text { June }{ }_{1} \ldots{ }_{1}\end{array}$ & 17,000 & 3,870 & 9,470 & 1.79 & 2.06 & A. \\
\hline & 23,300 & 2,000 & 6,960 & 1. 31 & 1. 46 & A. \\
\hline ( & $\begin{array}{r}15,000 \\
8,420\end{array}$ & 1,700 & 5,160 & .974 & 1. 12 & A. \\
\hline ( & $\begin{array}{l}8,420 \\
8,780\end{array}$ & $\begin{array}{l}1,410 \\
1,700\end{array}$ & $\begin{array}{l}2,250 \\
2,300\end{array}$ & $\begin{array}{r}+420 \\
434\end{array}$ & $\cdot 49$ & A. \\
\hline$\ldots \ldots \ldots \ldots \ldots$ & 6,630 & 1,700 & 2,520 & $\begin{array}{l}.404 \\
.475\end{array}$ &. .48 & A. \\
\hline$\ldots \ldots \ldots \ldots \ldots \ldots$ & 28,200 & 4,000 & 9,890 & 1.87 & 2.09 & A. \\
\hline December $1-9 \ldots \ldots \ldots \ldots \ldots \ldots \ldots \ldots$ & 3,870 & 2,030 & 2,730 & .515 & .17 & A. \\
\hline $1903 . a$ & & & & & & \\
\hline March $18-31 \ldots \ldots \ldots$ & 32,800 & 8,300 & 17,100 & 3.23 & 1.68 & A. \\
\hline 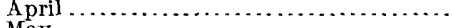 & 26,600 & 6,630 & 10,200 & 1.92 & 2.14 & A. \\
\hline 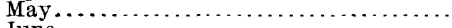 & 41,900 & 13,700 & 22,700 & 4. 28 & 4. 93 & A. \\
\hline 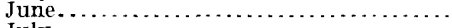 & 25,600 & 1,130 & 7,040 & 1. 33 & 1. 48 & A. \\
\hline July .............. & 34,700 & 2,030 & 12,400 & 2.34 & 2.70 & A. \\
\hline 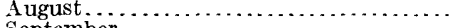 & 22,600 & 3,000 & 6,900 & 1.30 & 1.50 & A. \\
\hline 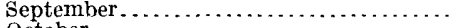 & 45,900 & 4,280 & 16,400 & 3.09 & 3.45 & A. \\
\hline 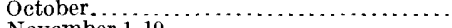 & 24,200 & 4,280 & 11,700 & 2.21 & 2.55 & A. \\
\hline November $1-19 \ldots \ldots \ldots \ldots \ldots \ldots \ldots \ldots \ldots$ & 4,280 & 2,560 & 3,330 & .628 & .44 & A. \\
\hline $1904 . a$ & & & & & & \\
\hline April $6-30, \ldots \ldots \ldots \ldots \ldots \ldots \ldots \ldots \ldots \ldots \ldots \ldots \ldots \ldots$ & 20,500 & 8,540 & 12,900 & 2.43 & 2.26 & A. \\
\hline 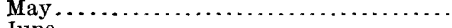 & 33,300 & 6,850 & 15,100 & 2.85 & 3.29 & A. \\
\hline June $\ldots \ldots \ldots \ldots \ldots \ldots \ldots \ldots \ldots \ldots \ldots \ldots$ & 21,400 & 4,280 & 11,000 & 2.08 & 2,32 & A. \\
\hline 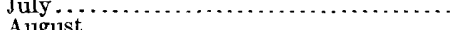 & 20,400 & 3,000 & 7,220 & 1. 36 & 1. 57 & A. \\
\hline 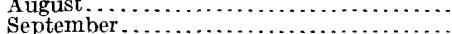 & 11,500 & 1,130 & 2,840 & .536 & .62 & A. \\
\hline 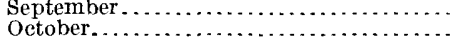 & 23,300 & 1,130 & 7,370 & 1. 39 & 1.55 & A. \\
\hline 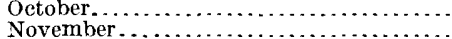 & 39,600 & 3,110 & 14,600 & 2.75 & 3.17 & A. \\
\hline November.............................. & 13,900 & 2,560 & 4,690 & .885 & .99 & A. \\
\hline 1905.a & & & & & & \\
\hline 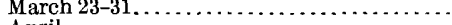 & 30,200 & 4,280 & 14,900 & 2.81 & .94 & A. \\
\hline April ................ & 25,400 & 2,450 & 9,720 & 1.83 & 2.04 & A. \\
\hline 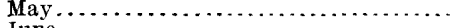 & 26,600 & 4,760 & 11,800 & 2.23 & 2.57 & A. \\
\hline 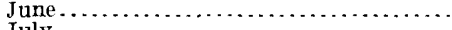 & 64,400 & 4,760 & 21,600 & 4.08 & 4. 55 & A. \\
\hline 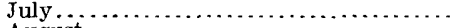 & 27,000 & 3,110 & 9,530 & 1.80 & 2.08 & A. \\
\hline$\ldots \ldots \ldots \ldots \ldots \ldots \ldots \ldots$ & 8,600 & 2,450 & 4,780 & .902 & 1.04 & A. \\
\hline$\ldots \ldots \ldots \ldots \ldots \ldots \ldots$ & 22,300 & 3,340 & 7,650 & 1.44 & 1. 61 & A. \\
\hline October....... & 14,700 & 2,560 & 7,890 & 1. 49 & 1.72 & A. \\
\hline November . ...... & 6,160 & 3,680 & 4,870 & .919 & 1.03 & A. \\
\hline December 1-21.. & 5,510 & 4,280 & 4.630 & .874 & .68 & A. \\
\hline $1906 . a$ & & & & & & \\
\hline April ..... & 38,500 & 10,300 & 23,400 & 4.42 & 4.93 & A. \\
\hline May .......... & 22,000 & 3,110 & 11,400 & 2.15 & 2.48 & A. \\
\hline 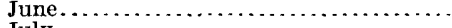 & 24,100 & 2,600 & 8,660 & 1. 63 & 1.82 & A. \\
\hline July $\ldots \ldots \ldots \ldots \ldots$ & 13,000 & 1,700 & 4,660 & .879 & 1.01 & A. \\
\hline August ........... & 16,800 & 1,870 & 5,820 & 1.10 & 1.27 & A. \\
\hline September. & 19,400 & 1,700 & 5,930 & 1.12 & 1.25 & A. \\
\hline October.......... & 13,300 & 2,030 & 5,780 & 1.09 & 1. 26 & A. \\
\hline November........ & 9,290 & 4,280 & 7,050 & 1.33 & 1.48 & A. \\
\hline March 17-31 1907 & & & & & & \\
\hline March $17-31 \ldots \ldots \ldots \ldots \ldots \ldots$ & 36,400 & 3,570 & 15,200 & 2.87 & 1. 60 & A. \\
\hline April ......... & 30,200 & 6,300 & 13,900 & 2.62 & 2.92 & A. \\
\hline 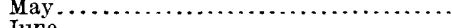 & 18,800 & 8,000 & 11,400 & 2.15 & 2. 48 & A. \\
\hline June...... & 9,800 & 4,520 & 6,280 & 1. 18 & 1.32 & A. \\
\hline July ................. & 8,300 & 2,030 & 3,970 & .749 & .86 & A. \\
\hline August .......... & 2,670 & 1,640 & 2,230 & .421 & +49 & A. \\
\hline September.... & 32,300 & 1,290 & 8,170 & 1. 54 & 1.72 & A. \\
\hline October... & 6,300 & 2,240 & 3,240 & .611 & .70 & A. \\
\hline November & 3,110 & 1,830 & 2,630 & .496 & .55 & A. \\
\hline December $b$ & & & 1,600 & .302 & .35 & C. \\
\hline
\end{tabular}

a Discharge estimated for days when the gage was not read.

$b$ Discharge December, 1907 , estimated on the basis of one measurement made under ice conditions during the month, 
Monthly discharge of Chippewa River at Chippewa Falls, Wis., for 1899 to 1908-Con.

\begin{tabular}{|c|c|c|c|c|c|c|}
\hline \multirow[b]{2}{*}{ Mouth. } & \multicolumn{4}{|c|}{ Discharge in second-feet. } & \multirow{2}{*}{$\begin{array}{l}\text { Run-off } \\
\text { (depth in } \\
\text { inches on } \\
\text { drainage } \\
\text { area). }\end{array}$} & \multirow[b]{2}{*}{$\begin{array}{l}\text { Accu- } \\
\text { racy. }\end{array}$} \\
\hline & Maxinıuml. & Mininıum. & Mean. & $\begin{array}{c}\text { Per } \\
\text { square } \\
\text { mile. }\end{array}$ & & \\
\hline 1908. & & & & & & \\
\hline January . . . . . . . . . . & 1,500 & 1,200 & 1,360 & .257 & .30 & C. \\
\hline February.......... & 1,720 & 900 & 1,300 & .245 & .26 & C. \\
\hline March.......... & 3,800 & 1,200 & 1,950 & .368 & .42 & B. \\
\hline$\ldots \ldots \ldots \ldots$ & 27,800 & 2,890 & 12,300 & 2.32 & 2.59 & A. \\
\hline May............ & 24,200 & 7,710 & 15,700 & 2.96 & 3.41 & A. \\
\hline June.......... & 18,400 & 4,040 & 8,880 & 1. 68 & 1.87 & A. \\
\hline July ...... & 5,260 & 2,670 & 3,670 & .692 & .80 & $\Lambda$. \\
\hline August ....... & 4,040 & 2,030 & 2,730 & .515 & .59 & A. \\
\hline September.... & 2,670 & 1,290 & 1,950 & .368 & .41 & A. \\
\hline October........ & 2,890 & 1,460 & 2,190 & .413 & .48 & A. \\
\hline November...... & 2890 & 1,640 & 2,200 & .415 & .46 & A. \\
\hline December $a . .$. . & $\ldots \ldots \ldots$ & $\ldots \ldots \ldots$. & 1,500 & .283 & .33 & D. \\
\hline The year. & 27,800 & 900 & 4,640 & .876 & 11.92 & \\
\hline
\end{tabular}

$a$ Discharge December, 1908, based on discharge at Eau Claire.

CHIPPEWA RIVER NEAR EAU ClaIRE, WIS.

This station, which is located at the highway bridge at Shawtown, about 2 miles below Eau Claire, Wis., was established November 13, 1902, to obtain data for water-power and storage problems.

Eau Claire River enters from the east about 3 miles above the station. Winter conditions are severe in this vicinity. Ice forms to a thickness of 1 to 2 feet, and greatly modifies the relations between discharge and gage heights. The normal flow of the stream is very materially affected by the power plants at Eau Claire and Chippewa Falls, and by the holding and releasing of storage water for logging.

Except as noted the records are reliable and accurate, and the estimates of the flow should be good. The datum of the gage has remained unchanged.

Information in regard to this station prior to 1908 is contained in Bulletin XX of the Wisconsin Geological and Natural History Survey, entitled "Water powers of Wisconsin," by Leonard S. Smith.

Discharge measurements of Chippewa River near Eau Claire, Wis., in 1907 and 1908.

\begin{tabular}{|c|c|c|c|c|c|}
\hline Date. & Hydrographer. & width. & $\begin{array}{l}\text { Area of } \\
\text { section. }\end{array}$ & $\begin{array}{c}\text { Gage } \\
\text { height. }\end{array}$ & $\begin{array}{c}\text { Dis- } \\
\text { charge. }\end{array}$ \\
\hline $\begin{array}{r}1907 . \\
\text { A pril } 2 . . .\end{array}$ & A. H. Horton. & $\begin{array}{r}\text { Feet. } \\
450\end{array}$ & $\begin{array}{r}S g . j t . \\
5,670\end{array}$ & $\begin{array}{l}\text { Feet. } \\
11.78\end{array}$ & $\begin{array}{l}\text { Sec.-ft. } \\
26,700\end{array}$ \\
\hline May $5 \ldots .$. & .... do ........ & 364 & 3,880 & 7.50 & 10,900 \\
\hline June 15 . & G. A. Gray. & 351 & 3,430 & 6. 06 & 6,910 \\
\hline July 15. & ..... do...... & 334 & 2,970 & 5.37 & 4,640 \\
\hline August 16. & .....do.. & 167 & 1,900 & 4.21 & 2.420 \\
\hline September $19 .$. & ......do. & 375 & 4,050 & 8.00 & 12,100 \\
\hline September 22. & .. do. & 466 & 6,380 & 12.92 & 27,900 \\
\hline September 27 . & do. & 371 & 4,210 & 7.95 & 11.900 \\
\hline October 21 & do. & 197 & 2,340 & 4.77 & 3,410 \\
\hline Do. & …do. do. & 197 & 2,290 & 4.87 & 3,520 \\
\hline November $16 \ldots$ & ...... do & 222 & 2,230 & 4. 60 & 3,340 \\
\hline December $19 a$. & .....do. & 207 & 2,180 & 3.90 & 2,470 \\
\hline $\begin{array}{c}1908 . \\
\text { January } 22 b .\end{array}$ & G. A. Gray. & & & & \\
\hline $\begin{array}{l}\text { January } 220 \ldots \\
\text { February } 15 \\
\end{array}$ & ... do..... & 330 & $\begin{array}{l}1,080 \\
2,670\end{array}$ & $\begin{array}{l}4.00 \\
4.65\end{array}$ & $\begin{array}{l}2,190 \\
2,690\end{array}$ \\
\hline September $11 .$. & .....do. & 317 & 2,670 & 3.90 & 1,960 \\
\hline
\end{tabular}

$a$ Ice conditions and discharge partly estimated.

$b$ Ice 30 to 35 feet wide at both shores.

c Ice measurement; ice 0.8 foot thick, 
Daily gage height, in feet, of Chippewa River near Eau Claire, Wis., for $190 \%$ and 1908.

[Jos. E. Kimpton, observer.]

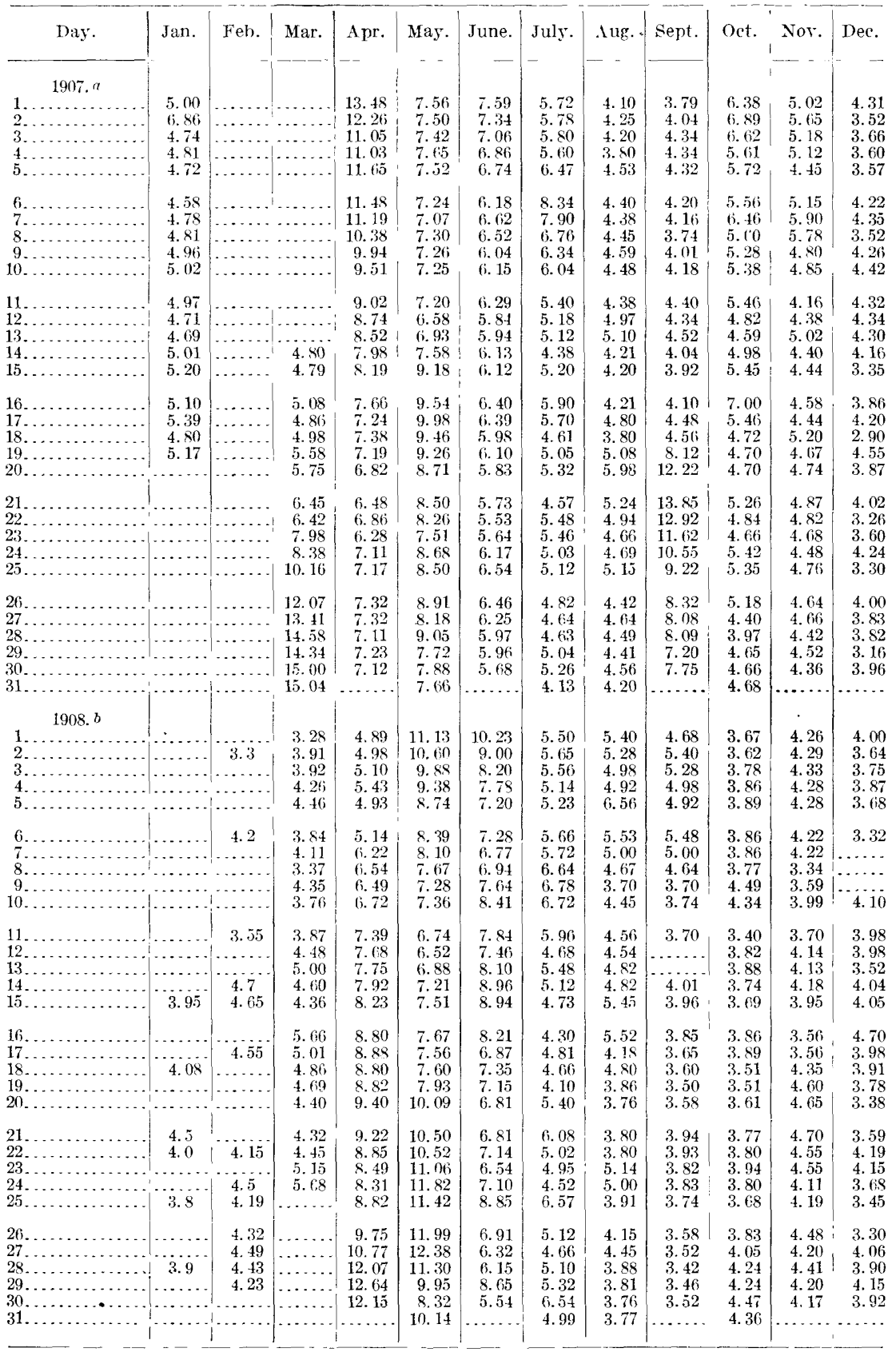

$a$ Frozen January 20 to March 13, 1907. Ice conditions during part of December, 1907.

$b$ Stream frozen January 1 to February 24 , December 7 to 9 , and December $31,1908$. 
Rating table for Chippewa River near Eau Claire, Wis., for 1906 to 1908.

\begin{tabular}{|c|c|c|c|c|c|c|c|}
\hline $\begin{array}{c}\text { Gage } \\
\text { height. }\end{array}$ & $\begin{array}{c}\text { Dis- } \\
\text { charge. }\end{array}$ & $\| \begin{array}{c}\text { Gage } \\
\text { height. }\end{array}$ & $\begin{array}{c}\text { Dis- } \\
\text { charge. }\end{array}$ & $\begin{array}{c}\text { Gage } \\
\text { height. }\end{array}$ & $\begin{array}{c}\text { Dis- } \\
\text { charge. }\end{array}$ & $\begin{array}{c}\text { Gage } \\
\text { height. }\end{array}$ & $\begin{array}{c}\text { Dis- } \\
\text { charge. }\end{array}$ \\
\hline Feet. & Sec. $f t$. & Fect. & Sec.-fi. & Fect. & Sec.fft. & Feet. & Sec.-ft. \\
\hline 3.00 & 310 & $4.30^{\circ}$ & 2,540 & 5.60 & 5,500 & $7.80^{\circ}$ & 11,730 \\
\hline 3.10 & 440 & 4.40 & 2,740 & 5. 70 & 5,760 & 8.00 & 12,350 \\
\hline 3.20 & 600 & 4. 50 & 2,950 & 5.80 & 6,020 & 8.20 & 12,970 \\
\hline 3.30 & 750 & 4. 60 & 3,100 & 5.90 & 6.280 & 8.40 & 13,600 \\
\hline 3.40 & 900 & 4. 70 & 3,380 & 6.00 & 6.550 & 8. 60 & 14,240 \\
\hline 3.50 & 1,050 & 4. 80 & 3,600 & 6.20 & 7.090 & 8.80 & 14,890 \\
\hline 3.60 & 1,210 & 4.90 & 3.820 & 6.40 & 7,$6 ; 0$ & 9.00 & 15,550 \\
\hline 3.70 & 1,390 & 5.00 & 4,050 & 6.60 & 8,200 & 10.00 & 18,950 \\
\hline 3.80 & 1,570 & 5. 10 & 4,280 & 6.80 & 8.770 & 11.00 & 22,550 \\
\hline 3.90 & 1,760 & 5. 20 & 4.520 & 7.00 & 9.350 & 12.00 & 20.350 \\
\hline 4.00 & 1,950 & 5.30 & 4,760 & 7.20 & 9,930 & 13.00 & 30,350 \\
\hline 4. 10 & 2,140 & 5.40 & 5,000 & 7.40 & 10.530 & 14.00 & 34.500 \\
\hline 4.20 & 2,340 & 5.50 & 5,250 & 7. 60 & 11,130 & 15.00 & 38,750 \\
\hline
\end{tabular}

NoтE.- The above table is not applicable for ice or obstructed-channel conditions. It is based on discharge measurements made during 1902 to 1908 , and is well defined between gage heights 4 feet and 15 feet.

Monthly discharge of Chippeva River near Eau Claire, Wis., for 1907 and 1908.

[Drainage area, 6,740 square miles ]

\begin{tabular}{|c|c|c|c|c|c|c|}
\hline \multirow[b]{2}{*}{ Month. } & \multicolumn{4}{|c|}{ Discharge in second-feet. } & \multirow{2}{*}{$\begin{array}{l}\text { Run-off } \\
\text { (depth in } \\
\text { inches } \\
\text { on drain- } \\
\text { age area). }\end{array}$} & \multirow[b]{2}{*}{$\begin{array}{l}\text { Acci- } \\
\text { racy. }\end{array}$} \\
\hline & Maximum. & Minimum. & Mean. & $\begin{array}{c}\text { Per } \\
\text { square } \\
\text { mile. }\end{array}$ & & \\
\hline $1907 . a$ & & & & & & \\
\hline January $1-19 . \ldots \ldots \ldots \ldots \ldots \ldots \ldots \ldots$ & 8,940 & 3,120 & 4,130 & 0.613 & 0.43 & A. \\
\hline March $14-31 \ldots \ldots \ldots \ldots \ldots \ldots \ldots \ldots$ & 38,900 & 3,580 & 16,700 & 2.48 & 1. 66 & A. \\
\hline 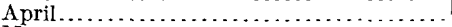 & 32,300 & 7,310 & 15,100 & 2.24 & 2.50 & A. \\
\hline May & 18,900 & 8,140 & 12,500 & 1.85 & 2.13 & A. \\
\hline 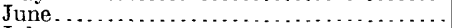 & 11,100 & 5,320 & 7,310 & 1.08 & 1. 20 & A. \\
\hline July & 13,400 & 2,200 & 5,400 & .801 & .92 & A. \\
\hline August . . . . . . . . . & 6,500 & 1,570 & 3,310 & 491 & .57 & A. \\
\hline Septernber....... & 33,900 & 1,460 & 8,930 & 1.32 & 1.47 & A. \\
\hline (................... & 9,350 & 1,890 & 4,870 & .723 & .83 & A. \\
\hline$\ldots \ldots \ldots$ & 6,280 & 2,260 & 3,640 & .540 & .61 & A. \\
\hline 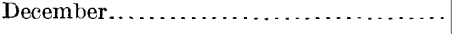 & 3,060 & 190 & 1,770 & .265 & .30 & C. \\
\hline $1908 . b$ & & & & & & \\
\hline January .................. . & & +2 & 2,100 & .312 & .36 & D. \\
\hline February ......... & & & 2,200 & .326 & .35 & D. \\
\hline March.......... & 5,710 & 720 & 3,260 & .484 & .56 & A. \\
\hline April........... & 28,900 & 3,800 & 12,900 & 1.91 & 2.13 & 1. \\
\hline$\ldots \ldots \ldots \ldots \ldots \ldots$ & 27,800 & 7,980 & 16,400 & 2.43 & 2.80 & A. \\
\hline 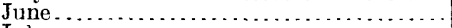 & 19,800 & 5,350 & 11,100 & 1.65 & 1. 84 & 1. \\
\hline July ........... & 8,710 & 2,140 & 5,040 & .748 & .86 & A. \\
\hline August.... & 8,090 & 1,390 & 3,230 & .479 & .55 & A. \\
\hline September. & 5,200 & 930 & 2,160 & .320 & .36 & B. \\
\hline Detober......... & 2,930 & 900 & 1,730 & .257 & .30 & B. \\
\hline November....... & 3,380 & 810 & 2,310 & .343 & .38 & B. \\
\hline December........ & 3,380 & 750 & 1,680 & .249 & .29 & C. \\
\hline The year... & 28,900 & 720 & 5,340 & .792 & 10.78 & \\
\hline
\end{tabular}

a Open-channel rating applied for December, 1907; discharge probably somewhat too high.

$b$ Discharge January 1 to February 24,1908 , based on 1 wo measturements made under ice conditions and the discharge at Chippewa Falls. Open-channel rating applied December, 1908; discharge probably somewhat too high.

RED CEDAR RIVER AT MENOMINEE, WIS.

This station, which is located at a highway bridge west of Menominee, about 200 rods from the Chicago and Northwestern Railroad depot, was established June 17, 1907, to obtain data for water power and storage problems. It was discontinued September 17, 1908. 
No important tributaries enter Red Cedar River in the immediate vicinity of this station. A power plant with large reservoir storage capacity a short distance above the station modifies the flow and causes considerable fluctuation in the water surface at the gage.

Winter conditions are severe in this vicinity, but ice does not affect the discharge to any important extent.

The datum of the gage has remained unchanged and the records are reliable and accurate. A fairly good rating curve has been developed.

Information in regard to this station, prior to 1908 , is contained in Bulletin XX of the Wisconsin Geological and Natural History Survey, entitled "Water powers of Wisconsin," by Leonard S. Smith.

Discharge measurements of Red Cedar River at Menominee, Wis., in 1907 and 1908.

\begin{tabular}{|c|c|c|c|c|c|}
\hline Date. & ITydrographer. & Width. & $\begin{array}{l}\text { Area of } \\
\text { section. }\end{array}$ & $\begin{array}{c}\text { Gage } \\
\text { height. }\end{array}$ & $\begin{array}{c}\text { Dis- } \\
\text { charge. }\end{array}$ \\
\hline 1907. & & Feet. & $S q . f t$ & Feet. & Sec.-ft. \\
\hline June $18 \ldots$ & G. A. Gray ............ & 189 & 860 & 2.85 & 1,330 \\
\hline July $16 .$. & 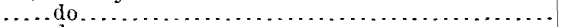 & 196 & 942 & 3.94 & 2,490 \\
\hline August 20. & 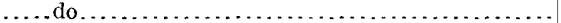 & 202 & 991 & 4.35 & 2,500 \\
\hline Septem ber $20 . .$. & 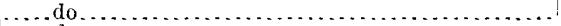 & 205 & 1,210 & 5.60 & 4,550 \\
\hline October $22 \ldots$. & $\ldots$ do $\ldots$. & 185 & 710 & 2. 43 & 782 \\
\hline Do.... & ....do............ & 181 & 656 & 2. 10 & 657 \\
\hline November 18 .. & ... do.......... & 189 & 784 & 3.00 & 1,270 \\
\hline December $21 \ldots$ & $\ldots$. do............ & 180 & 658 & 2.40 & 686 \\
\hline 1908. & & & & & \\
\hline January $25 a \ldots$ & 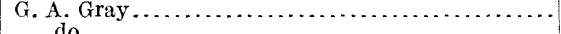 & 185 & 758 & 2.85 & 866 \\
\hline February $17 . .$. & 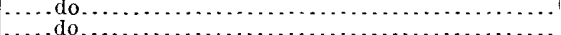 & $\begin{array}{l}190 \\
190\end{array}$ & $\begin{array}{l}848 \\
848\end{array}$ & 3. 40 & $\begin{array}{l}1,500 \\
1,520\end{array}$ \\
\hline September $9 . .$. & .... do... & 188 & $\begin{array}{l}848 \\
776\end{array}$ & $\begin{array}{l}3.42 \\
2.60\end{array}$ & 1,036 \\
\hline
\end{tabular}

$a$ Plots about 80 per cent of the open-channel rating curve; probably due to ice below the station.

Daily gage height, in feet, of Red Cedar River at Menominee, Wis., for $190 \%$ and 1908.

[H. II. Fuller, observer.]

\begin{tabular}{|c|c|c|c|c|c|c|c|c|c|c|c|c|c|c|c|}
\hline Day. & June. & July. & Aug. & Sept. & Oct. & Nov. & Dec. & Day. & June. & July. & Aug. & Sept. & Oct. & Nov. & Dec. \\
\hline & & $\begin{array}{l}3.42 \\
4.52 \\
4.62 \\
3.68 \\
3.28\end{array}$ & $\begin{array}{l}2.81 \\
2.78 \\
2.81 \\
2.72 \\
2.79\end{array}$ & \begin{tabular}{|l}
3.09 \\
2.99 \\
2.98 \\
2.88 \\
2.80
\end{tabular} & $\begin{array}{l}3.82 \\
3.48 \\
3.30 \\
3.38 \\
3.21\end{array}$ & $\begin{array}{l}2.95 \\
3.35 \\
3.10 \\
3.15 \\
2.85\end{array}$ & $\begin{array}{l}2.70 \\
2.48 \\
2.90 \\
2.52 \\
2.48\end{array}$ & $\begin{array}{l}19 . \\
17 .\end{array}$ & $\begin{array}{l}2.50 \\
2.74 \\
2.74 \\
2.78\end{array}$ & \begin{tabular}{|l|}
4.10 \\
5.96 \\
5.32 \\
4.10 \\
3.80
\end{tabular} & $\begin{array}{l}2.71 \\
2.70 \\
2.72 \\
4.42 \\
4.28\end{array}$ & $\begin{array}{l}2.88 \\
2.90 \\
2.62 \\
5.14 \\
5.66\end{array}$ & $\begin{array}{l}3.25 \\
3.64 \\
2.70 \\
2.85 \\
2.60\end{array}$ & $\begin{array}{l}2.50 \\
2.95 \\
2.95 \\
3.00 \\
2.85\end{array}$ & \\
\hline $\begin{array}{l}6 . \\
7 \\
8 . \\
8\end{array}$ & & $\begin{array}{l}4.06 \\
3.51 \\
3.18 \\
3.31 \\
3.30\end{array}$ & $\begin{array}{l}3.01 \\
2.91 \\
2.80 \\
2.75 \\
2.78\end{array}$ & $\begin{array}{l}2.70 \\
2.74 \\
2.68 \\
2.71 \\
2.76\end{array}$ & $\begin{array}{l}3.12 \\
3.08 \\
3.09 \\
3.25 \\
2.96\end{array}$ & $\begin{array}{c}2.80 \\
3.10 \\
.50 \\
1.45 \\
2.70\end{array}$ & & & & & & & & & \\
\hline & & $\begin{array}{l}3.14 \\
2.96 \\
2.89 \\
2.84 \\
3.05\end{array}$ & $\begin{array}{l}2.76 \\
2.65 \\
2.65 \\
2.68 \\
2.72\end{array}$ & $\begin{array}{l}2.69 \\
2.66 \\
2.65 \\
2.68 \\
2.64\end{array}$ & $\begin{array}{l}3.18 \\
3.08 \\
3.20 \\
3.30 \\
2.75\end{array}$ & $\begin{array}{l}2.78 \\
2.72 \\
2.68 \\
2.35 \\
2.52\end{array}$ & $\begin{array}{l}2.5 \\
2.6 \\
2.48 \\
2.38 \\
2.3\end{array}$ & & & \begin{tabular}{|l}
3.09 \\
2.99 \\
2.95 \\
2.88 \\
2.82 \\
2.88
\end{tabular} & $\begin{array}{l}2.90 \\
2.86 \\
3.00 \\
2.99 \\
3.09\end{array}$ & & $\begin{array}{l}2.74 \\
2.72 \\
2.92 \\
2.92 \\
2.15 \\
3.04\end{array}$ & & \\
\hline
\end{tabular}


Daily gage height, in feet, of Red Cedar River at Menominee, Wis., for 1907 and 1908-Continued.

\begin{tabular}{|c|c|c|c|c|c|c|c|c|c|}
\hline Day. & Jan. & Feb. & Mar. & Apr. & May. & June. & July. & Aug. & Sept. \\
\hline 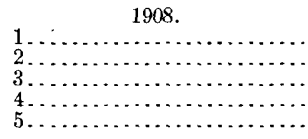 & $\begin{array}{l}2.58 \\
2.65 \\
2.82 \\
2.65 \\
2.75\end{array}$ & $\begin{array}{l}2.88 \\
2.72 \\
2.85 \\
3.00 \\
3.00\end{array}$ & $\begin{array}{l}2.50 \\
2.78 \\
2.80 \\
2.65 \\
2.65\end{array}$ & $\begin{array}{l}3.28 \\
3.60 \\
3.25 \\
3.33 \\
3.47\end{array}$ & $\begin{array}{l}4.55 \\
4.45 \\
4.25 \\
4.40 \\
4.15\end{array}$ & $\begin{array}{l}5.15 \\
3.90 \\
3.50 \\
3.35 \\
3.35\end{array}$ & $\begin{array}{l}2.15 \\
2.38 \\
2.05 \\
2.35 \\
2.20\end{array}$ & $\begin{array}{l}2.25 \\
2.30 \\
2.12 \\
2.15 \\
2.28\end{array}$ & $\begin{array}{l}2.05 \\
2.15 \\
2.10\end{array}$ \\
\hline $\begin{array}{r}6 \ldots \\
7 \ldots \\
8 \ldots \\
9 \ldots \\
10 \ldots\end{array}$ & $\begin{array}{l}2.65 \\
2.55 \\
2.68 \\
2.65 \\
2.40\end{array}$ & $\begin{array}{r}2.85 \\
2.85 \\
2.65 \\
\ldots . .\end{array}$ & $\begin{array}{l}2.65 \\
2.65 \\
2.68 \\
2.95 \\
2.75\end{array}$ & $\begin{array}{l}3.80 \\
3.55 \\
3.37 \\
3.77 \\
3.65\end{array}$ & $\begin{array}{l}3.55 \\
3.40 \\
3.15 \\
3.08 \\
3.65\end{array}$ & $\begin{array}{l}3.70 \\
3.25 \\
3.10 \\
3.45 \\
3.30\end{array}$ & $\begin{array}{l}2.15 \\
2.20 \\
2.45 \\
2.30 \\
2.20\end{array}$ & $\begin{array}{l}2.30 \\
2.45 \\
2.35 \\
2.40 \\
2.22\end{array}$ & \\
\hline $\begin{array}{l}11 \ldots \ldots \\
12 \ldots \ldots \\
13 \ldots \ldots \\
14 \ldots \ldots\end{array}$ & $\begin{array}{l}2.55 \\
2.80 \\
2.75 \\
2.62 \\
2.55\end{array}$ & $\begin{array}{l}\text { 3. } 10 \\
3.58 \\
3.72 \\
3.68\end{array}$ & $\begin{array}{l}2.90 \\
3.80 \\
4.45 \\
4.75 \\
3.55\end{array}$ & $\begin{array}{l}3.45 \\
3.80 \\
3.70 \\
3.30 \\
3.63\end{array}$ & $\begin{array}{l}3.18 \\
3.08 \\
3.42 \\
3.10 \\
2.92\end{array}$ & $\begin{array}{l}3.28 \\
3.50 \\
3.60 \\
4.05 \\
4.30\end{array}$ & $\begin{array}{l}2.60 \\
2.65 \\
2.70 \\
2.70 \\
2.70\end{array}$ & $\begin{array}{l}2.28 \\
2.35 \\
2.50 \\
2.35 \\
2.25\end{array}$ & \\
\hline $\begin{array}{l}16 . . \\
17 . \\
18 . \\
19 . \\
20 .\end{array}$ & $\begin{array}{l}2.65 \\
2.45 \\
2.50 \\
2.55 \\
2.65\end{array}$ & $\begin{array}{l}3.85 \\
3.20 \\
2.90 \\
3.02 \\
2.75\end{array}$ & $\begin{array}{l}3.35 \\
3.15 \\
2.70 \\
2.25 \\
2.62\end{array}$ & $\begin{array}{l}3.72 \\
3.65 \\
3.42 \\
3.65 \\
3.93\end{array}$ & $\begin{array}{l}2.50 \\
3.12 \\
3.30 \\
3.25 \\
3.33\end{array}$ & $\begin{array}{l}4.55 \\
4.10 \\
3.45 \\
3.48 \\
3.40\end{array}$ & $\begin{array}{l}2.45 \\
2.50 \\
2.35 \\
2.55 \\
2.55\end{array}$ & $\begin{array}{l}2.22 \\
2.28 \\
2.35 \\
2.30 \\
2.50\end{array}$ & \\
\hline $\begin{array}{l}21 \ldots \ldots \ldots \\
22 \ldots \ldots \ldots \\
23 \ldots \ldots \\
24 \ldots \ldots \\
25 \ldots \ldots \\
25 \ldots \\
\end{array}$ & $\begin{array}{l}2.70 \\
3.05 \\
2.85 \\
2.85 \\
2.55\end{array}$ & $\begin{array}{l}2.55 \\
2.72 \\
2.60 \\
2.68 \\
2.88\end{array}$ & $\begin{array}{l}2.70 \\
2.72 \\
4.58 \\
4.95 \\
4.82\end{array}$ & $\begin{array}{l}3.55 \\
3.30 \\
2.98 \\
3.30 \\
3.63\end{array}$ & $\begin{array}{l}2.70 \\
3.25 \\
2.83 \\
3.30 \\
2.50\end{array}$ & $\begin{array}{l}2.90 \\
3.30 \\
3.40 \\
3.15 \\
4.05\end{array}$ & $\begin{array}{l}2.78 \\
2.88 \\
2.95 \\
3.02 \\
3.02\end{array}$ & $\begin{array}{l}2.40 \\
2.45 \\
2.25 \\
2.15 \\
2.15\end{array}$ & \\
\hline $\begin{array}{l}26 \ldots \\
27 \ldots \\
28 \ldots \\
29 \ldots \\
30 \ldots \\
31 \ldots \\
\end{array}$ & $\begin{array}{l}2.35 \\
2.50 \\
2.15 \\
2.45 \\
2.85 \\
2.82\end{array}$ & $\begin{array}{l}2.75 \\
2.68 \\
2.58 \\
2.75 \\
\cdots \ldots\end{array}$ & $\begin{array}{l}3.85 \\
3.68 \\
3.28 \\
3.25 \\
3.32 \\
3.50\end{array}$ & $\begin{array}{l}4.70 \\
5.95 \\
5.78 \\
5.45 \\
5.18\end{array}$ & $\begin{array}{l}3.85 \\
4.50 \\
4.35 \\
5.02 \\
5.15 \\
5.17\end{array}$ & $\begin{array}{l}3.95 \\
3.60 \\
4.10 \\
4.30 \\
3.70\end{array}$ & $\begin{array}{l}3.02 \\
2.78 \\
2.40 \\
2.38 \\
2.55 \\
2.60\end{array}$ & $\begin{array}{l}2.22 \\
2.22 \\
2.20 \\
2.25 \\
2.02 \\
1.95\end{array}$ & \\
\hline
\end{tabular}

Note.--Effect of ice conditions not known. As evidenced by the measurements made in January and February, 1908, and December, 1907, it must have been slight.

Rating table for Red Cedar River at Menominee, Wis., for 1907 and 1908.

\begin{tabular}{|c|r|r|r|r|r|r|r|}
\hline $\begin{array}{c}\text { Gage } \\
\text { height. }\end{array}$ & $\begin{array}{c}\text { Dis- } \\
\text { charge. }\end{array}$ & $\begin{array}{c}\text { Gage } \\
\text { height. }\end{array}$ & $\begin{array}{c}\text { Dis- } \\
\text { charge. }\end{array}$ & $\begin{array}{c}\text { Gage } \\
\text { height. }\end{array}$ & $\begin{array}{c}\text { Dis- } \\
\text { charge. }\end{array}$ & $\begin{array}{c}\text { Gage } \\
\text { height. }\end{array}$ & $\begin{array}{c}\text { Dis- } \\
\text { charge. }\end{array}$ \\
\hline Feet. & Sec.-ft. & Feet. & Sec.ft. & Feet. & Sec.ft. & Feet. & Sec.-ft. \\
0.50 & 100 & 1.80 & 491 & 3.10 & 1,317 & 4.80 & 3,360 \\
0.60 & 124 & 1.90 & 531 & 3.20 & 1,411 & 5.00 & 3,640 \\
0.70 & 149 & 2.00 & 574 & 3.30 & 1,509 & 5.20 & 3,925 \\
0.80 & 175 & 2.10 & 621 & 3.40 & 1,611 & 5.40 & 4,215 \\
0.90 & 202 & 2.20 & 671 & 3.50 & 1,717 & 5.60 & 4,510 \\
1.00 & 230 & 2.30 & 725 & 3.60 & 1,825 & 5.80 & 4,810 \\
1.10 & 258 & 2.40 & 783 & 3.70 & 1,935 & 6.00 & 5,110 \\
1.20 & 287 & 2.50 & 845 & 3.80 & 2,047 & 6.20 & 5,420 \\
1.30 & 318 & 2.60 & 912 & 3.90 & 2,162 & 6.40 & 5,730 \\
1.40 & 350 & 2.70 & 984 & 4.00 & 2,280 & 6.60 & 6,040 \\
1.50 & 383 & 2.80 & 1,060 & 4.20 & 2,535 & 6.80 & 6,360 \\
1.60 & 417 & 2.90 & 1,141 & 4.40 & 2,800 & & \\
1.70 & 453 & 3.00 & 1,227 & 4.60 & 3,080 & & \\
\hline
\end{tabular}

NotE.-The above table is not applicable for ice or obstructed-channel conditions. It is based on 12 discharge measurements made during 1907 and 1908 and is fairly well defined between gage heights 2.0 feet and 6.0 feet. 
Monthly discharge of Red Cedar River at Menominee, Wis., fcr 1907 and 1908.

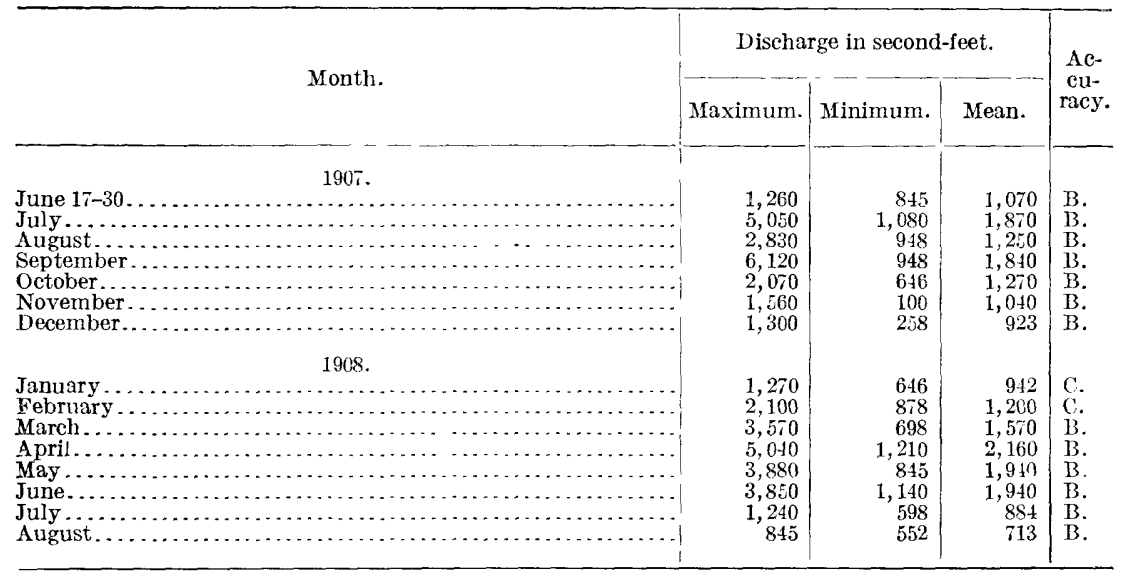

Note.-Open-channel rating applied throughout the winter periods; effect from ice probably small.

BLACK RIVER DRAINAGE BASIN.

DESCRIPTION.

The drainage basin of Black River lies west of the central part of the State of Wisconsin. The river rises in the northeastern part of Taylor County, flows in a generally southwesterly direction, and joins the Mississippi at La Crosse. The drainage basin is long and narrow and the tributaries are small. The more important ones are Poplar River and East Fork of Black River, both of which are tributary from the east. The total length of the river is about 145 miles; the total drainage area is about 2,272 square miles.

The basin is about 120 miles long and has an average width of 20 miles. All that portion of the river north of Black River Falls is in the crystalline rock. Through a large portion of this stretch the river has worn deeply into the rock, and the banks rise 40 to 60 feet above the river. In places the rock is covered with glacial drift. Below Black River Falls the river flows into a sandstone region; its valley is wide and the banks are usually low. The surface of the basin is level or rolling. The soil in the upper part of the basin is sandy, but a heavier clay soil is found in some places. This section was at one time covered with pine. In the lower part of the basin the soil is less sandy, as it contains more clay.

The elevation of the source of the river is about 1,400 feet; at Neillsville the elevation is 990 feet; at the mouth of the river the elevation is 628 feet.

The timber on this drainage basin has been about all cut off. The river is no longer used for running logs. The country is well settled. 
The mean annual rainfall is about 32 inches. The winter conditions are severe. The snowfall is heary, and ice forms from 1 to 2 feet in thickness and lasts about three months.

Storage possibilities have not been investigated. There are but few lakes in the drainage basin, and some of these may produce suitable reservoirs, but the basin is so well settled that the building of storage reservoirs would be prohibited by the cost of the land that would be flooded.

Conditions are not favorable for the development of water power, for the drainage area decreases rapidly as the river is ascended. The porous nature of the soil, however, compensates in a measure for the smallness of the drainage area, and power sites of considerable head, favorably located for the building of dams, are numerous. Many of these will undoubtedly be developed. Most of the valuable sites are above Black River Falls. (See Pl. III, B.)

The following gaging stations have been maintained in this drainage basin:

Black River at Neillsville, Wis., 1905-1908.

Black River at Melrose, Wis., 1902-3.

\section{BLACK RIVER SURVEY.}

In order to point out the power possibilities along Black River, a survey was made during 1906 from Black River Falls to Wisconsin Central Railway crossing. From the data collected on this survey sheets have been prepared showing a profile of the water surface, a plan of the river, contour along the bank, and prominent natural or artificial features. The results of this survey have been published on separate sheets and may be had upon application to the Director of the Geological Survey.

BLACK RIVER AT NEILlSVILLE, WIS.

This station, which is located at the lower highway bridge across Black River, about 700 feet below the Chicago, St. Paul, Minneapolis and Omaha Railroad bridge at Neillsville, Wis., was established April 7, 1905, to obtain data for use in studying water power, water supply and pollution problems.

The winter conditions are severe in this vicinity; ice forms to a thickness of 1 to 2 feet and modifies the relation between discharge and gage heights.

The datum of the gage has remained unchanged. The records are reliable and accurate.

Information in regard to this station prior to 1908 is contained in Bulletin XX of the Wisconsin Geological and Natural History Survey, entitled "Water powers of Wisconsin," by Leonard s. Smith. 
Discharge measurements of Black River at Neillsville, Wis., in 1907 and 1908.

\begin{tabular}{|c|c|c|c|c|c|}
\hline Date. & Ilydrographer. & Width. & $\begin{array}{l}\text { Area of } \\
\text { section. }\end{array}$ & $\begin{array}{l}\text { Gage } \\
\text { height. }\end{array}$ & $\begin{array}{c}\text { Dis- } \\
\text { charge. }\end{array}$ \\
\hline $\begin{array}{r}1907 . \\
\text { April } 3 \ldots . . .\end{array}$ & A. H. Horton. & $\begin{array}{l}\text { Fect. } \\
\quad 184\end{array}$ & $S q . f t$. & $\begin{array}{l}\text { Feet. } \\
6.52\end{array}$ & Sec. ft. \\
\hline May $3 \ldots . .$. & G..do & 139 & 346 & 4.14 & $\begin{array}{r}537 \\
\quad 534 \\
\end{array}$ \\
\hline July 13. . & $\begin{array}{l}\text { G. A. Gray. } \\
\text { …. do ....... }\end{array}$ & $\begin{array}{l}l 4 f \\
142\end{array}$ & ${ }_{226}^{257}$ & $\begin{array}{l}3.39 \\
3.52\end{array}$ & $\begin{array}{l}3344 \\
255\end{array}$ \\
\hline August $15 \ldots$. & …do do & 116 & 108 & 2.70 & שט \\
\hline September is .. & …do. & $\begin{array}{l}116 \\
121\end{array}$ & $\begin{array}{l}108 \\
140\end{array}$ & $\begin{array}{l}2 .{ }^{-} 5 \\
3.00\end{array}$ & $\begin{array}{r}67 \\
107\end{array}$ \\
\hline Do.. & ......do. & 121 & 140 & 2.97 & \\
\hline $\begin{array}{l}\quad 1908 . \\
\text { July } 20 \ldots \ldots \ldots \\
\text { September } 15 \ldots\end{array}$ & $\begin{array}{l}\text { G. A. Gray } \ldots \\
\text {. do }\end{array}$ & $\begin{array}{l}129 \\
100\end{array}$ & $\begin{array}{r}218 \\
78\end{array}$ & $\begin{array}{l}3.50 \\
2.10\end{array}$ & $\begin{array}{r}246 \\
37\end{array}$ \\
\hline
\end{tabular}

Daily gage height, in feet, of Black River at Neillsville, Wis., for 1907 and 1908.

[A. Bissell, observer.]

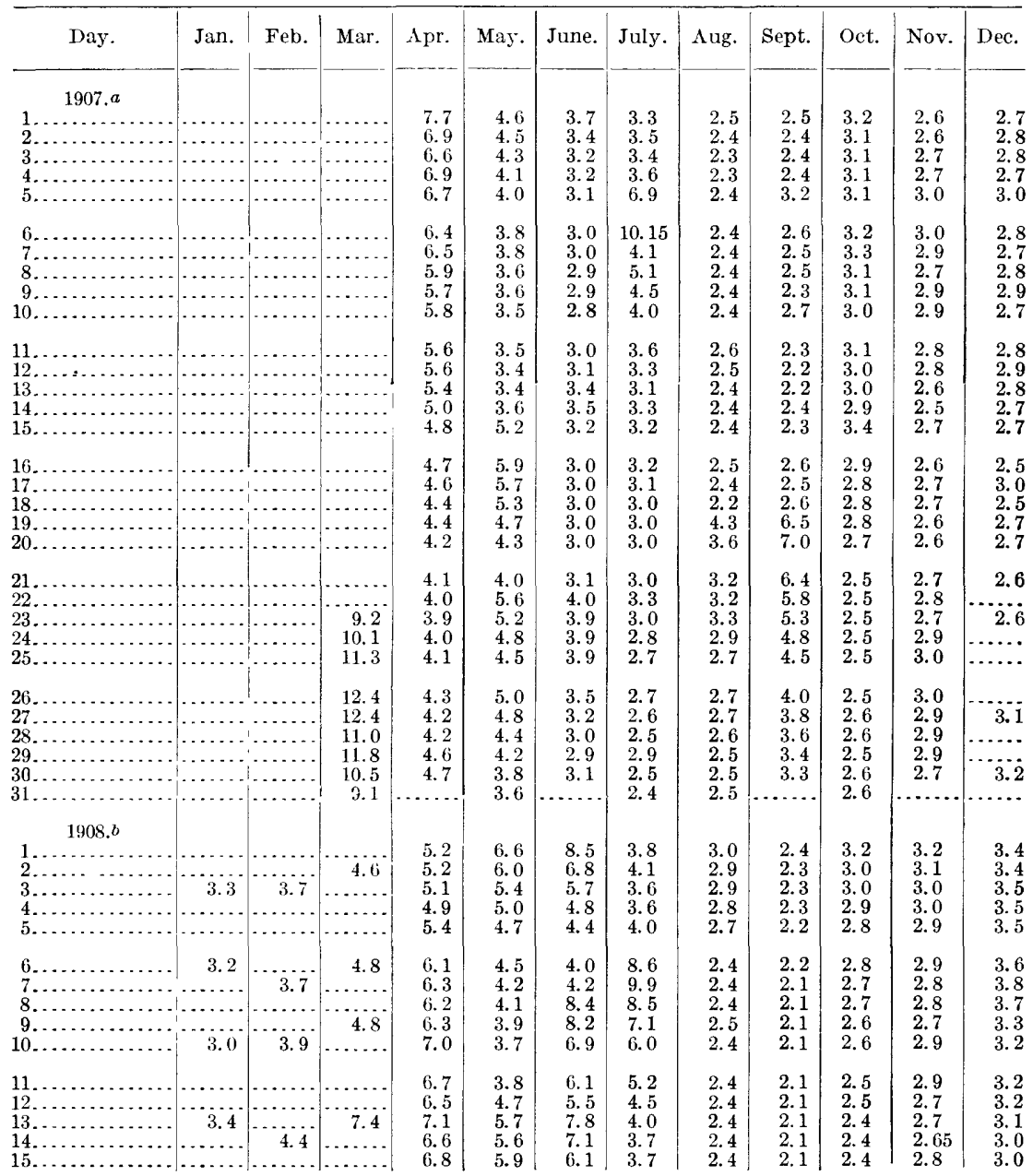

$a$ Stream frozen January 1 to March 22 and December 22-31, 1907; readings to water surface.

$b$ Ice conditions during January, February, March, and after December 18, 1908. Gage readings during the frozen periods taken to water surface. 
Daily gage height, in feet, of Black River at Neillsville, Wis., for 190' and 1908-Cont'd

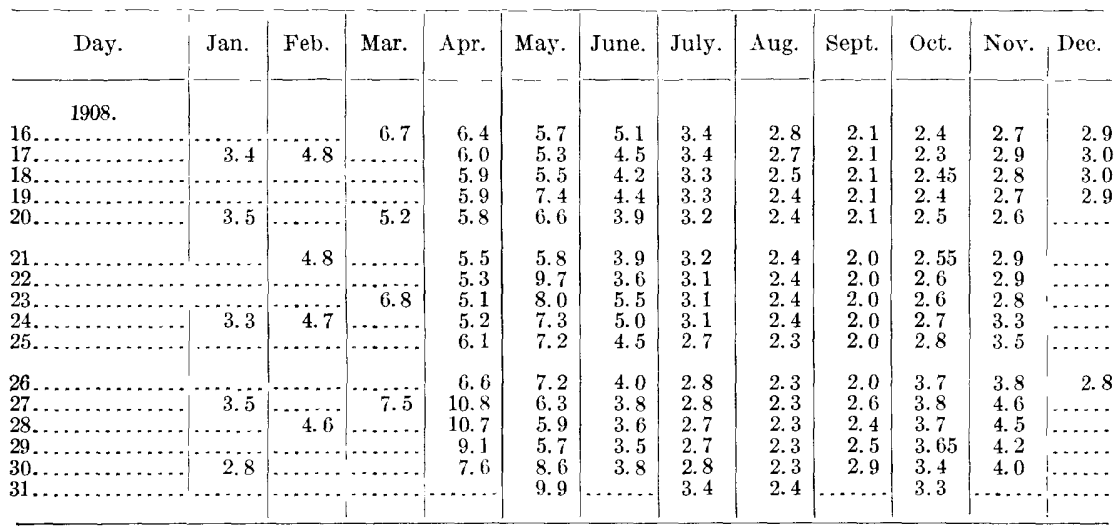

Rating table for Black River at Neillsville, Wis., for 1907 and 1908.

\begin{tabular}{|r|r|r|r|r|r|r|r|}
\hline $\begin{array}{c}\text { Gage } \\
\text { height. }\end{array}$ & $\begin{array}{c}\text { Dis- } \\
\text { charge. }\end{array}$ & $\begin{array}{c}\text { Gage } \\
\text { height. }\end{array}$ & $\begin{array}{c}\text { Dis- } \\
\text { charge. }\end{array}$ & $\begin{array}{c}\text { Gage } \\
\text { height. }\end{array}$ & $\begin{array}{c}\text { Dis- } \\
\text { charge. }\end{array}$ & $\begin{array}{c}\text { Gage } \\
\text { height. }\end{array}$ & $\begin{array}{c}\text { Dis- } \\
\text { charge. }\end{array}$ \\
\hline & - & & & & & \\
Feet. & Sec.-ft. & Feet. & Sec.-ft. & Feet. & Sec.-ft. & Feet. & Sec.ft. \\
2.00 & 29 & 3.30 & 183 & 4.60 & 817 & 6.80 & 2,480 \\
2.10 & 33 & 3.40 & 215 & 4.70 & 878 & 7.00 & 2.660 \\
2.20 & 38 & 3.50 & 251 & 4.80 & 941 & 7.20 & 2.850 \\
2.30 & 43 & 3.60 & 291 & 4.90 & 1,005 & 7.40 & 3,050 \\
2.40 & 49 & 3.70 & 334 & 5.00 & 1,070 & 7.60 & 3.250 \\
2.50 & 55 & 3.80 & 380 & 5.20 & 1,204 & 7.80 & 3,460 \\
2.60 & 62 & 3.90 & 429 & 5.40 & 1,346 & 8.00 & 3,680 \\
2.70 & 70 & 4.00 & 480 & 5.60 & 1,495 & 9.00 & 4,820 \\
2.80 & 80 & 4.10 & 533 & $\mathbf{5 . 8 0}$ & 1,645 & 10.00 & 6,020 \\
2.90 & 92 & 4.20 & 587 & 6.00 & 1,800 & 11.00 & 7,300 \\
3.00 & 108 & 4.30 & 642 & 6.20 & 1,960 & 12.00 & 8.700 \\
3.10 & 129 & 4.40 & 699 & 6.40 & 2,130 & 13.00 & 10.200 \\
3.20 & 154 & 4.50 & 757 & 6.60 & 2,300 & & \\
\hline
\end{tabular}

Note.-The above table is not applicable for ice or obstructed-channel conditions. It is based on discharge measurements made during 1905 to 1908 and is well defined between gage heights 2.7 feet and 8 feet.

Monthly discharge of Block River at Neillsville, Wis., for 1907 and 1908.

[Drainage area, 675 square miles.]

\begin{tabular}{|c|c|c|c|c|c|c|}
\hline \multirow[b]{2}{*}{ Month. } & \multicolumn{4}{|c|}{ Discharge in second-feet. } & \multirow{2}{*}{$\begin{array}{l}\text { Run-off } \\
\text { (depth in } \\
\text { inches on } \\
\text { drainage } \\
\text { area). }\end{array}$} & \multirow[b]{2}{*}{$\begin{array}{l}\text { Aceu- } \\
\text { racy. }\end{array}$} \\
\hline & Maximum. & Minimum. & Mean. & $\begin{array}{c}\text { Per } \\
\text { square } \\
\text { mile. }\end{array}$ & & \\
\hline $190 \bar{r}$. & & & & & & \\
\hline March $23-31 \ldots \ldots \ldots \ldots \ldots \ldots \ldots$ & 9.300 & 4,940 & 7,200 & 10.7 & 3.58 & B. \\
\hline 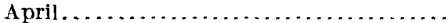 & 3.350 & 429 & 1,280 & 1.90 & 2.12 & A. \\
\hline 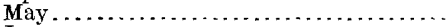 & 1,720 & 215 & 707 & 1.05 & 1.21 & A. \\
\hline 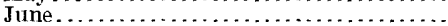 & 480 & 80 & 183 & .271 & .30 & B. \\
\hline July ............ & 6,200 & 49 & 487 & .721 & .83 & B. \\
\hline August ........ & 642 & 38 & 91.7 & .136 & .16 & 13. \\
\hline September..... & 2,660 & 38 & 473 & .701 & .78 & B. \\
\hline$\ldots \ldots \ldots \ldots$ & 215 & 55 & 98.7 & .146 & .17 & B. \\
\hline$\therefore \ldots \ldots \ldots \ldots \ldots \ldots$ & 108 & 55 & 79.1 & .117 & .13 & B. \\
\hline December $1-21 \ldots$ & 108 & 55 & 76.8 & .114 & .89 & B. \\
\hline 1908. & & & & & & \\
\hline 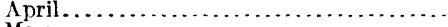 & 7,040 & 1,000 & 2,300 & 3.41 & 3.80 & A. \\
\hline 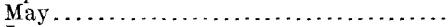 & 5,900 & 334 & 1.960 & 2.90 & 3.34 & 1 . \\
\hline 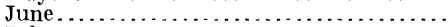 & 4,230 & 251 & 1,410 & 2.09 & 2.33 & A. \\
\hline July ............ & 5,900 & 70 & 847 & 1.25 & 1.44 & $\Lambda$. \\
\hline August . . . . . . . & 108 & 43 & 56.3 & .083 & .10 & $\mathrm{C}$. \\
\hline$\ldots \ldots \ldots \ldots \ldots$ & 92 & 29 & 38.3 & .057 & .06 & D. \\
\hline 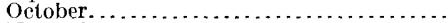 & 380 & 43 & 112 & .166 & .19 & 13. \\
\hline November . . & 817 & 62 & 183 & .271 & .30 & B. \\
\hline December $1-19 . \ldots$. & 380 & 92 & 188 & .279 & .20 & B. \\
\hline
\end{tabular}




\section{WISCONSIN RIVER DRAINAGE BASIN.}

\section{DESCRIPTION.}

The drainage basin of Wisconsin River, except for a few square miles, lies wholly within the State of Wisconsin. The river rises in Lake Vieux Desert, lying directly on the boundary line between upper Michigan and Wisconsin, whence it flows in a southwesterly direction for about 300 miles to the city of Portage near the center of Portage County. At this point it turns westward and empties into the Mississippi River at Prairie du Chien, Wis., about 40 miles from the southern boundary of the State. The important tributaries beginning at the sources are as follows: On the west or right bank of the river, Tomahawk, Rib, Big Eau Pleine, Eau Pleine, Yellow, Lemonweir, Baraboo, Pine, and Kickapoo rivers; on the left bank, Pelican, Prairie, Eau Claire, and Plover rivers.

The total length of the river is about 429 miles; the total drainage area is about 12,280 square miles.

The drainage area is comparatively long and narrow, being about 225 miles long and about 50 miles average width. The river flows, for the most part, in the eastern half of its basin; below Portage it flows within 10 miles of its southern edge. At Portage the divide between Wisconsin River and Fox River is so low that during high water the current in one of the tributaries of the Wisconsin is reversed and flows into the Fox.

Like all the large rivers of the State, the Wisconsin heads in the high drift-covered region. That part of the Wisconsin River basin which lics above Nekoosa, including more than half of the drainage area, is underlain by crystalline rocks, which, by presenting a barrier to erosion, cause numerous rapids that afford excellent sites for water power. Below Nekoosa the crystalline rocks give way to the softer sandstone, the disintegration of which has made the bed of the river one succession of shifting sand bars almost without interruption to its mouth. Where this formation is near the surface in the surrounding country the soil is very light and in places even sterile. North of Nekoosa this sandy belt rapidly narrows, and at Merrill, Wis., about 90 miles above, almost entirely disappears, being replaced by the clayey loams and loamy clays. North of Tomahawk the clays are again replaced by samdy soils containing gravel and by bowlders and glacial drift.

In general, the country is level or undulating. In places decided ridges break the surface, as, for example, the Baraboo ranges of quartzite and the bluffs along the lower river. The northern part of the drainage area is covered with innumerable lakes and swamps, which tend to make the flow of the stream uniform and steady. 
According to the United States Engineer Corps, the elevation of Lake Vieux Desert, the source of the river, is about 1,650 feet, the elevation at the mouth is about 604 feet, or a total fall of about 1,050 feet. About 634 feet of this fall occur in the 150 miles between Rhinelander and Nekoosa, an average of over 4 feet to the mile. This descent is concentrated at many places, producing a large number of valuable water powers.

The dense growth of pine which covered the upper part of the drainage basin of Wisconsin River has nearly all been cut off, and a thick growth of brush and second-growth timber has taken its place; large areas have been brought uncler cultivation. In some places this second growth has been burned over, leaving almost impenetrable thickets of brush and dead timber. The effect of this new growth of brush and timber on the run-off is probably about the same as the pine forests which it has replaced.

The mean annual rainfall on the headwaters of the river is about 31 inches; at the lower part of the basin the rainfall is about 34 inches.

The winter conditions, except in the very lowest part of the basin, are severe. The snowfall is comparatively heavy and stays on the ground for long periods, and the streams are covered with ice from 1 to 2 feet in thickness for three to four months. These severe conditions tend to make the winter season the period of minimum flow, and discharge measurements taken during the ice period are very valuable.

The basin affords numerous opportunities for storage. The United States Engineer Corps located and surveyed eight reservoir sites at the headwaters of Wisconsin River to aid navigation of the Mississippi River. The capacity of these reservoirs is about $20,000,000,000$ cubic feet, and it was estimated that a flow of 3,000 cubic feet per second could be maintained for three months. Such a flow would nearly double the low-water flow of the river and its resulting water power. Several of these reservoirs have been constructed by private parties for water-power development. The Wisconsin Valley Improvement Company has been authorized by law to construct, acquire, and maintain a system of reservoirs located on the tributaries of the Wisconsin River north of the south line of township 34, about 6 miles below Tomahawk, for the purpose of producing a uniform flow of water, etc. The law provides that when this company shall have completed reservoirs of a capacity of $2,000,000,000$ cubic feet it may collect and receive reasonable tolls from the owner of every improved and operated water power located on the river below such reservoirs. The tolls are to yield not to exceed 6 per cent on the actual investment. 
The opportunities for water-power development in this drainage basin are numerous. The development of some of the larger sites is beginning, but many valuable sites on the main river and on the tributaries are still undeveloped. (See Pl. V.)

The stream is used quite extensively for logging, but the greater part of the large timber has been cut off and lumbering is decreasing, although considerable pulp wood is being run on the river. The dams at the water-power sites lo not interfere seriously with the small run of $\log _{\mathrm{s}}$ at the present time.

The following gaging stations have been maintained on the Wisconsin River, viz:

Wisconsin River near Rhinelander, Wis., 1905-1908.

Wisconsin River at Merrill, Wis., 1902-1908.

Wisconsin River near Necedah, Wis., 1902-1908.

Wisconsin River at Muscoda, Wis., 1902-1903.

WISCONSIN RIVER SURVEY.

In order to point out the power possibilities along the Wisconsin River a survey was made during 1906 between Sauk City and Dekorra and between Lewiston Station and Jersey City. From the data collected sheets have been prepared, showing a profile of the water surface, a plan of the river, contour along the bank, and prominent natural or artificial features. The results of this survey have been published on separate sheets and may be had upon application to the Director of the Geological Survey.

\section{EAU CLAIRE RIVER SURVEY.}

In order to point out the power possibilities along the Eau Claire River, a survey was made during 1906 from the mouth to Johnson. From the data collected sheets have been prepared, showing a profile of the water surface, a plan of the river, contour along the bank, and prominent natural or artificial features. The results of this survey have been published on separate sheets and may be had upon application to the Director of the Geological Survey.

WISCONSIN RIVER NEAR RHINELANDER, WIS.

This station, which is located at a highway bridge about 8 miles southwest of Rhinelander, Wis., at Forbes \& Wixson's power station, was established December 1, 1905, to obtain data for water power, water-supply, pollution, and storage problems.

Pelican River enters about 8 miles above the station.

The winter conditions in this section are severe, but the operation of the power plant about 400 feet above the bridge prevents the river from freezing at the gaging section, and ice forms only in narrow strips along the shores. The pond above the dam modifies the 


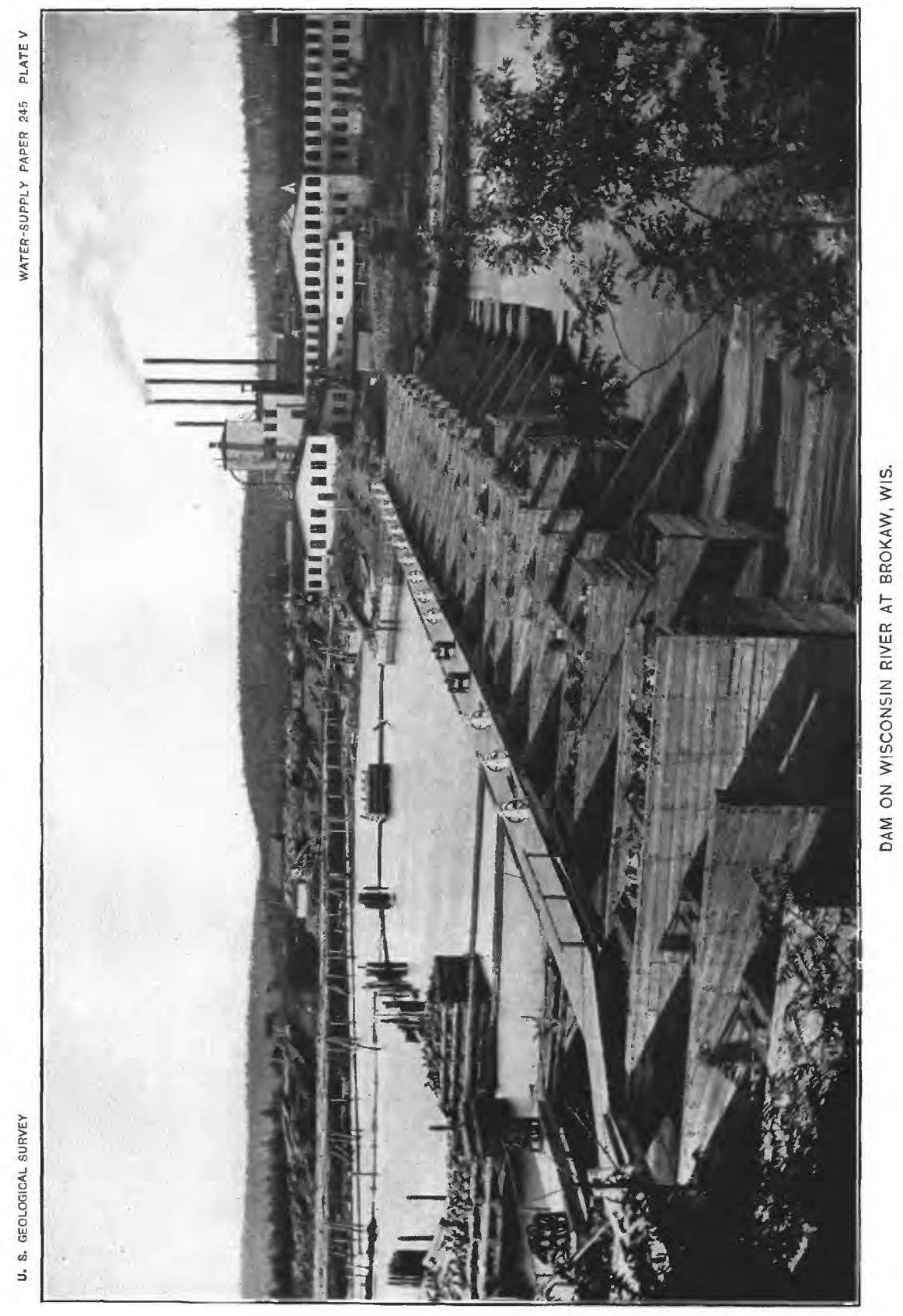


normal flow, and the total range in gage height is small. The fluctuations of the load on the turbines may also affect discharge measurements.

The datum of the gage has remained unchanged, and aside from the above conditions the records are reliable and accurate.

Information in regard to this station prior to 1908 is contained in Bulletin XX of the Wisconsin Geological and Natural History Survey, entitled "Water powers of Wisconsin," by Leonard S. Smith.

Discharge measurements of Wisconsin River near Rhinelander, Wis., 1906 to 1908.

\begin{tabular}{|c|c|c|c|c|c|}
\hline Date. & Iydrographer. & Width. & $\begin{array}{l}\text { Area of } \\
\text { section. }\end{array}$ & $\begin{array}{l}\text { Gage } \\
\text { height. }\end{array}$ & $\begin{array}{l}\text { Dis- } \\
\text { charge. }\end{array}$ \\
\hline $\begin{array}{c}1906 . \\
\text { January } 27 .\end{array}$ & M. s. Brennan... & $\begin{array}{l}\text { Fcet. } \\
209\end{array}$ & $S q \cdot f t$. & Feet. & Src.-ft \\
\hline April $17 . . . . . .$. & 1Forton and Brennain. & 215 & 822 & 4. 25 & 2,580 \\
\hline June $12 \ldots \ldots$ & M. s. Brennan......... & 216 & 656 & 3.60 & 2,050 \\
\hline $\begin{array}{l}1907 . \\
\text { April } 6 .\end{array}$ & A. If Horton. & 211 & 708 & & \\
\hline Do.. & A. & 211 & $\begin{array}{l}708 \\
712\end{array}$ & $\begin{array}{l}3.94 \\
3.97\end{array}$ & $\begin{array}{l}2,390 \\
2,620\end{array}$ \\
\hline Do. & .....do. & 211 & 785 & 4.29 & 2,820 \\
\hline October $17 \ldots$ & G. A. Gray $\ldots \ldots \ldots \ldots \ldots \ldots \ldots \ldots \ldots \ldots \ldots \ldots \ldots \ldots \ldots \ldots \ldots \ldots \ldots \ldots$ & 196 & 330 & 2.55 & 704 \\
\hline $\begin{array}{r}1908 . \\
\text { July } 17 \ldots .\end{array}$ & G. 1. Gray ........... & 200 & 353 & 2.30 & 690 \\
\hline
\end{tabular}

Daily gage height, in feet, of Wisconsin River near Rhinelander, Wis., for 1907 and 1908.

[Charles IIagen, olserver.]

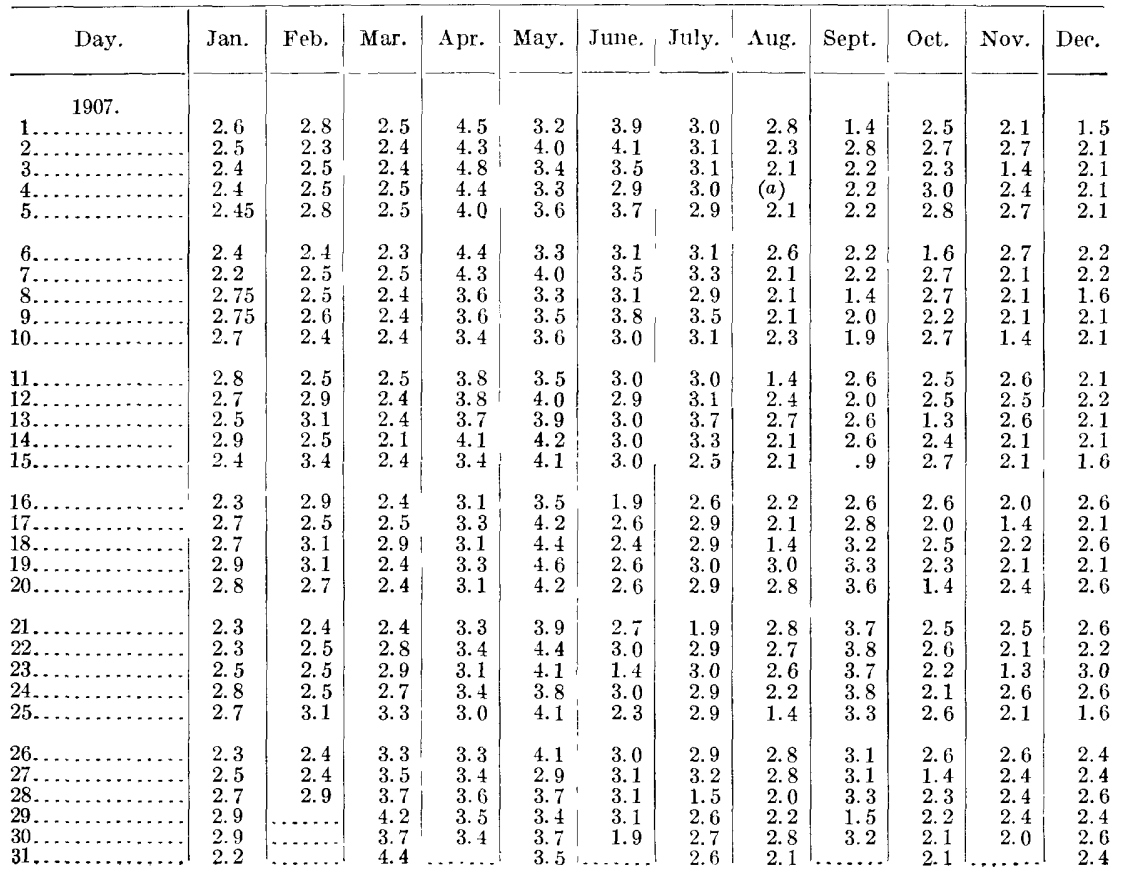

$a$ Water standing in pools, 
Daily gage height, in feet, of Wisconsin River near Rhinelander, Wis., for $190 \%$ and 1908 - Continued.

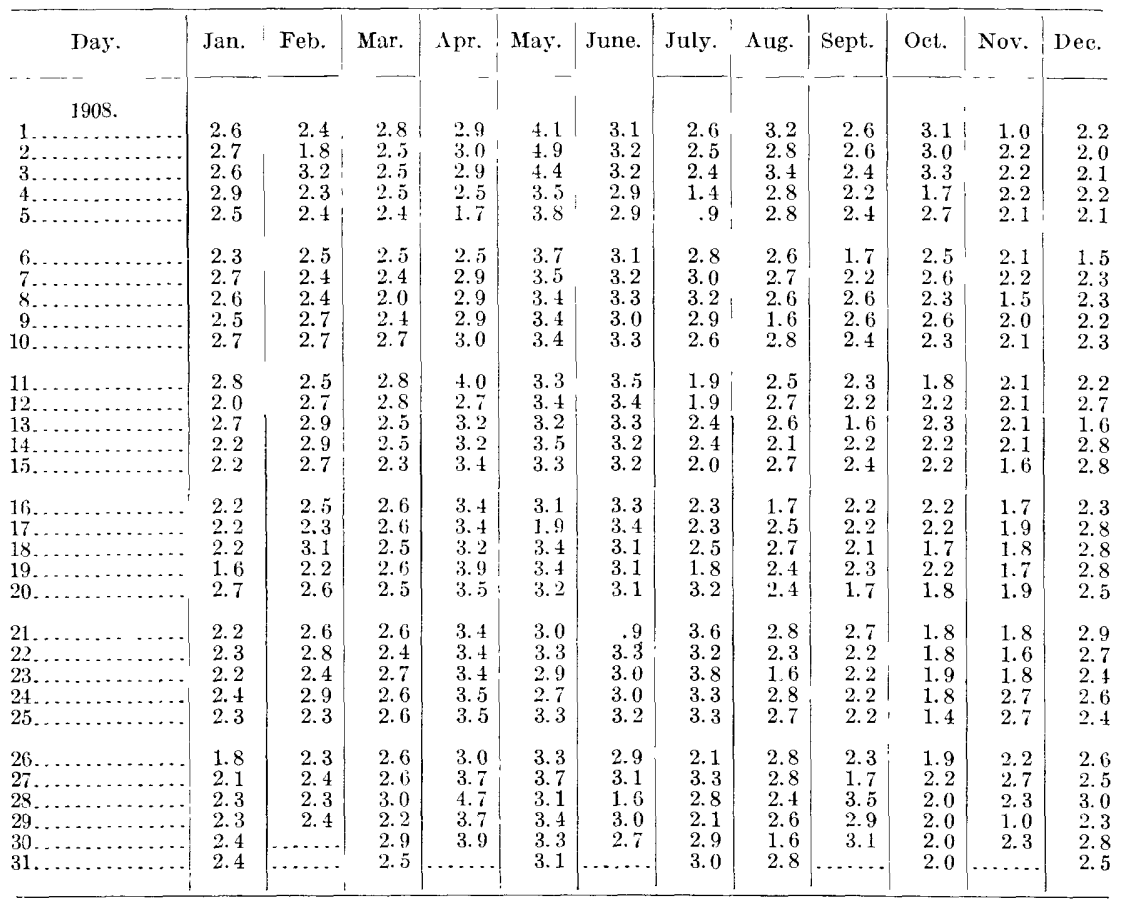

Rating table for Wisconsin Rirer neir Rhinelander, Wis., 1905 to 1908.

\begin{tabular}{|c|c|c|c|c|c|c|c|}
\hline $\begin{array}{c}\text { Gage } \\
\text { height. }\end{array}$ & $\begin{array}{c}\text { Dis- } \\
\text { charge. }\end{array}$ & $\begin{array}{l}\text { Gage } \\
\text { height. }\end{array}$ & $\begin{array}{c}\text { Dis- } \\
\text { charge. }\end{array}$ & $\begin{array}{c}\text { Gage } \\
\text { height. }\end{array}$ & $\begin{array}{c}\text { Dis- } \\
\text { charge. }\end{array}$ & $\begin{array}{l}\text { Gage } \\
\text { height. }\end{array}$ & $\begin{array}{c}\text { Dis- } \\
\text { charge. }\end{array}$ \\
\hline $\begin{array}{l}\text { Feet. } \\
0.90 \\
1.00 \\
1.10 \\
1.20 \\
1.30 \\
1.40 \\
1.50 \\
1.60 \\
1.70 \\
1.80\end{array}$ & $\begin{array}{r}\text { Sec. } f t \text {. } \\
0 \\
15 \\
31 \\
52 \\
77 \\
106 \\
140 \\
179 \\
223 \\
270\end{array}$ & $\begin{array}{l}\text { Fect. } \\
1.90 \\
2.00 \\
2.10 \\
2.20 \\
2.30 \\
2.40 \\
2.50 \\
2.60 \\
2.70 \\
2.80\end{array}$ & $\begin{array}{r}\text { Sec. } f t . \\
324 \\
384 \\
452 \\
526 \\
606 \\
690 \\
775 \\
870 \\
980 \\
1,090\end{array}$ & $\begin{array}{l}\text { Feet. } \\
2.90 \\
3.00 \\
3.10 \\
3.20 \\
3.30 \\
3.40 \\
3.50 \\
3.60 \\
3.70 \\
3.80\end{array}$ & $\begin{array}{r}\text { Sec.-ft. } \\
1,205 \\
1,320 \\
1,435 \\
1,550 \\
1,665 \\
1,780 \\
1,895 \\
2,010 \\
2,125 \\
2,2.0\end{array}$ & $\begin{array}{l}\text { Feet. } \\
3.90 \\
4.00 \\
4.20 \\
4.40 \\
4.40 \\
4.80 \\
5.00\end{array}$ & $\begin{array}{r}\text { Sec.-ft. } \\
2.355 \\
2.470 \\
2.700 \\
2,945 \\
3,200 \\
3.460 \\
3,720\end{array}$ \\
\hline
\end{tabular}

Note.-The above table is not applicable for ice or obstrueted-channel conditions. It is based on eight discharge measurements made during 1906-1908 and is well defined between gage heights 2.5 and 4.5 feet. 
Monthly discharge of Wisconsin River near Rhinelander, Wis., 1905 to 1908.

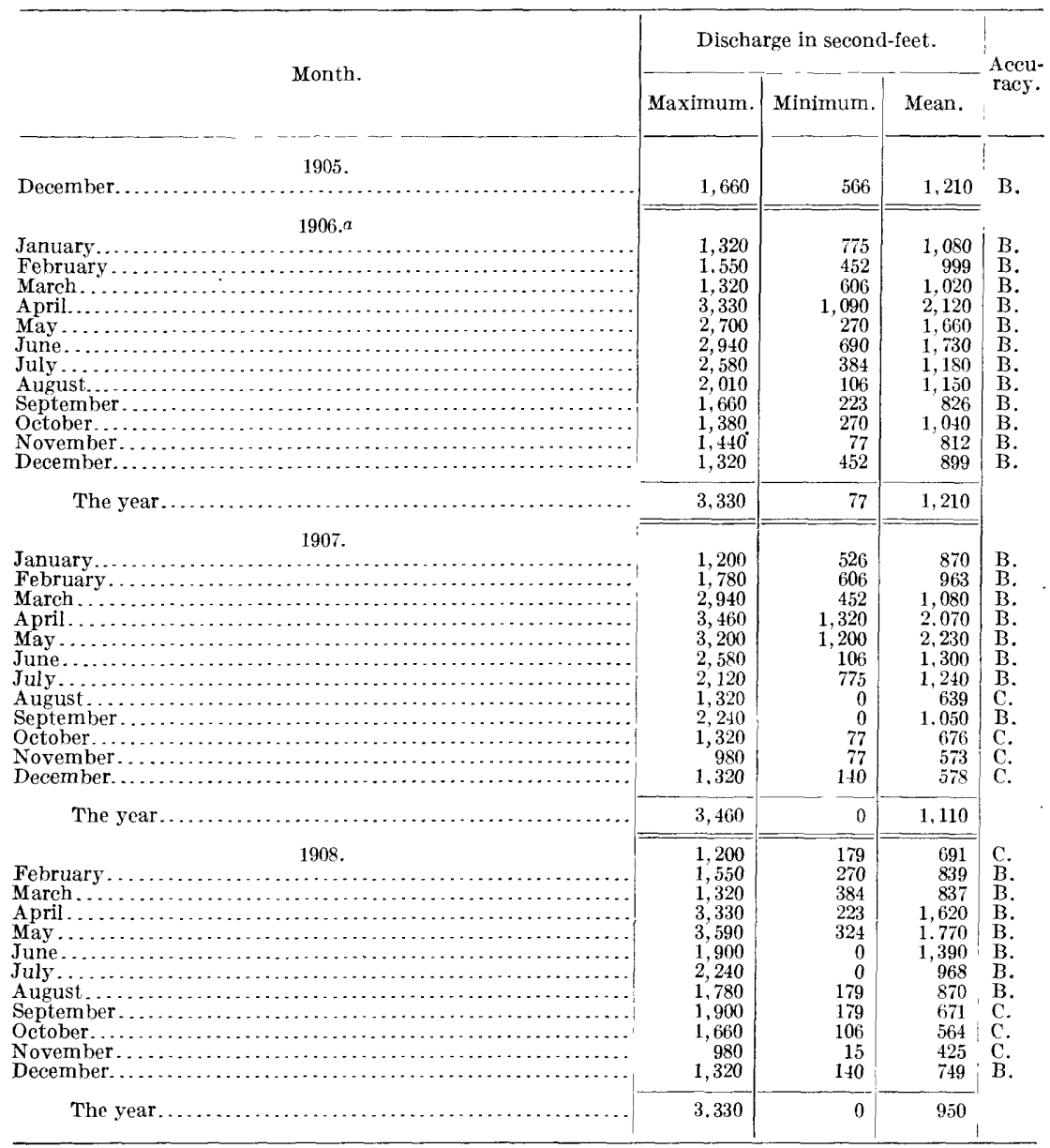

$a$ Because of a constant error in gage readings, 1906 gage heights after October 17 as published in WaterSupply Paper 207 have been reduced 0.1 foot before the application of the rating table.

WISCONSIN RIVER AT MERRILL, WIS.

This station, which is located at a highway bridge at the east end of Merrill, Wis., was established November 17, 1902, to obtain data for water-power, water-supply, pollution, and storage problems. The bridge is about 1,000 feet below the dam. Prairie River enters from the east about one-half mile above the station. The flow is somewhat modified by the dam and power plants above the station.

The current is so swift that ice does not form across the section, and there is open water at the gage the year round, but winter conditions are severe, and during the ice period the relation between gage height and discharge is affected by backwater. The stream is 22110 -IRR $245-10-7$ 
used considerably for log running, and jams below the measuring section may affect the gage heights for short periods.

The datum of the gage has remained unchanged; the records are reliable and accurate except as conditions above may affect the readings.

Information in regard to this station is contained in Bulletin XX of the Wisconsin Geological and Natural History Survey, entitled "Water powers of Wisconsin," by Leonard S. Smith.

Discharge measurements of Wisconsin River at Merrill, Wis., in 1907 and 1908.

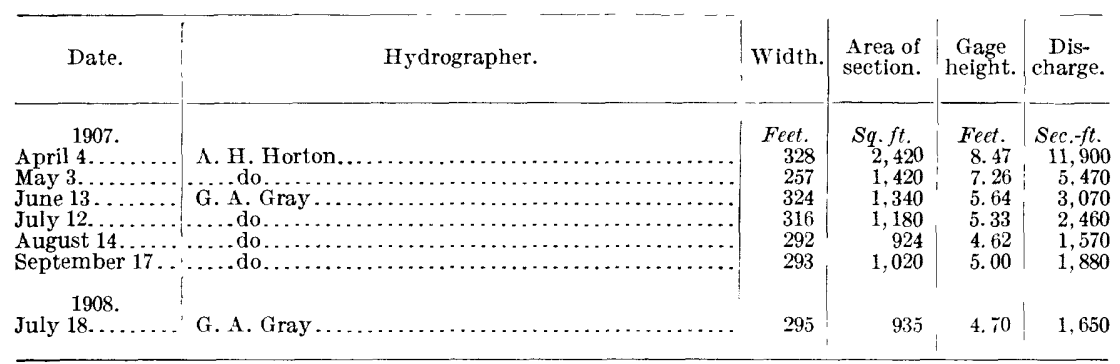

Daily gage height, in feet, of Wisconsin River at Merrill, Wis., for $190 \%$ and 1908.

[A. F. Lueck, observer.]

\begin{tabular}{|c|c|c|c|c|c|c|c|c|c|c|c|c|}
\hline Day. & Jan. & Feb. & Mar. & Apr. & May. & June. & July. & Aug. & Sept. & Oct. & Nov. & Dec. \\
\hline $\begin{array}{c}1 \\
1 \ldots \\
2 \ldots \\
3 \ldots \\
4 \ldots \\
5 \ldots\end{array}$ & $\begin{array}{l}4.9 \\
5.15 \\
5.0 \\
4.85 \\
4.8\end{array}$ & $\begin{array}{l}5.15 \\
5.0 \\
5.2 \\
5.1 \\
5.2\end{array}$ & $\begin{array}{l}5.2 \\
5.2 \\
5.3 \\
5.45 \\
5.75\end{array}$ & $\begin{array}{l}8.6 \\
8.5\end{array}$ & $\begin{array}{l}6.95 \\
6.85 \\
7.3 \\
7.05 \\
7.35\end{array}$ & $\begin{array}{l}5.8 \\
5.4 \\
5.65 \\
5.2 \\
5.8\end{array}$ & $\begin{array}{l}5.8 \\
5.35 \\
5.95 \\
5.55 \\
5.6\end{array}$ & $\begin{array}{l}4.8 \\
4.95 \\
4.75 \\
4.3 \\
4.65\end{array}$ & $\begin{array}{l}4.1 \\
3.5 \\
3.8 \\
4.05 \\
4.5\end{array}$ & & $\begin{array}{l}5.25 \\
5.2 \\
5.05 \\
3.7 \\
4.7\end{array}$ & $\begin{array}{l}4.4 \\
4.35 \\
3.9 \\
4.4 \\
4.35\end{array}$ \\
\hline $\begin{array}{r}6 . . \\
7 . \\
8 . \\
9 . \\
10 .\end{array}$ & $\begin{array}{l}4.95 \\
4.95 \\
5.0 \\
5.15 \\
5.25\end{array}$ & $\begin{array}{l}5.15 \\
5.05 \\
5.05 \\
5.2 \\
4.95\end{array}$ & $\begin{array}{l}5.25 \\
5.2 \\
5.1 \\
4.9 \\
5.4\end{array}$ & $\begin{array}{l}8.55 \\
8.1 \\
7.9 \\
7.2 \\
7.1\end{array}$ & $\begin{array}{l}7.1 \\
7.25 \\
8.3 \\
6.95 \\
6.5\end{array}$ & $\begin{array}{l}5.95 \\
5.75 \\
5.7 \\
5.55 \\
5.2\end{array}$ & & & $\begin{array}{l}4.15 \\
4.65 \\
4.4 \\
4.25 \\
3.3\end{array}$ & & $\begin{array}{l}4.9 \\
4.9 \\
4.85 \\
5.15 \\
3.55\end{array}$ & $\begin{array}{l}5.05 \\
4.6 \\
4.75 \\
4.8 \\
4.4\end{array}$ \\
\hline . & $\begin{array}{l}4 . \\
5.2 \\
5.1 \\
5.0 \\
5.0\end{array}$ & $\begin{array}{l}5.0 \\
5.1 \\
5.25 \\
5.2 \\
4.95\end{array}$ & $\begin{array}{l}5.25 \\
5.05 \\
5.25 \\
5.1 \\
4.75\end{array}$ & & $\begin{array}{l}6.8 \\
6.9 \\
6.55 \\
7.65 \\
8.05\end{array}$ & $\begin{array}{l}5.5 \\
5.4 \\
5.45 \\
6.2 \\
5.8\end{array}$ & $\begin{array}{l}5.5 \\
5.35 \\
5.8 \\
5.3\end{array}$ & & $\begin{array}{l}4.45 \\
4.85 \\
4.6 \\
4.2\end{array}$ & & $\begin{array}{l}4.10 \\
3.05 \\
4.2 \\
4.3\end{array}$ & $\begin{array}{l}4.3 \\
4.35 \\
3.85 \\
4.7 \\
4.7\end{array}$ \\
\hline 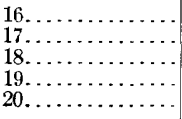 & $\begin{array}{l}0.0 \\
5.1 \\
5.15 \\
5.25 \\
5.1\end{array}$ & $\begin{array}{l}5.3 \\
4.9 \\
5.0 \\
5.0 \\
5.05\end{array}$ & $\begin{array}{l}4.7 \\
4.9 \\
4.75 \\
5.25 \\
5.15\end{array}$ & $\begin{array}{l}5.95 \\
6.2 \\
6.45\end{array}$ & & $\begin{array}{l}5.1 \\
4.7 \\
4.9 \\
5.4\end{array}$ & $\begin{array}{l}5.40 \\
5.65 \\
5.5 \\
5.8\end{array}$ & $\begin{array}{l}4.3 \\
4.1 \\
3.8 \\
3.95\end{array}$ & $\begin{array}{l}4.95 \\
5.1 \\
8.55 \\
9.2\end{array}$ & & $\begin{array}{l}4.0 \\
4.55 \\
4.7 \\
4.35 \\
4.9\end{array}$ & $\begin{array}{l}4.25 \\
4.3 \\
4.5 \\
4.3\end{array}$ \\
\hline 23. & $\begin{array}{l}5.05 \\
5.0 \\
5.5 \\
5.25 \\
5.2\end{array}$ & $\begin{array}{l}5.35 \\
5.35 \\
5.1 \\
5.1 \\
5.1\end{array}$ & $\begin{array}{l}5.4 \\
5.1 \\
5.1\end{array}$ & $\begin{array}{l}0.2 \\
6.9 \\
7.1 \\
6.9 \\
7.25\end{array}$ & $\begin{array}{l}7.05 \\
7.0 \\
7.0 \\
7.25 \\
7.15\end{array}$ & $\begin{array}{l}5.35 \\
5.35 \\
5.15 \\
4.9\end{array}$ & $\begin{array}{l}5.1 \\
5.5 \\
5.4 \\
5.35\end{array}$ & $\begin{array}{l}4.4 \\
4.65 \\
5.0 \\
5.05 \\
5.3\end{array}$ & $\begin{array}{l}7.6 \\
7.35 \\
6.95\end{array}$ & & $\begin{array}{l}5.05 \\
4.4 \\
4.35 \\
4.65 \\
4.7\end{array}$ & $\begin{array}{l}4.7 \\
4.45 \\
4.35 \\
4.45 \\
3.95\end{array}$ \\
\hline $\begin{array}{l}26 . . \\
27 . .\end{array}$ & $\begin{array}{l}5.3 \\
5.2 \\
5.35 \\
5.05 \\
5.2 \\
5.25\end{array}$ & $\begin{array}{l}5.1 \\
5.35 \\
5.05\end{array}$ & & $\begin{array}{l}6.75 \\
6.2 \\
6.55 \\
6.7 \\
6.75\end{array}$ & \begin{tabular}{l|}
7.2 \\
7.05 \\
6.95 \\
6.05 \\
6.65 \\
6.05
\end{tabular} & $\begin{array}{l}5.25 \\
5.2 \\
5.6 \\
5.15 \\
4.9\end{array}$ & $\begin{array}{l}5.25 \\
5.2 \\
4.95 \\
3.55 \\
4.7 \\
4.5\end{array}$ & $\begin{array}{l}5.15 \\
4.55 \\
4.3 \\
4.4 \\
4.7 \\
4.55\end{array}$ & $\begin{array}{l}6.8 \\
6.35 \\
6.0 \\
6.0 \\
5.6\end{array}$ & $\begin{array}{l}4.35 \\
3.85 \\
4.05 \\
5.15 \\
5.0 \\
5.1\end{array}$ & $\begin{array}{l}4.3 \\
5.0 \\
4.6 \\
4.5 \\
4.5\end{array}$ & $\begin{array}{l}3.75 \\
4.1 \\
4.95 \\
4.85 \\
4.55 \\
4.6\end{array}$ \\
\hline
\end{tabular}

$a$ Bridge was being repaired during March and April, 1907. 
Daily gage height, in feet, of Wisconsin River at Merrill, Wis., for 1907 and 1908 -Continued.

\begin{tabular}{|c|c|c|c|c|c|c|c|c|c|c|c|c|}
\hline Day. & Jan. & Feb. & Mar. & Apr. & May. & June. & July. & Aug. & Sept. & Oet. & Nov. & Dec. \\
\hline $\begin{array}{c}1908 . \\
1 \ldots \ldots \ldots \\
2 \ldots \ldots \ldots \\
3 \ldots \ldots \\
4 \ldots \ldots \\
5 \ldots \ldots \ldots \\
\ldots \ldots \ldots\end{array}$ & $\begin{array}{l}4.55 \\
4.75 \\
4.9 \\
4.8 \\
4.45\end{array}$ & $\begin{array}{l}4.8 \\
4.65 \\
4.3 \\
4.45 \\
4.7\end{array}$ & $\begin{array}{l}4.6 \\
4.4 \\
4.75 \\
4.7 \\
4.85\end{array}$ & $\begin{array}{l}5.15 \\
4.85 \\
5.1 \\
4.9 \\
5.15\end{array}$ & $\begin{array}{l}8.15 \\
7.85 \\
7.8 \\
7.45 \\
7.3\end{array}$ & $\begin{array}{l}6.75 \\
6.8 \\
6.6 \\
6.35 \\
6.0\end{array}$ & $\begin{array}{l}4.8 \\
5.6 \\
5.05 \\
4.9 \\
5.75\end{array}$ & $\begin{array}{l}5.2 \\
4.95 \\
4.45 \\
4.5 \\
4.65\end{array}$ & $\begin{array}{l}4.2 \\
3.9 \\
\text { 4. } 15 \\
4.35 \\
4.4\end{array}$ & $\begin{array}{l}5.6 \\
5.2 \\
5.05 \\
4.95 \\
4.95\end{array}$ & $\begin{array}{l}3.7 \\
4.5 \\
4.55 \\
4.6 \\
4.6\end{array}$ & $\begin{array}{l}4.55 \\
4.6 \\
3.75 \\
4.55 \\
4.65\end{array}$ \\
\hline $\begin{array}{r}6 \ldots \ldots \ldots \\
7 \ldots \ldots \ldots \\
8 \ldots \ldots \ldots \\
9 \ldots \ldots \ldots \ldots \\
10 \ldots \ldots \ldots \ldots \\
\ldots \ldots \ldots\end{array}$ & $\begin{array}{l}4.4 \\
4.75 \\
4.65 \\
4.55 \\
4.9\end{array}$ & $\begin{array}{l}4.55 \\
4.6 \\
4.6 \\
4.8 \\
4.6\end{array}$ & $\begin{array}{l}5.0 \\
4.9 \\
4.5 \\
4.5 \\
4.35\end{array}$ & $\begin{array}{l}5.5 \\
5.9 \\
6.05 \\
6.45 \\
6.7\end{array}$ & $\begin{array}{l}7.2 \\
6.9 \\
6.4 \\
6.45 \\
6.55\end{array}$ & $\begin{array}{l}5.5 \\
5.65 \\
6.95 \\
7.1 \\
7.15\end{array}$ & $\begin{array}{l}6.7 \\
7.85 \\
7.6 \\
7.2 \\
6.75\end{array}$ & $\begin{array}{l}4.6 \\
5.2 \\
5.65 \\
4.85 \\
4.75\end{array}$ & $\begin{array}{l}4.1 \\
4.3 \\
5.9 \\
6.1 \\
4.55\end{array}$ & $\begin{array}{l}\text { 4. } 55 \\
\text { 4. } 8 \\
\text { 4. } 75 \\
\text { 4. } 7 \\
4.75\end{array}$ & $\begin{array}{l}4.45 \\
4.2 \\
4.55 \\
7.35 \\
5.35\end{array}$ & $\begin{array}{l}4.55 \\
4.5 \\
4.35 \\
4.35 \\
4.55\end{array}$ \\
\hline $\begin{array}{l}11 \ldots \ldots \ldots \\
12 \ldots \ldots \ldots \\
13 \ldots \ldots \ldots \\
14 \ldots \ldots \\
15 \ldots \ldots \ldots\end{array}$ & $\begin{array}{l}4.45 \\
4.65 \\
4.85 \\
4.65 \\
4.7\end{array}$ & $\begin{array}{l}4.7 \\
4.85 \\
4.85 \\
5.0 \\
4.85\end{array}$ & $\begin{array}{l}4.4 \\
4.4 \\
4.75 \\
4.6 \\
4.8\end{array}$ & $\begin{array}{l}6.65 \\
6.95 \\
7.25 \\
7.55 \\
8.1\end{array}$ & $\begin{array}{l}6.45 \\
6.15 \\
5.65 \\
6.5 \\
6.3\end{array}$ & $\begin{array}{l}6.8 \\
6.5 \\
6.7 \\
6.6 \\
6.5\end{array}$ & $\begin{array}{l}6.1 \\
5.7 \\
4.35 \\
4.85 \\
4.75\end{array}$ & $\begin{array}{r}4.7 \\
4.3 \\
3.6 \\
4.4 \\
3.6\end{array}$ & $\begin{array}{l}3.95 \\
4.05 \\
3.95 \\
4.1 \\
4.55\end{array}$ & $\begin{array}{l}\text { 4. } 6 \\
4.45 \\
4.75 \\
4.6 \\
4.3\end{array}$ & $\begin{array}{l}4.8 \\
4.4 \\
4.05 \\
4.05 \\
3.95\end{array}$ & $\begin{array}{l}4.45 \\
4.45 \\
4.25 \\
4.3 \\
4.6\end{array}$ \\
\hline $\begin{array}{l}16 \ldots \ldots \ldots \\
17 \ldots \ldots \ldots \\
18 \ldots \ldots \ldots \\
19 \ldots \ldots \ldots \ldots \\
20 \ldots \ldots \ldots \ldots\end{array}$ & $\begin{array}{l}4.6 \\
4.7 \\
4.7 \\
4.75 \\
4.75\end{array}$ & $\begin{array}{l}4.85 \\
4.5 \\
4.8 \\
4.85 \\
4.9\end{array}$ & $\begin{array}{l}4.85 \\
4.8 \\
4.85 \\
4.75 \\
4.9\end{array}$ & $\begin{array}{l}8.15 \\
7.6 \\
7.75 \\
7.25 \\
7.15\end{array}$ & $\begin{array}{l}6.4 \\
6.2 \\
6.5 \\
6.5 \\
6.8\end{array}$ & $\begin{array}{l}6.9 \\
6.85 \\
5.7 \\
5.8 \\
5.75\end{array}$ & $\begin{array}{l}4.7 \\
4.55 \\
4.75 \\
5.1 \\
5.3\end{array}$ & $\begin{array}{l}4.0 \\
3.5 \\
4.1 \\
4.2 \\
4.5\end{array}$ & $\begin{array}{l}5.05 \\
3.05 \\
3.1 \\
3.2 \\
3.05\end{array}$ & $\begin{array}{l}\text { 4. } 1 \\
\text { 4. } 25 \\
\text { 4. } 5 \\
\text { 4. } 45 \\
\text { 4. } 6\end{array}$ & $\begin{array}{l}4.25 \\
4.4 \\
3.75 \\
2.8 \\
2.7\end{array}$ & $\begin{array}{l}4.9 \\
4.85 \\
4.8 \\
4.85 \\
4.1\end{array}$ \\
\hline $\begin{array}{l}21 \ldots \ldots \ldots \\
22 \ldots \ldots \ldots \ldots \\
23 \ldots \ldots \ldots \\
24 \ldots \ldots \ldots \\
25 \ldots \ldots \ldots \ldots\end{array}$ & $\begin{array}{l}4.35 \\
4.5 \\
4.55 \\
4.75 \\
4.4\end{array}$ & $\begin{array}{l}5.2 \\
4.6 \\
4.7 \\
4.5 \\
4.75\end{array}$ & $\begin{array}{l}4.9 \\
4.8 \\
5.05 \\
5.05 \\
4.95\end{array}$ & $\begin{array}{l}7.2 \\
7.2 \\
7.25 \\
7.3 \\
7.65\end{array}$ & $\begin{array}{l}6.3 \\
7.0 \\
7.1 \\
7.35 \\
7.15\end{array}$ & $\begin{array}{l}5.6 \\
5.25 \\
5.0 \\
5.75 \\
5.9\end{array}$ & $\begin{array}{l}5.4 \\
5.65 \\
5.75 \\
5.2 \\
5.5\end{array}$ & $\begin{array}{l}5.05 \\
5.15 \\
4.8 \\
4.3 \\
2.9\end{array}$ & $\begin{array}{l}3.1 \\
2.85 \\
2.85 \\
2.85 \\
2.9\end{array}$ & $\begin{array}{l}4.6 \\
4.25 \\
4.6 \\
4.55 \\
4.3\end{array}$ & $\begin{array}{l}3.85 \\
3.15 \\
3.05 \\
3.15 \\
3.2\end{array}$ & $\begin{array}{l}4.75 \\
4.85 \\
4.75 \\
4.8 \\
4.55\end{array}$ \\
\hline $\begin{array}{l}26 \ldots \ldots \ldots \\
27 \ldots \ldots \ldots \\
28 \ldots \ldots \ldots \\
29 \ldots \ldots \ldots \\
30 \ldots \ldots \\
31 \ldots \ldots \\
\ldots \ldots\end{array}$ & $\begin{array}{l}4.2 \\
4.7 \\
4.45 \\
4.55 \\
4.65 \\
4.7\end{array}$ & \begin{tabular}{l}
4.7 \\
5.05 \\
4.8 \\
4.7 \\
$\cdots \cdots$ \\
\hdashline$\cdots$
\end{tabular} & $\begin{array}{l}5.0 \\
4.85 \\
4.85 \\
4.8 \\
4.85 \\
5.1\end{array}$ & $\begin{array}{l}8.2 \\
8.45 \\
8.9 \\
9.25 \\
8.7 \\
-\cdots .\end{array}$ & $\begin{array}{l}6.95 \\
6.9 \\
6.95 \\
6.65 \\
6.7 \\
6.6\end{array}$ & $\begin{array}{l}5.85 \\
5.85 \\
4.9 \\
4.5 \\
5.35 \\
\cdots \cdots\end{array}$ & $\begin{array}{l}4.65 \\
4.75 \\
4.95 \\
5.15 \\
5.0 \\
5.25\end{array}$ & $\begin{array}{l}3.8 \\
4.5 \\
4.45 \\
3.95 \\
4.2 \\
4.45\end{array}$ & $\begin{array}{l}2.45 \\
2.8 \\
3.15 \\
5.1 \\
5.7\end{array}$ & $\begin{array}{l}4.3 \\
4.6 \\
5.2 \\
4.85 \\
4.95 \\
4.8\end{array}$ & $\begin{array}{l}5.1 \\
5.05 \\
5.1 \\
4.55 \\
4.65 \\
\cdots \cdots\end{array}$ & $\begin{array}{l}4.5 \\
4.5 \\
5.05 \\
5.2 \\
4.95 \\
4.6\end{array}$ \\
\hline
\end{tabular}

Rating tables for Wisconsin River at Merrill, Wis.

FOR 1907.

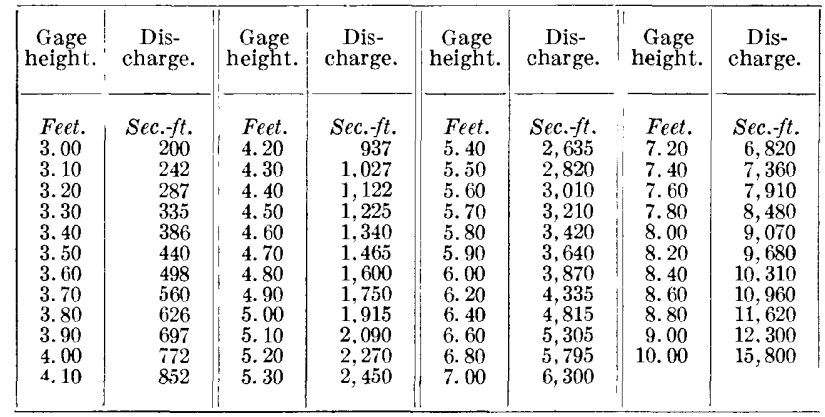

NotE.-The above table is not applicable for ice or obstructed-channel conditions. It is based on discharge measurements made during 1904 to 1907 . On account of repairs to the bridge, piers, and abutments, and $\log$ jams above and below the section, the above table may be 20 per cent in error for low gage heights and about 10 per cent for high gage heights.

FOR 1908.

\begin{tabular}{|r|r|r|r|r|r|r|r|}
\hline 2.40 & 80 & 3.20 & 340 & 4.00 & 850 & 4.80 & 1,730 \\
2.50 & 100 & 3.30 & 390 & 4.10 & 940 & 4.90 & 1,870 \\
2.60 & 120 & 3.40 & 440 & 4.20 & 1,030 & 5.00 & 2,010 \\
2.70 & 150 & 3.50 & 500 & 4.30 & 1,130 & 5.10 & 2,160 \\
2.80 & 180 & 3.60 & 560 & 4.40 & 1,240 & 5.20 & 2,310 \\
2.90 & 210 & 3.70 & 630 & 4.50 & 1,350 & 5.30 & 2,470 \\
3.00 & 250 & 3.80 & 700 & 4.60 & 1,470 & 5.40 & 2,640 \\
3.10 & 290 & 3.90 & 770 & 4.70 & 1,600 & 5.50 & 2,820 \\
\hline
\end{tabular}

NotE.-The above table is not applicable for ice or obstructed-channel conditions. It is based on disecharge measurements made during 1905 to 1908 , and is fairly well defined between gage heights 4.5 feet and 8.5 feet. A bove gage height 5.5 feet it is the same as the 1907 tahle. 
Monthly discharge of Wisconsin River at Merrill, Wis., for 1907 and 1908.

[Drainage area, 2,630 square miles.]

\begin{tabular}{|c|c|c|c|c|c|c|}
\hline \multirow{2}{*}{ Month. } & \multicolumn{4}{|c|}{ Discharge in second-feet. } & \multirow{2}{*}{$\begin{array}{l}\text { Run-off } \\
\text { (depth in } \\
\text { inches on } \\
\text { drainage } \\
\text { area). }\end{array}$} & \multirow{2}{*}{$\begin{array}{l}\text { Aceu- } \\
\text { racy. }\end{array}$} \\
\hline & Maximum. & Minimum. & Mean. & $\begin{array}{l}\text { Per } \\
\text { square } \\
\text { inile. }\end{array}$ & & \\
\hline $190 \pi$. & & & & & & \\
\hline January............... & 3,010 & 1,600 & 2,140 & 0.814 & 0.94 & B. \\
\hline February $\ldots \ldots \ldots \ldots \ldots \ldots \ldots$ & 2,540 & 1.830 & 2,130 & .810 & 84 & B. \\
\hline Mareh. & 6.600 & 1.460 & 2,690 & 1. 02 & 1.18 & B. \\
\hline April ... & 11,000 & 3.760 & 6.390 & 2. 43 & 2. 71 & B. \\
\hline$\ldots \ldots \ldots \ldots \ldots$ & 10,200 & 3.980 & 6,880 & 2. 62 & 3.02 & B. \\
\hline 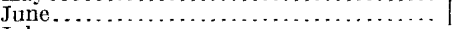 & 4,340 & 1.460 & 2,700 & 1.03 & 1.15 & B. \\
\hline July $\ldots \ldots \ldots \ldots \ldots \ldots \ldots \ldots \ldots \ldots$ & 3,760 & 469 & 2,690 & 1. $0^{2}$ & 1.18 & B. \\
\hline August. $\ldots \ldots \ldots \ldots \ldots \ldots \ldots \ldots \ldots \ldots$ & 2.920 & 626 & 1,370 & .521 & .60 & C. \\
\hline September . . . . & 13.000 & 335 & 3.710 & 1. 41 & 1.57 & B. \\
\hline October. . $\ldots \ldots \ldots \ldots \ldots \ldots \ldots \ldots$ & 3.320 & 662 & 2,000 & .760 & .88 & B. \\
\hline November. . . . . . . . . . & 2.360 & 221 & 1,370 & .521 & .58 & C. \\
\hline 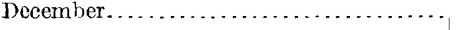 & 2,000 & 593 & 1,200 & .456 & .53 & C. \\
\hline The year.. & 13.000 & 221 & 2,940 & 1. 12 & 15.18 & \\
\hline 1908. & & & & & & \\
\hline January ............... & 1.870 & 1,030 & 1.510 & .574 & .66 & B. \\
\hline February $\ldots \ldots \ldots \ldots \ldots \ldots \ldots \ldots \ldots \ldots$ & 2,310 & 1,130 & 1,650 & .627 & .68 & B. \\
\hline 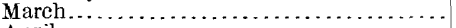 & 2.160 & 1.180 & 1.700 & .646 & .74 & B. \\
\hline 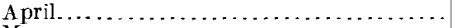 & 13.200 & 1.800 & 6.630 & 2. 52 & 2.81 & B. \\
\hline 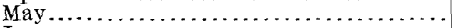 & 9,520 & 3,110 & 5,870 & 2. 23 & 2.57 & B. \\
\hline$\ldots \ldots \ldots \ldots \ldots$ & 6. 690 & 1,350 & 4.220 & 1. 60 & 1. 78 & B. \\
\hline July $\ldots \ldots \ldots \ldots \ldots \ldots \ldots \ldots \ldots \ldots \ldots \ldots$ & 8,620 & 1. 180 & 3.030 & 1. 15 & 1. 33 & B. \\
\hline 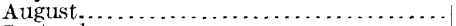 & 3,110 & 210 & $1,2,70$ & .521 & .60 & C. \\
\hline September $\ldots \ldots \ldots \ldots \ldots \ldots \ldots \ldots \ldots$ & 4,100 & 90 & 1,050 & .399 & .45 & C. \\
\hline 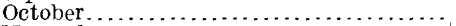 & 3.010 & 940 & 1,600 & .608 & .70 & 13. \\
\hline November.... & 7.220 & 150 & 1,340 & .510 & .57 & C. \\
\hline 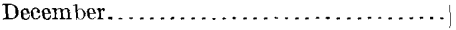 & 2,310 & 665 & 1,490 & .567 & .65 & C. \\
\hline The year... & 13,200 & 90 & 2,620 & .996 & 13.54 & \\
\hline
\end{tabular}

NOTE.-Discharge estimated by comparison with Ihinelander station for portions of Mareh and April, $190 \bar{t}$, when bridge was being repalred.

WISCONSIN RIVER NEAR NECEDAH, WIS.

This station, which is located at the highway bridge about 3 miles east of Necedah, Wis., was established December 2, 1902, to obtain data for studying water power, water supply, and pollution problems.

Big Roche a Cri Creck is tributary from the west about 5 miles below the station. The drainage area above the section is about 5,800 square miles.

The winter conditions are severe. Ice forms from 1 to 2 feet in thickness and lasts for about three months. Part of the river bottom is liable to shift in floods. But few discharge measurements have been made since 1906. The 1906 discharge table should not be used for later years.

The datum of the gage has remained unchanged. The gage heights are reliable and accurate.

Information in regard to this station prior to 1908 is contained in Bulletin XX of the Wisconsin Geological and Natural History Survey, entitled "Water powers of Wisconsin," by Leonard S. Smith. 
Discharge measurements of Wisconsin River near Necedah, Wis., in 1908.

\begin{tabular}{|c|c|c|c|c|c|}
\hline Date. & Ifydrographer. & Width. & $\begin{array}{l}\text { Area of } \\
\text { section. }\end{array}$ & $\begin{array}{c}\text { Gage } \\
\text { height. }\end{array}$ & $\begin{array}{c}\text { Dis- } \\
\text { charge. }\end{array}$ \\
\hline $\begin{array}{l}\text { January } 29 a \ldots \\
\text { Felruary } 19 h \ldots \\
\text { July } 7 \ldots \ldots \ldots\end{array}$ & $\begin{array}{l}\text { G. A. Gray } \\
\ldots \text {. do } \ldots . . . \\
\ldots \text {. do } \ldots . . .\end{array}$ & \begin{tabular}{r|} 
Feet. \\
276 \\
273 \\
309
\end{tabular} & $\begin{array}{r}S q . f t . \\
1,550 \\
1,400 \\
2.610\end{array}$ & $\begin{array}{l}\text { Fect. } \\
5.15 \\
5.70 \\
6.12\end{array}$ & $\begin{array}{r}\text { Sec. }-f t \\
1,970 \\
2,280 \\
5,570\end{array}$ \\
\hline
\end{tabular}

a Ice measurement; average thickness of ice 0.9 foot

$b$ Iee measurement; average thickness of ice 1.1 feet.

Daily gage height, in feet, of W'isconsin River near Necedah, Wis., for 190\% and 1908.

[W. F. Bingham and W. F. IIuber, observers.]

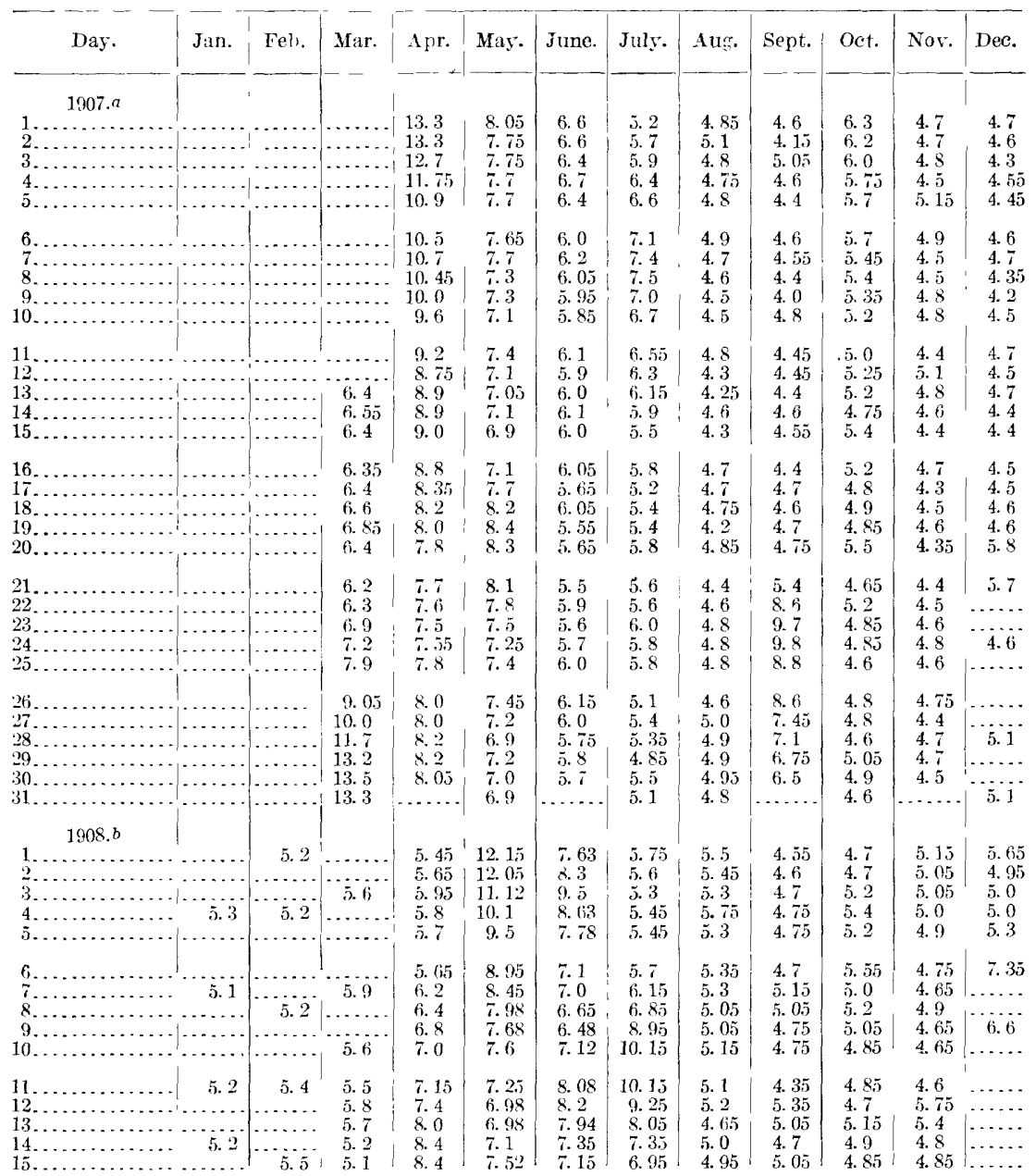

a River was frozen January 1 to March 12, and December 22 to 31, 1907. Gage heights during the frozen period taken to the water surface.

$b$ lce conditions, Ianuary 1 to March 11, and Decemlier 9 to 31, 1908. Gage readings during the frozen periods taken to water surface. 
Daily gage height, in feet, of Wisconsin River near Necedah, Wis., for 1907 and 1908-Con.

\begin{tabular}{|c|c|c|c|c|c|c|c|c|c|c|c|c|}
\hline Day. & Jan. & Feb. & Mar. & Apr. & May. & June. & July. & Aug. & Sept. & Oct. & Nov. & Dec. \\
\hline $\begin{array}{r}1908 . \\
16 \ldots \ldots \ldots \\
17 \ldots \ldots \ldots \\
18 \ldots \ldots \ldots \\
19 \ldots \ldots \ldots \\
20 \ldots \ldots \ldots\end{array}$ & 5. 2 & 5.7 & $\begin{array}{l}4.95 \\
5.4 \\
5.5 \\
5.4 \\
5.4\end{array}$ & $\begin{array}{l}8.8 \\
8.9 \\
9.15 \\
8.9 \\
8.5\end{array}$ & $\begin{array}{l}7.6 \\
7.62 \\
7.75 \\
7.88 \\
7.75\end{array}$ & $\begin{array}{l}7.15 \\
7.08 \\
6.8 \\
6.6 \\
6.45\end{array}$ & $\begin{array}{l}6.45 \\
6.1 \\
6.0 \\
5.95 \\
5.55\end{array}$ & \begin{tabular}{l|}
5.0 \\
4.9 \\
4.85 \\
4.85 \\
4.75
\end{tabular} & $\begin{array}{l}4.55 \\
4.35 \\
4.55 \\
4.65 \\
4.95\end{array}$ & $\begin{array}{l}\text { 4. } 8 \\
\text { 4. } 8 \\
4.7 \\
\text { 4. } 35 \\
4.9\end{array}$ & $\begin{array}{l}\text { 4. } 6 \\
\text { 4. } 4 \\
4.3 \\
4.6 \\
4.9\end{array}$ & $\begin{array}{c}6.4 \\
\ldots \ldots . \\
\cdots \cdots \\
\cdots \ldots . . \\
\ldots . . \\
\end{array}$ \\
\hline $\begin{array}{l}21 \ldots \\
22 \ldots \\
23 \ldots \\
24 \ldots \\
25 \ldots \\
25\end{array}$ & 5.3 & 5.7 & $\begin{array}{l}5.3 \\
5.1 \\
4.9 \\
5.2 \\
5.2\end{array}$ & $\begin{array}{l}8.2 \\
8.2 \\
8.1 \\
7.8 \\
7.8\end{array}$ & $\begin{array}{l}7.6 \\
7.9 \\
7.9 \\
8.28 \\
9.1\end{array}$ & $\begin{array}{l}6.18 \\
6.1 \\
6.1 \\
6.05 \\
5.9\end{array}$ & $\begin{array}{l}5.95 \\
5.65 \\
5.85 \\
5.9 \\
5.85\end{array}$ & $\begin{array}{l}4.9 \\
4.9 \\
4.75 \\
5.35 \\
4.8\end{array}$ & $\begin{array}{l}\text { 4. } 45 \\
\text { 4. } 9 \\
\text { 4. } 65 \\
\text { 4. } 45 \\
4.6\end{array}$ & $\begin{array}{l}\text { 4. } 5 \\
4.3 \\
\text { 4. } 7 \\
4.6 \\
4.75\end{array}$ & $\begin{array}{l}4.75 \\
4.5 \\
4.65 \\
4.25 \\
4.3\end{array}$ & $\begin{array}{r}\cdots \\
6.2 \\
\cdots \ldots \\
\cdots \ldots\end{array}$ \\
\hline $\begin{array}{l}26 . \\
27 . \\
28 . \\
29 . \\
30 . \\
31 .\end{array}$ & 5.1 & 5.7 & $\begin{array}{l}5.5 \\
6.1 \\
5.9 \\
5.9 \\
5.7 \\
5.8\end{array}$ & $\begin{array}{r}7.7 \\
8.7 \\
9.9 \\
10.9 \\
11.5\end{array}$ & $\begin{array}{l}9.1 \\
8.65 \\
8.24 \\
8.28 \\
8.15 \\
7.78\end{array}$ & $\begin{array}{l}5.75 \\
6.15 \\
6.1 \\
5.8 \\
5.8\end{array}$ & $\begin{array}{l}5.85 \\
5.65 \\
5.95 \\
5.7 \\
5.7 \\
5.25\end{array}$ & $\begin{array}{l}5.2 \\
4.85 \\
4.75 \\
4.75 \\
4.8 \\
5.1\end{array}$ & $\begin{array}{l}\text { 4. } 4 \\
\text { 4. } 5 \\
\text { 4. } 4 \\
\text { 4. } 55 \\
\text { 4. } 45\end{array}$ & $\begin{array}{l}4.6 \\
4.7 \\
4.6 \\
4.7 \\
4.9 \\
5.1\end{array}$ & $\begin{array}{l}4.25 \\
4.3 \\
4.55 \\
5.5 \\
5.75\end{array}$ & {$\left[\begin{array}{c}\cdots \cdots \\
\cdots \cdots \\
\cdots \\
6.0\end{array}\right.$} \\
\hline
\end{tabular}

WAPSIPINICON RIVER DRAINAGE BASIN.

\section{DESCRIPTION.}

The drainage basin of Wapsipinicon River lies almost entirely in the northwestern part of Iowa. The river rises a few miles north of the Minnesota state line in Mower County, flows southeastward, and joins the Mississippi along the southern boundary of Clinton County, Iowa, about 10 miles below the city of Clinton, Iowa. The length of the river, not following the numerous bends, is about 220 miles, and the total length by stream course is not far from 300 miles. The drainage basin is long and narrow, being approximately 185 miles in length and 14 miles in average width.

The tributaries are all small. The more important are the West, Middle, and East branches, which unite above Tripoli in Bremer County, and Little Wapsipinicon River and Buffalo Creek, which enter from the east.

The basin is underlain by limestones, which have been thinly covered with glacial drift. The surface of the country is a gently undulating prairie, and the valley of the river is narrow with gently sloping sides. Near Anamosa the valley is quite narrow and picturesque; the bed and banks are rocky, the banks rising to a good height and in places running abruptly up into bluffs.

The elevation of the sources of the river is about 1,250 feet; at Independence the elevation is about 900 feet; at Stone City about 780 feet; at the mouth the elevation is 560 feet.

The drainage basin contains no forested areas. The mean annual rainfall is about 32 inches. The winters are severe, snowfall is heavy, and ice forms from 1 to 2 feet in thickness and lasts about three inonths. 
Storage possibilities have not been investigated, but the topography of the basin is not favorable and the high value of the land for farming would undoubtedly prohibit the construction of reservoirs.

A number of fair power sites are found along the river, some of which have been developed. Conditions are favorable for building dams, as the banks are as a rule firm, and rock forms the river bed in many places. The geological formation tends to keep the flow of the river fairly uniform and steady, as the glacial drift is thin, and the rainfall reaches the river through springs at the rock outcrops.

One gaging station has been maintained in this drainage basin:

Wapsipinicon River at Stone City, Iowa, 1903 to 1908.

WAPSIPINICON RIVER AT STONE CITY, IOWA.

This station is located at Stone City, Iowa, at the highway bridge, a short distance above the Chicago, Milwaukee, and St. Paul Railroad bridge. It was established August 19, 1903, to obtain data for use in studying water power, water supply, and pollution problems.

Buffalo Creek is tributary from the east about 4 miles below the station.

The winter conditions are severe, ice forming from 1 to 2 feet in thickness and lasting about three months.

The records at this station are furnished by Frank Dearborn.

December 4, 1906, the gage datum was changed by an unknown amount, due to repairs made on the bridge.

Gage-height and monthly-discharge tables are withheld pending further investigation.

\section{ROCK RIVER DRAINAGE BASIN.}

DESCRIPTION.

The drainage basin of Rock River lies in the southeastern part of Wisconsin and in the northwestern part of Illinois. The river rises in the southeastern part of Fond du Lac County in Wisconsin, flows in a slight southwesterly direction across the Illinois state line, and at Rockford, Ill., turns more to the southwest and joins Mississippi River about 6 miles below the city of Rock Island, Ill. The total length of the river is about 286 miles. The total drainage area is about 11,000 square miles, of which 5,650 square miles is in Wisconsin and about 5,350 square miles in Illinois.

The more important tributaries beginning at the source of Rock River are East Branch of Rock River, Oconomowoc, Bark, Turtle Creek, Kiskaukee, Kyte, and Green rivers on the left or east bank; and West Branch of Rock River, Crawfish, Catfish, and Pecatonica rivers, and Rock Creek on the right or west bank. 
The drainage basin is irregular in shape, being about 175 miles in length, and about 85 miles in greatest width. In the upper part of its course the river flows rather toward the eastern side of the basin, at the Illinois state line it approaches the center, and in its lower course it flows decidedly near the western boundary. The rocks underlying this basin are limestones and shales, which have been in large part covered by the drift and morainic débris of glacial times, and the soils vary with the geologic formations on which they rest.

The topography in the Illinois portion of the drainage area is an undulating, semiprairie region; in Wisconsin the surface is moderately hilly, elevations ranging from 750 feet where the river enters the State of Illinois to 1,100 feet on the crests of the Kettle Range. The rise from the interior of the valley is gradual, and few of the hill tops are more than 100 feet above the intervening valleys. The low, uneven topography has led to the formation of an intricate tributary system with numerous spring-fed lakes. These lakes occur chiefly in an eastern and western group, the eastern comprising about 20 lakes with an aggregate area of 11 square miles, and the western including 5 lakes with a total area of 13 square miles. The elevation of the source of the river is approximately 1,000 feet above sea level; at Horicon the elevation is 858 feet; at the state line it is 731 feet, and at the mouth of the river 540 feet. The average slope is a little over 1 foot per mile.

The forested area, according to L. S. Smith, of Madison, Wis., is about 30 per cent in that part of the drainage area in Wisconsin. The forested area in Illinois is probably less than in Wisconsin, as the State has been longer settled.

The mean annual rainfall is about 35 inches. The winters in the northern part of this drainage area are comparatively severe, snowfall is heavy, and ice forms a foot or more in thickness on the streams. In the lower part of the drainage basin the winters are somewhat milder.

The basin affords good opportunities for storage, but the value of the land that would be flooded by reservoirs prohibits their construction. Lake Koshkoning, an expansion of Rock River, 23 square miles in extent, is the only body of water now controlled in the interests of manufacturing.

Although the average slope of Rock River is small, sites for water power are numerous, as in general good foundations for dams may be found. A great many of the power sites are fully or partly developed, but there are still undeveloped power sites on the main stream and its tributaries. The power sites on the tributaries, with few exceptions, have small fall, and many developed sites have been abandoned because of the greater value of the submerged land for farms. 
The following gaging stations have been maintained in this drainage basin:

Rock River above mouth of Pecatonica River at Rockton, Ill., 1903.

Rock River below mouth of Pecatonica River at Rockton, Ill., 1903-1908.

Rock River near Nelson, IIl., 1906.

Rock River at Sterling, Ill., 1905-6.

Catfish River at Madison, Wis., 1902-3.

Lake Mendota at Madison, IVis., 1902-3.

ROCK RIVER AT ROCKTON, ILL.

This station, which is located at the highway bridge at Rockton, Ill,, was established May 13, 1903, to obtain data for studying water power, water supply, and pollution problems.

Pecatonica River is tributary from the west about three-fourths of a mile above the station. A dam and power plant above the station may modify the flow somewhat during periods of low water. The winters in this vicinity are comparatively mild; ice forms on the river, but open places generally exist at the section. Ice jams are frequent below the station and cause backwater at the gage.

On October 1, 1906, the gage datum was changed by an unknown amount, which approximates about 1 foot.

The monthly discharges for October, November, and December, 1906, were determined from a rating curve applicable to gage heights based on the original datum, and hence are considerably in error. When a new rating curve is developed these will be revised.

Discharge measurements of Rock River at Rockton, Ill., in $190 \%$ and 1908.

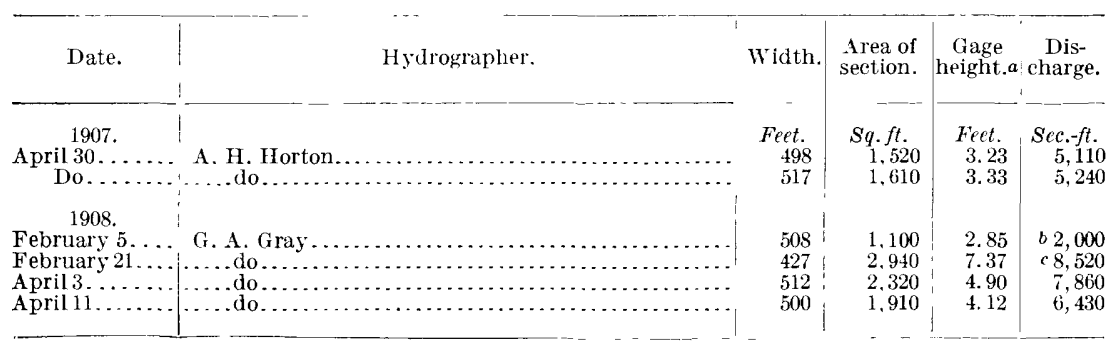

a New gage datum.

$b$ Ice conditions; average thickness of ice, 0.8 foot.

$c$ Ice gorge below gage. 
Daily gage height, in feet, of Rock River at Rockton, Ill., for 1907 and 1908.

[O. T. Bartholemew, observer.]

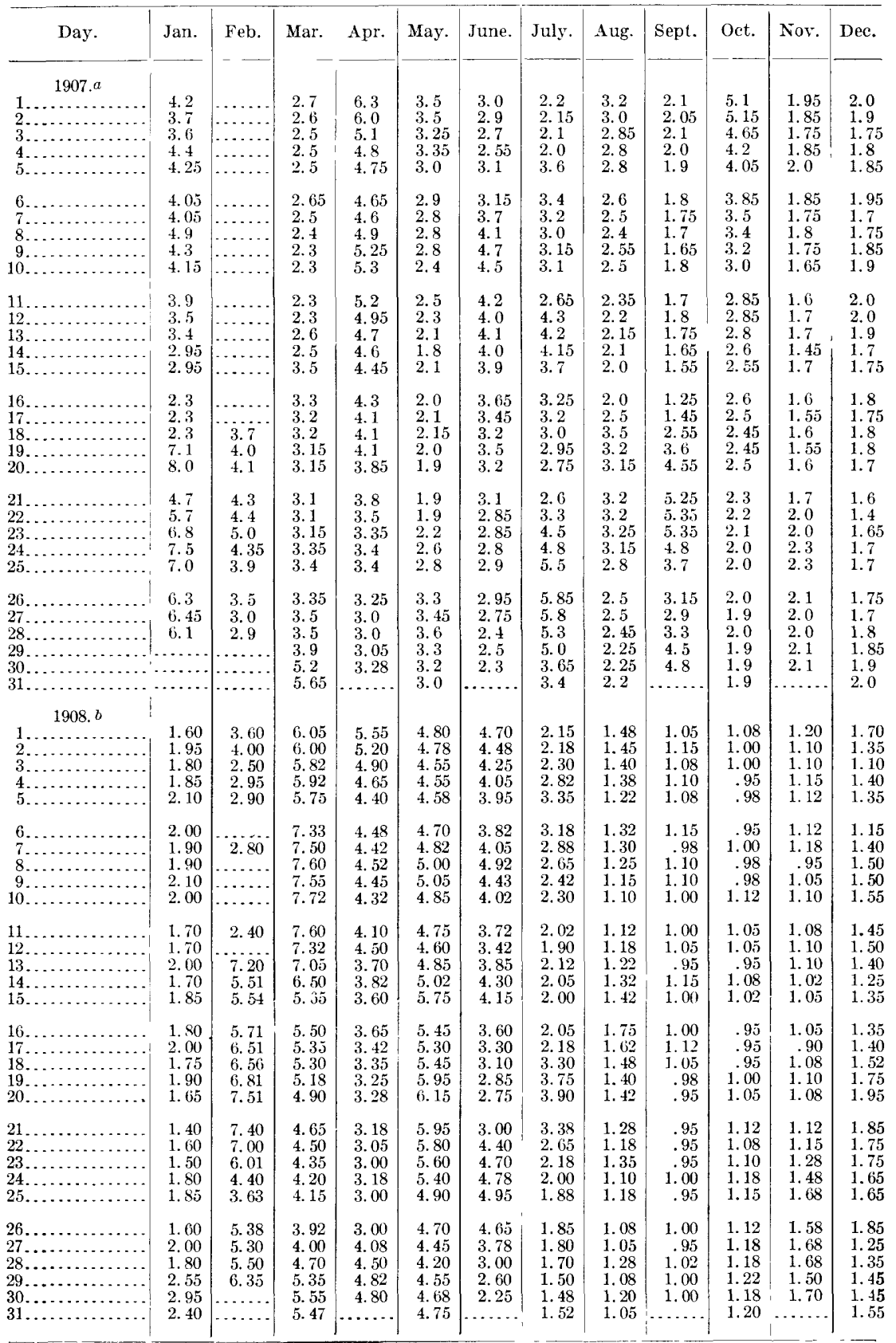

$a$ Stream frozen about January 29 to February 17,1907 .

$b$ Ice conditions probably prevailed from about the last of January to the middle of February, 1908. 


\section{IOWA RIVER DRAINAGE BASIN.}

DESCRIPTION.

The drainage basin of Iowa River and its tributary, Cedar River, occupies the north central and southeast central part of the State of Iowa, and parts of Freeborn, Dodge, and Mower counties in southern Minnesota. The river rises in the northern part of Hancock County, Iowa, flows southeastward, and joins Mississippi River in the southeastern part of Louisa County. The length of Iowa River is about 270 miles, not following the bends. The total drainage area is about 12,400 square miles. Cedlar River, which is called a tributary of the Iowa, although its drainage is much the larger, rises in the southern part of Dodge County, in southern Minnesota, flows southeastward into Iowa, and continues in that direction until it reaches Moscow, in the northern part of Muscatine County, where it makes an abrupt turn to the southwest and joins the Iowa in Louisa County. The river is about 260 miles long, not following the bends. In its upper course it is called Red Cedar River. The drainage area above its mouth is about 7,600 square miles. It is the only important tributary of the Iowa. The principal tributaries of Cedar River are: Little Cedar, Shell Rock, and West Fork of Red Cedar rivers, all of which are tributary above Waterloo.

The drainage basin of Iowa River proper is long and narrow. The river rises in a broad, flat, or slightly undulating drift region, and the first rock exposed in its valley is the limestone that forms the rocky banks of the stream in the southwestern corner of Franklin County; from this point to its confluence with the Cedar, the river crosses a succession of sedimentary rocks. The drift which covers this region is well supplied with springs which help to maintain the flow of the stream. The surface of the surrounding country is a gently undulating prairie.

The drainage basin of Cedar River is underlain throughout its entire course by limestones which are thinly covered with glacial drift. Rock is exposed at many places along the main stream and its tributaries. The valleys of the upper tributaries are narrow, with gently sloping sides; below the mouth of the Shell Rock the valley is broad and shallow, and is separated from the uplands by distinctly defined borders. The surface of the country is a gently undulating prairie, apparently level in some sections. The upper basin is about 50 miles wide, but the lower is much narrower, and at one point below Cedar Rapids it measures only 8 or 9 miles across.

At the headwaters of both Iowa and Cedar rivers are a few lakes, ranging in area from 2 to 10 square miles.

The elevation of the sources of Iowa River is about 1,250 feet above sea level; at Iowa City the elevation is 670 feet; at the mouth of the 
Cedar it is 565 feet, and at the junction with the Mississippi the elevation is about 522 feet. The elevation of the sources of Cedar River is about 1,300 feet; at Waterloo about 820 feet; at Cedar Rapids about 725 feet, and at the mouth about 565 feet.

The basin contains no large forested areas. The mean annual rainfall is about 32 inches. The winters are severe, especially in the upper part of the basin. The fall of snow is comparatively heavy, and ice forms to considerable thickness on the streams and lasts for three to four months.

Storage possibilities have not been investigated; it may be possible to make storage reservoirs at the lakes at the headwaters of both Cedar and Iowa rivers, but the overflow damages would undoubtedly prohibit their construction.

Iowa and Cedar rivers are by far the most important streams in Iowa for water power. Power sites of small head are numerous, and a number of them have been developed. Those on Cedar River are more important than those on the Iowa. The numerous rock outcrops furnish good foundations for dams. The flow of the streams sustained is kept up by numerous springs, but during long-continued droughts the flow becomes very low.

The following gaging stations have been maintained in this drainage basin:

Iowa River at Marshalltown, Iowa, 1903.

Iowa River at Iowa City, Iowa, 1903-1906.

Red Cedar River at Janesville, Iowa, 1905-6.

Cedar River at Cedar Rapids, Iowa, 1903-1908.

\section{CEDAR RIVER AT CEDAR RAPIDS, IOWA.}

This station, which is located on the First Avenue Bridge at Cedar Rapids, Iowa, was established October 26, 1902, to obtain data for studying water power, water supply, and pollution problems.

The gage is located about one-half mile below the First Avenue Bridge. Discharge measurements previous to 1903 were made from a cable immediately above the gage. There is a large island in the river about 500 feet below the section.

The gage is located where the current is swift and the river rarely freezes clear across, ice forming only along the shores. The relation between gage height and discharge is probably therefore very little affected by ice. A dam and power plant above the station may modify the flow to some extent in low water.

The gage is an inclined timber set on posts in the bank of the river. The elevation of the gage has not been checked for a number of years, but it is thought that the datum has remained unchanged. The records and estimates of the discharge at this station are considered excellent. 
Daily gage height, in feet, of Cedar River at Cedır Rapids, Iowa, for 1907 and 1908.

[R. S. Toogood, observer.]

\begin{tabular}{|c|c|c|c|c|c|c|c|c|c|c|c|c|}
\hline Day. & Jan. & Feb. & Mar. & $\Delta \mathrm{pr}$ & May. & June. & July. & Aug. & Sept. & Oct. & Nov. & Dec. \\
\hline $\begin{array}{r}1907, a \\
1 \ldots \ldots \ldots \\
2 \ldots \ldots \ldots\end{array}$ & $\begin{array}{l}4.15 \\
4.25 \\
4.65 \\
4.7 \\
4.65\end{array}$ & $\begin{array}{l}4.4 \\
4.55 \\
4.45 \\
4.3 \\
4.25\end{array}$ & $\begin{array}{l}4.55 \\
4.75 \\
4.8 \\
5.95 \\
6.4\end{array}$ & $\begin{array}{l}5.05 \\
5.0 \\
5.0 \\
4.85 \\
4.6\end{array}$ & $\begin{array}{l}3.55 \\
3.6 \\
3.65 \\
3.6 \\
3.55\end{array}$ & $\begin{array}{l}3.5 \\
3.45 \\
3.55 \\
3.65 \\
3.75\end{array}$ & $\begin{array}{l}4.15 \\
4.05 \\
4.05 \\
4.4 \\
4.4\end{array}$ & $\begin{array}{l}4.85 \\
4.6 \\
4.4 \\
4.3 \\
4.25\end{array}$ & $\begin{array}{l}4.95 \\
4.8 \\
4.55 \\
4.3 \\
4.15\end{array}$ & $\begin{array}{l}4.0 \\
4.6 \\
4.95 \\
5.15 \\
4.7\end{array}$ & $\begin{array}{l}3.45 \\
3.45 \\
3.45 \\
3.4 \\
3.4\end{array}$ & $\begin{array}{l}3.45 \\
3.4 \\
3.3 \\
3.25 \\
3.15\end{array}$ \\
\hline $\begin{array}{r}6 . . \\
7 . . \\
8 . . \\
9 . . \\
10 .\end{array}$ & $\begin{array}{l}4.55 \\
4.7 \\
4.8 \\
4.65 \\
4.45\end{array}$ & $\begin{array}{l}4.4 \\
4.2 \\
4.15 \\
4.05 \\
4.0\end{array}$ & $\begin{array}{l}6.55 \\
5.6 \\
5.3 \\
5.0 \\
4.75\end{array}$ & $\begin{array}{l}4.4 \\
4.3 \\
4.25 \\
4.2 \\
4.15\end{array}$ & $\begin{array}{l}3.55 \\
3.5 \\
3.5 \\
3.45 \\
3.4\end{array}$ & $\begin{array}{l}3.85 \\
4.1 \\
4.25 \\
4.4 \\
4.85\end{array}$ & $\begin{array}{l}4.6 \\
5.05 \\
4.7 \\
5.1 \\
5.4\end{array}$ & $\begin{array}{l}4.65 \\
5.0 \\
5.1 \\
4.6 \\
4.85\end{array}$ & \begin{tabular}{l|l} 
4. 05 \\
3. 95 \\
3.95 \\
3.9 \\
3.9
\end{tabular} & $\begin{array}{l}4.5 \\
4.2 \\
4.1 \\
3.9 \\
3.85\end{array}$ & $\begin{array}{l}3.4 \\
3.45 \\
3.4 \\
3.45 \\
3.45\end{array}$ & $\begin{array}{l}3,3 \\
3.45 \\
3.6 \\
3.55 \\
3.5\end{array}$ \\
\hline $\begin{array}{l}11 . . \\
12 . \\
13 . \\
14 . \\
15 . .\end{array}$ & $\begin{array}{l}4.2 \\
4.1 \\
4.3 \\
4.35 \\
4.25\end{array}$ & $\begin{array}{l}3.9 \\
3.85 \\
4.15 \\
4.8 \\
4.65\end{array}$ & $\begin{array}{l}4.65 \\
4.5 \\
4.45 \\
4.4 \\
4.5\end{array}$ & $\begin{array}{l}4.15 \\
4.1 \\
4.05 \\
3.95 \\
3.9\end{array}$ & $\begin{array}{l}3.35 \\
3.3 \\
3.25 \\
3.3 \\
3.3\end{array}$ & $\begin{array}{l}5.4 \\
5.3 \\
5.5 \\
5.85 \\
5.95\end{array}$ & $\begin{array}{l}5.45 \\
5.5 \\
5.5 \\
5.9 \\
6.45\end{array}$ & $\begin{array}{l}5.0 \\
4.8 \\
4.65 \\
4.3 \\
4.15\end{array}$ & \begin{tabular}{l|l}
3.95 \\
3.9 \\
3.85 \\
3.7 \\
3.65
\end{tabular} & $\begin{array}{l}3.75 \\
3.7 \\
3.7 \\
3.65 \\
3.6\end{array}$ & $\begin{array}{l}3.4 \\
3.4 \\
3.4 \\
3.35 \\
3.35\end{array}$ & $\begin{array}{l}3.4 \\
3.25 \\
3.35 \\
3.4 \\
3.45\end{array}$ \\
\hline $\begin{array}{l}16 . . \\
17 . \\
18 . \\
19 . \\
20 .\end{array}$ & $\begin{array}{l}4.1 \\
3.85 \\
3.6 \\
6.1 \\
6.15\end{array}$ & $\begin{array}{l}5.2 \\
5.35 \\
5.6 \\
5.75 \\
5.8\end{array}$ & $\begin{array}{l}4.55 \\
4.65 \\
4.65 \\
4.7 \\
4.7\end{array}$ & $\begin{array}{l}3.85 \\
3.8 \\
3.75 \\
3.65 \\
3.65\end{array}$ & $\begin{array}{l}\text { 3. } 25 \\
\text { 3.2 } \\
\text { 3. } 2 \\
\text { 3. } 15 \\
\text { 3. } 15\end{array}$ & $\begin{array}{l}5.75 \\
5.3 \\
5.25 \\
5.35 \\
5.35\end{array}$ & $\begin{array}{l}6.6 \\
7.2 \\
7.25 \\
7.8 \\
8.4\end{array}$ & $\begin{array}{l}7.2 \\
8.15 \\
6.25 \\
5.0 \\
4.55\end{array}$ & $\begin{array}{l}3.65 \\
3.6 \\
3.65 \\
3.75 \\
3.9\end{array}$ & $\begin{array}{l}3.6 \\
3.55 \\
3.55 \\
3.5 \\
3.5\end{array}$ & $\begin{array}{l}\text { 3. } 4 \\
\text { 3. } 35 \\
\text { 3. } 3 \\
\text { 3. } 3 \\
3.3\end{array}$ & $\begin{array}{l}3.4 \\
\text { 3. } 45 \\
3.35 \\
3.2 \\
3.15\end{array}$ \\
\hline $\begin{array}{l}21 . . \\
22 . . \\
23 . . \\
24 . \\
25 . .\end{array}$ & $\begin{array}{l}6.05 \\
5.1 \\
4.95 \\
5.1 \\
4.95\end{array}$ & $\begin{array}{l}5.85 \\
6.3 \\
6.6 \\
6.3 \\
5.4\end{array}$ & $\begin{array}{l}4.7 \\
4.65 \\
4.6 \\
4.65 \\
4.65\end{array}$ & $\begin{array}{l}3.65 \\
3.6 \\
3.6 \\
3.55 \\
3.55\end{array}$ & $\begin{array}{l}3.1 \\
3.1 \\
\text { 3. } 55 \\
3.3 \\
3.8\end{array}$ & $\begin{array}{l}5.05 \\
4.85 \\
4.75 \\
4.55 \\
4.45\end{array}$ & $\begin{array}{l}7.6 \\
7.0 \\
6.6 \\
6.2 \\
5.85\end{array}$ & $\begin{array}{l}4.25 \\
4.15 \\
4.4 \\
4.5 \\
4.5\end{array}$ & $\begin{array}{l}3.9 \\
4.0 \\
4.25 \\
4.1 \\
3.9\end{array}$ & $\begin{array}{l}3.5 \\
3.5 \\
3.45 \\
3.45 \\
3.4\end{array}$ & $\begin{array}{l}\text { 3. } 4 \\
\text { 3. } \\
\text { 3. } 55 \\
\text { 3. } 5 \\
3.5\end{array}$ & $\begin{array}{l}\text { 3. } 1 \\
\text { 3. } \\
\text { 3. } 25 \\
\text { 3. } 35 \\
\text { 3. } 3\end{array}$ \\
\hline $30 \ldots$ & $\begin{array}{l}4.85 \\
5.0 \\
4.75 \\
4.55 \\
4.5 \\
4.5\end{array}$ & $\begin{array}{l}4.95 \\
4.75 \\
4.6\end{array}$ & $\begin{array}{l}4.65 \\
4.6 \\
4.6 \\
4.65 \\
4.7 \\
4.9\end{array}$ & $\begin{array}{l}3.5 \\
3.5 \\
3.5 \\
3.45 \\
3.55\end{array}$ & $\begin{array}{l}3.8 \\
3.7 \\
3.65 \\
3.65 \\
3.6 \\
3.5\end{array}$ & $\begin{array}{l}5.0 \\
5.15 \\
4.95 \\
4.55 \\
4.15\end{array}$ & $\begin{array}{l}5.6 \\
5.55 \\
5.6 \\
5.9 \\
5.75 \\
5.2\end{array}$ & $\begin{array}{l}4.35 \\
4.3 \\
4.4 \\
4.75 \\
5.35 \\
5.25\end{array}$ & $\begin{array}{l}3.85 \\
3.8 \\
3.95 \\
4.35 \\
4.15\end{array}$ & $\begin{array}{l}3.4 \\
3.35 \\
3.35 \\
3.4 \\
3.45 \\
3.4\end{array}$ & $\begin{array}{l}\text { 3. } 45 \\
\text { 3. } 45 \\
\text { 3. } 45 \\
\text { 3. } 4 \\
3.4\end{array}$ & $\begin{array}{l}3.35 \\
3.35 \\
3.35 \\
3.3 \\
3.3 \\
3.15\end{array}$ \\
\hline $\begin{array}{r}190 \\
1 \ldots \ldots \\
2 \ldots \ldots \\
3 \ldots \ldots \\
4 \ldots \ldots \\
5 \ldots \ldots \\
\end{array}$ & $\begin{array}{l}\text { 3. } 05 \\
3.0 \\
3.05 \\
3.15 \\
3.25\end{array}$ & $\begin{array}{l}\text { 3. } 25 \\
\text { 3. } 2 \\
3.2 \\
\text { 3. } 15 \\
\text { 3. } 25\end{array}$ & $\begin{array}{l}4.85 \\
4.7 \\
4.55 \\
4.45 \\
4.3\end{array}$ & $\begin{array}{l}4.1 \\
3.95 \\
3.8 \\
3.75 \\
3.75\end{array}$ & $\begin{array}{l}3.9 \\
3.95 \\
3.9 \\
3.85 \\
3.8\end{array}$ & $\begin{array}{l}7.15 \\
6.55 \\
6.15 \\
5.85 \\
5.45\end{array}$ & $\begin{array}{l}6.05 \\
5.85 \\
5.45 \\
5.3 \\
5.15\end{array}$ & $\begin{array}{l}3.8 \\
3.8 \\
3.75 \\
3.7 \\
3.7\end{array}$ & $\begin{array}{l}3.4 \\
3.35 \\
3.35 \\
3.35 \\
3.3\end{array}$ & $\begin{array}{l}2.95 \\
2.95 \\
2.9 \\
2.9 \\
2.95\end{array}$ & $\begin{array}{l}\text { 3. } 4 \\
\text { 3. } 35 \\
\text { 3. } 3 \\
\text { 3. } 25 \\
\text { 3. } 25\end{array}$ & $\begin{array}{l}\text { 3. } 15 \\
\text { 3.05 } \\
3.05 \\
3.1 \\
3.05\end{array}$ \\
\hline $\begin{array}{r}6 \ldots \\
7 \ldots \\
8 \ldots \\
9 \ldots \\
10 \ldots\end{array}$ & $\begin{array}{l}\text { 3. } 25 \\
3.2 \\
3.15 \\
3.1 \\
3.05\end{array}$ & $\begin{array}{l}3.2 \\
3.15 \\
3.15 \\
3.15 \\
3.2\end{array}$ & $\begin{array}{l}4.25 \\
4.7 \\
4.95 \\
5.2 \\
6.15\end{array}$ & $\begin{array}{l}3.75 \\
3.75 \\
3.7 \\
3.75 \\
3.7\end{array}$ & $\begin{array}{l}3.75 \\
3.65 \\
3.6 \\
3.7 \\
3.75\end{array}$ & $\begin{array}{l}5.25 \\
5.1 \\
4.95 \\
4.8 \\
4.65\end{array}$ & $\begin{array}{l}5.05 \\
4.8 \\
4.65 \\
4.85 \\
5.15\end{array}$ & $\begin{array}{l}3.6 \\
3.55 \\
3.55 \\
3.5 \\
3.5\end{array}$ & $\begin{array}{l}3.3 \\
3.2 \\
3.2 \\
3.2 \\
3.15\end{array}$ & $\begin{array}{l}2.95 \\
2.9 \\
2.9 \\
2.9 \\
2.95\end{array}$ & $\begin{array}{l}3.2 \\
3.2 \\
3.2 \\
3.15 \\
3.1\end{array}$ & $\begin{array}{l}3.1 \\
3.1 \\
3.05 \\
3.05 \\
3.0\end{array}$ \\
\hline $\begin{array}{l}15 \ldots \\
14 \ldots \\
15 \ldots . . .\end{array}$ & $\begin{array}{l}3.05 \\
3.1 \\
3.05 \\
3.05 \\
3.1\end{array}$ & $\begin{array}{l}3.25 \\
4.8 \\
5.2 \\
4.7 \\
4.45\end{array}$ & $\begin{array}{l}6.2 \\
6.05 \\
5.7 \\
5.4 \\
5.25\end{array}$ & $\begin{array}{l}\text { 3. } 75 \\
3.7 \\
3.75 \\
3.75 \\
3.7\end{array}$ & $\begin{array}{l}4.1 \\
4.05 \\
4.1 \\
4.2 \\
4.0\end{array}$ & $\begin{array}{l}4.6 \\
4.6 \\
4.65 \\
4.6 \\
4.5\end{array}$ & $\begin{array}{l}5.25 \\
5.2 \\
4.95 \\
4.6 \\
4.4\end{array}$ & $\begin{array}{l}3.5 \\
3.5 \\
3.55 \\
3.5 \\
3.5\end{array}$ & $\begin{array}{l}3.15 \\
3.1 \\
3.05 \\
3.05 \\
3.0\end{array}$ & $\begin{array}{l}2.95 \\
3.0 \\
3.0 \\
2.95 \\
2.95\end{array}$ & $\begin{array}{l}3.1 \\
3.1 \\
3.05 \\
3.1 \\
3.15\end{array}$ & $\begin{array}{l}3.0 \\
3.0 \\
3.05 \\
3.1 \\
3.05\end{array}$ \\
\hline 16. & $\begin{array}{l}3.15 \\
3.2 \\
3.15 \\
3.1 \\
3.15\end{array}$ & $\begin{array}{l}4.9 \\
4.7 \\
4.65 \\
4.5 \\
4.6\end{array}$ & $\begin{array}{l}5.25 \\
5.15 \\
4.85 \\
4.65 \\
4.4\end{array}$ & $\begin{array}{l}3.65 \\
3.65 \\
3.6 \\
3.6 \\
3.6\end{array}$ & $\begin{array}{l}3.9 \\
4.1 \\
4.45 \\
4.55 \\
4.6\end{array}$ & $\begin{array}{l}4.35 \\
4.3 \\
4.25 \\
4.2 \\
4.5\end{array}$ & $\begin{array}{l}4.35 \\
4.4 \\
4.3 \\
4.3 \\
4.85\end{array}$ & $\begin{array}{l}3.5 \\
3.45 \\
3.45 \\
3.65 \\
3.6\end{array}$ & $\begin{array}{l}3.0 \\
3.0 \\
2.95 \\
2.95 \\
2.95\end{array}$ & $\begin{array}{l}2.95 \\
3.0 \\
3.0 \\
3.0 \\
2.95\end{array}$ & $\begin{array}{l}3.1 \\
3.1 \\
3.05 \\
3.0 \\
2.95\end{array}$ & $\begin{array}{l}3.1 \\
3.15 \\
3.15 \\
3.25 \\
3.15\end{array}$ \\
\hline $\begin{array}{l}23 \ldots \ldots \ldots \\
24 \ldots \ldots \ldots \ldots \\
25 \ldots \ldots \ldots \ldots\end{array}$ & $\begin{array}{l}\text { 3. } 2 \\
3.2 \\
3.15 \\
3.05 \\
\text { 3. } 05\end{array}$ & $\begin{array}{l}4.55 \\
4.35 \\
4.3 \\
4.25 \\
5.2\end{array}$ & $\begin{array}{l}4.25 \\
4.1 \\
4.0 \\
3.85 \\
3.95\end{array}$ & $\begin{array}{l}3.55 \\
3.7 \\
3.85 \\
3.85 \\
3.9\end{array}$ & $\begin{array}{l}4.5 \\
4.35 \\
4.4 \\
4.8 \\
5.7\end{array}$ & $\begin{array}{l}4.6 \\
5.2 \\
5.25 \\
5.65 \\
6.65\end{array}$ & $\begin{array}{l}5.45 \\
5.9 \\
5.55 \\
4.9 \\
4.5\end{array}$ & $\begin{array}{l}3.6 \\
3.55 \\
3.5 \\
3.45 \\
3.45\end{array}$ & $\begin{array}{l}2.95 \\
2.9 \\
2.9 \\
2.9 \\
2.9\end{array}$ & $\begin{array}{l}2.95 \\
2.95 \\
2.95 \\
3.0 \\
3.1\end{array}$ & $\begin{array}{l}2.95 \\
2.95 \\
2.9 \\
2.95 \\
3.15\end{array}$ & $\begin{array}{l}3.1 \\
3.1 \\
3.05 \\
3.0 \\
3.0\end{array}$ \\
\hline $\begin{array}{l}29 \ldots \ldots \\
30 \ldots \ldots \\
31 \ldots \ldots\end{array}$ & $\begin{array}{l}3.15 \\
3.2 \\
3.15 \\
3.2 \\
3.2 \\
3.25\end{array}$ & $\begin{array}{l}5.05 \\
5.0 \\
4.95 \\
4.8\end{array}$ & $\begin{array}{l}3.85 \\
3.85 \\
3.8 \\
3.75 \\
3.75 \\
4.05\end{array}$ & $\begin{array}{l}3.8 \\
3.75 \\
3.75 \\
3.85 \\
3.85\end{array}$ & $\begin{array}{l}6.55 \\
6.85 \\
7.2 \\
7.7 \\
8.65 \\
8.05\end{array}$ & $\begin{array}{l}8.0 \\
7.65 \\
7.45 \\
7.35 \\
6.35\end{array}$ & $\begin{array}{l}4.3 \\
4.2 \\
4.1 \\
4.0 \\
3.95 \\
3.9\end{array}$ & $\begin{array}{l}3.4 \\
3.35 \\
3.35 \\
3.4 \\
3.4 \\
3.4\end{array}$ & $\begin{array}{l}2.85 \\
2.9 \\
3.05 \\
3.0 \\
3.0\end{array}$ & $\begin{array}{l}3.2 \\
3.3 \\
3.4 \\
3.45 \\
3.5 \\
3.45\end{array}$ & $\begin{array}{l}3.1 \\
3.1 \\
3.05 \\
3.05 \\
3.25\end{array}$ & $\begin{array}{l}3.0 \\
3.0 \\
2.95 \\
2.95 \\
2.9 \\
2.9\end{array}$ \\
\hline
\end{tabular}

$a$ Ice conditions from January 7 to February 20, 1907

$b$ Ice conditions from January 14 to March 9, and December 2 to $31,1908$. 
Rating table for Cedar River at Cedar Rapids, Iowa, for 1906 to 1908.

\begin{tabular}{|c|c|c|c||c|r|r|r|}
\hline $\begin{array}{c}\text { Gage } \\
\text { height. }\end{array}$ & $\begin{array}{c}\text { Dis- } \\
\text { charge. }\end{array}$ & $\begin{array}{c}\text { Gage } \\
\text { height. }\end{array}$ & $\begin{array}{c}\text { Dis- } \\
\text { charge. }\end{array}$ & $\begin{array}{c}\text { Gage } \\
\text { height. }\end{array}$ & $\begin{array}{c}\text { Dis- } \\
\text { charge. }\end{array}$ & $\begin{array}{c}\text { Gage } \\
\text { height. }\end{array}$ & $\begin{array}{c}\text { Dis- } \\
\text { charge. }\end{array}$ \\
\hline & - & - & & & & \\
Fect. & Sec.-ft. & Feet. & Sec.-ft. & Fect. & Sec.-ft. & Feet. & Sec.-ft. \\
2.90 & 840 & 4.10 & 3.475 & 5.30 & 7,550 & 7.00 & 13,850 \\
3.00 & 970 & 4.20 & 3,800 & 5.40 & 7,900 & 7.20 & 14,640 \\
3.10 & 1,110 & 4.30 & 4,125 & 5.50 & 8,250 & 7.40 & 15,430 \\
3.20 & 1,270 & 4.40 & 4,450 & 5.60 & 8,600 & 7.60 & 16,220 \\
3.30 & 1,440 & 4.50 & 4,775 & 5.70 & 8,950 & 7.80 & 17,010 \\
3.40 & 1,625 & 4.60 & 5,100 & 5.80 & 9,300 & 8.00 & 17,800 \\
3.50 & 1,825 & 4.70 & 5,450 & 5.90 & 9,650 & 8.20 & 18,590 \\
3.60 & 2,050 & 4.80 & 5,800 & 6.00 & 10,000 & 8.40 & 19,380 \\
3.70 & 2,300 & 4.90 & 6,150 & 6.20 & 10.750 & 8.60 & 20,170 \\
3.80 & 2,575 & 5.00 & 6,500 & 6.40 & 11,510 & 8.80 & 20,960 \\
3.90 & 2,875 & 5.10 & 6.850 & 6.60 & 12,280 & & \\
4.00 & 3,175 & 5.20 & 7,200 & 6.80 & 13,060 & & \\
\hline
\end{tabular}

NotE.-The above table is not applicable for ice or obstructed-channel conditions. It is based on 34 discharge measurements made during 1903 to 1966 and is well defined. Above gage height 7 feet the rating curve is a tangent, the difference being 395 per tenth.

Monthly discharge of Cedar River at Cedar Rapids, Iowa, for 1907 and 1908.

[Drainage area, 6,320 square miles.]

\begin{tabular}{|c|c|c|c|c|c|c|}
\hline \multirow[b]{2}{*}{ Month. } & \multicolumn{4}{|c|}{ Discharge in second-feet. } & \multirow{2}{*}{$\begin{array}{l}\text { Run-off } \\
\text { (depth in } \\
\text { inches on } \\
\text { drainage } \\
\text { area). }\end{array}$} & \multirow{2}{*}{$\begin{array}{l}\text { Accu- } \\
\text { racy. }\end{array}$} \\
\hline & Maximum. & Minimum. & Mean. & $\begin{array}{c}\text { Per } \\
\text { square } \\
\text { mile. }\end{array}$ & & \\
\hline 1907. & & & & & & \\
\hline $\begin{array}{l}\text { January.... } \\
\text { February.. }\end{array}$ & $\begin{array}{l}10,600 \\
12,300\end{array}$ & $\begin{array}{l}2,050 \\
2,720\end{array}$ & $\begin{array}{l}., 410 \\
6,130\end{array}$ & $\begin{array}{r}0.856 \\
.970\end{array}$ & 0.99 & A. \\
\hline March. . & 12,100 & 4,450 & 6,040 & .956 & 1. 10 & A. \\
\hline April.. & 6,680 & 1,720 & 3,280 & .519 & .58 & A. \\
\hline May... & 2,580 & 1,110 & 1,740 & .275 & .32 & A. \\
\hline June. & 9,820 & 1,720 & 5,650 & .894 & 1.00 & A. \\
\hline July......... & 19,400 & 3,320 & 9,350 & 1.48 & 1.71 & A. \\
\hline August....... & 18,400 & 3,640 & 6,090 & .964 & 1. 11 & A. \\
\hline September. & 6,320 & 2,050 & 3,250 & .514 & .57 & A. \\
\hline October.... & 7,020 & 1,530 & 2,710 & .429 & .49 & A. \\
\hline November.. & 1,940 & 1,440 & 1,650 & .261 & .29 & A. \\
\hline December.. & 2,050 & 1,110 & 1,510 & .239 & .28 & A. \\
\hline The year. & 19,400 & 1,110 & 4,400 & .699 & 9.45 & \\
\hline Januarv ....... & 1,360 & 970 & 1,170 & .185 & & B. \\
\hline February. & 7,200 & $\begin{array}{r}970 \\
1,190\end{array}$ & $\begin{array}{l}1,160 \\
3,920\end{array}$ & $\begin{array}{l}.180 \\
.620\end{array}$ & .67 & $\begin{array}{l}\text { B. } \\
\text { A. }\end{array}$ \\
\hline March... & 10,800 & 2,440 & 5,370 & .850 & .98 & A. \\
\hline April. & 3,480 & 1,940 & 2,460 & .389 & .43 & $\Lambda$. \\
\hline May. . & 20,400 & 2,050 & 6,030 & .954 & 1. 10 & A. \\
\hline June.. & 17,800 & 3,800 & 8,330 & 1.32 & 1. 47 & A. \\
\hline July.. & 10,200 & 2,880 & 5,940 & .940 & 1.08 & A. \\
\hline August. & 2,580 & 1,530 & 1,910 & .302 & .35 & A. \\
\hline September & 1,620 & 840 & 1,100 & .174 & .19 & B. \\
\hline Oetober..... & 1,820 & 840 & 1,050 & .166 & .19 & B. \\
\hline November.. & 1,620 & 840 & 1,150 & .182 & .20 & B. \\
\hline December... & 1,360 & 840 & 1,050 & .166 & .19 & $\mathrm{~B}$. \\
\hline The year. & 20,400 & 840 & 3,290 & .521 & 7.06 & \\
\hline
\end{tabular}

Note.-Open-channel rating applied during the periods of ice conditions; accuracy only very slightly affected thereby.

The above values of accuracy are dependent on the constancy of conditions of flow since the last measurements were made in 1906.

\section{SANGAMON RIVER DRAINAGE BASIN.}

\section{DESCRIPTION.}

The drainage basin of Sangamon River lies wholly within the State of Illinois, very nearly in the center of the State. The river rises in the southwestern part of Ford County, flows southwestward to Decatur, in Macon County, thence westward to a point near 
Springfield, northwestward to its junction with Salt Creek at the northern boundary line of Menard County, and westward to its junction with Illinois River at the northern boundary of Cass County. Springfield is about 20 miles southwest of the center of the basin, which is roughly a right triangle in shape, with the mouth of the river opposite the vertical. The total drainage area is about 5,180 square miles. The principal tributaries are Salt Creek and South Fork.

The eastern third of the drainage basin is somewhat undulating and elevated, the rest of the basin is a level prairie. The soil is very fertile, rich, black loam, especially adapted for raising corn. There are coal mines in the vicinity of Springfield. The bed and banks of the river are soft and insecure. The slope of the river is small. The elevation of its source is about 700 feet above sea level, and that of its mouth is about 430 feet. The only timber in this drainage basin is in small groves or along the river banks.

The annual rainfall is about 37 inches. The winters are mild. Ice forms to some extent, and during severe winters attains considerable thickness.

Storage possibilities have not been investigated, but are of considerable interest.

The basin contains numerous swamp areas, and is so level and low that very little ground storage is available. High water follows every heavy rain, floods are of frequent occurrence and considerable duration, and as the banks of the river are low large areas are flooded. The drainage of the swamps and the opening up of channels so that flood waters may have an opportunity of returning quickly to the main stream makes the study of flood control and drainage of considerable importance. In some places short sections of the main stream are being straightened in an effort to provide a better channel so that floods will quickly drain off the adjacent land. Such work is of doubtful value, for in a few years at the most the river will return to its former channel or make new channels in order to keep in equilibrium. Any improvement of this nature should take into account the stream as a whole and should be commenced at the lower end.

On account of the low slope, floods, low water, and lack of suitable foundations for dams, opportunities for water power are lacking.

The following gaging stations are being maintained in this drainage basin:

Sangamon River at Monticello, Ill., 1908.

Sangamon River at Decatur, Ill., 1905.

Sangamon River at Riverton, Ill., 1908.

Sangamon River at Springfield, Ill., 1903.

Sangamon River near Chandlerville, Ill., 1908.

South Fork of Sangamon River near Taylorville, Ill., 1908.

Salt Creek near Kenney, Ill., 1908. 


\section{SANGAMON RIVER AT MONTICELLO, ILL.}

This station, which is located at the Illinois Central bridge, about one-half mile west of the town of Monticello, Ill., was established February 4, 1908, for the purpose of collecting data to be used in studying drainage, water supply, and flood control.

No important tributaries enter near this station. The drainage area above the section is about 544 square miles.

The datum of the gage has not been changed. The records are reliable and accurate; the figures for low-water discharge should be used with caution until verified by more measurements.

The daily and monthly discharge have not yet been determined on account of insufficient data.

Discharge measurements of Sangamon River at Monticello, Ill., in 1908.

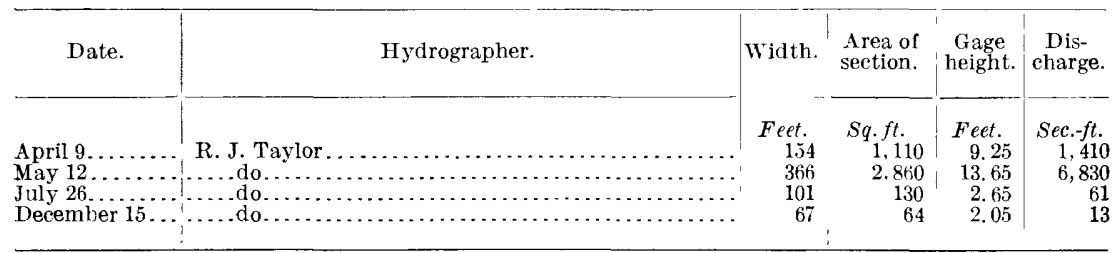

Daily gage height, in feet, of Sangamon River at Monticello, Ill., for 1908.

[Martin Doyle, observer.]

\begin{tabular}{|c|c|c|c|c|c|c|c|c|c|c|c|}
\hline Day. & Feb. & Mar. & Apr. & May. & June. & July. & Aug. & Sept. & Oct. & Nov. & Dec. \\
\hline $\begin{array}{l}1 . . \\
2 . . \\
3 . . \\
4 . . \\
5 . .\end{array}$ & $\begin{array}{l}4.2 \\
6.1\end{array}$ & $\begin{array}{r}9.9 \\
10.0 \\
10.5 \\
10.7 \\
10.7\end{array}$ & $\begin{array}{l}6.6 \\
6.7 \\
6.5 \\
6.3 \\
6.2\end{array}$ & $\begin{array}{r}10.0 \\
9.1 \\
8.5 \\
9.6 \\
11.3\end{array}$ & $\begin{array}{l}7.3 \\
6.8 \\
6.4 \\
6.2 \\
6.0\end{array}$ & $\begin{array}{l}3.1 \\
3.7 \\
3.3 \\
3.2 \\
3.1\end{array}$ & $\begin{array}{l}2.2 \\
2.2 \\
2.2 \\
2.1 \\
2.1\end{array}$ & $\begin{array}{l}2.0 \\
1.9 \\
1.9 \\
1.9 \\
1.9\end{array}$ & $\begin{array}{l}1.9 \\
1.9 \\
1.9 \\
1.9 \\
1.8\end{array}$ & $\begin{array}{l}2.0 \\
2.0 \\
2.0 \\
2.0 \\
2.0\end{array}$ & $\begin{array}{l}2.2 \\
2.2 \\
2.2 \\
2.2 \\
2.2\end{array}$ \\
\hline $\begin{array}{l}6 \ldots \ldots \\
7 \ldots \ldots \\
8 \ldots \ldots \\
99 \ldots \\
10 \ldots \ldots \\
9 . \ldots .\end{array}$ & $\begin{array}{l}8.6 \\
9.0 \\
8.3 \\
7.7 \\
6.9\end{array}$ & $\begin{array}{l}10.7 \\
10.7 \\
10.8 \\
10.7 \\
10.2\end{array}$ & $\begin{array}{l}6.2 \\
6.1 \\
6.8 \\
9.1 \\
9.4\end{array}$ & $\begin{array}{l}11.5 \\
12.5 \\
13.5 \\
13.1 \\
12.8\end{array}$ & $\begin{array}{l}5.6 \\
5.4 \\
5.1 \\
5.0 \\
4.9\end{array}$ & $\begin{array}{l}3.0 \\
3.0 \\
2.9 \\
2.9 \\
2.9\end{array}$ & $\begin{array}{l}2.1 \\
2.1 \\
2.1 \\
2.0 \\
2.0\end{array}$ & $\begin{array}{l}1.8 \\
1.8 \\
1.8 \\
1.8 \\
1.8\end{array}$ & $\begin{array}{l}1.8 \\
1.8 \\
1.8 \\
1.8 \\
1.8\end{array}$ & $\begin{array}{l}2.0 \\
2.0 \\
2.0 \\
2.0 \\
2.0\end{array}$ & $\begin{array}{l}2.1 \\
2.1 \\
2.1 \\
2.0\end{array}$ \\
\hline $\begin{array}{l}14 \ldots \ldots \ldots \\
15, \ldots \ldots \ldots\end{array}$ & $\begin{array}{r}6.3 \\
7.3 \\
8.6 \\
10.2 \\
11.2\end{array}$ & $\begin{array}{l}9.6 \\
9.2 \\
8.8 \\
8.4 \\
8.0\end{array}$ & $\begin{array}{l}8.8 \\
8.2 \\
7.4 \\
7.2 \\
6.9\end{array}$ & $\begin{array}{l}11.8 \\
13.6 \\
14.6 \\
15.2 \\
14.0\end{array}$ & $\begin{array}{l}4.7 \\
4.5 \\
4.3 \\
4.4 \\
4.4\end{array}$ & $\begin{array}{l}2.8 \\
2.8 \\
2.7 \\
2.9 \\
3.1\end{array}$ & $\begin{array}{l}2.0 \\
2.0 \\
2.1 \\
2.3 \\
2.2\end{array}$ & $\begin{array}{l}1.8 \\
1.8 \\
1.8 \\
1.8 \\
1.8\end{array}$ & $\begin{array}{l}1.8 \\
1.8 \\
1.8 \\
1.8 \\
1.8\end{array}$ & $\begin{array}{l}2.0 \\
2.0 \\
2.0 \\
2.0 \\
2.0\end{array}$ & \begin{tabular}{r}
2.0 \\
2.0 \\
\hdashline .0 \\
2.0
\end{tabular} \\
\hline $\begin{array}{l}16 \ldots \ldots \\
17 \ldots \ldots \\
18 \ldots \ldots \\
19 \ldots \ldots \\
20 \ldots \ldots\end{array}$ & $\begin{array}{r}11.4 \\
12.0 \\
11.3 \\
10.2 \\
8.2\end{array}$ & $\begin{array}{l}7.4 \\
7.1 \\
7.1 \\
8.0 \\
8.7\end{array}$ & $\begin{array}{l}6.9 \\
7.0 \\
7.0 \\
6.8 \\
6.7\end{array}$ & $\begin{array}{l}12.6 \\
11.7 \\
12.0 \\
11.6 \\
11.5\end{array}$ & $\begin{array}{l}4.2 \\
4.0 \\
3.9 \\
3.8 \\
3.8\end{array}$ & $\begin{array}{l}2.9 \\
2.8 \\
2.7 \\
2.6 \\
2.6\end{array}$ & $\begin{array}{l}2.2 \\
2.2 \\
2.1 \\
2.0 \\
2.0\end{array}$ & $\begin{array}{l}1.8 \\
1.8 \\
1.8 \\
1.8 \\
1.8\end{array}$ & $\begin{array}{l}1.8 \\
1.8 \\
1.8 \\
1.8 \\
1.8\end{array}$ & $\begin{array}{l}2.0 \\
2.0 \\
2.0 \\
2.0 \\
2.0\end{array}$ & $\begin{array}{l}2.0 \\
2.0 \\
2.0 \\
2.0\end{array}$ \\
\hline $\begin{array}{l}21 \ldots \\
22 \ldots \\
23 \ldots \\
24 \ldots \\
25 . \ldots\end{array}$ & $\begin{array}{l}8.0 \\
7.7 \\
7.9 \\
7.4 \\
8.3\end{array}$ & $\begin{array}{l}8.9 \\
8.5 \\
7.9 \\
7.3 \\
6.9\end{array}$ & $\begin{array}{r}6.4 \\
6.0 \\
6.0 \\
8.0 \\
\mathbf{1 0 . 1}\end{array}$ & $\begin{array}{r}11.5 \\
11.6 \\
10.8 \\
10.1 \\
9.7\end{array}$ & $\begin{array}{l}3.7 \\
\text { 3. } \\
\text { 3. } 5 \\
3.4 \\
3.3\end{array}$ & $\begin{array}{l}2.6 \\
2.6 \\
2.5 \\
2.5 \\
2.6\end{array}$ & $\begin{array}{l}2.0 \\
2.0 \\
1.9 \\
1.9 \\
1.9\end{array}$ & $\begin{array}{l}1.8 \\
1.8 \\
1.8 \\
1.8 \\
1.8\end{array}$ & $\begin{array}{l}1.8 \\
1.9 \\
1.9 \\
1.9 \\
1.9\end{array}$ & $\begin{array}{l}2.0 \\
2.0 \\
2.1 \\
2.1 \\
2.1\end{array}$ & $\begin{array}{l}2.0 \\
2.0 \\
2.0 \\
2.0 \\
2.0\end{array}$ \\
\hline $\begin{array}{l}26 \ldots \\
27 \ldots \\
28 \ldots \\
29 \ldots \\
30 \ldots \\
31 \ldots\end{array}$ & $\begin{array}{l}10.1 \\
10.6 \\
10.5 \\
10.5\end{array}$ & $\begin{array}{l}6.6 \\
6.3 \\
6.3 \\
6.9 \\
6.4 \\
6.6\end{array}$ & $\begin{array}{l}10.5 \\
11.1 \\
11.0 \\
10.8 \\
10.7\end{array}$ & $\begin{array}{l}9.2 \\
8.7 \\
8.2 \\
8.1 \\
8.0 \\
7.8\end{array}$ & $\begin{array}{l}3.2 \\
3.1 \\
3.1 \\
3.2 \\
3.2\end{array}$ & $\begin{array}{l}2.6 \\
2.5 \\
2.5 \\
2.4 \\
2.3 \\
2.3\end{array}$ & $\begin{array}{l}1.9 \\
1.9 \\
1.9 \\
1.9 \\
1.9 \\
1.9\end{array}$ & $\begin{array}{l}1.8 \\
1.8 \\
1.9 \\
1.9 \\
1.9\end{array}$ & $\begin{array}{l}1.9 \\
1.9 \\
2.0 \\
2.0 \\
2.0 \\
2.0\end{array}$ & $\begin{array}{c}2.2 \\
2.2 \\
2.1 \\
2.3\end{array}$ & $\begin{array}{c}2.0 \\
2.0 \\
2.0 \\
2.3 \\
2.4\end{array}$ \\
\hline
\end{tabular}




\section{SANGAMON RIVER AT RIVERTON, ILL.}

This station is located at the Wabash Railroad bridge about onefourth mile west of the depot at Riverton, Ill. It was established February 13, 1908, to obtain data to be used in the study of drainage and flood-control problems.

The South Fork enters 2 or 3 miles above the station. The drainage area above the section is about 2,530 square miles.

The datum of the gage has not been changed. The records are reliable and accurate.

Sufficient data have not been collected to enable determination of the daily and monthly discharge.

Discharge measurements of Sangamon River at Riverton, Ill., in 1908.

\begin{tabular}{|c|c|c|c|c|c|}
\hline Date. & Hydrographer. & Width. & $\begin{array}{l}\text { Area of } \\
\text { section. }\end{array}$ & $\begin{array}{c}\text { Gage } \\
\text { height. }\end{array}$ & $\begin{array}{c}\text { Dis- } \\
\text { charge. }\end{array}$ \\
\hline $\begin{array}{l}\text { February } 13 \ldots \\
\text { July } 27 \ldots \ldots\end{array}$ & $\begin{array}{c}\text { R. J. Taylor. } \\
\text {....do ........ }\end{array}$ & $\begin{array}{r}\text { Feet. } \\
218 \\
151\end{array}$ & $\begin{array}{r}S q . \\
2,200 \\
733\end{array}$ & $\begin{array}{c}\text { Fect. } \\
16.50 \\
8.4\end{array}$ & $\begin{array}{r}\text { Sec. }-f t . \\
3,760 \\
326\end{array}$ \\
\hline
\end{tabular}

Daily gage height, in feet, of Sangamon River at Riverton, Ill., for 1908.

[B. H. Watson, observer.]

\begin{tabular}{|c|c|c|c|c|c|c|c|c|c|c|c|}
\hline Day. & Feb. & Mar. & Apr. & May. & June. & July. & Aug. & Sept. & Oct. & Nov. & Dec. \\
\hline $\begin{array}{l}1 \ldots \ldots \ldots \\
2 \ldots \ldots \ldots \\
3 \ldots \ldots \\
4 \ldots \ldots \\
5 \ldots \ldots\end{array}$ & $\begin{array}{c}\cdots \\
\cdots \\
\cdots \\
\cdots\end{array}$ & $\begin{array}{l}22.1 \\
21.9 \\
21.7 \\
21.5 \\
21.3\end{array}$ & $\begin{array}{l}15.9 \\
16.0 \\
16.1 \\
16.0 \\
15.8\end{array}$ & $\begin{array}{l}20.4 \\
19.8 \\
19.4 \\
21.8 \\
23.1\end{array}$ & $\begin{array}{l}16.2 \\
1 \tilde{y} .1 \\
14.3 \\
13.8 \\
13.5\end{array}$ & $\begin{array}{l}9.5 \\
9.4 \\
9.2 \\
9.0 \\
9.0\end{array}$ & $\begin{array}{l}8.0 \\
7.9 \\
7.9 \\
7.8 \\
7.8\end{array}$ & $\begin{array}{l}7.6 \\
7.6 \\
7.5 \\
7.5 \\
7.4\end{array}$ & $\begin{array}{l}7.0 \\
7.0 \\
6.9 \\
6.9 \\
6.9\end{array}$ & $\begin{array}{l}6.7 \\
6.7 \\
6.7 \\
6.6 \\
6.6\end{array}$ & $\begin{array}{l}7.1 \\
7.1 \\
7.1 \\
7.1 \\
7.1\end{array}$ \\
\hline 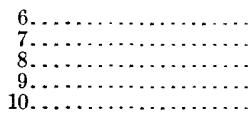 & $\ldots$ & $\begin{array}{l}21.6 \\
21.5 \\
21.6 \\
22.1 \\
22.3\end{array}$ & $\begin{array}{l}15.7 \\
16.0 \\
16.4 \\
16.7 \\
16.9\end{array}$ & $\begin{array}{l}23.8 \\
24.8 \\
26.3 \\
26.4 \\
26.0\end{array}$ & $\begin{array}{l}13.2 \\
12.9 \\
12.5 \\
12.0 \\
11.9\end{array}$ & $\begin{array}{r}8.9 \\
9.7 \\
10.6 \\
10.5 \\
10.0\end{array}$ & $\begin{array}{l}7.7 \\
7.7 \\
7.7 \\
7.7 \\
7.7\end{array}$ & $\begin{array}{l}7.3 \\
7.3 \\
7.2 \\
7.2 \\
7.2\end{array}$ & $\begin{array}{l}6.9 \\
6.9 \\
6.9 \\
6.9 \\
6.9\end{array}$ & $\begin{array}{l}6.6 \\
6.6 \\
6.6 \\
6.6 \\
6.6\end{array}$ & $\begin{array}{l}7.1 \\
7.1 \\
7.1 \\
7.1 \\
7.1\end{array}$ \\
\hline 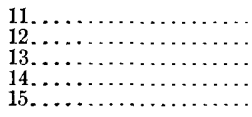 & $\begin{array}{l}\cdots \ldots \\
16.5 \\
18.0 \\
19.9\end{array}$ & $\begin{array}{l}22.1 \\
21.9 \\
21.7 \\
21.5 \\
21.0\end{array}$ & $\begin{array}{l}17.1 \\
17.1 \\
17.0 \\
16.9 \\
16.4\end{array}$ & $\begin{array}{l}25.8 \\
25.4 \\
24.8 \\
24.3 \\
23.3\end{array}$ & $\begin{array}{l}11.7 \\
11.5 \\
11.4 \\
11.0 \\
10.8\end{array}$ & $\begin{array}{l}9.5 \\
9.3 \\
9.1 \\
8.9 \\
8.7\end{array}$ & $\begin{array}{l}7.7 \\
7.7 \\
7.7 \\
7.7 \\
7.7\end{array}$ & $\begin{array}{l}7.2 \\
7.2 \\
7.2 \\
7.2 \\
7.2\end{array}$ & $\begin{array}{l}6.9 \\
6.9 \\
6.9 \\
6.8 \\
6.8\end{array}$ & $\begin{array}{l}6.6 \\
6.6 \\
6.6 \\
6.6 \\
6.6\end{array}$ & $\begin{array}{l}7.1 \\
7.1 \\
7.1 \\
7.1 \\
7.1\end{array}$ \\
\hline $\begin{array}{l}16 \ldots \ldots \ldots \\
17 . \ldots \ldots \ldots \\
18 \ldots \ldots \\
19 \ldots \ldots \\
20 \ldots \ldots\end{array}$ & $\begin{array}{l}20.0 \\
20.9 \\
20.5 \\
20.0 \\
20.4\end{array}$ & $\begin{array}{l}20.7 \\
19.5 \\
17.1 \\
16.5 \\
16.0\end{array}$ & $\begin{array}{l}15.9 \\
15.1 \\
14.5 \\
14.0 \\
13.9\end{array}$ & $\begin{array}{l}23.2 \\
23.4 \\
23.5 \\
23.1 \\
22.6\end{array}$ & $\begin{array}{r}10.6 \\
10.4 \\
10.3 \\
10.2 \\
9.9\end{array}$ & $\begin{array}{l}8.7 \\
8.6 \\
8.6 \\
8.5 \\
8.5\end{array}$ & $\begin{array}{l}7.7 \\
7.7 \\
7.6 \\
7.6 \\
7.6\end{array}$ & $\begin{array}{l}7.2 \\
7.1 \\
7.1 \\
7.0 \\
6.9\end{array}$ & $\begin{array}{l}6.8 \\
6.8 \\
6.8 \\
6.8 \\
6.8\end{array}$ & $\begin{array}{l}6.6 \\
6.7 \\
6.8 \\
6.8 \\
6.8\end{array}$ & $\begin{array}{l}7.1 \\
7.1 \\
7.1 \\
7.1 \\
7.1\end{array}$ \\
\hline $\begin{array}{l}21 \ldots \ldots \ldots \\
22 \ldots \ldots \\
23 \ldots \ldots \\
24 \ldots \ldots \\
25 \ldots \ldots\end{array}$ & $\begin{array}{l}20.5 \\
20.5 \\
20.1 \\
20.0 \\
20.6\end{array}$ & $\begin{array}{l}15.5 \\
15.1 \\
14.9 \\
14.7 \\
14.4\end{array}$ & $\begin{array}{l}13.4 \\
13.4 \\
13.9 \\
14.9 \\
16.0\end{array}$ & $\begin{array}{l}22.1 \\
22.6 \\
22.4 \\
22.2 \\
22.0\end{array}$ & $\begin{array}{l}9.8 \\
9.6 \\
9.5 \\
9.4 \\
9.3\end{array}$ & $\begin{array}{l}8.5 \\
8.5 \\
8.5 \\
8.6 \\
8.6\end{array}$ & $\begin{array}{l}7.6 \\
7.5 \\
7.4 \\
7.4 \\
7.3\end{array}$ & $\begin{array}{l}6.9 \\
7.0 \\
7.0 \\
7.0 \\
7.0\end{array}$ & $\begin{array}{l}6.7 \\
6.7 \\
6.7 \\
6.7 \\
6.7\end{array}$ & $\begin{array}{l}6.8 \\
6.8 \\
6.9 \\
6.9 \\
7.0\end{array}$ & $\begin{array}{l}7.1 \\
7.1 \\
7.1 \\
7.1 \\
7.1\end{array}$ \\
\hline 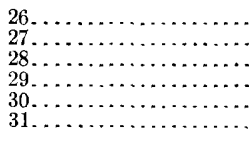 & $\begin{array}{r}21.7 \\
22.1 \\
22.0 \\
21.8 \\
\cdots \\
\cdots\end{array}$ & $\begin{array}{l}14.3 \\
14.6 \\
15.0 \\
15.6 \\
15.9 \\
16.1\end{array}$ & $\begin{array}{l}18.6 \\
19.7 \\
21.1 \\
20.9 \\
20.7 \\
\ldots \ldots .\end{array}$ & $\begin{array}{l}21.9 \\
21.4 \\
20.5 \\
19.7 \\
19.0 \\
17.9\end{array}$ & $\begin{array}{r}9.2 \\
9.1 \\
9.0 \\
9.0 \\
9.6 \\
\cdots . . .\end{array}$ & $\begin{array}{l}8.5 \\
8.5 \\
8.4 \\
8.3 \\
8.2 \\
8.1\end{array}$ & $\begin{array}{l}7.3 \\
7.2 \\
7.2 \\
7.2 \\
7.1 \\
7.4\end{array}$ & $\begin{array}{r}7.0 \\
7.0 \\
7.0 \\
7.0 \\
7.0 \\
\ldots . .\end{array}$ & $\begin{array}{l}6.7 \\
6.7 \\
6.7 \\
6.7 \\
6.7 \\
6.7\end{array}$ & $\begin{array}{r}7.0 \\
7.1 \\
7.1 \\
7.1 \\
7.1 \\
. .2\end{array}$ & $\begin{array}{l}7.1 \\
7.1 \\
7.1 \\
7.1 \\
7.1 \\
7.1\end{array}$ \\
\hline
\end{tabular}

22110 - IRR $245-10-8$ 


\section{SANGAMON RIVER NEAR CHANDLERVILLE, ILL.}

This station is located at the highway bridge about 1 mile west of the town of Chandlerville, Ill. It was established February 9, 1908, for the purpose of collecting data for use in studying drainage and flood-control problems. It was discontinued December 31, 1908, because it was found that the flood flow could not be measured, as part of the flow passed around the section at high water.

No tributaries enter near the station. The drainage area above the section is about 5,070 square miles.

The low-water fall between this point and Illinois River is about 20 feet; the Illinois rises about 22 feet above low water, and therefore there is liable to be backwater effect at this station from Illinois River.

The gage datum has not been changed. The records are reliable and accurate. Sufficient data were not obtained to enable the determination of the daily and monthly discharge.

Discharge measurements of Sangamon River near Chandlerville, Ill., in 1908.

\begin{tabular}{|c|c|c|c|c|c|}
\hline Date. & Hydrographer. & Width. & $\begin{array}{l}\text { Area of } \\
\text { section. }\end{array}$ & $\begin{array}{c}\text { Gage } \\
\text { height. }\end{array}$ & $\begin{array}{l}\text { Dis- } \\
\text { charge. }\end{array}$ \\
\hline $\begin{array}{l}\text { July } 30 \ldots \ldots \ldots \\
\text { November } 7 \ldots . . .\end{array}$ & 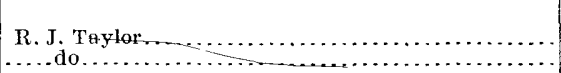 & $\begin{array}{r}\text { Feet. } \\
140 \\
110\end{array}$ & $\begin{array}{r}S q . f t . \\
1,380 \\
872\end{array}$ & $\begin{array}{c}\text { Feet. } \\
4.6 \\
2.17\end{array}$ & $\begin{array}{r}S c c .-f t . \\
1,150 \\
368\end{array}$ \\
\hline
\end{tabular}

Daily gage height, in feet, of Sangamon River near Chandlerville, Ill., for 1908.

[Mrs. Frank Long, observer.]

\begin{tabular}{|c|c|c|c|c|c|c|c|c|c|c|c|}
\hline Day. & Feb. & Mar. & Apr. & May. & June. & July. & Aug. & Sept. & oct. & Nov. & Dec. \\
\hline $\begin{array}{l}1 \ldots \ldots \ldots \\
2 \ldots \ldots \ldots \\
3 \ldots \ldots \ldots \\
4 \ldots \ldots \\
5 \ldots \ldots \ldots\end{array}$ & $\begin{array}{l}\ldots \ldots \\
\cdots \ldots \ldots \\
\cdots \ldots\end{array}$ & $\begin{array}{l}13.5 \\
13.5 \\
13.3 \\
13.25 \\
13.3\end{array}$ & $\begin{array}{l}10.3 \\
10.2 \\
10.0 \\
10.1 \\
10.2\end{array}$ & $\begin{array}{l}13.0 \\
12.9 \\
12.7 \\
12.8 \\
13.0\end{array}$ & $\begin{array}{l}13.0 \\
12.7 \\
12.2 \\
11.5 \\
11.0\end{array}$ & $\begin{array}{l}5.8 \\
5.9 \\
6.0 \\
6.2 \\
6.4\end{array}$ & $\begin{array}{l}4.1 \\
4.0 \\
3.9 \\
3.8 \\
3.7\end{array}$ & $\begin{array}{l}3.0 \\
3.3 \\
3.3 \\
3.0 \\
2.9\end{array}$ & $\begin{array}{l}2.0 \\
2.0 \\
1.9 \\
1.9 \\
1.9\end{array}$ & $\begin{array}{l}2.2 \\
2.2 \\
2.2 \\
2.2 \\
2.2\end{array}$ & $\begin{array}{l}2.2 \\
2.2 \\
2.2 \\
2.2 \\
2.2\end{array}$ \\
\hline $\begin{array}{r}6 \ldots \ldots \ldots \\
7 \ldots \ldots \\
8 \ldots \ldots \\
9 \ldots \ldots \\
10 \ldots \ldots\end{array}$ & $\begin{array}{l}11.3 \\
11.5\end{array}$ & $\begin{array}{l}13.2 \\
13.2 \\
13.2 \\
13.2 \\
13.1\end{array}$ & $\begin{array}{l}10.1 \\
10.1 \\
10.2 \\
10.3 \\
10.6\end{array}$ & $\begin{array}{l}13.5 \\
14.2 \\
14.8 \\
14.9 \\
15.1\end{array}$ & $\begin{array}{r}10.6 \\
10.2 \\
10.0 \\
9.8 \\
9.5\end{array}$ & $\begin{array}{l}6.1 \\
6.1 \\
6.3 \\
6.6 \\
6.9\end{array}$ & $\begin{array}{l}3.7 \\
3.6 \\
3.5 \\
3.5 \\
3.5\end{array}$ & $\begin{array}{l}2.8 \\
2.5 \\
2.5 \\
2.5 \\
2.5\end{array}$ & $\begin{array}{l}1.9 \\
1.9 \\
1.9 \\
1.9 \\
1.9\end{array}$ & $\begin{array}{l}2.2 \\
2.2 \\
2.2 \\
2.2 \\
2.2\end{array}$ & $\begin{array}{l}2.2 \\
2.2 \\
2.2 \\
2.2 \\
2.2\end{array}$ \\
\hline $\begin{array}{l}11 \ldots \ldots \\
12 \ldots \ldots \\
13 \ldots \ldots \\
14 \ldots \ldots \\
15 \ldots \ldots\end{array}$ & $\begin{array}{l}11.4 \\
11.25 \\
11.25 \\
11.7 \\
12.0\end{array}$ & $\begin{array}{l}13.0 \\
13.0 \\
13.0 \\
13.0 \\
12.9\end{array}$ & $\begin{array}{l}10.9 \\
11.0 \\
11.1 \\
11.0 \\
11.1\end{array}$ & $\begin{array}{l}15.2 \\
15.5 \\
16.0 \\
16.3 \\
16.5\end{array}$ & $\begin{array}{l}9.1 \\
9.0 \\
8.9 \\
8.9 \\
8.6\end{array}$ & $\begin{array}{l}6.5 \\
6.1 \\
5.8 \\
5.6 \\
5.5\end{array}$ & $\begin{array}{l}3.3 \\
3.2 \\
3.4 \\
3.3 \\
3.2\end{array}$ & $\begin{array}{l}2.5 \\
2.4 \\
2.2 \\
2.2 \\
2.2\end{array}$ & $\begin{array}{l}1.9 \\
1.9 \\
1.9 \\
1.9 \\
1.8\end{array}$ & $\begin{array}{l}2.2 \\
2.2 \\
2.2 \\
2.2 \\
2.2\end{array}$ & $\begin{array}{l}2.2 \\
2.2 \\
2.2 \\
2.2 \\
2.2\end{array}$ \\
\hline $\begin{array}{l}16 \ldots \ldots \\
17 \ldots \ldots \\
18 \ldots \ldots \\
19 \ldots \ldots \\
20 \ldots \ldots\end{array}$ & $\begin{array}{l}12.2 \\
12.5 \\
12.9 \\
13.4 \\
13.3\end{array}$ & $\begin{array}{l}12.8 \\
12.6 \\
12.5 \\
12.2 \\
11.8\end{array}$ & $\begin{array}{l}11.0 \\
11.0 \\
11.2 \\
11.0 \\
10.8\end{array}$ & $\begin{array}{l}16.5 \\
16.0 \\
15.2 \\
14.8 \\
14.4\end{array}$ & $\begin{array}{l}8.2 \\
8.0 \\
7.7 \\
7.5 \\
7.4\end{array}$ & $\begin{array}{l}5.5 \\
5.5 \\
5.4 \\
5.3 \\
5.3\end{array}$ & $\begin{array}{l}3.2 \\
3.2 \\
3.1 \\
3.0 \\
3.0\end{array}$ & $\begin{array}{l}2.2 \\
2.2 \\
2.2 \\
2.2 \\
2.0\end{array}$ & $\begin{array}{l}1.8 \\
1.8 \\
1.8 \\
1.8 \\
1.8\end{array}$ & $\begin{array}{l}2.2 \\
2.2 \\
2.2 \\
2.2 \\
2.2\end{array}$ & $\begin{array}{l}2.2 \\
2.2 \\
2.2 \\
2.2 \\
2.2\end{array}$ \\
\hline $\begin{array}{l}21 \ldots \ldots \ldots \\
22 \ldots \ldots \\
23 \ldots \ldots \\
24 \ldots \ldots \\
25 \ldots \ldots \\
\ldots\end{array}$ & $\begin{array}{l}13.0 \\
12.8 \\
12.5 \\
12.3 \\
12.5\end{array}$ & $\begin{array}{l}11.5 \\
11.25 \\
11.0 \\
10.8 \\
10.6\end{array}$ & $\begin{array}{l}10.6 \\
10.3 \\
10.2 \\
10.2 \\
11.2\end{array}$ & $\begin{array}{l}14.1 \\
14.1 \\
14.0 \\
13.8 \\
13.6\end{array}$ & $\begin{array}{l}7.2 \\
7.1 \\
6.9 \\
6.7 \\
6.4\end{array}$ & $\begin{array}{l}5.1 \\
5.0 \\
4.8 \\
4.8 \\
4.6\end{array}$ & $\begin{array}{l}2.9 \\
2.9 \\
2.9 \\
2.8 \\
2.7\end{array}$ & $\begin{array}{l}2.3 \\
2.0 \\
2.0 \\
2.0 \\
2.0\end{array}$ & $\begin{array}{l}1.8 \\
1.8 \\
1.8 \\
1.8 \\
1.8\end{array}$ & $\begin{array}{l}2.2 \\
2.2 \\
2.2 \\
2.3 \\
2.3\end{array}$ & $\begin{array}{l}2.1 \\
2.1 \\
2.0 \\
2.0 \\
1.9\end{array}$ \\
\hline $\begin{array}{l}26 \ldots \ldots \\
27 \ldots \ldots \\
28 \ldots \ldots \\
29 \ldots \ldots \\
30 \ldots \ldots \\
31 \ldots \ldots \\
\ldots \ldots\end{array}$ & $\begin{array}{l}12.6 \\
12.9 \\
13.0 \\
13.25\end{array}$ & $\begin{array}{l}10.5 \\
10.3 \\
10.1 \\
10.0 \\
10.0 \\
10.3\end{array}$ & $\begin{array}{l}12.0 \\
12.7 \\
13.0 \\
13.1 \\
13.1\end{array}$ & $\begin{array}{l}13.4 \\
13.1 \\
13.0 \\
13.0 \\
13.0 \\
13.0\end{array}$ & $\begin{array}{l}6.2 \\
6.1 \\
6.0 \\
5.9 \\
5.8 \\
\ldots .\end{array}$ & $\begin{array}{l}4.5 \\
4.9 \\
5.0 \\
4.8 \\
4.5 \\
4.4\end{array}$ & $\begin{array}{l}2.7 \\
2.6 \\
2.6 \\
2.6 \\
2.6 \\
2.8\end{array}$ & $\begin{array}{l}2.0 \\
2.0 \\
2.0 \\
2.0 \\
2.0\end{array}$ & $\begin{array}{l}2.1 \\
2.2 \\
2.2 \\
2.2 \\
2.2 \\
2.2\end{array}$ & $\begin{array}{l}2.3 \\
2.2 \\
2.2 \\
2.2 \\
2.2\end{array}$ & $\begin{array}{l}1.9 \\
1.9 \\
1.9 \\
1.9 \\
2.0 \\
2.0\end{array}$ \\
\hline
\end{tabular}


SOUTH FORK OF SANGAMON RIVER NEAR TAYLORVILLE, ILL.

This station, which is located at the Wabash Railroad bridge, about $3 \frac{1}{2}$ miles southwest of Taylorville, Ill., was established February 11,1908 , to obtain data to be used in studying drainage, water supply, and flood control.

Bear Creek, a small tributary, enters the stream from the southwest, a few miles below the station. The drainage area above the section is about 412 square miles.

The datum of the gage has not been changed. The records are reliable and accurate.

The daily and monthly discharge has not been determined on account of insufficient data.

Discharge measurements of South Fork of Sangamon River near Taylorville, Ill., in 1908.

\begin{tabular}{|c|c|c|c|c|c|}
\hline Date. & Hydrographer. & width. & $\begin{array}{l}\text { Area of } \\
\text { section. }\end{array}$ & $\begin{array}{l}\text { Gage } \\
\text { height. }\end{array}$ & $\begin{array}{c}\text { Dis- } \\
\text { charge. }\end{array}$ \\
\hline $\begin{array}{l}\text { March } 25 . \\
\text { June } 9 . .\end{array}$ & $\begin{array}{l}\text { R. J. Taylor. } \\
\ldots . \text { do . . }\end{array}$ & $\begin{array}{r}\text { Feet. } \\
122 \\
85\end{array}$ & $\begin{array}{r}S q \cdot f t . \\
484 \\
345\end{array}$ & $\begin{array}{c}\text { Feet. } \\
4.55 \\
3.3\end{array}$ & $\begin{array}{r}\text { Sec.-ft. } \\
159 \\
88\end{array}$ \\
\hline
\end{tabular}

Daily gage height, in feet, of South Fork of Sangamon River near Taylorville, Ill., for 1908 .

[R. J. Hanon, observer.]

\begin{tabular}{|c|c|c|c|c|c|c|c|c|c|c|c|}
\hline Day. & Feb. & Mar. & Apr. & May. & June. & July. & Aug. & Sept. & Oct. & Nov. & Dec. \\
\hline$\frac{1 .}{2 .}$ & $\cdots$ & $\begin{array}{l}7.0 \\
7.6 \\
8.2 \\
8.2 \\
7.8\end{array}$ & $\begin{array}{l}6.9 \\
6.7 \\
7.2 \\
7.4 \\
7.0\end{array}$ & $\begin{array}{r}7.0 \\
6.3 \\
6.6 \\
6.9 \\
11.2\end{array}$ & $\begin{array}{l}4.8 \\
4.7 \\
4.6 \\
4.4\end{array}$ & & $\begin{array}{r}1.1 \\
1.0 \\
.9 \\
.9 \\
.8\end{array}$ & $\begin{array}{l}1.1 \\
.9 \\
.7 \\
.6\end{array}$ & $\begin{array}{l}0.6 \\
.6 \\
.5 \\
.5 \\
.5\end{array}$ & $\begin{array}{l}0.6 \\
.6 \\
.6 \\
.6 \\
.6\end{array}$ & $\begin{array}{l}1 . \\
1 . \\
1 .\end{array}$ \\
\hline $\begin{array}{r}6 . . \\
7 . . \\
8 . . \\
9 . . \\
10 . .\end{array}$ & $\begin{array}{l} \\
\cdots \\
\cdots \\
\cdots \\
\cdots\end{array}$ & $\begin{array}{l}7.9 \\
8.0 \\
8.1 \\
8.5 \\
8.0\end{array}$ & $\begin{array}{l}6.7 \\
6.8 \\
7.0 \\
7.0 \\
7.5\end{array}$ & $\begin{array}{l}12.8 \\
12.4 \\
12.3 \\
12.1 \\
10.0\end{array}$ & $\begin{array}{l}\text { 3. } \\
\text { 3.2 } \\
\text { 3. } 3 \\
\text { 3. } 4\end{array}$ & & $\begin{array}{l}.9 \\
.9 \\
.8 \\
.8 \\
.9\end{array}$ & $\begin{array}{l}.7 \\
.6 \\
.6 \\
.6 \\
.6\end{array}$ & $\begin{array}{l}.5 \\
.5 \\
.5 \\
.5 \\
.5\end{array}$ & $\begin{array}{l}.6 \\
.6 \\
.6 \\
.7 \\
.7\end{array}$ & $\begin{array}{l}1.0 \\
1.0 \\
1.0\end{array}$ \\
\hline & $\begin{array}{l}7.0 \\
6.2 \\
5.8 \\
6.4 \\
7.0\end{array}$ & $\begin{array}{l}7.8 \\
7.8 \\
7.4 \\
6.9 \\
6.4\end{array}$ & $\begin{array}{l}7.4 \\
7.1 \\
6.6 \\
6.2 \\
5.8\end{array}$ & $\begin{array}{l}9.0 \\
9.3 \\
9.1 \\
8.6\end{array}$ & $\begin{array}{l}3.4 \\
3.3 \\
3.2 \\
2.8 \\
3.3\end{array}$ & & $\begin{array}{l}.9 \\
.9 \\
.9 \\
.9 \\
.9\end{array}$ & $\begin{array}{l}.6 \\
.5 \\
.5 \\
.5 \\
.5\end{array}$ & $\begin{array}{l}.4 \\
.4 \\
.4 \\
.4 \\
.4\end{array}$ & $\begin{array}{l}.7 \\
.7 \\
.8 \\
.8 \\
.8\end{array}$ & $\begin{array}{r}1.0 \\
1.0 \\
1.0 \\
.9\end{array}$ \\
\hline & $\begin{array}{l}9.3 \\
8.9 \\
98.2 \\
7.7\end{array}$ & $\begin{array}{l}6.0 \\
5.8 \\
5.4 \\
5.0 \\
5.3\end{array}$ & $\begin{array}{l}5.5 \\
5.1 \\
4.9 \\
4.8 \\
4.8\end{array}$ & … & $\begin{array}{l}2.9 \\
2.7 \\
2.7 \\
2.5 \\
2.4\end{array}$ & & $\begin{array}{l}.8 \\
.8 \\
.8 \\
.8\end{array}$ & $\begin{array}{l}.5 \\
.5 \\
.5 \\
.5 \\
.5\end{array}$ & $\begin{array}{l}.4 \\
.4 \\
.5 \\
.5 \\
.5\end{array}$ & $\begin{array}{l}.8 \\
.8 \\
.8 \\
.8\end{array}$ & 1 \\
\hline & $\begin{array}{l}7.3 \\
66.9 \\
6.7 \\
6.7 \\
7.6\end{array}$ & $\begin{array}{l}5.1 \\
4.9 \\
4.7 \\
4.6 \\
4.5\end{array}$ & $\begin{array}{l}4.6 \\
4.3 \\
4.1 \\
6.9 \\
7.7\end{array}$ & $\begin{array}{l}8.9 \\
8.1\end{array}$ & $\begin{array}{l}2.5 \\
2.3 \\
2.2 \\
2.0 \\
1.9\end{array}$ & $\cdots$. & $\begin{array}{l}.7 \\
.6 \\
.6 \\
.6 \\
.5\end{array}$ & $\begin{array}{l}.4 \\
.4 \\
.5 \\
.6 \\
.6\end{array}$ & .6 & $\begin{array}{r}.8 \\
.9 \\
1.1 \\
1.2 \\
1.3\end{array}$ & $\begin{array}{r}.9 \\
.9 \\
.9\end{array}$ \\
\hline $\begin{array}{l}26 \ldots \ldots \ldots \\
27 \ldots \ldots \ldots \\
28 \ldots \ldots \ldots \\
29 \ldots \ldots \ldots \\
30 \ldots \ldots \ldots \\
31 \ldots \ldots \ldots \\
\end{array}$ & $\begin{array}{r}9.9 \\
10.3 \\
9.5 \\
8.6\end{array}$ & $\begin{array}{l}4.5 \\
4.1 \\
4.2 \\
4.6 \\
4.6 \\
4.5\end{array}$ & $\begin{array}{l}8.0 \\
8.3 \\
8.2 \\
8.0 \\
7.6\end{array}$ & $\begin{array}{r}7.7 \\
6.9 \\
6.8 \\
6.7 \\
\hdashline .9\end{array}$ & $\begin{array}{l}1.8 \\
1.8 \\
1.6 \\
1.9 \\
1.8\end{array}$ & $\begin{array}{r}1.4 \\
1.3 \\
1.1\end{array}$ & $\begin{array}{r}.5 \\
.5 \\
.4 \\
2.4 \\
1.6 \\
1.3\end{array}$ & $\begin{array}{l}.6 \\
.7 \\
.7 \\
.6 \\
.6\end{array}$ & $\begin{array}{l}.9 \\
.9 \\
.8 \\
.7 \\
.6 \\
.6\end{array}$ & $\begin{array}{r}1.1 \\
1.1 \\
.9 \\
.9 \\
1.4\end{array}$ & $\begin{array}{r}99 \\
.8\end{array}$ \\
\hline
\end{tabular}




\section{SALT CREEK NEAR KENNEY, ILL.}

This station, which is located at the highway bridge a short distance below the Vandalia Railroad bridge, about 3 miles west of Kenney, Ill., was established February 14, 1908, to collect data for use in studies of drainage and flood-control problems. This stream is a tributary of Sangamon River.

No tributaries enter near the station. The drainage area above the section is about 398 square miles.

The datum of the gage has not been changed. The records are reliable and accurate.

The daily and monthly discharge has not yet been determined because of insufficient data.

Discharge measurements of Salt Creek near Kenney, Ill., in 1908.

\begin{tabular}{|c|c|c|c|c|c|}
\hline Date. & Hydrographer. & Width. & $\begin{array}{l}\text { Area of } \\
\text { section. }\end{array}$ & $\begin{array}{c}\text { Gage } \\
\text { height. }\end{array}$ & $\begin{array}{c}\text { Dis- } \\
\text { charge. }\end{array}$ \\
\hline $\begin{array}{l}\text { May } 8 \ldots \\
\text { July } 28 .\end{array}$ & $\begin{array}{c}\text { R. J. Taylor. } \\
\ldots \text {. do }\end{array}$ & $\begin{array}{r}\text { Feet. } \\
157 \\
107\end{array}$ & $\begin{array}{r}S q . f t . \\
1,280 \\
178\end{array}$ & $\begin{array}{r}\text { Feet. } \\
10.5 \\
2.1\end{array}$ & $\begin{array}{r}\text { Sec.-ft. } \\
3,240 \\
64\end{array}$ \\
\hline
\end{tabular}

Daily gage height, in feet, of Salt Creek near Kenney, Ill., for 1908.

[Chris McDermott, observer.]

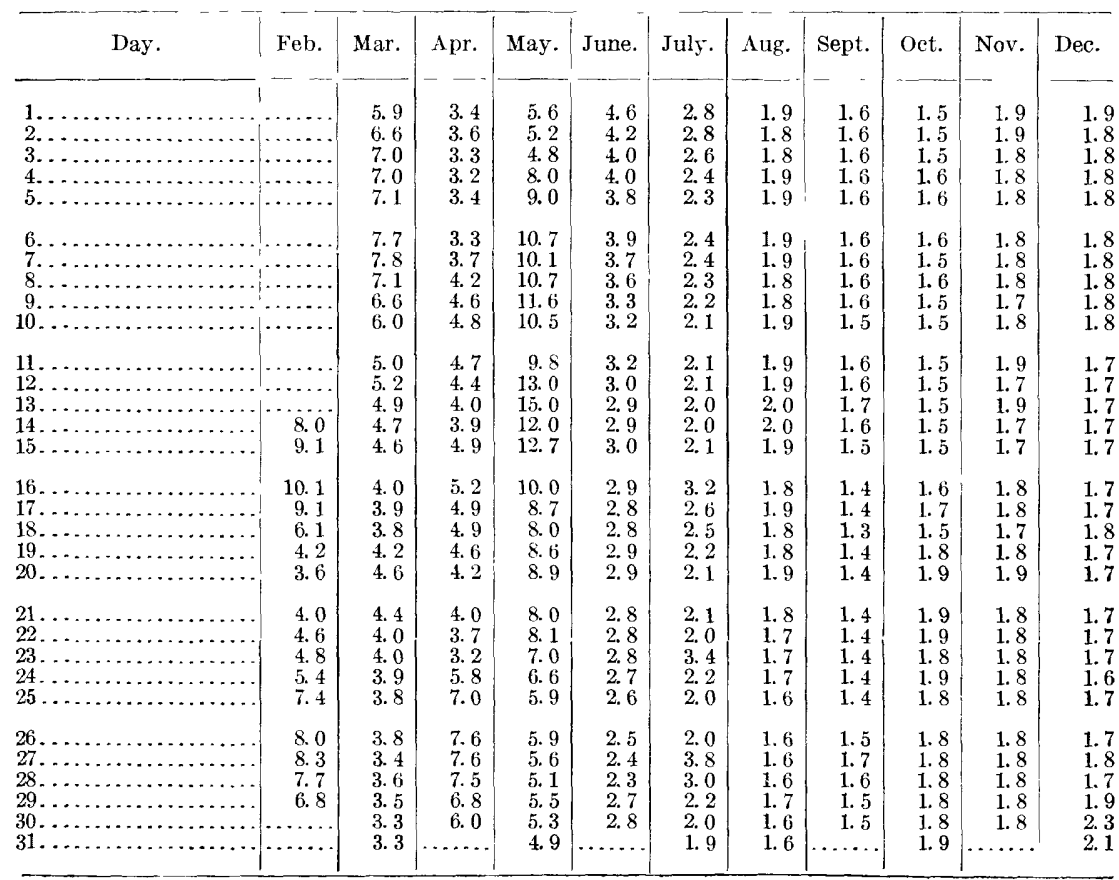




\section{KASKASKIA RIVER DRAINAGE BASIN.}

DESCRIPTION,

Kaskaskia River, also called the Okaw, lies wholly in the State of Illinois. The river rises in the center of Champaign County, flows southwestward, and empties into the Mississippi River in Randolph County near the city of Chester, Ill. It is about 190 miles in length, not following the bends, but as it is very crooked, its length by course is not far from 400 miles. The total drainage area is about 5,710 square miles. It has few tributaries worthy of mention, the most important being Shoal and Silver Creeks, which enter from the north at the lower part of the river.

The drainage basin is long and comparatively narrow, the average width being about 30 miles, the maximum width about 60 miles. The ground is low, level, or undulating, and in consequence the slope of the river is small. The sources of the river are about 740 feet and its mouth about 350 feet above sea level. The soil is mostly black loam. In the lower portion of the drainage area the soil gradually changes to a yellowish brown clay. The only rock exposure of any extent along this stream is found about 20 miles above Shelbyville. In this 15 or 20 mile section the banks and bed are largely of limestone or sandstone; elsewhere they are mostly soft soil with some gravel.

The basin contains no forested areas. The annual rainfall is about 40 inches. As a rule the winters are mild.

Possibilities for storage have not been investigated to any extent. Opportunities for important water-power development are entirely lacking.

Because of the lowness of its drainage area, the basin affords little ground storage. During wet weather the ground-water plane rises to the surface, and the rains run off into the streams very quickly, producing very sudden rises and floods; in dry weather, as there is little or no ground water stored, the flow of the stream becomes very small and in some places dries up entirely. The banks of the river are low, and in times of floods large areas are covered with water, delaying the planting of crops and at times destroying growing crops. Storage possibilities, land drainage, and flood control are subjects of considerable importance in this basin.

The following gaging stations have been established and maintained in this drainage basin:

Kaskaskia River near Arcola, Ill., 1908.

Kaskaskia River at Shelbyville, Ill., 1908.

Kaskaskia River at Vandalia, Ill., 1908.

Kaskaskia River at Carlyle, I11., 1908.

Silver Creek near Lebanon, Ill., 1908. 
KASKASKIA RIVER NEAR ARCOLA, ILL.

This station, which is located at the highway bridge, known as Bagdad Bridge, about 4 miles west of the town of Arcola, Ill., was established April 11, 1908, to obtain data for use in studies of drainage, flood protection, and storage problems.

Lake Fork enters from the west 3 or 4 miles above the gaging station. The drainage area above the station is about 356 square miles.

The datum of the gage has remained unchanged. The records are reliable and accurate. Sufficient data have not yet been obtained to determine the daily and monthly discharge.

Discharge measurements of Kaskaskia River near Arcola, Ill., in 1908.

\begin{tabular}{|c|c|c|c|c|c|}
\hline Date. & Hydrographer. & Width. & $\begin{array}{l}\text { Area of } \\
\text { section. }\end{array}$ & $\begin{array}{c}\text { Gage } \\
\text { height. }\end{array}$ & $\begin{array}{l}\text { Dis- } \\
\text { charge. }\end{array}$ \\
\hline $\begin{array}{l}\text { April } 29 . . \\
\text { July } 24 \ldots\end{array}$ & 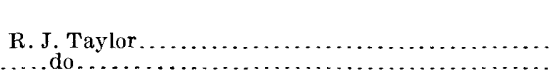 & $\begin{array}{l}\text { Feet. } \\
226 \\
68.5\end{array}$ & $\begin{array}{r}\text { Sq. } f t . \\
1.180 \\
75\end{array}$ & \begin{tabular}{c|} 
Feet. \\
10.0 \\
2.75
\end{tabular} & $\begin{array}{r}\text { Sec. }-f t . \\
1,250 \\
\mathbf{4 4}\end{array}$ \\
\hline
\end{tabular}

Daily gage height, in feet, of Kaskaskia River near Arcola, Ill., for 1908.

[Lawrence L. Pfeifer, observer.]

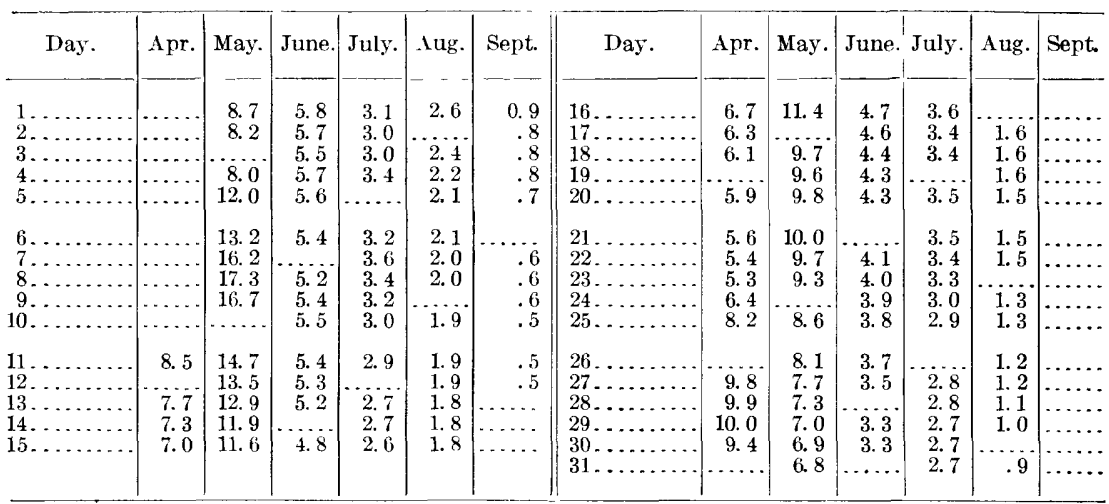

Note.-No flow from August 31 to December 31 .

KASKASKIA RIVER AT SHELBYVILLE, ILL.

This station is located at the highway bridge over Kaskaskia River, a short distance above the Chicago and Eastern Illinois Railroad bridge at Shelbyville, III. It was established February 28, 1908 , to obtain data for use in studying drainage and flood-control problems.

No important tributaries enter the stream near Shelbyville. The drainage area above this point is about 983 square miles. 
The station has not been maintained long enough to know definitely about ice conditions. The gage heights may be affected during high stages by backwater caused by lodging of drift at the two railroad bridges below the station.

The datum of the gage has remained unchanged. The records are reliable and accurate. Sufficient data are not yet available for the determination of daily and monthly discharge.

Discharge measurements of Kaskaskia River at Shelbyville, Ill., in 1908.

\begin{tabular}{|c|c|c|c|c|c|}
\hline Date. & Hydrographer. & Width. & $\begin{array}{l}\text { Area of } \\
\text { section. }\end{array}$ & $\begin{array}{c}\text { Gage } \\
\text { height. }\end{array}$ & $\begin{array}{c}\text { Dis- } \\
\text { charge. }\end{array}$ \\
\hline $\begin{array}{l}\text { February } 24 \ldots \\
\text { April } 29 \ldots \ldots \ldots \\
\text { June } 10 \ldots \ldots \ldots \\
\text { July } 21 \ldots \ldots \ldots\end{array}$ & 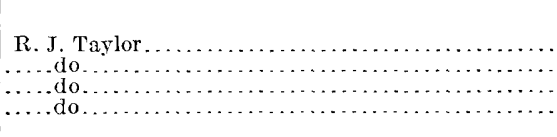 & \begin{tabular}{|r} 
Feet. \\
147 \\
149 \\
113 \\
103
\end{tabular} & $\begin{array}{r}S q . f t . \\
975 \\
1,020 \\
1,010 \\
713\end{array}$ & $\begin{array}{c}\text { Fect. } \\
11.53 \\
12.2 \\
8.7 \\
6.3\end{array}$ & $\begin{array}{r}\text { Sec.-ft. } \\
2,350 \\
2,720 \\
1,080 \\
218\end{array}$ \\
\hline
\end{tabular}

Daily gage height, in feet, of Kaskaskia River at Shelbyville, Ill., for 1908.

[Homer Pounds, observer.]

\begin{tabular}{|c|c|c|c|c|c|c|c|c|c|c|c|}
\hline Day. & Feb. & Mar. & Apr. & May. & June. & July. & A ug. & Sept. & Oct. & Nov. & Dee. \\
\hline $\begin{array}{l}1 . \\
2 . \\
3 \ldots \\
4 \ldots \\
5 .\end{array}$ & & $\begin{array}{l}15.1 \\
15.5 \\
16.4 \\
16.0 \\
15.6\end{array}$ & $\begin{array}{r}11.6 \\
12.8 \\
11.8 \\
11.4 \\
9.9\end{array}$ & $\begin{array}{l}11.8 \\
11.4 \\
10.4 \\
21.2 \\
22.8\end{array}$ & $\begin{array}{l}8.6 \\
8.4 \\
8.3 \\
8.8 \\
8.4\end{array}$ & $\begin{array}{l}6.4 \\
6.3 \\
6.4 \\
6.3 \\
6.3\end{array}$ & $\begin{array}{l}5.8 \\
5.7 \\
5.7 \\
5.6 \\
5.6\end{array}$ & $\begin{array}{l}5.4 \\
5.3 \\
5.3 \\
5.2 \\
5.2\end{array}$ & $\begin{array}{l}5.3 \\
5.2 \\
5.2 \\
5.2 \\
5.1\end{array}$ & \begin{tabular}{l|}
4.9 \\
5.0 \\
5.0 \\
5.1 \\
5.1
\end{tabular} & $\begin{array}{l}5.4 \\
5.4 \\
5.4 \\
5.3 \\
5.3\end{array}$ \\
\hline $\begin{array}{r}6 . \\
7 \ldots \\
8 \\
9 \\
10\end{array}$ & & $\begin{array}{l}15.4 \\
15.8 \\
16.2 \\
16.6 \\
17.0\end{array}$ & $\begin{array}{r}9.6 \\
9.5 \\
11.5 \\
11.7 \\
11.8\end{array}$ & $\begin{array}{l}22.3 \\
22.7 \\
25.8 \\
23.6 \\
21.2\end{array}$ & $\begin{array}{l}8.1 \\
7.8 \\
7.6 \\
8.0 \\
8.4\end{array}$ & $\begin{array}{l}6.4 \\
6.7 \\
6.8 \\
6.9 \\
6.6\end{array}$ & $\begin{array}{l}5.5 \\
5.5 \\
5.5 \\
5.6 \\
5.7\end{array}$ & $\begin{array}{l}5.2 \\
5.2 \\
5.2 \\
5.1 \\
5.1\end{array}$ & $\begin{array}{l}5.1 \\
5.1 \\
5.1 \\
5.1 \\
5.1\end{array}$ & $\begin{array}{l}5.2 \\
5.2 \\
5.2 \\
5.2 \\
5.2\end{array}$ & $\begin{array}{l}5.3 \\
5.3 \\
5.3 \\
5.3 \\
5.4\end{array}$ \\
\hline $\begin{array}{l}11 . \\
12 . \\
13 . \\
14 . \\
15 .\end{array}$ & & $\begin{array}{l}16.8 \\
15.8 \\
14.8 \\
14.2 \\
13.6\end{array}$ & $\begin{array}{l}11.5 \\
11.3 \\
11.1 \\
11.0 \\
10.1\end{array}$ & $\begin{array}{l}20.2 \\
19.5 \\
18.8 \\
17.9 \\
17.0\end{array}$ & $\begin{array}{l}8.3 \\
7.9 \\
7.6 \\
7.5 \\
7.3\end{array}$ & $\begin{array}{l}6.5 \\
6.5 \\
6.3 \\
6.2 \\
6.0\end{array}$ & $\begin{array}{l}5.7 \\
5.6 \\
5.7 \\
5.6 \\
5.6\end{array}$ & $\begin{array}{l}5.0 \\
5.0 \\
5.0 \\
5.0 \\
5.0\end{array}$ & $\begin{array}{l}5.1 \\
5.1 \\
5.1 \\
5.1 \\
5.0\end{array}$ & \begin{tabular}{l|}
5.2 \\
5.2 \\
5.2 \\
5.2 \\
5.2
\end{tabular} & $\begin{array}{l}5.4 \\
5.4 \\
5.4 \\
5.4 \\
5.4\end{array}$ \\
\hline $\begin{array}{l}16 \ldots \ldots \\
17 \ldots \ldots \\
18 \ldots \ldots \\
19 \ldots \ldots \\
20 \ldots \ldots\end{array}$ & & $\begin{array}{l}13.1 \\
11.9 \\
10.9 \\
10.0 \\
10.1\end{array}$ & $\begin{array}{l}9.6 \\
8.9 \\
8.8 \\
8.7 \\
8.6\end{array}$ & $\begin{array}{l}16.4 \\
15.9 \\
15.0 \\
14.9 \\
13.7\end{array}$ & $\begin{array}{l}7.0 \\
6.9 \\
6.7 \\
6.6 \\
6.8\end{array}$ & $\begin{array}{l}6.0 \\
5.9 \\
5.8 \\
6.1 \\
6.1\end{array}$ & $\begin{array}{l}5.5 \\
5.5 \\
5.5 \\
5.4 \\
5.4\end{array}$ & $\begin{array}{l}5.0 \\
5.1 \\
5.1 \\
5.1 \\
5.1\end{array}$ & $\begin{array}{l}5.0 \\
5.0 \\
5.0 \\
5.0 \\
5.0\end{array}$ & $\begin{array}{l}5.3 \\
5.3 \\
5.3 \\
5.3 \\
5.3\end{array}$ & $\begin{array}{l}5.4 \\
5.3 \\
5.3 \\
5.3 \\
5.3\end{array}$ \\
\hline $\begin{array}{l}21 \ldots \ldots \\
22 \ldots \ldots \\
23 \ldots \ldots \\
24 \ldots \ldots \\
25 \ldots \ldots\end{array}$ & 14.2 & $\begin{array}{l}9.7 \\
9.6 \\
9.5 \\
9.4 \\
9.3\end{array}$ & $\begin{array}{r}8.5 \\
8.4 \\
8.3 \\
10.1 \\
10.6\end{array}$ & $\begin{array}{l}12.8 \\
13.7 \\
13.1 \\
12.6 \\
12.0\end{array}$ & $\begin{array}{l}6.7 \\
6.7 \\
6.6 \\
6.5 \\
6.5\end{array}$ & $\begin{array}{l}6.1 \\
6.0 \\
6.0 \\
5.9 \\
5.8\end{array}$ & $\begin{array}{l}5.4 \\
5.3 \\
5.3 \\
5.3 \\
5.3\end{array}$ & $\begin{array}{l}5.1 \\
5.0 \\
5.0 \\
5.0 \\
5.0\end{array}$ & $\begin{array}{l}5.0 \\
5.0 \\
4.9 \\
4.9 \\
4.9\end{array}$ & $\begin{array}{l}5.3 \\
5.4 \\
5.4 \\
5.5 \\
5.5\end{array}$ & $\begin{array}{l}5.3 \\
5.3 \\
5.3 \\
5.3 \\
5.2\end{array}$ \\
\hline $\begin{array}{l}26 \ldots \\
27 . \\
28 . \\
29 . \\
30 \ldots \\
31 \ldots\end{array}$ & $\begin{array}{r}16.4 \\
17.0 \\
16.6 \\
15.3 \\
\ldots \ldots\end{array}$ & $\begin{array}{l}9.0 \\
8.7 \\
8.5 \\
8.9 \\
8.9 \\
8.7\end{array}$ & $\begin{array}{l}11.2 \\
11.8 \\
12.2 \\
12.4 \\
11.9\end{array}$ & $\begin{array}{r}11.5 \\
11.3 \\
10.0 \\
9.8 \\
9.4 \\
9.0\end{array}$ & $\begin{array}{l}6.4 \\
6.3 \\
6.1 \\
6.2 \\
6.3\end{array}$ & $\begin{array}{l}5.8 \\
5.7 \\
5.7 \\
5.6 \\
5.7 \\
5.8\end{array}$ & $\begin{array}{l}5.3 \\
5.3 \\
5.2 \\
5.2 \\
5.3 \\
5.3\end{array}$ & $\begin{array}{l}5.0 \\
5.0 \\
5.1 \\
5.2 \\
5.3\end{array}$ & $\begin{array}{l}5.0 \\
5.0 \\
5.0 \\
4.9 \\
4.9 \\
4.9\end{array}$ & $\begin{array}{l}5.6 \\
5.6 \\
5.5 \\
5.5 \\
5.5\end{array}$ & $\begin{array}{l}5.2 \\
5.2 \\
5.3 \\
5.3 \\
5.4 \\
5.4\end{array}$ \\
\hline
\end{tabular}

KASKASKIA RIVER AT VANDALIA, ILL.

This station, which is located at the highway bridge at the east end of Main street, Vandalia, Ill., was established February 26, 1908, to obtain data for use in studying drainage questions, flood protection, and levee construction. No important tributaries enter the 
river near Vandalia. The drainage area above this point is about 1,880 square miles.

Records have not been kept long enough to know much about ice conditions. The river for some miles above and below Vandalia is leveed. During extreme floods these levees sometimes give way, thus reducing the flood flow; all the water, however, eventually passes the gaging section.

The datum of the gage has remained unchanged. The records are reliable and accurate.

Insufficient data have been collected at this station to allow of the determination of daily and monthly discharge.

Discharge measurements of Kaskaskia River at Vandalia, Ill., in 1908.

\begin{tabular}{|c|c|c|c|c|c|}
\hline Date. & Hydrographer. & Width. & $\begin{array}{l}\text { Area of } \\
\text { section. }\end{array}$ & $\begin{array}{c}\text { Gage } \\
\text { height. }\end{array}$ & $\begin{array}{c}\text { Dis- } \\
\text { charge. }\end{array}$ \\
\hline $\begin{array}{l}\text { February } 26 . . \\
\text { March } 19 . \ldots . \\
\text { March } 20 \ldots \ldots \\
\text { April } 30 \ldots \ldots \\
\text { July } 6 \ldots \ldots \ldots \\
\text { August } 6 \ldots \ldots\end{array}$ & 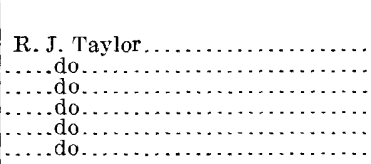 & \begin{tabular}{r|} 
Feet. \\
155 \\
128 \\
128 \\
151 \\
112 \\
106
\end{tabular} & $\begin{array}{r}S q . f t . \\
2,350 \\
1,510 \\
1,430 \\
1,890 \\
713 \\
563\end{array}$ & \begin{tabular}{c|} 
Feet. \\
18.53 \\
10.1 \\
9.6 \\
12.9 \\
3.6 \\
2.3
\end{tabular} & $\begin{array}{r}S e c-f t . \\
6,870 \\
2,400 \\
2,130 \\
3,600 \\
287 \\
84\end{array}$ \\
\hline
\end{tabular}

Daily gage height, in feet, of Kaskaskia River at Vandalia, Ill., for 1908.

[W. F. Radcliff, observer.]

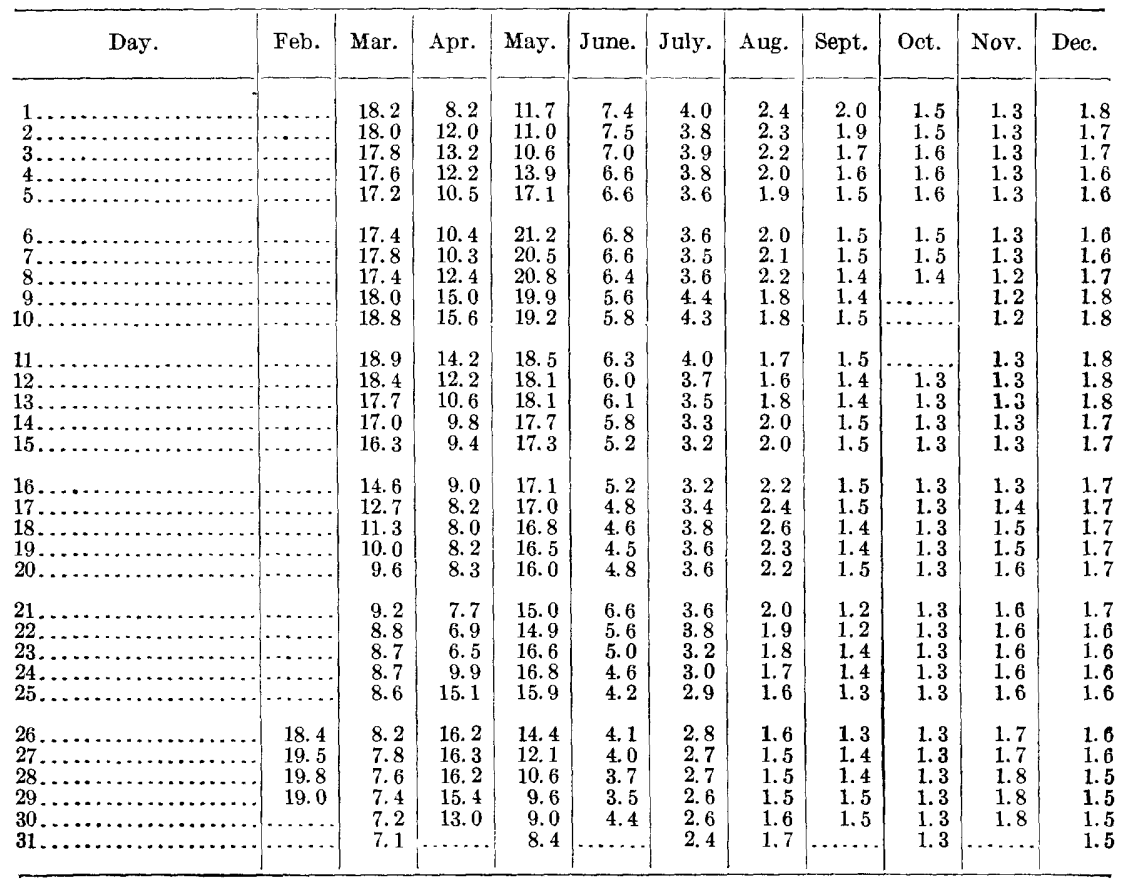


KASKASKIA RIVER AT CARLYLE, ILL.

This station, which is located at the Baltimore and Ohio Southwestern Railroad bridge, about one-fourth mile east of the railroad station at Carlyle, Ill., was established March 2, 1908, to obtain data for use in studying problems of drainage and flood control along this section of the river.

No important tributaries enter within 10 miles above or below the station. The drainage area above the gaging station is about 2,630 square miles.

The station has not been maintained long enough to determine the ice conditions. The river is subject to high floods and extreme low water. The datum of the gage has remained unchanged. The records of the gage heights are reliable and accurate. Low-water discharge figures should be used with caution, as another year's records are needed to verify the measurements made this year. Insufficient data are available for the determination of the daily and monthly discharge.

Discharge measurements of Kaskaskia River at Carlyle, Ill., in 1908.

\begin{tabular}{|c|c|c|c|c|c|}
\hline Date. & Hydrographer. & Width. & $\begin{array}{l}\text { Area of } \\
\text { section. }\end{array}$ & $\begin{array}{c}\text { Gage } \\
\text { height. }\end{array}$ & $\begin{array}{l}\text { Dis- } \\
\text { charge. }\end{array}$ \\
\hline $\begin{array}{l}\text { March } 23 \ldots \ldots . \\
\text { May } 4 \ldots \ldots \ldots \\
\text { July } 8 \ldots \ldots \ldots \\
\text { August } 7 \ldots \ldots \\
\text { September } 24 . \\
\text { October } 22 \ldots .\end{array}$ & 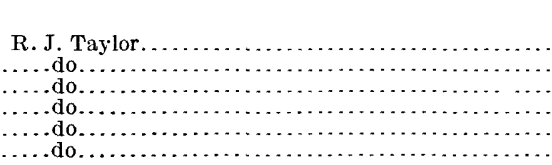 & \begin{tabular}{|r|} 
Fect. \\
196 \\
512 \\
131 \\
124 \\
$\ldots$
\end{tabular} & $\begin{array}{r}S q . f t . \\
1,770 \\
3,770 \\
335 \\
239 \\
\ldots \ldots\end{array}$ & $\begin{array}{l}F c \epsilon t . \\
16.7 \\
21.35 \\
8.1 \\
7.1 \\
5.6 \\
5.6\end{array}$ & \begin{tabular}{|r} 
Sec. $-f t$. \\
2,830 \\
5,360 \\
426 \\
289 \\
$a 62$ \\
$a 32$
\end{tabular} \\
\hline
\end{tabular}

Daily gage height, in feet, of Kaskaskia River at Carlyle, Ill., for 1908.

[Mike Schilling, observer.]

\begin{tabular}{|c|c|c|c|c|c|c|c|c|c|c|}
\hline Day. & Mar. & Apr. & May. & June. & July. & Aug. & Sept. & Oct. & Nov. & Dec. \\
\hline $\begin{array}{l}1 \ldots \\
2 . . \\
3 . . \\
4 . . \\
5 . .\end{array}$ & $\begin{array}{l}23.7 \\
23.6 \\
23.3 \\
23.1\end{array}$ & $\begin{array}{l}13.9 \\
16.1 \\
17.6 \\
18.2 \\
18.5\end{array}$ & $\begin{array}{l}22.2 \\
22.1 \\
21.8 \\
21.3 \\
21.8\end{array}$ & $\begin{array}{l}19.1 \\
15.6 \\
13.3 \\
12.5 \\
11.9\end{array}$ & $\begin{array}{l}8.0 \\
8.2 \\
8.2 \\
8.1 \\
8.0\end{array}$ & $\begin{array}{l}7.5 \\
7.3 \\
7.0 \\
6.8 \\
6.7\end{array}$ & $\begin{array}{l}6.1 \\
6.0 \\
6.0 \\
5.9 \\
5.8\end{array}$ & $\begin{array}{l}5.6 \\
5.6 \\
5.6 \\
5.6 \\
5.6\end{array}$ & $\begin{array}{l}5.6 \\
5.6 \\
5.6 \\
5.6 \\
5.6\end{array}$ & $\begin{array}{l}5.6 \\
5.6\end{array}$ \\
\hline $\begin{array}{r}6 \ldots \\
7 \ldots \\
8 \ldots \\
9 \ldots \\
10 \ldots\end{array}$ & $\begin{array}{l}22.9 \\
22.8 \\
22.8 \\
22.8 \\
23.1\end{array}$ & $\begin{array}{l}18.4 \\
18.0 \\
18.0 \\
19.0 \\
19.9\end{array}$ & $\begin{array}{l}23.1 \\
24.9 \\
29.1 \\
30.8 \\
30.0\end{array}$ & $\begin{array}{l}11.6 \\
11.7 \\
11.2 \\
11.1 \\
11.9\end{array}$ & $\begin{array}{l}8.1 \\
8.1 \\
8.0 \\
8.0 \\
7.7\end{array}$ & $\begin{array}{l}7.1 \\
7.1 \\
7.2 \\
6.9 \\
6.7\end{array}$ & $\begin{array}{l}5.8 \\
5.9 \\
5.9 \\
5.8 \\
5.9\end{array}$ & $\begin{array}{l}5.6 \\
5.6 \\
5.6 \\
5.6 \\
5.6\end{array}$ & $\begin{array}{l}5.6 \\
5.6 \\
5.6 \\
5.6 \\
5.6\end{array}$ & $\begin{array}{l}5.9 \\
5.9 \\
5.9 \\
5.7 \\
5.7\end{array}$ \\
\hline $14 \ldots \ldots$ & $\begin{array}{l}23.6 \\
23.7 \\
23.4 \\
23.3 \\
23.0\end{array}$ & $\begin{array}{l}20.7 \\
21.2 \\
21.5 \\
21.5 \\
21.3\end{array}$ & $\begin{array}{l}28.8 \\
27.3 \\
26.3 \\
25.5 \\
24.9\end{array}$ & $\begin{array}{l}11.0 \\
10.6 \\
10.6 \\
10.5 \\
10.4\end{array}$ & $\begin{array}{l}8.5 \\
8.2 \\
8.0 \\
8.0 \\
7.8\end{array}$ & $\begin{array}{l}6.7 \\
6.5 \\
6.6 \\
6.6 \\
6.5\end{array}$ & $\begin{array}{l}5.7 \\
5.7 \\
5.7 \\
5.7 \\
5.7\end{array}$ & $\begin{array}{l}5.6 \\
5.6 \\
5.6 \\
5.6 \\
5.6\end{array}$ & $\begin{array}{l}5.6 \\
5.6 \\
5.6 \\
5.6 \\
5.6\end{array}$ & $\begin{array}{l}5.7 \\
5.7 \\
5.7 \\
5.7 \\
5.7\end{array}$ \\
\hline $\begin{array}{l}16 . . \\
17 . . \\
18 . . \\
19 . . \\
20 . .\end{array}$ & $\begin{array}{l}22.7 \\
22.4 \\
22.2 \\
21.9 \\
21.6\end{array}$ & $\begin{array}{l}20.5 \\
19.1 \\
17.1 \\
15.9 \\
14.8\end{array}$ & $\begin{array}{l}24.4 \\
24.0 \\
23.6 \\
23.3 \\
23.0\end{array}$ & $\begin{array}{l}9.8 \\
9.7 \\
9.4 \\
9.1 \\
8.9\end{array}$ & $\begin{array}{l}7.6 \\
7.7 \\
7.9 \\
7.8 \\
8.2\end{array}$ & $\begin{array}{l}6.5 \\
6.5 \\
6.4 \\
6.4 \\
6.4\end{array}$ & $\begin{array}{l}5.6 \\
5.7 \\
5.7 \\
5.6 \\
5.7\end{array}$ & $\begin{array}{l}5.6 \\
5.6 \\
5.6 \\
5.6 \\
5.6\end{array}$ & $\begin{array}{l}5.6 \\
5.6 \\
5.6 \\
5.6 \\
5.6\end{array}$ & $\begin{array}{l}5.7 \\
5.7 \\
5.7 \\
5.7 \\
5.7\end{array}$ \\
\hline
\end{tabular}


Daily gage hight, in feet, of Kaskaskia River at Carlyle, Ill., for 1908-Continued.

\begin{tabular}{|c|c|c|c|c|c|c|c|c|c|c|}
\hline I)ay. & Mar. , & Apr. & May. & June. & July. & Aug. & Sept. & Oet. & Nor. & Dec. \\
\hline 21. & 20.8 & 14.0 & 22.7 & 9.3 & 8.1 & 6.3 & 5.7 & 5.6 & 5.6 & 5.7 \\
\hline 22 & 18.3 & 12.8 & 23.1 & 10.3 & 8.6 & 6.1 & 5.6 & 5.6 & 5.6 & 5. 6 \\
\hline 23. & 16.6 & 12.3 & 22.9 & 10.3 & 9.3 & 6.0 & 5.7 & 5.6 & 5.6 & 5.6 \\
\hline $24 \ldots$ & 14.9 & 15.4 & 22.7 & 9.3 & 9.2 & 6.0 & 5.7 & 5.6 & 5.6 & 5.6 \\
\hline $2 \tilde{5} \ldots \ldots \ldots \ldots \ldots$ & 13.6 & 18.1 & 22.5 & 9.0 & 8.3 & 5.9 & 5.6 & 5.6 & 5.6 & 5.6 \\
\hline 26. & 13.1 & 19.9 & 22.2 & 8.6 & 8.5 & 5.9 & 5.6 & 5.6 & 5.6 & 5.6 \\
\hline 27. & 12.6 & 21.2 & 22.0 & $8 . \overline{5}$ & 9.4 & 5.9 & 5.6 & 5.6 & 5.6 & 5.6 \\
\hline 28. & 12.3 & 21.7 & 21.9 & 8.4 & 9.3 & 5.9 & 5.6 & 5.6 & 5.6 & 5.6 \\
\hline $29 \ldots$ & 12.7 & 22.0 & 21.8 & 8.5 & 8.2 & 6.1 & 5.6 & 5.6 & 5.6 & 5.6 \\
\hline $30 \ldots \ldots$ & 12.8 & $2: 2.2$ & 21.8 & 8.3 & 8.0 & 6.5 & 5.6 & 5.6 & 5.6 & 5.6 \\
\hline $31 \ldots \ldots \ldots \ldots \ldots \ldots$ & 12.9 & . & 20.6 & & 7.6 & 6.5 & & 5.6 & $\ldots$ & 5.6 \\
\hline
\end{tabular}

\section{SIIVER CREEK NEAR IEBANON, ILL.}

Silver Creek is a tributary of Kaskaskia River, emptying into it just above New Athens. The gaging station, which is located at the highway bridge about 2 miles west of the town of Lebanon, Ill., was established March 3, 1908, to obtain clata for use in studying drainage and flood-control problems.

No tributaries enter near the gaging station. The drainage area above the station is about 328 square miles.

The datum of the gage has not been changed. The records are reliable and accurate.

Sufficient data have not yet been collected to determine the daily and monthly discharge.

Discharge measurements of Silver ('reek ntar Lebanon, Ill., in 1908.

\begin{tabular}{|c|c|c|c|c|c|}
\hline Date. & 11ydrographer. & Width. & $\begin{array}{l}\text { Area of } \\
\text { section. }\end{array}$ & $\begin{array}{l}\text { Gage } \\
\text { height. }\end{array}$ & $\begin{array}{c}\text { Dis- } \\
\text { charge. }\end{array}$ \\
\hline $\begin{array}{l}\text { March } 21 \ldots \\
\text { May } 2 \ldots \ldots \\
\text { July } 9 \ldots \ldots\end{array}$ & 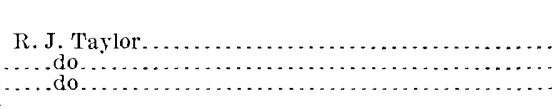 & $\begin{array}{r}\text { Fect. } \\
38 \\
41 \\
35\end{array}$ & $\begin{array}{r}\text { Sq. ft. } \\
111 \\
130 \\
106\end{array}$ & $\begin{array}{c}\text { Feet. } \\
3.5 \\
4.25 \\
3.5\end{array}$ & $\begin{array}{r}\text { Sec.fft. } \\
71 \\
107 \\
58\end{array}$ \\
\hline
\end{tabular}

Daily gage height, in feet, of Silier (reek near Lebanon, Ill., for 1908.

[F. P. Myers, observer.]

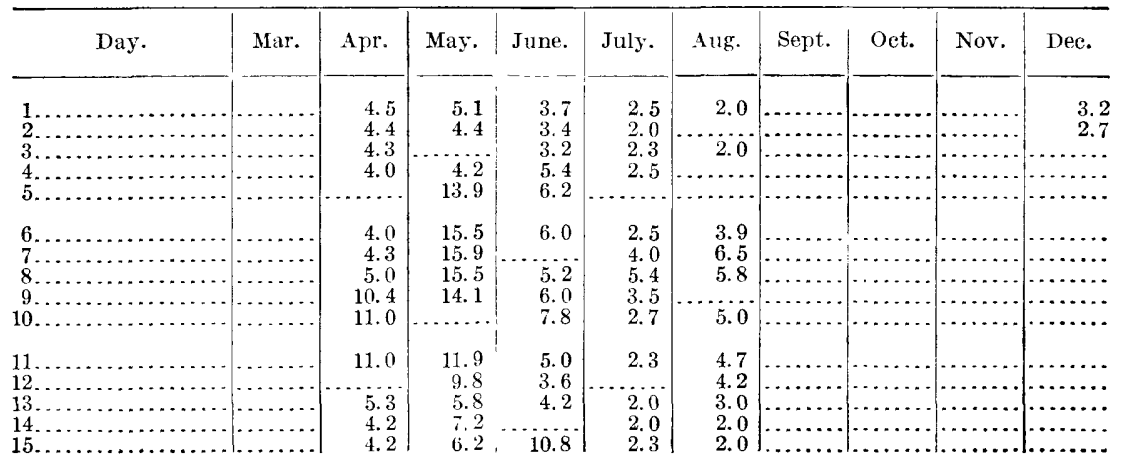


Daily gage height, in feet, of Silier Creek near Lebanon, Ill., for 1908-('ontinued.

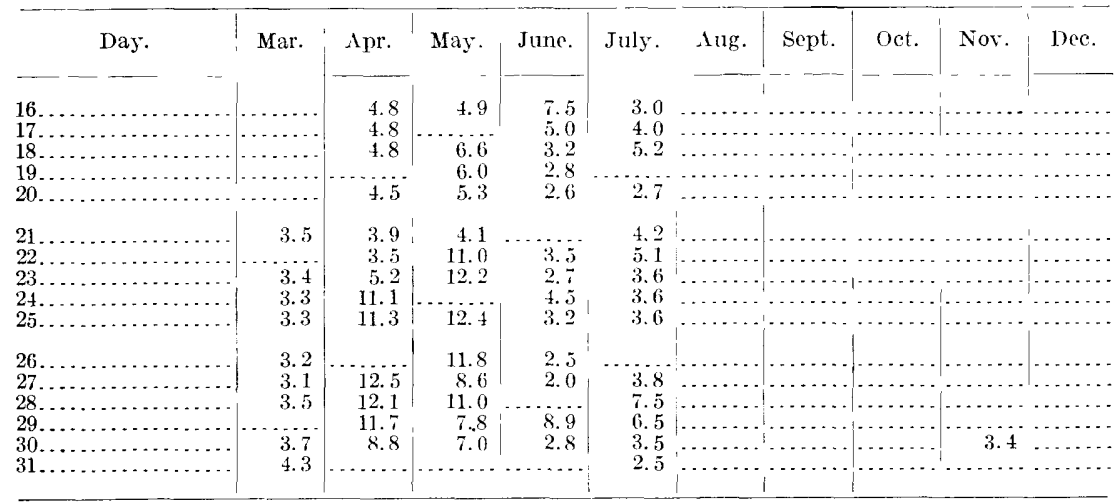

NOTE.-The gage at this station was not set orer the main enannel, hence for stages below 2.0 feet, which occurred August 4 and 5, August 16 to November 29 , and December 3-31, 1908, the stream was dry immediately under the gage. There was water flowing in the main channel for all but about one week during these periods.

\section{BIG MUDDY RIVER DRAINAGE BASIN.}

DESCRIPTION.

The drainage basin of Big Muddy River lies in southern Illinois. The river rises in the northwestern part of Jefferson County, flows southward to the town of Zeigler, in Franklin County, thence westward to Murphysboro, in Jackson County, and then southward to its junction with the Mississippi about 40 miles above Cairo, Ill. Below Zeigler the river is extremely crooked. The total drainage area is about 2,230 square miles. The principal tributaries are Beaucoup Creek, Little Muddy River, Caseys Creek, and Middle Fork Creekall small streams of little importance.

The drainage basin is elliptical in shape, with a major axis about 70 miles long and a minor axis about 50 miles long. The country is level or undulating. The soil is known as "mulatto soil"- - yellowishbrown clay. Winter wheat is the staple crop. The southeastern part is underlain with valuable coal veins and coal mining is carried on quite extensively.

The slope of the river is small. Its sources are about 710 feet, and its mouth is about 310 feet, above sea level. The banks and bed of the stream are soft and insecure.

The area is timberless except for occasional groves and the growth along the banks of the streams.

The mean annual rainfall is about 42 inches. The winters are mild. Ice does not form very thick, and, as a rule, the snowfall is light and does not last long.

Storage possibilities have not been investigated, but owing to the growing demand for water in this section they should receive careful attention. 
The basin offers no opportunities for power development. Like the other rivers in central and southern Illinois, this stream is subject to high floods and very low water. In some localities the high water overflows the land on each bank for 2 or 3 miles; some sections resemble a lake during floods. Backwater from the Mississippi frequently extends to Murphysboro, said to be 60 miles distant following the river, and floods reach the height of 30 feet above low water. It is possible that a canal will be constructed from the Mississippi to the coal fields that lie along the Big Muddy. It is thought that only one lock would be necessary. Canal construction would probably be very simple, as the country is low and the material excavated very soft.

The following gaging stations are being maintained in this drainage basin:

Big Muddy River near (ambon, Ill., 1908.

Beaucoup (reek near Pinckneyville, Ill., 1908.

\section{BIG MUDDY RIVER NEAR CAMBON, ILL.}

This station, which is located at the Chicago, Burlington and Quincy Railroad bridge about 1 mile north of Cambon railroad station near Plumfield, Ill., was established June 16, 1908, to obtain data for use in studying problems of drainage, flood control, and navigation.

The Middle Fork of the Big Muddy enters above the station. The drainage area above the section is about 788 square miles.

The datum of the gage has not been changed. The records are reliable and accurate. The daily and monthly discharge has not been determined because of insufficient data.

The following discharge measurement was made:

June 15. 1908: Width, 41.5 feet; area, 53 square feet; gage height. 2.7 feet; discharge, 19 second-feet.

Daily gage height, in feet, of Big Ifuddy River near Cambon, Ill., for 19g8.

[W. O. Bourland, observer.]

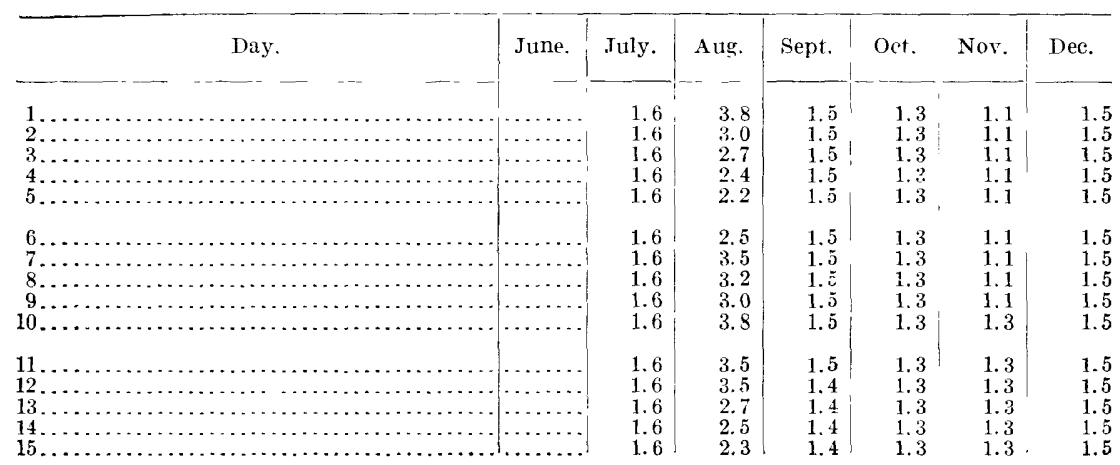


Daily gage height, in feet, of Big Muddy River near Cambon, Ill., for 1908-Continued.

\begin{tabular}{|c|c|c|c|c|c|c|c|}
\hline Day. & June. & July. & Aug. & Sept. & Oct. & Nov. & Dec. \\
\hline 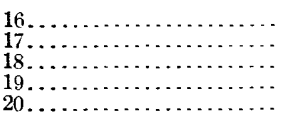 & $\begin{array}{l}2.5 \\
2.3 \\
2.2 \\
2.1 \\
2.0\end{array}$ & $\begin{array}{l}1.6 \\
1.6 \\
1.6 \\
1.6 \\
1.6\end{array}$ & $\begin{array}{l}2.1 \\
1.9 \\
1.9 \\
1.8 \\
1.8\end{array}$ & $\begin{array}{l}1.4 \\
1.4 \\
1.4 \\
1.4 \\
1.4\end{array}$ & $\begin{array}{l}1.3 \\
1.3 \\
1.3 \\
1.3 \\
1.2\end{array}$ & $\begin{array}{l}1.3 \\
1.3 \\
1.3 \\
1.3 \\
1.3\end{array}$ & $\begin{array}{l}1.5 \\
1.5 \\
1.5 \\
1.5 \\
1.5\end{array}$ \\
\hline $\begin{array}{l}21 \ldots \\
22 \ldots \\
23 \ldots \\
24 \ldots \\
25 \ldots\end{array}$ & $\begin{array}{l}2.0 \\
1.9 \\
1.9 \\
1.8 \\
1.8\end{array}$ & $\begin{array}{l}1.6 \\
1.6 \\
4.1 \\
2.8 \\
2.1\end{array}$ & $\begin{array}{l}1.7 \\
1.7 \\
1.6 \\
1.6 \\
1.6\end{array}$ & $\begin{array}{l}1.4 \\
1.4 \\
1.4 \\
1.4 \\
1.4\end{array}$ & $\begin{array}{l}1.2 \\
1.2 \\
1.2 \\
1.2 \\
1.2\end{array}$ & $\begin{array}{l}1.3 \\
1.3 \\
1.3 \\
1.5 \\
1.5\end{array}$ & $\begin{array}{l}1.5 \\
1.5 \\
1.5 \\
1.5 \\
1.5\end{array}$ \\
\hline 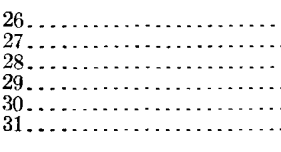 & $\begin{array}{l}1.7 \\
1.7 \\
1.6 \\
1.6 \\
1.6\end{array}$ & $\begin{array}{l}1.9 \\
1.8 \\
1.7 \\
1.6 \\
4.7 \\
1.9\end{array}$ & $\begin{array}{l}.1 .6 \\
1.6 \\
1.6 \\
1.5 \\
1.5 \\
1.5\end{array}$ & $\begin{array}{l}1.4 \\
1.4 \\
1.4 \\
1.4 \\
1.4\end{array}$ & $\begin{array}{l}1.2 \\
1.2 \\
1.1 \\
1.1 \\
1.1 \\
1.1\end{array}$ & $\begin{array}{l}1.5 \\
1.5 \\
1.5 \\
1.5 \\
1.5\end{array}$ & $\begin{array}{l}1.5 \\
1.5 \\
1.5\end{array}$ \\
\hline
\end{tabular}

BEAUCOUP CREEK NEAR PINCKNEYVILLE, ILL.

This station, which is located at the Illinois Central Railroad bridge, $1 \frac{1}{2}$ miles east of Pinckneyville, Ill., was established June 17, 1908 , to collect data for use in studying drainage and flood-control problems.

The drainage area above the station is about 206 square miles.

Gage heights were observed whenever the gage reader happened to be in the vicinity of the gage. Except in a few cases, however, fairly accurate results will be obtained if the missing gage heights will be interpolated.

The following discharge measurement was made:

June 17, 1908: Width, 53 feet; area, 48 square feet; gage height, 2.3 feet; discharge 12 second-feet.

Daily gage height, in feet, of Beaucoup Creek near Pinckneyville, Ill., for 1908.

[R. ('. Huggins, observer.]

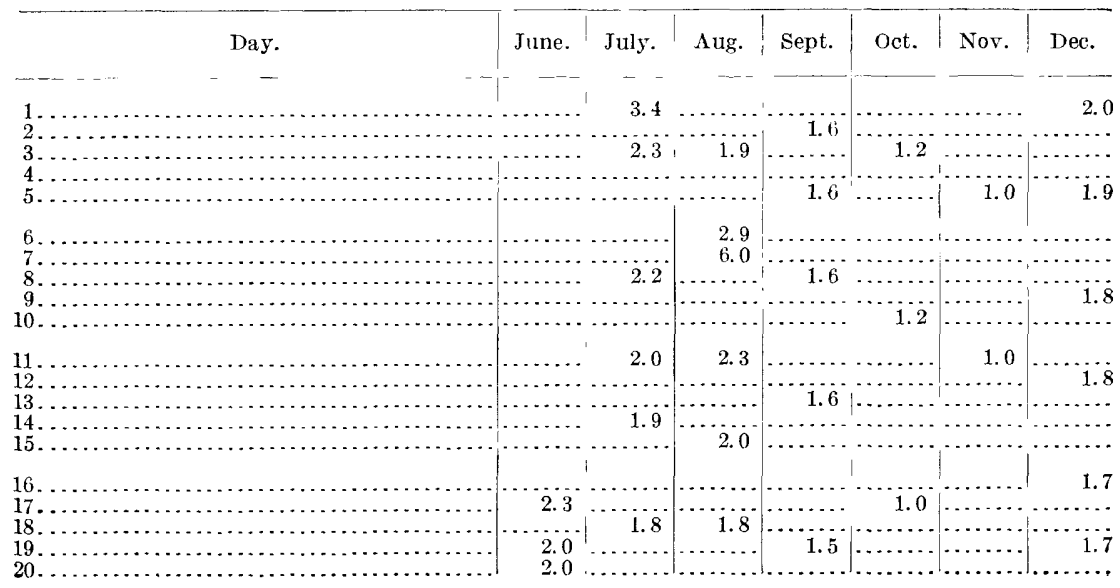


Daily gage height, in feet, of Beaucoup Creek, near Pinckneyville, Ill., for 1908-Con.

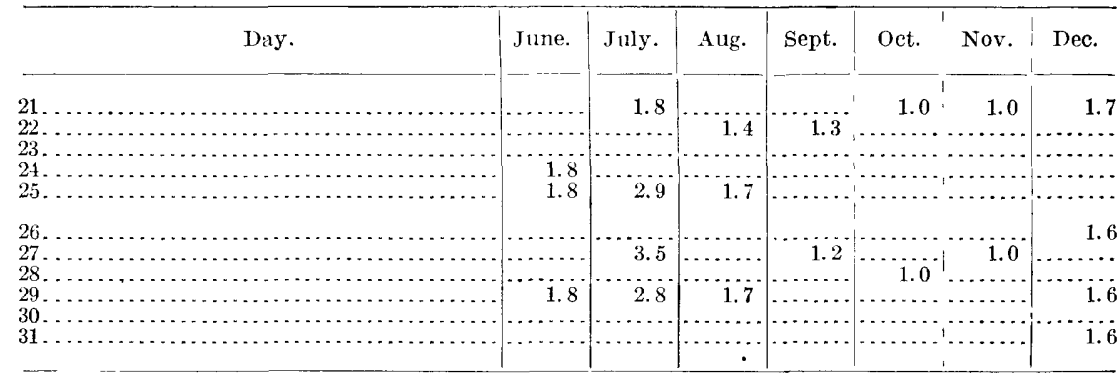

MISCELLANEOUS MEASUREMENTS IN HUDSON BAY AND UPPER MISSISSIPPI RIVER DRAINAGES.

MISCELLANEOUS MEASUREMENTS IN ST. MARY RIVER DRAINAGE BASIN.

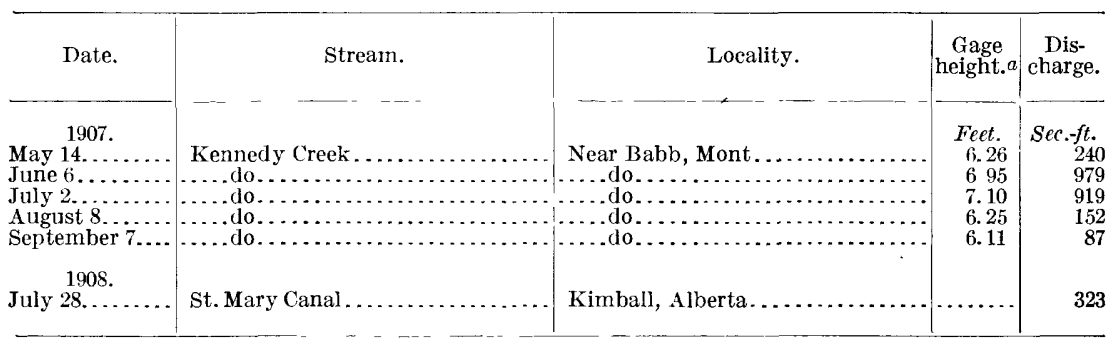

$a$ United States Geological Survey gage used, 1903-1906.

MISCELLANEOUS MEASUREMENTS IN RED RIVER DRAINAGE BASIN.

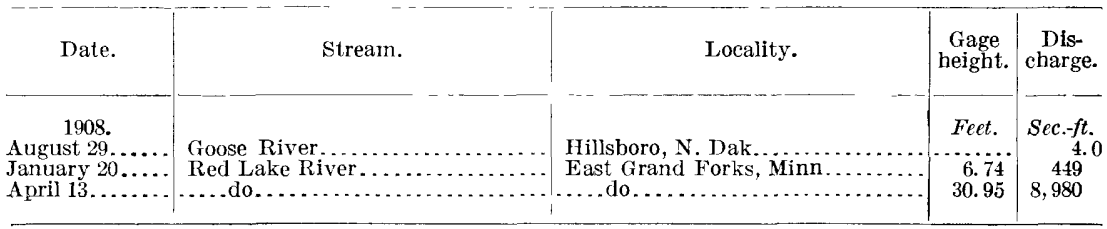

MISCELLANEOUS MEASUREMENT IN WISCONSIN RIVER DRAINAGE BASIN.

The following miscellaneous discharge measurement was made in the Wisconsin River drainage basin March 3, 1908:

Wisconsin River at Kilbourn, Wis.: Gage height, 1.50 feet; discharge, 3,090 second feet; average thickness of ice, 1.1 feet. 
SUMMARY OF MEAN DISCHARGE PER SQUARE MILE.

The following summary of discharge per square mile is given to allow ready comparison of relative rates of run-off from different areas in the upper Mississippi and Hudson Bay drainages.

It shows in a general way the seasonal disiribution of run-off, and the effect of snow, ground, surface, al:d artificial storage. The most important fact worth noting is the almost entire lack of uniformity or agreement between any two stations, which indicates that the discharge of each stream is a law unto itself, and that all projects dependent upon stream flow, if they are to be developed along the safest and most economical limes, must be based on records of stream flow collected with great care over a long series of years as near the location of the project under consideration as possible. 


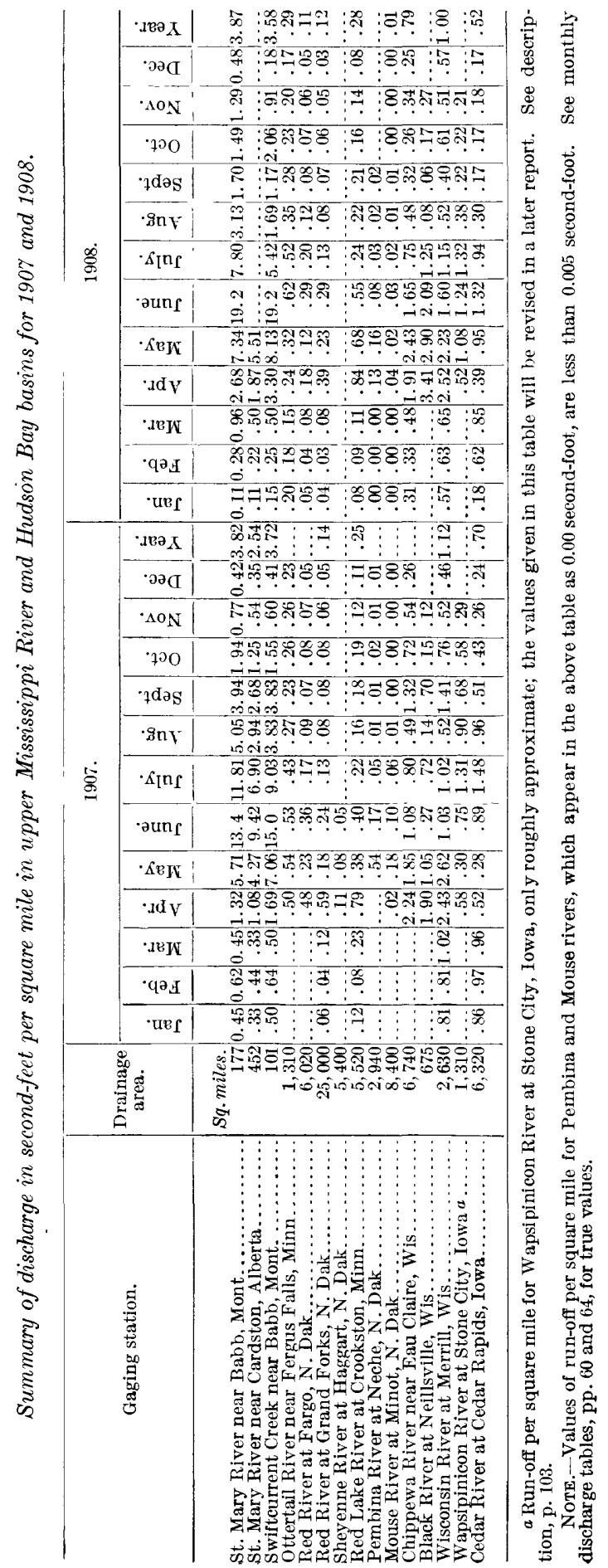




\section{INDEX.}

A.

Accuracy, degree of ..................... 26-27

Acknowledgments to those aiding...........

Acre-foot, definition of.

Anoka, Minn.,

Mississippi Rirer at-

description.

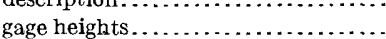

Appropriations, amount of ...............

Arcola, Ill.,

Kaskaskia River near:

description

discharge.......................

gage heights ...........................

Authority for investigations, recital of......

Babb, Mont.,

B.

Kennedy Creek near:

discharge.

St. Mary River near:

deseription..................... 30

discharge...................... 30

discharge, monthly............ 32-33, 128

gage heights.................... 31

rating tables..................... 32

Swifteurrent Creek near:

description....................... 35

discharge....................... $\quad 36$

discharge, monthly.............. 38,128

gage heights .................... 36-37

rating tables..................... $37-38$

Beaucoup Creek near-

Pinckneyville, Ill.:

description.................... 125

discharge...................... 125

gage heights ................... 125-126

Big Muddy River basin:

description..................... 123-124

gaging stations.................. 124

stream fiow................... 124-126

Big Muddy River near-

Cambon, Ill.:

description..................... 124

discharge........................ 124

gage heights.................... 124-125

Black River at-

Black River Falls, Wis.:

dam, view

Neillsville, $W$ is.

description..................... 89

discharge....................... 90

discharge, monthly............. 91, 128

gage heights................... 90-91

rating table..................... 91

$22110-$ IRR $245-10 \longrightarrow 9$
Black River basin: $\quad$ Page.

description.................... 88-89

gaging stations................... 89

river survey.................... 89

stream flow................... 89-91

Black River Falls, dam at, view of........ 30

Bolster, R. H., work of................. 28

Brokaw, Wis.,

Wisconsin River at:

dam, view

C.

Cambon, IIl.,

Big Muddy River near:

description.................... 124

discharge....................... 124

gage heights.................. 124-125

Cardston, Alberta,

St. Mary River near:

description..................... 33

discharge....................... 33

discharge, monthly............... 35, 128

gage heights.................... 34

rating table................... 34

Carlyle, Ill.

Kaskaskia River at:

description....................... 121

discharge...................... 121

gage heights................... 121-122

Cedar Rapids, Iowa,

Cedar River at:

description.................... 108

discharge, monthly............. 110,128

gage heights.................... 109

rating table.................... 110

Cedar River at-

Cedar Rapids, Iowa:

description..................... 108

discharge, monthly.............. 110,128

gage heights.................... 109

rating table..................... 110

Chandler, E. F., work of............... 28

Chandlerville, Ill.,

Sangamon River near:

description..................... 114

discharge........................ 114

gage heights..................... 114

Chippewa Falls, $W$ is.

Chippewa River at:

curves, figure showing.............. 23

description...................... $74-75$

discharge....................... $\quad 75$

discharge, monthly ................ 81-83

gage heights ................... $76-80$

rating tables..................... 81 
Chippewa River at or near-

Chippewa Falls, Wis.:

Page.

curves, figure showing.

description.................... $74-75$

discharge....................... 75

discharge, monthly ................ 81-83

gage heights.................... $76-80$

rating tables.................... 81

Eau Claire, Wis.:

description...................... 83

discharge...................... 83

discharge...................... 85, 128

gage heights.................... 84

rating table..................... 85

Chippewa River basin:

description.................. $72-74$

gaging stations ................... 74

river survey ..................... 74

stream flow.................... $74-88$

Cooperation, credit for................... $\quad 28$

Crookston, Minn.,

Red Lake River at:

description..................... 54

discharge........................ 55

discharge, monthly........... $56-57,128$

gage heights.................... $55-56$

rating table..................... 56

Current meter, description of . ........... 19-20

use of ............................. 18, 20-21

views of .......................... 20

Current-meter stations, views of........... 18

Curves, discharge, flgure showing......... 23

\section{D.}

Definitions, statements of

Devils Lake at-

Devils Lake, N. Dak.

description...

$51-54$

gage heights

53

Discharge, computation of.

$21-26$

curves for ......................... 22

flgure showing.................... 23

measurement of................... 16-21

summary........................ 127-128

Discharge measurements, nature of ........ 15,16

Drainage, stream flow and ................ 9-10

Drainage basins, list of .................. 10

\section{E,}

East Grand Forks, Minn.,

Red Lake River at:

discharge.

Eau Claire River: survey.

Eau Claire, Wis.

Chippewa River near:

description

discharge.

.

rating table....................... 85

Equivalents, list of ..................... 14-15

Evaporation at-

University, N. Dak.
Fargo, N. Dak.,

Red River at:

F.

description.................... 44

discharge........................... 44

discharge, monthly............ 46, 128

gage heights.................... 45

rating table..................... 46

Fergus Falls, Minn.,

Ottertail River near:

description.................... 41-42

discharge................. 42

discharge, monthly.............43,128

gage heights................... 42-43

rating table ...................... 43

Flambeau River:

survey............................. 74

Float method, description of............. 19

Flood prevention, stream flow and ........ 10

Follansbee, Robert, work of .............. 28

G.

Gage heights, nature of................. 15

Gaging station, description of.............. 18

classification of ...................... 22-26

Goose River at-

Hillsboro, .N. Dak.:

discharge......

Grand Forks, N. Dak.,

Fed River at:

description.................... 46-47

discharge....................... 47

discharge, monthly............. 49, 128

gage heights.................... 48

rating table.................... 49

Gray, G. A., work of................... 28

Haggart, N. Dak.,

Sheyenne River at:

description...................... 50

discharge ........................ 50

discharge, monthly............. 51, 128

gage heights.................... 50

rating table.................... 51

Hillsboro, N. Dak.

Goose River at:

discharge...................... 126

Horton, A. H., work of ................... 28

Hoyt, J. C., work of ..................... 28

Huch, A. F., work of ................... 28

Irudson Bay drainage:

description.................. 29

miscellaneous measurements....... 126

stream flow.

$29-67,128$

I.

Ice, measurements under................. 21,26

Illinois, cooperation of................. $\quad 28$

Investigations, authority for.............. 7

purposes of........................ $9-10$

scope of........................... 8-9

Iowa River basin:

description.................. 107-108

gaging stations................. 108

stream flow ..................... 108-110

Irrigation, stream flow and .............. 9 


\section{K.}

Kaskaskia River at or near-

Arcola, Ill.:

deseription...................... 118

discharge..................... 118

gage heights................... 118

Carlyle, Ill.

description.................... 121

discharge...................... 121

gage heights................ 121-122

Shelbyville, Ill:

description................... 118-119

discharge...................... 119

gage heights..................... 119

Vandalia, Ill.:

description . . . . . . . . . . . . . . . 119-120

discharge...................... 120

gage heights................... 120

Kaskaskia River basin:

description.................... 117

gaging stations $. \ldots \ldots \ldots \ldots \ldots \ldots \ldots, 117$

stream flow................... 118-123

Kennedy Creek near-

Babb, Mont.:

discharge...................... 126

Kenney, Ill.,

Salt Creek near:

description....................... 116

discharge...................... 116

gage heights................... 116

Kilbourn, Wis.,

Wisconsin River at:

discharge.

Kimball, Alberta,

St. Mary canal at:

dam, view.

discharge.

Lebanon, Ill.

Silver Creek near:

description...................... 122

discharge.................... 122

gage heights .................. 122-123

\section{M.}

Mathers, J. G., work of

Menominee, Wis.

Red Cedar River at:

description.................... 85-86

discharge $\ldots \ldots \ldots \ldots \ldots \ldots \ldots \ldots \ldots . \quad 86$

discharge, monthly.............. 88

gage heights.................. $86-87$

rating table.................... 87

Merrill, Wis.

Wisconsin River at:

description. .................. 97-98

discharge........................ 98

discharge, monthly.............. 100, 128

gage heights................... 98-99

rating tables.................... 99

Miner's inch, definition of ................ 13

Minot, N. Dak.,

Mouse River at:

description...................6.60 62

discharge.

62
Minot, N. Dak.-Continued.

Mouse River at-Continued. Page. discharge, monthly..............64, 128

gage heights................... $62-63$

rating table...................... 63

Miscellaneous measurements in-

Hudson Bay drainage............ 126

Mississippi River (upper) drainage.. $\quad 126$

Red River basin................... 126

St. Mary River basin............... 126

Wisconsin River basin ............ $\quad 126$

Mississippi River at-

Anoka, Minn.:

description..................... 71

gage heights.................... $71-72$

Mississippi River (upper) drainage:

description . ................... $68-70$

gaging stations .................. 70

miscellaneous measurements........ $\quad 126$

stream flow..................... 71-128

Monticello, Ill.

Sangamon River at:

description...................... 112

discharge....................... $\quad 112$

gage heights.................... 112

Mouse River at-

Minot, N. Dak.

description. ................... $60-62$

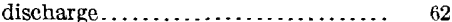

discharge, monthly .............. 64, 128

gage heights................... $62-63$

rating table...................... 63

N.

Navigation, stream flow and..............

Necedah, Wis.

Wisconsin River near:

description.................... 100

discharge....................... 101

gage heights................ 101-102

Neche, N. Dak.

Pembina River at:

description.................... 57

discharge....................... 58

discharge, monthly.............60, 128

gage heights.................... 58-59

rating tables.................... 59

Neillsville, Wis.,

Black River at:

description .................... 89

discharge....................... 90

discharge, monthly............. 91,128

gage heights.................... $90-91$

rating table.................... 91

\section{o.}

O'Neill, W. M., work of................. 28

ottertail River near-

Fergus Falls, Minn.:

description. .................... 41-42

discharge...................... 42

discharge, monthly ............ 43,128

gage heights..................... 42-43

rating table................... 43 
P.

Page.

Padgett, H. D., work of................ 28

Pembina River at-

Neche, N. Dak.:

description...................... 57

discharge...................... 58

discharge, monthly ............. 60,128

gage heights................. 58-59

rating tables...................... 59

Plerson, J. B., work of................. 28

Pinckneyville, Ill.,

Beaucoup Creek near:

description.................... 125

discharge........................ 125

gage heights................. 125-126

Price current meters, views of ............ 20

Publications, lists of.................... 10-13

Rainfall at-

R.

University, N. Dak...............66-67

Rating curves, construction and use of..... 22

Rating tables, construction of............. 22

nature of ........................... 16

Red Cedar River at-

Menominee, Wis.:

description.

discharge, monthly..... 88

gage heights................... 86-87

rating table..................... 87

Red Lake River at-

Crookston, Minn.:

description....................... 54

discharge...................... 55

discharge, monthly.......... 56-57, 128

gage heights ..................... 55-56

rating table.................... 56

East Grand Forks, Minn.:

discharge.

Red River at-

Fargo, N. Dak.:

description.................... 44

discharge....................... 44

discharge, monthly............ 46,128

gage heights .................... 46

rating table.................... 46

Grand Forks, N. Dak.:

description...................... 46-47

discharge...................... 47

discharge, monthly............. 49,128

gage heights.................... 48

rating table.................... 49

Red River basin:

description................... 38-41

evaporation, rainfall, etc.......... . 64-67

gaging stations.................. 41

miscellaneous measurements........ 126

stream flow ..................... 41-64

Revision, need for .................... 27-28

Rhinelander, Wis.,

Wisconsin River near:

description................... 94-95

discharge..................... 95

discharge, monthly .............. 97

gage heights .................... 95-96

rating table..................... 96
River surveys. See Surveys.

Riverton, IIl.

Sangamon River at:

description..................... 113

discharge...................... 113

gage heights................... 113

Rock River at-

Rockton, Ill.:

description..................... 105

discharge........................ 105

gage heights................... 106

Rock River basin:

description.................... 103-105

gaging stations.................. 105

stream flow................... 105-106

Rockton, 1ll.,

Rock River at:

description..................... 105

discharge..................... 105

gage heights.................... 106

Run-off, computation of................ 21-26

definition of ....................... 13

s.

St. Croix Falls, Wis., dam, et»., at, view of... 70

St. Mary canal at-

Kimball, Alberta:

dam, view...................... 30

discharge...................... 126

St. Mary River basin:

description ..................... 29-30

gaging stations.................. 30

miscellaneous measurements....... 126

stream fiow................ 30-38, 128

St. Mary River near-

Babb, Mont.:

description. .................... 30

discharge....................... 30

discharge, monthly.................... $32-33,128$

gage heights.................. 31

rating tables..................... 32

Cardston, Alberta:

description.................... 33

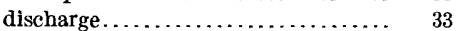

discharge, monthly............ 35, 128

gage heights................... 34

rating table...................... 34

Salt Creek near-

Kenney, Ill.:

description................... $\quad 116$

discharge...................... 116

gage heights.................. 116

Sangamon River at or near-

Chandlerville, Ill.:

description.................... 114

discharge...................... 114

gage heights.................. 114

Monticello, Ill:

description................... 112

discharge...................... 112

gage heights................... $\quad 112$

Riverton, Ill.

description................... 113

discharge....................... 113

gage heights................... 113 
Sangamon River basin:

description.

Page.

gaging stations.

110-111

stream flow.

$12-116$

Sangamon River (South Fork) near-

Taylorville, Ill.:

description................... 115

discharge ....................... 115

gage heights.................... 115

Second-feet per square mile, deflnition of.... 13

Second-foot, deflnition of................. 13

Section, changes in, estimation for......... 23-25

Shelbyville, III.,

Kaskaskia River at:

description.

discharge.

gage heights

Sheyenne River at-

Haggart, N. Dak.:

description $\ldots \ldots \ldots \ldots \ldots \ldots \ldots \ldots, \quad 50$

discharge...................... 50

discharge, monthly ............. 51,128

gage heights.................... 50

rating table..................... 51

Silver Creek near-

Lebanon, Ill.:

description..................... 122

discharge ....................... 122

gage heights.................. 122-123

Slope method, description of .............. 16

Smith, L. S., work of.................. 28

Stevens, G. C., work of................... 28

Stewart, J. E., work of.................. 28

Stream measurements, accuracy of ........ 26-27

data of, use of .................... 27-28

methods of ....................... 16-21

Stone City, Iowa

Wapsipinicon River at:

description................... 103

discharge, monthly............. 128

Summary of discharge in-

Hudson Bay drainage............ 127-128

Mississippi River (upper) drainage. 127-128

Surveys on-

Black River..................... 89

Eau Claire River.................

Flambeau River.................. 74

Wisconsin River................ 94

Swamps, drainage of, stream flow and...... . 9-10

Swiftcurrent Creek near-

Babb, Mont.

description.................... 35

discharge...................... 36

discharge, monthly............ 38, 128

gage heights.................... $36-37$

rating tables................... $37-38$

T.

Tables, explanation of.

15-16

Taylor, R. J., work of .

Taylorville, Ill,

Sangamon River (South Fork) near:

description

discharge. . .

gage heights.
Temperature at-

Page.

University, N. Dak.

$66-67$

\section{U.}

University, N. Dak.:

evaporation .................. 64-67

rainfall ............... $66-67$

temperature................... 66-67

Upper Mississippi. See Mississippi River (upper).

V.

Vandalia, IIl.-

Kaskaskia River at:

description................... 119-120

discharge...................... 120

gage heights.................... 120

Velocity method, description of.......... 17-21

W.

Walters, M. I., work of

Wapsipinicon River at-

Stone City, Iowa:

description..................... 103

discharge, monthly.............. 128

Wapsipinicon River basin :

description................... 102-103

gaging stations................. 103

stream flow . ..................... 103

Water power, stream flow and............. 9

Water supply, stream flow and........... 9

Weir method, description of ............. 16-17

Wisconsin River: survey........................ 94

Wisconsin River at or near-

Brokaw, Wis.:

dam, view................. 94

Kilbourn, Wis. :

discharge....................... $\quad 126$

Merrill, Wis.:

description.................... 97-98

discharge........................ 98

discharge, monthly ............ 100, 128

gage heights.................... 98-99

rating tables.................... 99

Necedah, $W$ is. :

description..................... 100

discharge..................... 101

gage heights .................. 101-102

Rhinelander, Wis.:

description ................... 94-95

discharge...................... 95

discharge, monthly.............. 97

gage heights.................... 95 96

rating table..................... 96

Wisconsin River basin:

description..................... 92-94

gaging stations................... 94

miscellaneous measurement........ 126

river surveys.................... 94

stream flow ................... 94-102

wood, B. D., work of.................. 28

Work, division of...................... 28 